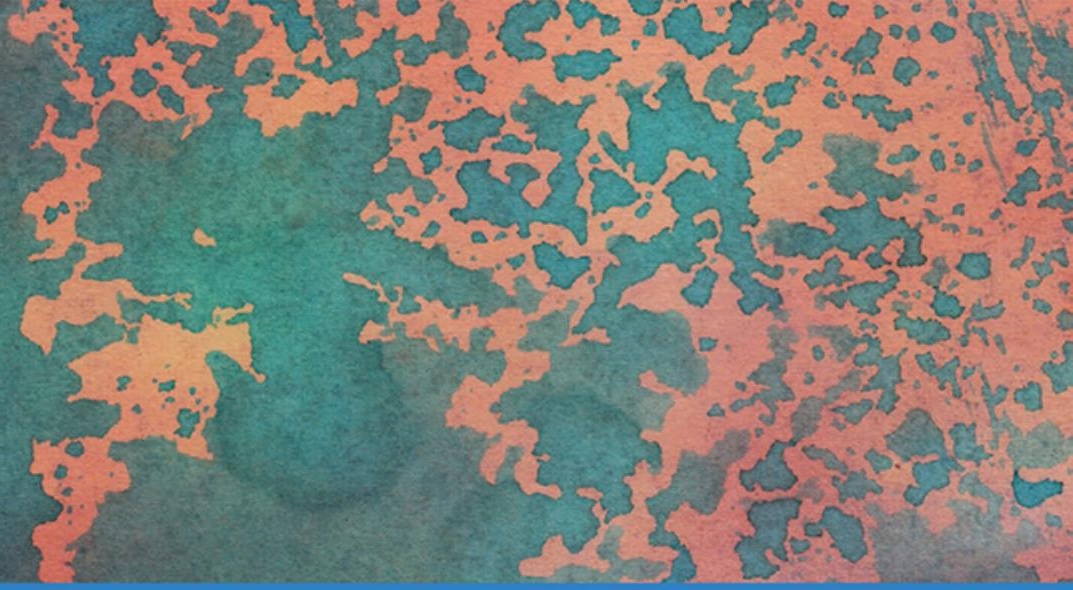

Studies in Migration and Diaspora

\title{
REFUGEES AND KNOWLEDGE PRODUCTION
}

EUROPE'S PAST AND PRESENT

\author{
Edited by
}

Magdalena Kmak and Heta Björklund
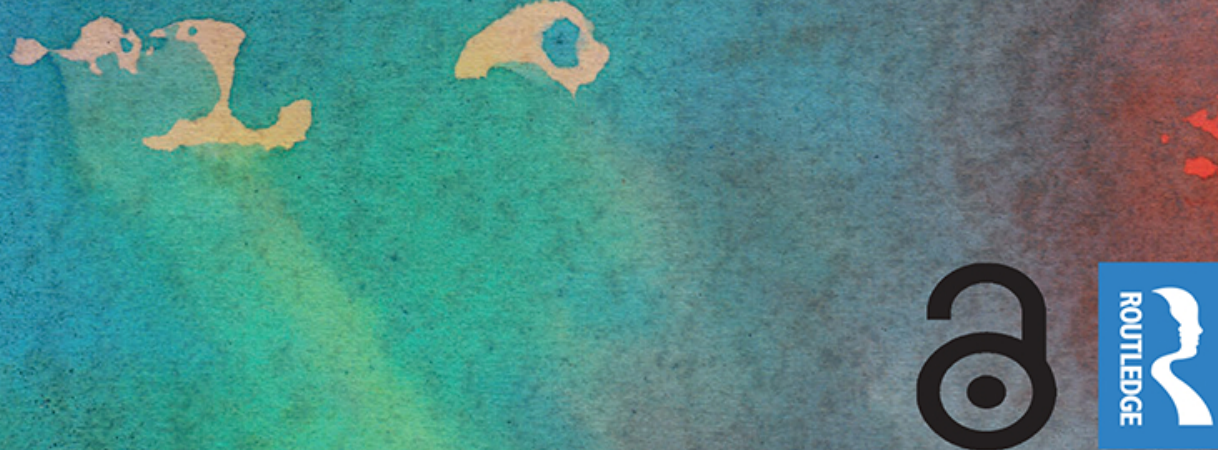


\section{Refugees and Knowledge Production}

Building on research within the fields of exile studies and critical migration studies and drawing links between historical and contemporary 'refugee scholarship', this volume challenges the bias of methodological nationalism and Eurocentrism in discussing the multifaceted forms of knowledge emerging in the context of migration and mobility. With critical attention to the meaning, production and scope of 'refugee scholarship' generated at the institutions of higher education, it also focuses on 'refugee knowledge' produced outside academia, and scrutinizes the conditions according to which it is validated or silenced. Presenting studies of historical refuge and exile, together with the experiences of contemporary refugee scholars, this book will appeal to scholars across the social sciences with interests in forced migration, refugee studies, the sociology of knowledge and the phenomenon of 'insider' knowledge, and research methods and methodology.

Magdalena Kmak is a Professor of International Law with specialization in migration and minority research at Åbo Akademi University, Finland and a researcher at the University of Helsinki.

Heta Björklund has a PhD in Classics from the University of Helsinki, Finland. She has previously worked as an editor at the Classical journal Arctos and is the co-editor of Roman Law and the Idea of Europe. 


\section{Studies in Migration and Diaspora}

Series Editor: Anne J. Kershen

Queen Mary University of London, UK

Studies in Migration and Diaspora is a series designed to showcase the interdisciplinary and multidisciplinary nature of research in this important field. Volumes in the series cover local, national and global issues and engage with both historical and contemporary events. The books will appeal to scholars, students and all those engaged in the study of migration and diaspora. Amongst the topics covered are minority ethnic relations, transnational movements and the cultural, social and political implications of moving from 'over there', to 'over here'.

\section{Higher Education and Social Mobility in France}

Challenges and Possibilities among Descendants of North African Immigrants Shirin Shahrokni

Migrant Mothers in the Digital Age

Emotion and Belonging in Migrant Maternal Online Communities Leah Williams Veazey

Political Dissent and Democratic Remittances

The Activities of Russian Migrants in Europe

Joanna Fomina

Rethinking Privilege and Social Mobility in Middle-Class Migration

Migrants 'In-Between'

Edited by Shanthi Robertson and Rosie Roberts

Refugees and Knowledge Production

Europe's Past and Present

Magdalena Kmak and Heta Björklund

For more information about this series, please visit: https://www.routledge. com/sociology/series/ASHSER1049 


\section{Refugees and Knowledge Production}

Europe's Past and Present

\section{Edited by Magdalena Kmak and Heta Björklund}


First published 2022

by Routledge

4 Park Square, Milton Park, Abingdon, Oxon OX14 4RN

and by Routledge

605 Third Avenue, New York, NY 10158

Routledge is an imprint of the Taylor \& Francis Group, an informa business

(C) 2022 selection and editorial matter, Magdalena Kmak and Heta Björklund; individual chapters, the contributors

The right of Magdalena Kmak and Heta Björklund to be identified as the authors of the editorial material, and of the authors for their individual chapters, has been asserted in accordance with sections 77 and 78 of the Copyright, Designs and Patents Act 1988.

The Open Access version of this book, available at www.taylorfrancis. com, has been made available under a Creative Commons Attribution-Non Commercial-No Derivatives 4.0 license

Trademark notice: Product or corporate names may be trademarks or registered trademarks, and are used only for identification and explanation without intent to infringe.

British Library Cataloguing-in-Publication Data

A catalogue record for this book is available from the British Library

Library of Congress Cataloging-in-Publication Data

A catalog record has been requested for this book

ISBN: 978-0-367-55206-0 (hbk)

ISBN: 978-0-367-55207-7 (pbk)

ISBN: 978-1-003-09242-1 (ebk)

DOI: $10.4324 / 9781003092421$

Typeset in Times New Roman

by SPi Technologies India Pvt Ltd (Straive) 


\section{Contents}

Notes on Contributors vii

List of Illustrations $\quad$ ix

Acknowledgements $\quad \mathrm{x}$

Series Editor's Preface xi

Introduction 1

MAGDALENA KMAK AND HETA BJÖRKLUND

\section{PART I}

Beyond Methodological and Eurocentric Nationalism in Research on Scholarship

1 Methodological nationalism and migration studies: historical and contemporary perspectives

PEDRO T. MAGALHÃES AND LAURA SUMARI

2 Refugee and migrant knowledge as historical narratives PREM KUMAR RAJARAM

3 Narratives on 'refugee knowledge' in the institutions of Europe BEA BERGHOLM AND REETTA TOIVANEN

4 The world as an exiling political structure: Yassin al-Haj

Saleh's conceptualisation of exile 
vi Contents

\section{PART II}

Refugee Scholarship and Scholarly Identity

5 Exile and emigration from the Third Reich: Stages and results of research in Germany

ALFONS SÖLLNER

6 Personal and academic narratives of exiled and displaced scholars

MAGDALENA KMAK AND MEHRNOOSH FARZAMFAR

7 Refugee scholars then and now

CAROL BOHMER

8 Beyond authoritarianism: migration, uncertainty and a sense of belonging among public intellectuals

CHRISTIAN FRANKLIN SVENSSON

\section{PART III}

\section{Silencing and Gatekeeping Knowledges}

9 The silenced majority: academic refugees and the vicissitudes of readaptation

KAIUS TUORI

10 Reframing the subject: affective knowledge in the urgency of refuge

ALI ALI

11 Nursing trauma, harvesting data: refugee knowledge and refugee labour in the international humanitarian regime 


\section{Notes on Contributors}

Ali Ali is a $\mathrm{PhD}$ candidate (in Gender, Culture and Society) and a researcher at EuroStorie, University of Helsinki, Finland.

Bea Bergholm is a Master of Social Sciences from the University of Helsinki, Finland with a background in social and cultural anthropology.

Heta Björklund has a PhD in Classics from the University of Helsinki. She has previously worked as an editor at the Classical journal Arctos and is the co-editor of Roman Law and the Idea of Europe.

Carol Bohmer is a Visiting Senior Research fellow at King's College London, UK and a Visiting Scholar in the Department of Government, Dartmouth College, Hanover NH, USA.

ElSayed Mahmoud EISehamy is a $\mathrm{PhD}$ candidate in Social Anthropology at the University of Manchester. His doctoral project examines political subjectivity formation of Egyptian exiles in Istanbul in the aftermath of the 2013 military coup in Egypt. ElSayed has been a fellow researcher at The Aleppo Project, School of Public Policy at Central European University in Budapest. He has background in Sociology and Anthropology and his research interests include exile, militarization, state configurations, and counter-revolutions in the Arab world.

Mehrnoosh Farzamfar is a postdoctoral researcher at the Faculty of Law, University of Turku. She currently analyses the implications of public health emergencies upon fundamental rights. In her doctoral dissertation, she studied the tension between asylum law and national security.

Nadine Hassouneh is a Postdoctoral Research Fellow at the University of Leeds and an Honorary Fellow at the Council for British Research in the Levant - British Institute in Amman. She previously worked as a conflict and context analyst at INGOs responding to the Syrian crisis in Jordan and Lebanon.

Magdalena Kmak is a Professor of Public International Law with specialisation in migration and minority research at Åbo Akademi University, Finland and a researcher at the University of Helsinki. 
Pedro T. Magalhães is a Professor of Political Science at the University of Minho, Portugal. His research focuses on democratic theory and the history of twentieth-century political thought.

Elisa Pascucci is a post-doctoral researcher at the University of Helsinki, Finland. She is a human geographer whose research focuses on refugee and migrant political agency, spaces and infrastructures of refuge and humanitarian aid, and qualitative research methods.

Prem Kumar Rajaram is a Professor of Sociology and Social Anthropology at Central European University, Budapest. His work centres on the study of forced migration and displacement, on capitalism and on inequalities in higher education.

Alfons Sölner is a Professor Emeritus of Political Theory and History of Ideas (Politische Theorie und Ideengeschichte) at Technische Universität Chemnitz, Germany.

Laura Sumari is a PhD student at the University of Helsinki, Finland. Her main themes of interests include mobilities, security and postcolonial theory, and in her doctoral dissertation she examines refugee narratives of Europe from a human security perspective.

Christian Franklin Svensson is an Associate Professor at the Department of Sociology and Social Work, Aalborg University, Denmark. As an anthropologist, his research and writing deal with issues of migration, civil society, social movements, freedom of speech, self-organisation, social identity and culture.

Reetta Toivanen is a Professor of Sustainability Science (indigenous sustainabilities) at the Institute of Sustainability Science (HELSUS) and at the Department of Cultures at the University of Helsinki and a docent in social and cultural anthropology at the Universities of Helsinki and Eastern Finland.

Kaius Tuori is Professor for European Intellectual History at the University of Helsinki, Finland. He is a scholar of legal history involved in research projects on the understanding of tradition, culture, identity, memory and the uses of the past. 


\section{Illustrations}

4.1 Yassin al-Haj Saleh. Image by Yassin Swehat, February 2021. 


\section{Acknowledgements}

This book originally grew from the presentations and discussions at the "Coming Home: The Post-war Return of Refugee Scholarship" conference held at the University of Helsinki in April 2019. We are particularly grateful to Prosper Maguchu (Free University Amsterdam), Richard Ned Lebow (King's College London), and Alfons Söllner (TU Chemnitz), as well as to Ali Ali, Mehrnoosh Farzamfar, Elisa Pascucci, and Reetta Toivanen at the University of Helsinki, for their insights at the conference roundtable discussion and the inspiration to take on the work on this volume.

Special thanks go to all of the book contributors not only for their excellent chapters but also for providing comments and insights on each other's texts, which shaped the book into its final form.

We want to thank the entire Centre of Excellence in Law, Identity and the European Narratives (EuroStorie) and the Centre for European Studies at the University of Helsinki for their support and collaboration. Special thanks go to Maria Erma, Nora Fabritius, Noora Hakkarainen, Tuomas Heikkilä, Sara Heinonen, Iida Karjalainen, Mervi Leppäkorpi, Senni Mut-Tracy, Marianne Sandelin, Karla Schröter, and Iida Silfverhuth.

We are also grateful for the work of Christopher Goddard, Mark Shackleton, and Kate Sotejeff-Wilson on proof-reading this volume.

We would like to thank Neil Jordan and Alice Salt at Routledge, as well as the anonymous reviewers for their valuable feedback on this volume.

This work has been supported by the Academy of Finland-funded Centre of Excellence in Law, Identity and the European Narratives (EuroStorie), funding decision numbers 312154, 336676, 312431 and 336678. 


\section{Series Editor's Preface}

At the end of 2020 there were a recorded 26.4 million refugees globally, half of whom under the age of 18 . If the number of those who have been displaced is added, the total amounts to a disturbing 84.4 million. ${ }^{1}$

Refugees cover the spectrum of genders, ages and abilities. Some will have had the benefit of a high level of education; others will have had little or no schooling. Some will have sought sanctuary in the hope that they can further their professional or scholarly careers; others see refuge as the first step up the ladder to a better, more secure, life. The refugees who are at the core of this book fall into the first category: individuals who left their native countries to escape persecution, war, natural disasters or forced displacement, carrying with them the cultural capital of scholarship in a variety of fields. To put this in perspective, the editors of this volume reveal that, since 2011, there have been 1,600 attacks on scholars in more than one hundred countries.

It is not just the ported knowledge and skills that the contributors to this book are focused on. Their challenge is to identify and analyse what the experience of displacement, mobility and exile have contributed to, or taken from, the subjects of their study and, additionally, to identify the way in which the impact of the precarity that becomes a part of the existence of all but the most fortunate few, further affects work and lives.

Whilst it is acknowledged that refugees have contributed to scholarship and the arts for centuries, the essays in this volume cover a temporal span from the great exodus from Nazi Germany in the 1930s to recent times. From these we learn that the lessons of the earlier period, as the figures above prove, have not been learned by all and, as the studies in this book illustrate, though three generations have passed and the lives and the creativity of the refugees may vary, there are similarities as well as differences in the experiences of those in exile. In addition, the reader will discover that not all those who managed to find sanctuary remain in their place of refuge. There are those who, once it was safe, returned to their original points of departure, for example, those who went back to Germany after the Second World War, and subsequently made impressive contributions to the worlds of academe and science as a result of combining their original scholarship with the newfound experiences of mobility, exile and work gained whilst in refuge. 
However, not all refugee scholars are readily accepted. Whilst 'the stars' may be awarded positions in leading academies, some suffer short-term contracts or the ignominy of employment as unskilled workers. Others, even some of the more successful, select a mobile existence, developing nomadic de-nationalized identities, ones which may seem attractive and free from the ties of the nation-state, but which bring with them, as is suggested by certain contributors, a form of grief which adds to the knowledge and experience of the exiled - even if returned - refugee scholar. It is a point worth noting, as the chapters in the book highlight, that the non-European refugee, even the non-European refugee scholar, has all too often found it much harder to gain a foothold in the North American and European world of academe.

The essays in this book are ground-breaking and thought-provoking. The contributors, by placing the past and the more recent experiences of scholarly refugees and the acquisition of their refugee knowledge under the microscope, are opening up new avenues of exploration into the migrant experience, particularly into the incorporation of the knowledge gained in mobility into post-refugee works. The chapters ask the reader to consider not only the acquisition and promotion of refugee knowledge but also the experiences of belonging and non-belonging and the self-awareness of who they are, where they belong and where they are going, as scholars, refugees and as individuals. It is to be hoped that this volume will encourage others to explore more deeply the works and emotions of those who have used their experiences of displacement, refuge and mobility to further their productivity in the worlds of academe, the sciences and the arts.

Anne J. Kershen

Queen Mary University of London

Winter 2022

\section{Note}

1 UNHCR.org/refugee-statistics accessed 23/9/21. 


\title{
Introduction
}

\author{
Magdalena Kmak and Heta Björklund
}

It is a truism to say that scientific knowledge does not suddenly emerge from the dust of scholars' offices but is always shaped by their worldviews, values and beliefs, which are also shared by other members of the scientific community ${ }^{1}$ operating in a particular historical milieu. ${ }^{2}$ It is perhaps less often discussed, however, that knowledge is also affected by scholars' own individual experiences, incidents, stories and emotions that give meaning to their scientific expression. As Hannah Arendt wrote, "thought itself - (...)-arises out of the actuality of incident, and incidents of living experience must remain its guideposts by which it takes its bearing if it is not to lose itself". 3

The main focus of this book is knowledge created in the context of mobility and displacement - the circumstances that generate new communities, experiences and stories affecting the processes of knowledge production. But the book's aim is not solely to trace and account for the concrete forms of knowledge created through different types of movement. We are not interested in the hypermobility of contemporary western scholars (the authors of this book included) who, until the outbreak of the Covid-19 pandemic, have been privileged in their ability to attend numerous conferences and meetings around the globe every year. Instead, while looking at mobile knowledges this book is particularly interested in knowledges created in and through forced displacement and exile. By asking what is the epistemological value of mobility and displacement for scientific knowledge we shift the perspective from the static, institutionalized settings of knowledge production to mobile and therefore minoritarian forms of knowledge formed through the experiences of movement. As Asli Vatansever describes, displacement is an experience creating "a particularly paradoxical moment for subjectivity, that alters one's existential conditions as well as one's way of viewing the world and the self". ${ }^{4}$ At the same time, displacement also challenges the primacy of the established forms of political, social or scientific membership. ${ }^{5}$ It provides alternative knowledge of societies that is rooted in mobility and, as underlined by Thomas Nail, allow us to understand movement and mobility, as well as those who are on the move, as a socially constitutive power. ${ }^{6}$ The shift towards the figure of the 'displaced scholar' as well as the non-academic mobile knowledge producer that this book attempts to make, also shows displacement, following Vatansever, as "a significant stage in the process of precarization", ${ }^{7}$ bringing

DOI: $10.4324 / 9781003092421-1$ 
to the fore non-dominant and precarious knowledges, 'failed' academic careers, and accounts of lives lost in the context of forced displacement.

On a more general level, therefore, the shift in perspective from static to mobile conditions of knowledge production allows us not only to account for the knowledges produced through the experience of displacement, but also, to understand better the structural margins of contemporary institutional academia ${ }^{8}$ with its gatekeeping practices, precarity of academic work and the societal role of researchers and lecturers. With the addition of the decolonial lens this shift also allows us, as Lucy Mayblin and Joe Turner underline, to ask in particular: "where authoritative and influential knowledge is produced and proliferated, which knowledges are produced by which people, and which languages and media hold legitimacy and have greater global reach" and, finally, who is excluded from participation in this knowledge creation. ${ }^{9}$

This book originally arose from a roundtable discussion at the "Coming Home: The Post-war Return of Refugee Scholarship" conference, held in April 2019 at the University of Helsinki, organized by the Centre of Excellence in Law, Identity and the European Narratives. ${ }^{10}$ We asked the panellists of the roundtable - scholars who are refugees themselves or who focus in their research on knowledges created by refugees and migrants - to reflect on their understanding of the meaning of home and its importance for their research, the impact of the experience of displacement on their scholarship or the scholarship of those scholars that they knew or studied, and the meaning of refugee or exile scholarship. The roundtable discussion focused on the links between the reason for fleeing and the topic of one's studies, the role of language, the adaptation strategies or the general situation in contemporary academia. One emerging theme was also the essentializing quality of the used concepts such as an exile, émigré or a refugee and the way Europe is being narrated through 'refugee knowledges'.

While the roundtable discussion served as an intellectual point of departure for the analysis of the meaning of 'refugee scholarship', this book emerges from a background of scholarly discussion within exile studies and critical migration studies, and draws links between historical and contemporary scholarship.

The aim of this edited volume is to open up, problematize and contextualize the concepts of 'refugee scholarship' and, more broadly, 'refugee knowledge' in and of contemporary and historical Europe. Even though scientific knowledge is a primary focus of the volume, the meaning, production and scope of 'refugee scholarship', generated at the institutions of higher education, is critically discussed. At the same time, this volume focuses on the 'refugee knowledge' produced outside of these institutions and scrutinizes conditions of their validation or silencing. The contributors are scholars of various disciplines, with both personal and scholarly interest in 'refugee knowledges' and 'refugee scholarship', and are differently positioned within the contemporary academia.

\section{Mobility as a mode of knowing}

As one of the most famous exile intellectuals, Edward Said wrote in his Reflections on Exile, 
[m]odern Western culture is in large part the work of exiles, émigrés, refugees. In the United States, academic, intellectual and aesthetic thought is what it is today because of refugees from fascism, communism, and other regimes given to the oppression and expulsion of dissidents. ${ }^{11}$

To be sure, mobility as a mode of knowing or the production of knowledge through mobility is not a new field of study. The movement or circulation of human beings has been recognized as a necessary element of the transfer of valuable knowledge. In particular, the role of exiled scholars or intellectuals in creating a new scientific knowledge has been widely recognized. As Peter Burke underlines, historically the movement of scholars across borders had tremendous intellectual consequences. ${ }^{12}$ Certainly, scholars fleeing political and religious persecutions contributed to the creation of new knowledges through deprovincialization of their own knowledge, mediation between cultures, distanciation and outsiderness in relation to dominant cultures and the hybridization of traditions. ${ }^{13}$ Whereas the contribution of exile or displaced scholars to the production of knowledge is a global topic ${ }^{14}$ and the impact of many groups of scholars such as French Huguenots or the Russian Diaspora have been well documented, ${ }^{15}$ the theoretical and methodological point of departure for this book is the scholarship developed in the wake of the Great Exodus from Nazi Germany. During the 1930s as many as 2,000 scholars were dismissed from German universities and $60 \%$ of them went into exile. ${ }^{16}$ Those who found positions abroad, mostly at universities in the USA or the UK, contributed to research, scientific discoveries or developments of new scientific disciplines. They often brought this new knowledge, in various forms, back home, ${ }^{17}$ influencing political culture and academic research. ${ }^{18}$ For instance, according to Kaius Tuori, the experience of exile and immersion in a new academic culture by a group of German-Jewish scholars of Roman law in the 1930s and 1940s contributed significantly to the development of the idea of the shared European legal culture. ${ }^{19}$

The aim of this book, however, is to expand the knowledge of refugee scholarship beyond this framework of exile studies and to incorporate other epistemological approaches to exile and displacement that are relevant to Europe today. This includes both the novel methodological approaches, experiences produced outside Europe, as well as contemporary epistemologies of exile and displacement. Nowadays, the number of scholars in displacement remains very high. Since 2011, the Scholars at Risk (SAR) network of universities, which supports displaced scholars, has reported over 1,600 attacks on higher education in over one hundred countries, ${ }^{20}$ leading to increased displacement of academics. One example among many are Academics for Peace from Turkey, whose displacement was a follow-up of a petition against the Turkish state military offensive in the Kurdish-populated areas of Turkey. The Peace Petition signed in 2016 by 1,128 scholars was followed by purges, sackings and court trials and many of the signatories had to leave the country. Overall, since the funding of the SAR of universities in 2000, it has arranged more than 1,200 positions for scholars seeking assistance. Even though the 
conditions for academic work have changed since the 1930s and the field of scientific research is one of the most globalized nowadays, displaced scholars still struggle to continue their scientific work in new environments.

The impact of the experience of displacement on scholarly changes has been accounted for in the literature, both in the first and the second generation of exile studies, ${ }^{21}$ which focused primarily on biographical accounts and the impact the émigrés had in their countries of displacement. The impact of exile scholarship as well as the discipline of exile studies has, however, also affected the countries of origins of these scholars. As Alfons Söllner writes in this volume, through the discipline of Exilforschung, exile and emigration became part of the historical consciousness in post-war Germany, also coshaping, perhaps unconsciously, current German asylum policies (chapter 5). Building on this vast area of knowledge, this volume constitutes an attempt to contribute to the emerging third generation of exile studies, with the focus on the impact of exile experience on combining previously unrelated ideas and the production of new theories. ${ }^{22}$ This new focus on academic displacement not only brings forward the agency of the émigrés ${ }^{23}$ and recognizes the role of affects and emotions in the process of knowledge production, ${ }^{24}$ but also encompasses the expanding research field of knowledges produced outside Europe and the epistemologies of contemporary migration.

Scholars and intellectuals have often been considered to be those who, more often than other refugees, reflect on their exile or displacement as a condition of general political or cultural significance. While some refused (for various reasons) to be called exiled intellectuals, ${ }^{25}$ others recognized the impact of exile or migration experience on their academic work and their thoughts. Many understood that they would not have accomplished as much as they did if they had remained in their home countries. Among GermanJewish scholars, for instance, the theologian Paul Tillich reflected in one of his lectures on how exile in the USA had deprovincialized him and his thoughts. ${ }^{26}$ Another well-known example is Hannah Arendt, whose extensive writings about exile, political justice, and human rights continue to influence the way we think about society and politics, or Palestinian intellectuals such as Edward Said and Munir Fasheh, ${ }^{27}$ who have had a significant influence on global intellectual movements.

In her recent book, At the Margins of Academia, Aslı Vatansever gives an account of the impact and experience of displacement on the group of Academics for Peace in Germany providing social and political commentary about displacement and knowledge production, the impact of displacement and precarity on subjectivity and the condition of contemporary academia. Another example is the account of the writings about exile by Syrian writer and scholar Yassin al-Haj Saleh in the chapter by ElSayed Mahmoud ElSehamy in this volume. In his writings, al-Haj Saleh articulates the phenomenon of exile beyond its personified, literary and figurative aesthetics. Exile for him is not exclusively about displacement and uprooting; instead, exilement, as a cluster of practices and forces, is a modality of government which is constitutive of the Assadist regime's rule in Syria. It is also 
important to remember, however, that many scholars remained for various reasons silent about their own experiences. In her book Edgar and Brigitte, Rosemary Bodenheimer writes about her mother, Brigitte Bodenheimer: "she was being true to her nature and training: one did not complain about one's status as a woman or a Jew, nor did one draw on the vocabulary of victimization". ${ }^{28}$ Another exiled lawyer, Otto Kirchheimer, was also very silent about his personal exile experiences, possibly channelling his personal experiences into an extensive chapter on the history and present situation of political asylum in his influential work Political Justice. ${ }^{29}$

The aim of this book, however, is to go beyond simple comparisons between the experiences of historical and contemporary figures. As Kmak and Farzamfar show in this volume, the difference between historical and contemporary narratives lies in the situatedness of historical and contemporary experiences which, even though sometimes surprisingly similar (like complaints about the inability to conduct research due to the increasing number of administrative tasks), would provide a distorted and superficial image. Carol Bohmer, also in this book, concurs that comparison between historical and contemporary displaced scholars shows that current refugee scholars are subject to "a perfect storm of difficult conditions as both academics and immigrants". This unique situation encompasses both academic and visa precarity and cannot be easily compared with historical examples. Instead, this book attempts to bring historical and contemporary figures into conversation with one another. On the one hand, contemporary scholars can often answer the questions one would want to ask from historical figures but are not able to. On the other hand, the impact of displacement on the production of academic knowledge by contemporary scholars could most likely only be seen from the perspective of time, as in the case of some historical figures discussed in this volume. There are, however, similarities in the biographies in academic narratives that include personal and academic narratives connected to the condition of exile and the experience of asylum and refuge policies and procedures; human rights, justice and the need to act; development of one's academic career and scholarly identity; and, finally, the relationship to one's home country, including contesting home regimes, which is a focus of the chapter in this book by Svensson. As he writes, displaced academics are often instrumental in contesting authoritarianism from a point of experienced necessary social change in order to identify and potentially delegitimize the home-state hierarchical systems.

\section{Displacement and contemporary neoliberal academia}

Academics for Peace themselves have arguably been most vocal about the current precarious conditions of displacement and this has reflected their situation and has had an impact on their work. As Seçkin Sertdemir Özdemir, Nil Mutluer, and Esra Özyurek wrote:

while working together to decode the legal system in Turkey, navigate immigration law in various European countries, and convince 
universities to accept Turkish scholars at risk as visiting scholars, we found ourselves, like other scholars in exile before us, self-reflexively theorizing the exilic conditions of knowledge production and academic employment that now affect our own colleagues' lives. ${ }^{30}$

In particular, they notice how neoliberal pressure on the universities since 1980 has changed the situation of displaced scholars nowadays in comparison to, for instance, the 1930s and 1940s. As their SAR scholarships end, they claim that they become temporary qualified additions to the academic labour reserve in the commodified education system. ${ }^{31}$ However, the primary focus of exile scholarship has been on the success stories. Even though financial hardships and social and intellectual isolation have been discussed extensively, little is known of those scholars who did not manage to find positions at foreign universities and whose knowledge has been effectively silenced by their exile. Usually those scholars who found academic positions were either recognized and well-connected already before they left or were young enough to re-educate themselves at the host states' universities. Judith Friedlander in her recent book on the University in Exile, established at the New School for Social Research in 1934, calls the selection-making process brutal. ${ }^{32}$ Even though the competitiveness based on scientific merit applies to all scholars, displaced and non-displaced alike, such practices resembled a very tough recruitment process rather than assistance to scholars in distress. Extremely high requirements were imposed on scholars-refugees from Nazi Germany and this is visible in the scholar classification by Rockefeller Foundation's director, Alan Gregg:

Categories of scholars to be aided: Distinguished scholars of established reputation (Class I), and brilliant younger scholars of proved ability (Class II), the young men of promise (Class III), on the other hand, should be excluded. ${ }^{33}$

As Kaius Tuori shows in this volume, beyond a small number of well-known scholars who developed their careers in exile, the vast majority never achieved such success. For many, exile was a process of marginalization and silencing due often to both structural or personal factors, and their academic careers were either put on hold or abandoned completely. However, the ethos of the exiled intellectual has often been glorified and only success stories attracted attention. This is even more important to consider in the case of contemporary scholars in neoliberalized academia who point out that scholarships are usually granted to those educated in North American and European universities and publishing in high-ranking journals in the dominant academic languages of English, French and German. In their words, academic competitiveness becomes the most important basis for protection from persecution. ${ }^{34}$ As Asl1 Vatansever, a displaced academic from Turkey herself, writes, academic knowledge in this context can be viewed "as both capital and commodity in today's capitalism", ${ }^{35}$ contributing to the precarity of scholars and researchers. In her study on de-subjectivation and re-subjectivation of Academics 
for Peace she shows that "the precariousness caused by the short duration of risk-scholarships is perceived by the signatories as a trouble primarily related to being in exile". As Vatansever claims, however, in fact this precarity is conditioned by the structure of the academic labour markets. ${ }^{36}$ Therefore the solution to such a situation - stepping out of being 'exiles' and becoming 'academics' - is unable to channel re-subjectivation as, when their exile scholarships end, they join the surplus academic labour force. ${ }^{37}$

This condition of the academic precarity of displaced scholars is fuelled by globalized academia, which encourages internationalization and mobility. Universities obsessively count publications and visiting scholarships, and mobility is seen as the way to market or brand the university itself. ${ }^{38}$ According to Gurminder Bhambra, the current marketization of the university actually attacks the diversity of knowledges, resistance, and meaningful social critique within academia. ${ }^{39}$ In addition, the political economy of academic work pushes knowledge production outside of the academia through outsourcing and subcontracting, ${ }^{40}$ including the intellectual work of refugee and migrant scholars. As Nadine Hassouneh and Elisa Pascucci show in their chapter in this volume, mainstream humanitarian organizations employing or contracting refugees to conduct humanitarian work and research in the field, manage knowledge and knowledge production in ways that uphold, rather than question, global racialized inequalities. As they show, forms of knowledge brought to refugee and humanitarian regimes by people with a refugee background tasked with providing protection and assistance to refugees, is often not credited or recognized through remuneration. Hassouneh and Pascucci's chapter also shows that studying the impact of exile and displacement on knowledge production cannot be limited to the knowledge produced by scholars and intellectuals. Thanks to, for instance, existing letter correspondence and memoirs of historical figures, as well as the current development of digital technology, the knowledge produced by all refugees and displaced persons has been and will be accessed and shared. Pedro Magalhães and Laura Sumari in this volume also show the important role of migrant communities for the production of knowledge. By quoting the study of Tekalign Ayalew Mengiste, they highlight how knowledge is produced by migrants, their families and friends at home and in diaspora, as well as co-travellers along the migration routes. ${ }^{41}$ Therefore, despite its primary focus on scientific knowledge production, the aim of this volume is also to consider knowledge production in exile by decentring the figure of the intellectual - historically white, male and western - to highlight the figure of the exiled, displaced and migrant knowledge worker, who is not necessarily based at academic institutions.

The aim of this volume is therefore to present an alternative narrative of exile and 'refugee knowledge' or displaced knowledge that is generative, yet that does not tap into the neoliberal productivity discourse. Focusing on the multifaceted forms of knowledge emerging in the context of migration and mobility not only allows one to understand movement and mobility, as well as those who are on the move, as a socially constitutive power but also to go beyond methodological nationalism and Eurocentrism. ${ }^{42}$ The editors and 
authors are, however, aware of difficulties linked with avoiding methodological nationalism, as Magalhães and Sumari underline in this volume. Indeed, de-naturalizing nation-states in migration research requires careful consideration of the situatedness of academic knowledge production. In particular, it underlines the responsibility of the researcher to become more aware of their beliefs and positionalities. Doing research requires constant and continuous self-reflexivity regarding multiple positionalities and power (a)symmetries, questioning the naturalized role of the nation-state in social sciences and especially migration and refugee studies.

Like methodological nationalism, the attempt in this volume has been to tackle the problem of Eurocentrism in research - where dominant producers of global knowledges coming from Europe and the Anglophone West can "write with authority about anywhere", but those from outside these regions are only allowed to write about "particular places and when doing so must use the frameworks of the global knowledge producers" ${ }^{43}$ This is what Keguro Macharia calls 'being area-studied'44 and Vatansever "thematic apartheid". ${ }^{45}$ For instance, Prem Kumar Rajaram shows in his chapter in this volume how Eurocentrism is visible in both historical and contemporary accounts. His research on narratives of migrant tea workers in colonial India and the problems that displaced people face in accessing higher education in Europe nowadays exposes the approach to knowledges by colonial subjects and refugees. As Rajaram writes, subaltern others enter into formal and public relations as lesser subjects, having to adapt to dominant norms while having their own narratives and ways of knowing diminished in value. This derogation of value enables the dominant positions of key concepts that fuel methodological nationalism and Eurocentrism like the nation-state or what Rajaram defines as state-nation-community. In the same manner the Peace Academics displaced in Europe highlight how they "are persistently expected to give talks, interviews, and lectures and do research on Turkey exclusively - regardless of their actual disciplines and research interests". ${ }^{46}$ Similarly, one of the interviewees in Kmak and Farzamfar's study shows how displaced scholars are often considered to be experts only on their own region, such as an expert on whatever happens in Africa, as if it would be a unified continent.

This approach is also visible in the tendency to classify and contain the community of refugees and displaced persons into one particular unit that also orients the dominant form of thinking about them. It is, for instance, visible in the ways that the European Union defines its identity against the refugee or a migrant, rather than accepting that it is itself shaped by refugees' knowledge about it. The EU pretends to have knowledge of the refugee rather than being known by the refugee. As Bergholm and Toivanen demonstrate in this volume, these dominant narratives contribute to categorizing refugees and migrants in stereotypical and harmful ways that hinder recognition of the refugees' own knowledge and hearing their voices. Refugees are seen as a source of the 'crisis', as a dangerous unknown, as a group that needs to be helped, or as saviours of Europe, able, for instance, to balance the demographic dependency ratio. 
This volume is an attempt to go beyond these hegemonic perspectives and in doing so to recognize the multiplicity of ways to know, think or write about the knowledges that are not only being affected by Europe or European citizens, but are also affecting how Europe or European citizens see themselves. This volume underlines that scholarly self-reflection on the nature of their own subjectivity and the context in which they create scientific knowledge is rooted in many locations and homes. This approach proves particularly fruitful for the endeavour undertaken by this book as it challenges the national order of things and institutionally structured ways of knowing.

This approach also confirms that the dichotomy of belonging and not belonging rooted in rigid categories of citizenship and nationality is misleading and that displaced persons may belong simultaneously to more than one place. ${ }^{47}$ For instance, even though John Herz, a lawyer and scholar of international relations, called himself a traveller between two worlds, and, according to his biographer Jana Puglierin, never felt completely happy with this inbetweenness, ${ }^{48}$ he seemed to accept his cosmopolitan position. In the interview with Puglierin in 2005 (just before he died in December that year), he said:

I now actually feel less like a traveller between two worlds than a traveller between all worlds. That is, I see myself less as a European or American and more as a resident of this planet, a planet that is becoming too small. I feel cosmopolitan more than limited to a particular cultural field or part of the earth.

Similarly, sociologist Reinhard Bendix, who thought of himself as a cultural hybrid and as never fully belonging to one community, underlined that:

In the modern world of Western civilization, all of us confront the triple issue of the individual, the nation, and the intermediate groups, a division which is ultimately incompatible with individualism, and the nationstate. But only ultimately. In the proximate world in which we live, all three exist in uneasy combination. ${ }^{49}$

\section{Nomadic knowledges}

How therefore does one reconcile the precarity of displacement with this mobile, or, in the words of Herz, cosmopolitan subjectivity? As Asl Vatansever shows in her book, such reconciliation would require a shift in focus in an affirmative fashion from exile towards the nomadic mode of existence as a source of subjectivity. ${ }^{50}$ She writes:

[t]hus, as it turns out, one of the main obstacles facing a re-subjectivation is not the exilic or nomadic situation per se, but the romanticization and absolutization of exile in a way as to exclude a certain group of people as an "extraordinary case" from the regular discourse on labour relations within the academic sector. ${ }^{51}$ 
This would mean adopting a nomadic identity and accepting the permanent, self-imposed exile as an academic way of life - a practice adopted by such contemporary thinkers as Edward Said, Michel Foucault or Rosi Braidotti. ${ }^{52}$ Similarly, Svensson in this volume shows how a primary identity of his interlocutors is the global nomad, as they choose the uncertainty of global settings with like-minded individuals in preference to home regimes. Despite the upsurge of authoritarian governments across the world, alternative prospects such as the choice to become nomadic may also be increasing to enable individuals such as Svensson's interlocutors to criticize and transcend repressive mechanisms.

Would such an attempt at re-subjectivation, however, still lead to exceptionality attached to academics who can turn their lack of fit into the world into their academic identity? For Vatansever, such a perspective could rather lead to new collective and innovative modes of resistance against the structural conditions of precarity. ${ }^{53}$ She refers to the concept of nomadic identities, developed by Rosi Braidotti, as allowing one to leave the "purgatory" of being kept in reserve as a surplus academic labour force towards "active production of multiple forms of belonging" and allegiances. ${ }^{54}$ How, however, does one become nomadic in the contemporary academia? In conversation with Aslı Vatansever facilitated by SAR Italy in October 2020, Magdalena Kmak discussed the particular difficulty of such a position that challenges the habitual way of thinking rooted in academic tradition and academic identity and forces new ways of doing research. This position can be illustrated by an account by a doctoral student interviewed by Vatansever:

What I am trying to do now is to mobilize my intellect and the intellectual activities that I value, so that I can continue to pursue those activities anywhere in the world. And this sank in: I am trying not to make any life plans depending on a place, an institution, or a country anymore. I internalized the knowledge that anything can happen anytime. Thus, I am trying to come up with ideas for intellectual activities that I can continue to do wherever I should go in the world..$^{55}$

In addition to the difficulty of de- and re-subjectivation as a nomadic scholar that this quote illustrates, the danger is that nomadic identity, despite being difficult to imagine and understand, may become romanticized in contemporary scholarship, leading to its superficial application as a solution to the precarious conditions of contemporary migrants, refugees and academics. One response to this might be to focus on precarity as a general condition "experienced by different segments of the reserve army of labor". ${ }^{56} \mathrm{Or}$, as Ali Ali writes in this volume, such an approach could lead to understanding that precarity does not only concern scholars at risk in contemporary academia or academics as such but that it is a general feature in the contemporary world that can become a source of emancipation. An experience and embodiment of precariousness can contribute to the creation of yet another form of knowledge - a noteworthy and grievable knowledge, emphasizing the need 
for and importance of individual and collective grieving and grievability for the production of knowledge on how to live and survive socially.

\section{Content of the book}

Scholarly knowledge is the primary focus of the volume, but the meaning, production and scope of "refugee scholarship", generated at institutions of higher education, is critically discussed. At the same time, this volume focuses on the "refugee knowledge" produced outside of these institutions and scrutinizes conditions of their validation or silencing. The contributors are scholars from various disciplines, with both a personal and a scholarly interest in refugee knowledge and refugee scholarship.

This book falls into three thematic parts. The first part, "Beyond Methodological and Eurocentric Nationalism in Research on Scholarship", lays the methodological basis of the book in its first two chapters, Pedro Magalhães and Laura Sumari’s "Methodological Nationalism and Migration Studies: Historical and Contemporary Perspectives" and Prem Kumar Rajaram's "Refugee and Migrant Knowledge as Historical Narratives". Reflecting on how Europe and European citizens see themselves, Bea Bergholm and Reetta Toivanen analyse the reactions by different European institutions to the 2015 influx of asylum seekers in Europe in their chapter "Narratives on 'Refugee Knowledge' in the Institutions of Europe", while ElSayed Mahmoud ElSehamy explores Yassin al-Haj Saleh's concept of exile in the chapter "The World as an Exiling Political Structure. Yassin al-Haj Saleh's Conceptualization of Exile".

The second part, "Refugee Scholarship and Scholarly Identity", opens with a history of science perspective provided by Alfons Söllner's chapter "Exile and Emigration from the Third Reich - Stages and Results of Research in Germany". The history of exile scholars in Europe - focusing on those fleeing from Nazi Germany in the 1930s and 1940s - and the relationship of academic exiles to modern scholars at risk is examined by Magdalena Kmak and Mehrnoosh Farzamfar in their chapter "Personal and Academic Narratives of Exiled and Displaced Scholars", while Carol Bohmer brings in an important historical perspective with a focus on the role of UNHCR and the 1951 Refugee Convention in her chapter "Refugee Scholars Then and Now". Christian Franklin Svensson uses an anthropological approach to networks aimed at helping refugees and vulnerable scholars - Scholars at Risk (SAR) and International Cities of Refuge Network (ICORN) - in his chapter "Beyond Authoritarianism: Migration, Uncertainty and a Sense of Belonging Among Public Intellectuals".

There is a tendency to celebrate the success stories of exiled scholars who either brought with them new ideas to their new home country, who reinvented themselves during or after exile, or whose scholarly ideas flourished after exile in their new home countries. However, for the vast majority of academic refugees, this was not the case. This is explored in the third part of the volume, "Silencing and Gatekeeping Knowledges". In his chapter "The 
Silenced Majority: Academic Refugees and the Vicissitudes of Readaptation", Kaius Tuori outlines some of the major dangers and negative factors facing refugee scholars. Issues of silencing and marginalization are tackled in more detail in Ali Ali's chapter, "Reframing the Subject - Affective Knowledge in the Urgency of Refuge", which threads together the issues of precarity, subjectivity and grievable knowledges. The book closes with a strongly contemporary chapter, drawing on interviews with Syrian aid workers, by Nadine Hassouneh and Elisa Pascucci, "Nursing Trauma, Harvesting Data: Refugee Knowledge and Refugee Labour in the International Humanitarian Regime".

Even though the chapters do not aim to provide a comprehensive approach to take on the topic of "refugee scholarship" or "refugee knowledges", the book serves as a starting point for further discussion not only about the historical and contemporary role of refugee and exiled scholars but also about the conditions of contemporary European academia.

\section{Acknowledgments}

This work is part of the Academy of Finland-funded Centre of Excellence in Law, Identity and the European Narratives (funding decision numbers 312154, 336676, 312431, and 336678).

\section{Notes}

1 Kuhn, 1994.

2 Foucault, 2002.

3 Livholts and Tamboukou, 2015, 121.

4 Vatansever, 2020, 8.

5 Agamben, 2008.

6 Nail, 2015.

7 Vatansever, 2020, 8.

8 Mayblin and Turner, 2020, 8.

9 Mayblin and Turner, 2020, 33.

10 www.eurostorie.org/

11 Said, 2001, 180.

12 Burke, 2016, 208.

13 Burke, 2017.

14 Burke, 2017, 34.

15 Burke, 2017.

16 Krohn, 1993.

17 Ash and Söllner, 1996; Söllner, 1996; Fermi, 1968; Coser, 1984; Krohn, 1993; Rösch, 2014.

18 Jay, 1996; Söllner, 2006.

19 Tuori, 2019a; Tuori, 2019b; Tuori, 2020.

20 Scholars at Risk, 2020.

21 Camurri, 2014.

22 Tuori, 2020, 20; Burke, 2017; Kettler and Wheatland, 2019.

23 Tuori, 2020, 11.

24 Boccagni and Baldassar, 2015. 
25 See, for instance, Arnold Brecht, Letter to Anette Bushman, June 12, 1938. Arnold Brecht papers, The German and Jewish Intellectual Émigré Collections, SUNY Albany.

26 Tillich, 1961, 139.

27 Sukarieh, 2019.

28 Bodenheimer, 2016, 60.

29 Söllner, 1988, 58.

30 Özdemir, Mutluer, and Özyürek, 2019, 6.

31 Özdemir et al., 2019, 6.

32 Friedlander, 2019.

33 Edgcomb, 1993.

34 Özdemir et al., 2019, 17.

35 Vatansever, 2020, 29.

36 Vatansever, 2020, 119.

37 Vatansever, 2020, 136.

38 Ahmed, 2012, 52.

39 Bhambra, 2016, 965.

40 Sukarieh and Tannock, 2019.

41 Ayalew Mengiste, 2018.

42 These intellectual approaches in the broad social scientific research take the nation-state as a basis for societal organization, including the production of knowledge. See, for instance, van Baar, 2016; Braidotti, 2010; Sager, 2016, 43.

43 Mayblin and Turner, 2020, 35.

44 Macharia, 2016.

45 Vatansever, 2020, 56.

46 Vatansever, 2020, 57.

47 Sager, 2016, 48.

48 Puglierin, 2008, 423.

49 Puglierin, 2008, 424.

50 Vatansever, 2020, 136.

51 Vatansever, 2020, 146.

52 Vatansever, 2020, 148.

53 Vatansever, 2020, 80.

54 Vatansever, 2020, 81.

55 Vatansever, 2020, 111.

56 Vatansever, 2020, 8.

\section{Bibliography}

Agamben, Giorgio. 2008. "Beyond Human Rights." Social Engineering 15: 90-95.

Ahmed, Sara. 2012. On Being Included: Racism and Diversity in Institutional Life. London: Duke University Press.

Ash, Mitchell G., and Alfons Söllner, eds. 1996. Forced Migration and Scientific Change: Émigré German-Speaking Scientists and Scholars after 1933. Cambridge: Cambridge University Press.

Ayalew Mengiste, Tekalign. 2018. "Refugee Protections from Below: Smuggling in the Eritrea-Ethiopia Context." The ANNALS of the American Academy of Political and Social Science 676, no. 1 (March): 57-76. doi:10.1177/0002716217743944.

van Baar, Huub. 2016. "Evictability and the Biopolitical Bordering of Europe." Antipode 49, no. 1: 212-230. 
Bhambra, Gurminder K. 2016. "Postcolonial Reflections on Sociology." Sociology 50, no. 5: 960-966.

Boccagni, Paolo, and Loretta Baldassar. 2015. "Emotions on the Move: Mapping the Emergent Field of Emotion and Migration." Emotion, Space and Society 16 (August): 73-80. doi:10.1016/j.emospa.2015.06.009.

Bodenheimer, Rosemary. 2016. Edgar and Brigitte: A German Jewish Passager to America. Tuscaloosa: University of Alabama Press.

Braidotti, Rosi. 2010. "Nomadism: Against Methodological Nationalism." Policy Futures in Education 8, no. 3: 408-418.

Burke, Peter. 2016. "Silver Lining: On Some Intellectual Benefits of Exile.” Storia Della Storiografia 69, no. 1: 39-48.

Burke, Peter. 2017. Exiles and Expatriates in the History of Knowledge, 1500-2000. The Menahem Stern Jerusalem Lectures. Waltham, MA: Brandeis University Press/ Historical Society of Israel.

Camurri, Renato. 2014. "The Exile Experience Reconsidered: A Comparative Perspective in European Cultural Migration during the Interwar Period." Transatlantica. Revue d'études Américaines. American Studies Journal 1. doi:10.4000/ transatlantica.6920.

Coser, Lewis A. 1984. Refugee Scholars in America: Their Impact and Their Experiences. New Haven and London: Yale University Press.

Edgcomb, Gabrielle Simon. 1993. From Swastika to Jim Crow: Refugee Scholars at Black Colleges. Malabar, FL: Krieger Publishing Company.

Fermi, Laura. 1968. Illustrious Immigrants: The Intellectual Migration From Europe 1930-1941. Chicago and London: The University of Chicago Press.

Foucault, Michel. 2002. Archaeology of Knowledge. London and New York: Routledge.

Friedlander, Judith. 2019. A Light in Dark Times The New School for Social Research and Its University in Exile. New York: Columbia University Press.

Jay, Martin. 1996. The Dialectical Imagination: A History of the Frankfurt School and the Institute of Social Research, 1923-50. 2nd ed. Berkeley and Los Angeles: University of California Press.

Kettler, David, and Thomas Wheatland. 2019. The Brute Facts of Political Life: An Intellectual Biography of Franz Neumann. New York: Anthem Press.

Krohn, Claus-Dieter. 1993. Intellectuals in Exile, Refugee Scholars and the New School for Social Research. Translated by Rita Kimber and Robert Kimber. Amherst: University of Massachusetts Press.

Kuhn, Thomas S. 1994. The Structure of Scientific Revolutions. 2nd ed. Chicago: Chicago University Press.

Livholts, Mona, and Maria Tamboukou. 2015. Discourse and Narrative Methods. London: SAGE Publications Ltd.

Macharia, Keguro. 2016. "On Being Area-Studied: A Litany of Complaint." GLQ: A Journal of Lesbian and Gay Studies 22, no. 2: 183-189. doi:10.1215/10642684-3428711.

Mayblin, Lucy, and Joe Turner. 2020. Migration Studies and Colonialism. Hoboken, NJ: John Wiley \& Sons.

Nail, Thomas. 2015. The Figure of the Migrant. Stanford: Stanford University Press.

Özdemir, Seçkin, Nil Mutluer, and Esra Özyürek. 2019. "Exile and Plurality in Neoliberal Times: Turkey's Academics for Peace.” Public Culture 31, no. 2: 235259. doi:10.1215/08992363-7286801.

Puglierin, Jana. 2008. "Towards Being a 'Traveller between All Worlds'.” International Relations 22, no. 4: 419-426. 
Rösch, Felix. 2014. Émigré Scholars and the Genesis of International Relations. Houndmills, Basinstoke: Palgrave Macmillan.

Sager, Alex. 2016. "Methodological Nationalism, Migration and Political Studies." Political Studies 64, no. 1: 42-59. doi:10.1111/1467-9248.12167.

Said, Edward W. 2001. Reflections on Exile and Other Essays. Cambridge, MA: Harvard University Press.

Scholars at Risk. 2020. Last visited May 13, 2021. https://www.scholarsatrisk.org/ event/free2think2020/.

Söllner, Alfons. 1988. "Otto Kirchheimer in Amerika. Emigrationserfahrung Und Internationalisierung Der Politikwissenschaft.” Zeitschrift Für Gesellschaftspolitik 27: $52-60$.

Söllner, Alfons. 1996. "From Public Law to Political Science? The Emigration of German Scholars after 1933 and Their Influence on the Transformation of a Discipline." In Forced Migration and Scientific Change: Émigré German-Speaking Scientists and Scholars after 1933, edited by Mitchell G. Ash, and Alfons Söllner, 246-272. Cambridge: Cambridge University Press.

Söllner, Alfons. 2006. "“Exilforschung” as Mirror of the Changing Political Culture in Post-War Germany." Journal of the Interdisciplinary Crossroads 3, no. 1: 63-74.

Sukarieh, Mayssoun. 2019. "Decolonizing Education, a View from Palestine: An Interview with Munir Fasheh." International Studies in Sociology of Education 28, no. 2 (April): 186-199. doi:10.1080/09620214.2019.1601584.

Sukarieh, Mayssoun, and Stuart Tannock. 2019. "Subcontracting Academia: Alienation, Exploitation and Disillusionment in the UK Overseas Syrian Refugee Research Industry.” Antipode 51, no. 2: 664-680.

Tillich, Paul. 1961. "The Conquest of Theological Provincialism." In The Cultural Migration: The European Scholar in America, edited by Franz L. Neumann, 138156. New York: A Perpetua Book.

Tuori, Kaius. 2019a. "Exiled Romanists between Traditions: Pringsheim, Schulz and Daube." In Roman Law and the Idea of Europe, edited by Kaius Tuori, and Heta Björklund, 35-52. London: Bloomsbury.

Tuori, Kaius. 2019b. "Introduction." In Roman Law and the Idea of Europe, edited by Kaius Tuori, and Heta Björklund, 1-14. London: Bloomsbury.

Tuori, Kaius. 2020. Empire of Law: Nazi Germany, Exile Scholars and the Battle for the Future of Europe. Cambridge: Cambridge University Press.

Vatansever, Asl1. 2020. At the Margins of Academia: Exile, Precariousness, and Subjectivity. Leiden: Brill. 
$\Rightarrow$ Taylor \& Francis

Taylor \& Francis Group

http://taylorandfrancis.com 


\section{Part I}

\section{Beyond Methodological and Eurocentric Nationalism in Research on Scholarship}


$\Rightarrow$ Taylor \& Francis

Taylor \& Francis Group

http://taylorandfrancis.com 


\title{
1 Methodological nationalism and migration studies
}

\section{Historical and contemporary perspectives}

\author{
Pedro T. Magalhães and Laura Sumari
}

\section{Introduction}

Social scientists struggle when they confront the phenomenon of nationalism. Their predicament is understandable, for, on closer inspection, nationalism is fraught with paradoxes. Their temptation to discard the topic altogether, and their refusal to engage with it on a deeper level even for critical purposes, might therefore appear justified. However, such a temptation must be resisted. In particular, migration studies and refugee scholarship have the duty to resist it, for their heuristic and critical potential hinges to a large extent on the capacity to question the national frameworks and nationalist assumptions, which, whether consciously or less so, still predominantly inform migration and refugee policies. This chapter approaches the issue of methodological nationalism in the social sciences from both a historical and a contemporary perspective. First, it delves into its early intellectual history by examining Eric Voegelin's reflections on 'national minds' in the interwar period. Thereafter, we examine the persistence of nation-state-centred concepts and methods in the context of migration and refugee studies, and we discuss different conceptual tools for overcoming the insufficiencies of methodological nationalism, weighing both their fruitfulness and their limits, while not ignoring the ineradicability of such frameworks.

Scholars of nationalism point out that, among other aporias, nationalist thinking combines a lack of substance and elaboration on the ideational level with unmatched effectiveness when it comes to mobilising people to take political action. Despite its 'philosophical poverty', ${ }^{1}$ nationalism seemingly has a grip on mass popular feeling like no other modern ideology. ${ }^{2}$ To be sure, it is debatable whether this combination is, in fact, paradoxical. Indeed, one does not need to endorse a dismal view of the masses and crowds to accept that theoretical sophistication might be a hindrance to the political 'power' of ideas. The importance of intellectual brokers who can mediate between 'grand thinkers' and street-level activists has long been stressed in the cases of the purportedly more elaborate ideologies of socialism and liberalism. ${ }^{3}$ The phenomenon of methodological nationalism, on the other hand, is much more puzzling, for it pertains to the impact of such a seemingly unsophisticated ideology on the ways in which scientists, and especially social scientists, have 
framed research problems, developed analytic tools and presented their findings and conclusions. This chapter sheds some light on this predicament.

Methodological nationalism is more elusive a phenomenon than ideological nationalism. It works mostly by way of unexamined assumptions and omissions. Still, it would be absurd to argue that the two are unrelated. In fact, it is the political success of nation and state-building processes in the modern age, fuelled by nationalist ideologies, which ultimately explains the persistence of methodological nationalism in the social sciences, for modern social science emerged and consolidated within the expanding national structures of higher education and scientific research. In an analysis of nationalism as a political ideology, Michael Freeden notes that the nationalist universe of meaning revolves chiefly around the core principle that the nation constitutes the irreplaceable framework for identity and culture. This principle generates an object of reverence that ranks above all other individual or collective subjectivities and nurtures the nationalist desire, framed as an inalienable right, to consolidate the supposedly primordial cultural unit of the nation as a sovereign political unit. Territorial contiguity and historical continuity, real or imagined, as well as an emphasis on affect and emotion that has no parallel in other modern ideologies, are the resources nationalists draw upon to foster sentiments of belonging and solidarity. ${ }^{4}$

Nationalism has crept into the social sciences not in its overt ideological forms - or, at any rate, not only in such forms - but rather by their taking for granted, as given and natural, the nationalist image of the world. Just as it trickles down to ordinary language and everyday practice until it becomes virtually unrecognisable as such, ${ }^{5}$ nationalism exerts a powerful influence on the human and social sciences by furtively suggesting that the lines separating nation-states from each other on political maps coincide with those that single out the meaningful units for social scientific inquiry. Wimmer and Glick Schiller ${ }^{6}$ identify three analytically distinct, but in practice overlapping, modes of methodological nationalism: ignorance, naturalisation and territorial limitation. Ignoring the national framework of modernity is a characteristic feature of social theory, with its grand narratives of epoch-making transitions from traditional, pre-modern communities to modern society. If the changes brought about by capitalism - a global and transnational phenomenon if there ever was one - constitute the focal point of modern social theory, nationalism is arguably its blind spot. In other words, social theory has failed to problematise the perplexing fact that the transition to an allegedly homogeneous type of capitalist/industrial society has proceeded hand in hand with the creation and strengthening of discrete national political communities. This lack of theoretical engagement leads, at the level of empirical research, to the naturalisation of the principle that the nation, or society understood as strictly contained within nation-state boundaries, constitutes the most suitable framework for social scientific analysis. Such naturalisation, ultimately, limits the territorial imaginary of the social sciences and removes from sight, with the help of statistical data collected by - and for the specific purposes of - nation-states, the porosity of national borders. 
The bias that accrues from such silent background assumptions is as difficult to expose as it is to avoid. Although efforts at dodging and debunking methodological nationalism are in general commendable - especially in the study of such topics as migration, which has been particularly affected by it - it would be a naïve presumption to expect that they could help us attain an 'objective' understanding of social reality. What stands to be gained from overcoming the alluring self-evidence of a world divided into discrete nationstate containers is not the world as it really is, but merely another, possibly novel yet also irremediably incomplete, perspective on it. Above all, the challenge of methodological nationalism should make us aware of how inescapably the theoretical language we, as scholars, use to make sense of the world is shaped by the intellectual, social and political forces around us, thus precluding the possibility of a clear-cut distinction between scholarship and politics, science and ideology.

Thus, in this chapter we focus on the plurality of approaches that follow from problematising the silent assumptions of methodological nationalism. Refusing to ignore the national framework of modernity and/or to naturalise the nation-state as a unit of analysis is always only a first step, one which can lead in different directions depending on the intellectual and political forces that drive it. Awareness of the analytical limitations imposed by nationalist frameworks can translate into several emphases: an emphasis on the processes and fluxes that cut across nation-state borders and therefore call for a macroscopic approach; an emphasis on the rediscovery of the internal diversity that nation and state-building processes sought to erase through various policies of homogenisation; or an emphasis on the persistent ideological and political strength of nationalism. In the final analysis, each encounter with the problems of methodological nationalism generates a story of its own, which is intertwined with the histories both of nationalism proper, as a movement and as an ideology, and of the social scientific discourses informing it. To illustrate this point, we begin with a contribution to the intellectual history of methodological nationalism.

\section{Struggling with methodological nationalism avant la lettre: Eric Voegelin and the 'national types of mind' (1920-1930)}

From an historical perspective, the concept of methodological nationalism is a recent artefact. The term was coined by the sociologist Hermínio Martins in the 1970s, but it played only a peripheral role in his dense plea for a historically and philosophically reflexive sociology. The coinage of the expression seems to be almost accidental, as the concept does not in fact occupy a prominent place in Martins's reflections. However, its emergence can be read as signalling an awakening to the entrenchment of nationalist assumptions in social-scientific methodology after the Second World War. In the brief passage where he comes up with the term to refer to the shortcomings of contemporary macro-sociological studies, Martins ${ }^{7}$ points out that scholars succumb unreflectively, and irrespective of nationalist political leanings, to 
'national pre-definitions of social realities'. What is more, he notes that migration studies in particular reveal the inadequacy of such 'pre-definitions', with their focus on immigration and integration in the host society resulting not from valid scientific reasons, but rather from the institutional embeddedness of the social sciences in rich, immigrant-receiving societies. ${ }^{8}$

Roughly one decade later, in an article that took stock of classical social theory's neglect of nationalism, Anthony D. Smith related the pervasiveness of methodological nationalism to 'the difficulty for a discipline so impregnated with the selfsame assumptions as those held by its object of study, to stand back and realize its historical peculiarity'. ${ }^{9}$ But Smith, much like the other renowned scholars who accompanied him in a new wave of nationalism studies that peaked in the $1980 \mathrm{~s},{ }^{10}$ was only marginally interested in methodological issues. The research problems pertaining to the origins, diffusion and consequences of the phenomenon had too strong a grip on these scholars of nationalism to allow for anything more than a secondary concern with the unexamined adoption of national(ist) analytic frameworks by the mainstream social sciences. ${ }^{11}$ Ultimately, only when the limitations of such frameworks became more glaring as a result of growing global interdependencies did a systematic critical treatment of methodological nationalism, as well as an epistemic move away from it, become possible - and it comes as no surprise that this was achieved, first and foremost, by migration scholars. ${ }^{12}$

However, it would be overly simplistic to reduce the story of metatheoretical reflections on the methodological implications of nationalism to a linear account departing from a position of ignorance and short-sightedness, during the heydays of classical social theory and nation-state-building processes, and culminating in a systematic critique motivated by the rise of a new, post-national constellation. In this section, we sketch the early trajectory of a scholar who began his academic career in interwar Vienna, struggling with methodological nationalism before the term had been invented. Although his struggle was not successful in the sense of leading to a systematic comprehension of the phenomenon, it is worth recovering here for two main reasons. On the one hand, Eric Voegelin's case provides some nuance to the charges of neglect and ignorance of nationalism levelled against classical social theory. On the other hand, it reveals some deep tensions and dilemmas crisscrossing scholarship and politics at the time, which arose from an early, though neither complete nor fully articulate, grasp of the repercussions of nationalism on social scientific research.

Voegelin completed a doctorate at the University of Vienna in 1922, with his thesis on the epistemological foundations of sociology in essence being a defence of Othmar Spann's idea of spiritual community (Gezweiung), in contrast to Georg Simmel's concept of interaction (Wechselwirkung), as the soundest methodological basis for sociological investigations. ${ }^{13}$ However, much more interesting than the theoretical arguments per se, are the sparse yet revealing references to the concrete problems that sociological research was supposed to address. For instance, when Voegelin specifies the claim that sociology should 'grasp the phenomenon [it studies] in its social nature', he adds that it 'must be able to tell us why a particular painting is a Dutch 
painting, why a particular philosophical system is French, etc..${ }^{14}$ By doing so, far from conflating the categories of society and nation, Voegelin is rather suggesting that national definitions of social entities, no matter how natural and intuitive they might appear, require further sociological elucidation. Instead of taking national labels for granted, sociologists must be able to explain why it makes sense to use them, why certain national labels capture the 'social nature' of a phenomenon better than other alternatives.

Voegelin is well aware of the fact that membership in a society need not be understood in national terms, but at the same time he is fascinated by the pervasiveness of the national colourings assigned to social and cultural objects, which occur even in the most improbable connections. In this regard, he mentions Pierre Duhem's study La théorie physique as a remarkable example of how to employ the sociological method as he understood it. To be sure, this is a bit of an overstatement, since Duhem was only somewhat interested in the 'social nature' of theoretical physics. However, the contrast that Duhem drew between the abstract penchants of French (and German) physicists, on the one hand, and the tendency of their English counterparts to construct sensorially graspable models on the other hand, impressed Voegelin deeply. ${ }^{15}$ Even at such a point where the human mind strives for the highest degrees of abstraction and objectivity in the elucidation of natural phenomena, it apparently does so through different, socially/nationally determined routes.

If not even theoretical physics could efface the traces of national provenance, then the social sciences were bound to reveal them much more starkly. But how starkly would they reveal such traces, and how would it affect their claims to scientific validity? Voegelin wrestled with this question in his 1922 essay on 'The Social Determination of Sociological Knowledge'. In it, he evaluates contemporary British sociology, and precisely by discerning just what makes it British, Voegelin hopes to define the concept of a nation in the hope of better ascertaining its epistemological implications. Since 'a national element is a necessary concomitant in the determination of knowledge', no science, hard or soft, could aspire to produce only judgments scrupulously valid to 'consciousness generally', in a Kantian-transcendental sense. However, he proceeds, this must not lead one to abandon 'the possibility of an objective science as well as of an objective critique'. After all, Duhem ${ }^{16}$ had shown that the two nationally distinct modes of theorising could still contribute to the consolidation of a unified theory of physics. Voegelin's suggestion, thus, is that one should conceive of the 'system of knowledge' as a two-fold structure. On one plane, which he deems 'objective', scientific progress unfolds in the form of judgements that meet the requirements of validity for 'consciousness generally'. These judgements, however, emerge from another, 'subjective' plane that is inescapably marked by its social/national provenance. ${ }^{17}$

The problem with this dualistic construct is, however, that its own conception of the locus of 'true' scientific progress stems from a particular national perspective, one which is therefore presumed to have privileged access to the transcendental realm of objectivity. This leads Voegelin to the following, weirdly nationalist conclusion: 
In order to produce useful findings relevant to the type of transcendental sociology we have outlined here, sociologists, in terms of their mental structure, would have to be transcendental philosophers - and whether we can find this type of philosopher outside of Germany seems highly questionable. $^{18}$

During the 1920s, two factors would help Voegelin see past this strict neoKantian framework: lengthy research visits to the United States and France and his immersion in Max Weber's sociological work. Although both are relevant for a complete account of the development of his conception of 'national types of mind', we will focus here only on the latter. Weber is arguably the member of the classical sociological canon who can least be charged with being blind to the role of nationalism in the making of the modern world. To be sure, his actual contributions to the topic are brief and fragmentary, but the reason for this is hardly the kinds of unexamined omissions and ignorance that present-day critics of methodological nationalism detect in mainstream social theory. ${ }^{19}$ The rather more prosaic explanation is that Weber did not live to complete his political sociology, where he intended to give an account of the rise of the modern nation-state. Still, the six-page fragment published posthumously in Economy and Society contains important clues that later students of nationalism - often without any discernible Weberian influence - would pursue.

Weber's analytic move sought to disentangle the compound 'nation-state' and reflect on the nature of each of its components. While 'the state' is, above all, a rational construct, one graspable via a precise definition ${ }^{20}$ and amenable to the ideal of value-free inquiry that modern social science aspires to, "the nation' resists clear-cut definition and confronts scholars head-on with an irrational sphere of ultimate values and commitments. Furthermore, the difficulties are sharpened by the fact that scholars belong precisely to the social group that is most attached, by way of both material and ideal interests, to the valueladen complex of 'the nation'. Indeed, whereas the idea of 'the state' is carried forward by the political elites, the 'national' ideal is advocated primarily by the intellectual strata of modern societies. Paradoxically, those very same scholars who, because of their scientific vocation, should study 'the nation' as objectively as possible, i.e. from an axiologically neutral perspective, are at one and the same time those who, due to their social position among the intelligentsia, 'are specifically predestined to propagate the "national" idea'. ${ }^{21}$ Being a German nationalist himself, Weber was well aware of the weight of such a paradox.

Voegelin, too, proceeded to elaborate on the social/national determination of social scientific minds in the spirit of the scholar he viewed as the 'mightiest symbol' of his time. ${ }^{22}$ In December 1930, he delivered a lecture-series entitled 'National types of mind, and the limits to interstate relations' at the recently established Institut Universitaire de Hautes Études Internationales, in Geneva. Unsurprisingly, the lectures generated no enthusiasm in the capital city of interwar internationalism. The directors of the Institut, who had considered offering Voegelin a position based on an endorsement by his mentor 
Hans Kelsen, eventually decided against it. Indeed, sentences such as the following were hardly a good calling card in the same city that hosted the League of Nations:

A sociologist who has even only a superficial knowledge of the sociological literature outside his own nation may find his attention attracted to the interesting circumstance that another nation's results in sociological theory are of negligible value for his own work when he takes them as objective science. There is no Internationale of social theory as there is of mathematical or physical theory. ${ }^{23}$

Considering the evolution of Voegelin's intellectual trajectory, the above summation signals a clear break with the neo-Kantian influence exerted by Kelsen. In other words, while neo-Kantian epistemology might be adequate for our understanding of the natural sciences in general and Newtonian physics in particular, it is irrelevant for the social sciences - and for all the social sciences at that - because meaningful social phenomena cannot be subsumed under a unified theory of experience. But if social phenomena must be grasped, so to speak, from within, by someone who is implicated in such phenomena, then the tense situation that Weber noted concerning the study of 'the nation' is indeed unavoidable. Voegelin's answer differs, however, from that of Weber. For Weber, the crux of the matter was choosing which 'God' to serve, which fundamental calling to pursue: science or politics? For Voegelin, the paradox, being more than a matter of choosing between two supposedly incompatible alternatives, called for rigorous self-reflection. Torn between irreconcilable demands, the scholar must 'be the perfect master of his thought and ... know in all clarity what parts of his thought may be regarded as rational, and where the irrational belief comes in'. ${ }^{24}$ To be the servant of rational science, and rational science only, was not an option, because according to his 'existential conception ... there is not a realm of politics an sich, and beyond it the sphere of science, but political science itself is a part of political existence'. ${ }^{25}$ The mark of a scholar's intellectual integrity, and of his/her political responsibility, was the ability to distinguish thoughtfully between the elements of rational-scientific truth and those of irrational national belief that necessarily inform one's work. Conflating the latter with the former, taking belief for unbiased truth, was the first step in the sacralisation of one's own national beliefs and the incomprehension of other nations' beliefs. The scholars who are able to maintain such a distinction are not quite the type of socially unattached intellectual in whom Karl Mannheim ${ }^{26}$ had placed his hopes of social reconstruction in an important contemporary work, precisely because their national attachments are ineffaceable, but they might still contribute to further the understanding between nations by 'having a clear picture of each other's peculiar beliefs' ${ }^{27}$

Whether Voegelin was able to live up to this demanding image of the nationally self-reflecting scholar in the years leading up to the Anschluss of Austria by the Nazis is somewhat doubtful given his legitimation of the 
nation and state-building policies of Austrofascism. ${ }^{28}$ Still, his struggle during the 1920s with the problem of 'national minds' and their influence on knowledge production can be interpreted as an early, tentative venture into the topical issues of methodological nationalism. Voegelin proceeded from epistemology to concerns that are more political. At first, still clinging to the possibility of achieving objective knowledge, he nevertheless recognised and tried to come to terms with the fact that every scientific theory is marked by its peculiar national provenance. Subsequently, in acknowledging the sheer force of nationalism as a political belief he was expressing the understanding that the social and political sciences cannot hope to remain insulated from it, but rather should aim to distinguish as clearly as possible between their rationally unjustifiable, nationalist commitments and their rational-scientific achievements. To be sure, Voegelin did not fully grasp what we today see as the problems of methodological nationalism, and much less did he arrive at a systematic critique of the phenomenon. Often enough, he took nationalist assumptions for granted - unsurprisingly, perhaps, for someone who was witnessing, with a sense of anxiety, the partition of the Habsburg Empire into discrete nation-states - but he certainly did not ignore the national framework of modernity and the perplexing questions generated by it. Later on, while in exile in the United States, he would treat nationalism as one of the ominous political religions of the modern age, an age he sweepingly condemned as one of spiritual corruption and 'theoretical retrogression'. ${ }^{29}$ However, such a critique of philosophical rather than social scientific interest falls beyond the scope of the present inquiry.

\section{Methodological nationalism in contemporary research on migration}

The national frame of modernity is particularly visible in migration management and in the development of migration and refugee studies shaped by the modern projects of nation-state building. ${ }^{30}$ Not only is the history of migration written largely from the viewpoint of nation-states, it is also most often written using concepts related to nation-states. ${ }^{31}$ Although the increased interest in migration and refugee studies related to the so-called 'refugee crisis' has given birth to productive debates on post-nationalism as well as denational and transnational citizenship that recognise the nation-state as merely one of the multiple layers of political membership, ${ }^{32}$ migrants are still often seen primarily as 'representatives' of their country of origin and/or of their nationality. This is visible in, for example, the sampling schemes of national surveys and statistics representing migration, which focus on the nationality of migrants as well as the crossing of borders, thus naturalising the roles of states. Equally, migration is often studied from the point of view of the recipient country since the recipient country is responsible for the asylum determination process as well as providing services to migrants. Immigration is, by definition, studied in relation to the nation-state receiving the migrant, who is entering the country from the 'outside'. ${ }^{33}$ This kind of research has focused strongly on integration, which has been seen as the 
'natural' terminal point to the migratory process. ${ }^{34}$ Just as nation-state institutions presumably provide the most relevant social context for understanding and studying migration, so too many researchers continue to assume that nation-states provide the most appropriate territorial framework for migration research. ${ }^{35}$

One reason that adhering to nation-state-related social and territorial frames in refugee and migration research may feel natural for researchers is that as determinants of juridical, social and cultural citizenship, nation-states are the bodies largely responsible for managing and organising migrationrelated issues. Migration processes and immigration law are heavily shaped by racialised conceptions of citizenship and national identity. Yet, it must be noted that national categories are not the sole markers of exclusion: racialised or ethnicised 'others', such as Blacks, Muslims or Roma, may well be citizens, but they become 'migrantised' by the nation-state. In addition to national borders, the boundaries of entitlement and disentitlement also relate to transnational capitalism - border regimes work especially to control the mobility of the poor. ${ }^{36}$ Various forms of exclusion are, thus, interlinked and inform each other.

The uncritical assumption of 'national' analytical frameworks leads to the perception that state borders are lines that naturally divide the world. ${ }^{37}$ Additionally, by equating nation with 'peoplehood' and 'society' through the notions of democracy, citizenship, social security and national self-determination, ${ }^{38}$ methodological nationalism enforces the division between 'us' and 'them' on various levels. The legal-administrative categories that label migrants are related to the nation-state through the dichotomy of national and foreigner. They easily simplify and overlook the complex realities shaping the lives of migrants and create essentialist understandings of migratory movements, as Bergholm and Toivanen point out in this volume. Reducing the realities of migrants to push-and-pull factors and studying them through a national or ethnic lens does not necessarily reveal much about the real-life situations of the people who, for various reasons, are crossing borders and choosing to remain in a country other than the one of their birth..$^{39}$ Thinking beyond methodological nationalism thus requires a disarticulation of the binary between 'insiders' and 'outsiders' and the acknowledgement of multiple positionalities. ${ }^{40}$ This is easier said than done, as we have seen above. Despite acknowledging the need for self-reflection on one's national positioning as a scholar, Voegelin himself remained throughout the interwar years largely trapped within a nationally determined framework of thinking. But what kinds of analytical tools can we use that are not coloured by the 'selfevidence of a world ordered into nation-states'? ${ }^{41}$

Although national thinking often determines discussions about migration, ${ }^{42}$ there are multiple ways of attempting to avoid the traps related to methodological nationalism in contemporary migration and refugee studies. The starting point for this endeavour is to realise how strong the hold of the nation-state has been as a unit of inquiry in the social sciences. To move beyond the container-like understanding of nation-states, scholars have started to pay more 
attention to transnational relations. This has led to an emphasis on diverse mobilities (e.g. cross-national, regional, permanent, seasonal) and the transnational nature of phenomena that are in various ways hybrid and cross-border, where the relations between local and global are intertwined through various connections in space and time. ${ }^{43}$ As a consequence of shifting the analytical gaze away from the nation-state framework, increased attention has been paid to, for example, examining various cross-border social entities, modes of communality and transnational connections within and between migrant communities. ${ }^{44}$ The various approaches that critically examine methodological nationalism are the focus of the following section.

\section{Pathways towards de-naturalising the nation-state}

Anna Amelina and Thomas Faist ${ }^{45}$ write about various possibilities of moving beyond methodological nationalism in empirical research on migration. They propose methodological transnationalism as a way to 'de-naturalize the concept of the national within migration studies' by rejecting the nation-state as the only point of departure for empirical analysis. ${ }^{46}$ The starting point for a transnational approach is to pay attention to the various practices of people and institutions that take place in and across multiple localities. This can be done by, for instance, identifying alternative social and territorial frameworks for situating empirical research: transnational social spaces, postcolonial contexts or the global cosmopolitan arena.

De-centring the nation-state can also be done by focusing on strategies of space formation and space appropriation that understand spaces not as fixed and static entities (containers), but as relationally defined process-like things, which constantly gain new meanings and are constructed through various connections and networks. ${ }^{47}$ For instance, studying hybridities, diasporas and cosmopolitanism provides alternative paths to challenging national exclusivity and particularisms, and to analysing the ways in which people relate to multiple localities and organise transnational activities through them. ${ }^{48}$ However, the notions of diaspora and hybridity still rely on national imagery and potential mobilisations around national symbols. ${ }^{49} \mathrm{In}$ terms of gathering research material, the complexity of transnational phenomena can be gauged by studying multiple geographic localities and/or social sites simultaneously. Amelina and Faist ${ }^{50}$ have proposed using multi-sited ethnography ${ }^{51}$ and mobile methods as non-national ways of contextualising research to overcome some of the shortcomings of methodological nationalism.

The critique of methodological nationalism allows us to free our research from unjustified national frames. ${ }^{52}$ However, there is a risk of overcompensating and portraying the transnational in an excessively positive light..$^{53}$ Detaching hybridities and diasporic formations from the parameters of unequal power relations can downplay the negative effects of globalisation..$^{54}$ Although proponents of cosmopolitanism have claimed that the significance of borders and nation-states has diminished through the processes related to globalisation, ${ }^{55}$ it is important to bear in mind the persistent global inequalities 
related to the freedom of movement. Cosmopolitanism has been criticised for, among other things, overlooking questions of class as well as ethnic origin. ${ }^{56}$ Globalisation and the power geometries related to it have reserved different roles for different groups of people when it comes to movement. ${ }^{57}$ For instance, globalisation has not meant the fading away of borders for tens of millions of people stuck in refugee camps or otherwise unable to move. Rather, it has led to the multiplication of borders. ${ }^{58}$ According to Jussi Laine, ${ }^{59}$

we continue to live in the world of borders, and ... the state's allure has not faded, in spite of the fact that many contemporary social processes are clearly beyond its scope. Territorial logic still leaves its mark on the way space is organised, and the nation-state continues to be the principal reality for the worlds' inhabitants, 'trapped by the lottery of their birth'.

For this reason, when researching migration the relevance of states and borders in relation to various mobilities should neither be forgotten nor regarded as natural. This is true especially in the context of the increased securitisation of migration and the consequential amplifying of national borders and boundaries. ${ }^{60}$ Bridget Anderson ${ }^{61}$ proposes employing what she calls methodological de-nationalism as an approach that recognises the relevance of borders and nations by investigating the impacts of state-imposed categories of both migrant and citizen on the lived experiences of people, while seeking to uncover the connections between diverse but interconnected exclusionary logics. Indeed, methodological nationalism becomes an issue when it starts to direct our research in a way that is blind to other meaningful frames of inquiry. National identities remain salient building blocks of belonging and identification for many people around the world, and like researchers, migrants and refugees also experience themselves and their environments and connections with others in a world order that, to a certain extent, must still be conceptualised as consisting of nation-states. Yet nationality is not the only, nor always the strongest, marker of identity. Identity and belonging are concepts that inform understandings of migration in the modern era. Identities are slippery concepts - dependent on context, meaning and time which involve 'individual and collective narratives of self and other, presentation and labelling, myths of origin and myths of destiny with associated strategies and identifications' ${ }^{62}$ Thus, national belongings only account for a certain part of identity construction, which is a dynamic, thoroughly complex process involving multiple, overlapping layers, connections and dimensions.

People hold memberships and feel belonging through different categorisations, depending on the context, situation and meaning, and markers of identity are always intersecting and crosscutting each other. Shifting the focus from national fixation towards multiple positionalities and interlinked markers of identity (such as gender, class, region, political orientation and stage in the life cycle) that affect the subjectivity of individuals is one way of reaching beyond methodological nationalism. However, critiques of this kind of intersectionality warn that fixing people into inter-related, yet permanent groups, namely 
class, gender and ethnicity, undermines the focus on social processes and practices. Floya Anthias ${ }^{63}$ moves beyond intersectionality, proposing the notion of 'translocations', which 'references the idea of "location" as a social space which is produced within contextual, spatial, temporal and hierarchical relations around the "intersections" of social divisions and identities of class, ethnicity and gender (amongst others)'. The term refuses to see migrants solely based on their places of origin and destination; it includes other 'locations' of identity and belonging, such as gender and class. Additionally, and according to Anthias, when viewed separately from intersectionality the notion of translocations moves away from crosscutting groups and categories, emphasising social spatio-temporal processes and the role of boundaries and hierarchies.

When seeking to construct new epistemological frameworks for migration studies, we must understand how knowledge is produced and where it is situated. The basic claim of social constructivism is that reality is socially negotiated - the nature of truth is rhetorical. Knowledge is produced and reproduced in social interactions between human beings and their social settings. ${ }^{64}$ Instead of aiming for 'unmarked' objectivity, Donna Haraway ${ }^{65}$ proposes an 'embodied objectivity', which takes into account the situated nature of all knowledge. In speaking out against various forms of 'unlocatable, and so irresponsible, knowledge claims', she argues for 'politics and epistemologies of location, positioning, and situating, where partiality and not universality is the condition of being heard to make rational knowledge claims' ${ }^{66}$ For Haraway, feminist objectivity means positioned rationality - situated knowledges that are about communities, not isolated individuals:

Situated knowledges require that the object of knowledge be pictured as an actor and agent, not as a screen or a ground or a resource, never finally as slave to the master that closes off the dialectic in his unique agency and his authorship of 'objective' knowledge. ${ }^{67}$

Migration is a complex process, one which requires and generates a great deal of knowledge. Especially in the context of clandestine migration, plans and decisions have to be made and risks managed in rapidly-changing conditions and through new encounters between people. ${ }^{68}$ Studying migration provides an important opportunity to examine processes of knowledge production precisely because migrants are people who have moved out of their 'usual environment' and have to deal with many forms of the 'unknown' to survive in their everyday lives while in transit and in new locations. The geographically dispersed and fluid transnational milieu of migrants offers a ground for new 'communities of knowledge' where collective practices and complex processes of generating and using knowledge in irregular mobility facilitate the migratory journeys. ${ }^{69}$ Tekalign Ayalew Mengiste characterises 'communities of knowledge' through

the diverse and dynamic strategies collectively devised and mobilized by migrants, their co-travelers, families and friends settled en route and in the diaspora, and friendly strangers and diverse facilitators to reduce 
risks in clandestine journeys and who allow for successful transits, while not discounting the violence and suffering encountered by migrants and refugees on their paths. ${ }^{70}$

Mengiste $^{71}$ highlights how the relationships, information sharing and previous experiences related to migratory journeys reproduce social relations and construct knowledge, which is vital for decision-making throughout the migration process. Investigating the possible situatedness of migrant knowledges through a framework other than that of the nation-state requires further attention and raises further questions. Together with reflecting on the situatedness of migrant knowledges, de-naturalising nation-states in migration research requires careful consideration of the situatedness of academic knowledge production. Voegelin ${ }^{72}$ already long ago touched upon the responsibility of the researcher to distinguish between the elements of rationality and those of belief related to his subjectivity as a member of a nation. Accounting for the "nationally selfreflecting scholar' is connected to the positionality of the researcher. By positionality, we mean the space at the intersection of social position as a set of effectivities (structure) and social positioning as a set of practices (agency). ${ }^{73} \mathrm{We}$ have already discussed the multiplicity of positionalities in relation to the migrants who are the focus of the research. But researchers, too, occupy multiple positionalities, which affect our understanding of the world and the way we conduct research. Privileging the role of national belongings and ignoring our intellectual bias in relation to nation-states easily leads to overlooking the meanings of other social divisions in understanding migrant experiences. ${ }^{74}$ To critically engage with the presuppositions of methodological nationalism and the reconfigured role of the state in migration research, developing a self-reflexivity with respect to a variety of meaningful social divisions and understanding the significance of these multiple positionalities are crucial.

Academic representations are produced in asymmetrical power relations between the researcher and the researched. Especially in migration research, various sensitivities are related to such relations and overlooking them easily results in producing colonialist discourses on and knowledge about singular, essentialised identities. ${ }^{75}$ Since the backgrounds and power positions of the researcher and the researched often differ from each other in various ways, there is a danger of reproducing divisions between 'us' and 'them'. Equally, considering the relationship between the researcher and the researched through solely national belonging and identity leads to methodological nationalism. Kyoko Shinozaki ${ }^{76}$ argues that through social positioning, and by realising the non-static nature of the boundaries between 'us' and 'them', we can restructure the researcher-researched power relationship. Along with reflecting on one's position in society in terms of gender, class and ethnicity, this entails questioning fixed binary oppositions, for example those between insider and outsider - or the powerful and the powerless.

In migration studies, boundaries are easily drawn following the lines that separate nation-states. Yet these lines are only one of the many social divisions shaping the lives of migrants as well as those of the people studying 
migration. Equally, they are constantly being drawn and re-drawn through the social interactions between the researcher and the researched. Tapping into the field of migration studies and doing fieldwork with migrants requires constant and continuous self-reflexivity regarding multiple positionalities when assessing fieldwork relationships and the power (a)symmetries related to them..$^{77}$ Creatively assessing the intersecting but fluid, multiple positionalities of the researcher, the researched and the relationships between them offers necessary tools for questioning the naturalised role of the nation-state in social sciences and especially migration and refugee studies.

\section{Concluding remarks}

Total avoidance of methodological nationalism is a difficult, perhaps even an impossible task. Not only for researchers trying to understand complex social phenomena, such as migration, but also for all individuals and groups involved in such phenomena, nation-states are among the categories through which we understand ourselves and our identities in relation to the world we live in. Nationalism seems to be gaining a stronger hold in politics in many parts of the world, and populist anti-immigration parties are gaining in popularity through their simplistic discourses on migration and refugees. The significance of state borders for most of the world's population is not diminishing. It is important for migration scholars to understand the consequences of both ignoring and naturalising the role of the nation-state as well as of territorially limiting our research to the nation-state. Although globalisation influences the power geometries related to nation-states and the movements of people between them, we continue to live in a world where such territorial logic largely informs our understandings.

This chapter began with a historical overview of the problem of methodological nationalism in the social sciences. In the second section, we delved into the intellectual 'pre-history' of the concept by examining Eric Voegelin's interwar reflections on 'national minds', which, despite having been articulated long before the term was coined, anticipate many of the questions and challenges that future critics of methodological nationalism have tried - and are still trying - to solve. Next, we introduced some of the challenges related to the dominance of nation-state-centred frameworks of analysis within the context of migration and refugee studies. Finally, we discussed some of the conceptual and methodological tools for acknowledging and overcoming the potential traps of methodological nationalism.

At the end of the day, there is no one answer for avoiding the pitfalls of methodological nationalism, neither are we sure that it is entirely possible. Although many migrants also contextualise their existence and connections with others partially through the frame of the nation-state, the possibility for 'communities of knowledge' not marked by this framing can emerge from the connections and relationships forged in the migratory process. The current dynamics related to transnational migration present us with a multiplicity of shifting landscapes of identity and belonging, which can be approached through methodologies that 
consider the multiple positionalities of both migrants and the people who study migration as well as the relationships between them.

\section{Acknowledgments}

We would like to thank the editors and contributors to this volume for their helpful suggestions and insightful comments on previous drafts of this chapter. Furthermore, the authors also gratefully acknowledge the financial support of the Academy of Finland funded Centre of Excellence in Law, Identity and the European Narratives, funding decision numbers 312430, 336677, 312431 , and 336678 .

\section{Notes}

1 Anderson, 1983/2016, 5.

2 Adams, 1993, 82.

3 See e.g. Hayek, 1949.

4 Freeden, 1998.

5 Billig, 1995.

6 Wimmer and Schiller, 2002, 302-308.

7 Martins, 1974, 276.

8 Martins, 1974, 276-277.

9 Smith, 1983, 26.

10 Gellner, 1983 and Anderson, 1983/2016.

11 For an overview of the research traditions - historical, sociological and anthropological - on nationalism, see Kramer, 1997 and Thompson and Fevre, 2001.

12 See Wimmer and Schiller, 2002.

13 Spann was Voegelin's supervisor, together with the positivist legal theorist Hans Kelsen - a rather unusual combination.

14 Voegelin, 1922a/2003, 22.

15 Duhem, 1906/2007, 114-15, 122-23; Voegelin, 1922a/2003, 22; 1922b/2003, 46; 1930/2003, 443.

16 Duhem, 1906/2007, 148f.

17 Voegelin, 1922b/2003, 29-30.

18 Voegelin, 1922b/2003, 48.

19 Although Talcott Parsons's structural-functionalist (mis)reading of Weber has certainly contributed to the situation that critics of methodological nationalism in social theory deplore.

20 Every undergraduate student of sociology or politics is bound to have come across this sentence at least once: 'a state is a human community that (successfully) claims the monopoly of the legitimate use of physical force within a given territory', in Weber, 1919/1946, 78, emphasis elided.

21 Weber, 1922/1968, 926.

22 Voegelin, 1925/2003, 117.

23 Voegelin, 1930/2003, 450.

24 Voegelin, 1930/2003, 463.

25 Voegelin, 1930/2003, 464.

26 Mannheim, 1929/1954.

27 Voegelin, 1930/2003, 475. 


\section{Pedro T. Magalhães and Laura Sumari}

28 Voegelin, 1934/2001, 1936/1997.

29 Voegelin, 1952, 79.

30 Wimmer and Schiller, 2002.

31 Könönen, 2014a, 18.

32 Anderson, 2019.

33 De Genova, 2005, 57-58; Könönen, 2014a, 18; Sager, 2016.

34 Könönen, 2014b, 188.

35 Amelina and Faist, 2012.

36 Anthias, 2020, 141-146; Anderson, 2019.

37 Amelina and Faist, 2012.

38 Wimmer and Schiller, 2002; Sager, 2016.

39 Könönen, 2012.

40 Hall, 2002, 16.

41 Wimmer and Schiller, 2002, 325.

42 Sayad, 2004, 278.

43 Könönen, 2014a, 18-19; Nissilä, 2016, 60.

44 Könönen, 2014a, 19.

45 Amelina and Faist, 2012.

46 Amelina and Faist, 2012, 1707.

47 Massey, 1993; Kymäläinen, 2006, 206-210.

48 Amelina and Faist, 2012.

49 Anthias, 2008.

50 Amelina and Faist, 2012.

51 See e.g. Marcus, 1995.

52 Nissilä, 2016, 62.

53 Amelina and Faist, 2012.

54 Anthias, 2008.

55 See e.g. Paasi, 2001; Beck, 2006.

56 Anthias, 2008.

57 Massey, 1991, 24-29.

58 Könönen, 2014a, 19.

59 Laine, 2016.

60 Anthias, 2020, 141-144.

61 Anderson, 2019.

62 Anthias, 2008, 8.

63 Anthias, 2008, 9; 2020.

64 Mengiste, 2018.

65 Donna Haraway, 1988.

66 Haraway, 1988, 583, 589.

67 Haraway, 1988, 592.

68 Mengiste, 2018.

69 Treiber, 2013; Mengiste, 2018; Sanchez and Natividad, 2017.

70 Mengiste, 2018, 63.

71 Mengiste, 2018.

72 Voegelin, 1930/2003, 463-464.

73 Anthias, 2008.

74 Shinozaki, 2012.

75 Mohanty, 1991.

76 Shinozaki, 2012.

77 Shinozaki, 2012. 


\section{References}

Adams, Ian. 1993. Political Ideology Today. Manchester: Manchester University Press.

Amelina, Anna, and Thomas Faist. 2012. "De-Naturalizing the National in Research Methodologies: Key Concepts of Transnational Studies in Migration.” Ethnic and Racial Studies 35, no. 10: 1707-24.

Anderson, Benedict. 1983/2016. Imagined Communities: Reflections on the Origin and Spread of Nationalism, 4th ed. London: Verso Books.

Anderson, Bridget. 2019. "New Directions in Migration Studies: Towards Methodological De-Nationalism.” Comparative Migration Studies 7, no. 36. doi: 10.1186/s40878-019-0140-8.

Anthias, Floya. 2008. "Thinking Through the Lens of Translocational Positionality: An Intersectionality Frame for Understanding Identity and Belonging." Translocations 4, no. 1: 5-20.

Anthias, Floya. 2020. Translocational Belongings: Intersectional Dilemmas and Social Inequalities. London: Routledge.

Beck, Ulrich. 2006. The Cosmopolitan Vision. Cambridge: Polity Press.

Billig, Michael. 1995. Banal Nationalism. London: Sage.

De Genova, Nicholas. 2005. Working the Boundaries: Race, Space, and "Illegality" in Mexican Chicago. Durham: Duke University Press.

Duhem, Pierre. 1906/2007. La Théorie Physique: Son Objet, Sa Structure. Paris: Vrin.

Freeden, Michael. 1998. "Is Nationalism a Distinct Ideology?" Political Studies 46, no. 4: 748-65.

Gellner, Ernest. 1983. Nations and Nationalism. Ithaca: Cornell University Press.

Hall, Catherine. 2002. "Introduction." In Civilising Subjects: Metropole and Colony in the English Imagination, 1830-1867, edited by Catherine Hall, 339-50. Cambridge: Polity.

Haraway, Donna. 1988. "Situated Knowledges: The Science Question in Feminism and the Privilege of Partial Perspective." Feminist Studies 14, no. 3: 575-99.

Hayek, Friedrich. 1949. "The Intellectuals and Socialism." The University of Chicago Law Review 16, no. 3: 417-33.

Könönen, Jukka. 2012. "Tutkimuksen Politiikka: Metodologisesta Nationalismista Muuttoliikkeiden Autonomiaan." Liikkeessä Yli Rajojen blog series. Accessed April22,2020.https://liikkeessaylirajojen.fi/tutkimuksen-politiikka-metodologisestanationalismista-muuttoliikkeiden-autonomiaan/

Könönen, Jukka. 2014a. "Tilapäinen Elämä, Joustava Työ: Rajat Maahanmuuton Ja Työvoiman Prekarisaation Mekanismina." PhD diss., University of Eastern Finland.

Könönen, Jukka. 2014b. "Pidätelty Elämä. Rajat Prekaarisuutta Tuottavana Instituutiona." Oikeus 43, no. 2: 171-91.

Kramer, Lloyd. 1997. "Historical Narratives and the Meaning of Nationalism." Journal of the History of Ideas 58, no. 3: 525-45.

Kymäläinen, Päivi. 2006. "Paikan Ajattelun Haasteita.” In Paikka: Eletty, Kuvattu, Kerrottu, edited by Seppo Knuutila, Pekka Laaksonen, and Ulla Piela, 203-17. Jyväskylä: Suomalaisen Kirjallisuuden Seura.

Laine, Jussi. 2016. "The Multiscalar Production of Borders." Geopolitics 21, no. 3 : 465-82.

Mannheim, Karl. 1929/1954. Ideology and Utopia. London: Routledge.

Marcus, George. 1995. "Ethnography in/of the World System: The Emergence of Multisited Ethnography." Annual Review of Anthropology 24: 95-117. 
Martins, Herminio. 1974. "Time and Theory in Sociology." In Approaches to Sociology: An Introduction to Major Trends in British Sociology, edited by J. Rex, 246-94. London: Routledge.

Massey, Doreen. 1991. “A Global Sense of Place.” Marxism Today 38: 24-29.

Massey, Doreen. 1993. "Power-Geometry and a Progressive Sense of Place." In Mapping the Futures: Local Cultures, Global Change, edited by J. Bird, B. Curtis, T. Putnam, and L. Tickner, 59-69. London: Routledge.

Mengiste, Tekalign Ayalew. 2018. "Refugee Protections from Below: Smuggling in the Eritrea-Ethiopia Context." The Annals of the American Academy of Political and Social Science 676, no. 1: 57-76.

Mohanty, Chandra. 1991. "Under Western Eyes: Feminist Scholarship and Colonial Discourses." In Third World Women and the Politics of Feminism, edited by Chandra Mohanty, Ann Russo, and Lourdes Torres, 51-80. Bloomington: Indiana University Press.

Nissilä, Hanna-Leena. 2016. “"Sanassa Maahanmuuttaja On Vähän Kitkerä Jälkimaku”: Kirjallisen Elämän Ylirajaistuminen 2000-luvun Alun Suomessa.” PhD diss., University of Oulu.

Paasi, Anssi. 2001. "Europe as a Social Process and Discourse: Considerations of Place, Boundaries and Identity." European Urban and Regional Studies 8, no. 1: 7-28.

Sager, Alexander. 2016. "Methodological Nationalism, Migration and Political Theory." Political Studies 64, no. 1: 42-59.

Sanchez, Gabriella, and Nicholas Natividad. 2017. "Reframing Migrant Smuggling as a form of Knowledge: A View from the U.S.-Mexico Border." In Border Politics: Defining Spaces of Governance and Forms of Transgressions, edited by Cengiz Günay, and Nina Witjes, 67-83. Cham: Springer.

Sayad, Abdelmalek. 2004. The Suffering of the Immigrant. Cambridge: Polity.

Shinozaki, Kyoko. 2012. "Transnational Dynamics in Researching Migrants: Selfreflexivity and Boundary-drawing in Fieldwork." Ethnic and Racial Studies 35, no. 10: $1810-27$.

Smith, Anthony. 1983. "Nationalism and Classical Social Theory." British Journal of Sociology 34, no. 1: 19-38.

Thompson, Andrew, and Ralph Fevre. 2001. "The National Question: Sociological Reflections on Nation and Nationalism." Nations and Nationalism 7, no. 3: 297-315.

Treiber, Magnus. 2013. "Lessons for Life. Two Migratory Portraits from Eritrea." In Long Journeys: Lives and Voices of African Migrants on the Road, edited by Alessandro Triulzi, and Robert McKenzie, 187-212. Leiden: Brill.

Voegelin, Eric. 1922a. "Interaction and Spiritual Community." In The Collected Works of Eric Voegelin, vol. 32, 19-140. Columbia: University of Missouri Press.

Voegelin, Eric. 1922b. "The Social Determination of Sociological Knowledge: A Sociological Examination." In The Collected Works of Eric Voegelin, vol. 7, 27-48. Columbia: University of Missouri Press.

Voegelin, Eric. 1925/2003. “On Max Weber.” In The Collected Works of Eric Voegelin, vol. 7, 100-17. Columbia: University of Missouri Press.

Voegelin, Eric. 1930/2003. "National Types of Mind and the Limits to Interstate Relations." In The Collected Works of Eric Voegelin, vol. 32, 430-82. Columbia: University of Missouri Press.

Voegelin, Eric. 1934/2001. "Drafting a Constitution for Austria." In The Collected Works of Eric Voegelin, vol. 9, 23-7. Columbia: University of Missouri Press.

Voegelin, Eric. 1936/1997. Der Autoritäre Staat. Vienna: Springer. 
Voegelin, Eric. 1952. The New Science of Politics. Chicago: University of Chicago Press.

Weber, Max. 1919/1946. "Politics as a Vocation." In From Max Weber: Essays in Sociology, edited by Hans Heinrich Gerth, and Charles Wright Mills, 77-128. New York: Oxford University Press.

Weber, Max. 1922/1968. Economy and Society. Berkeley: University of California Press.

Wimmer, Andreas, and Nina Glick Schiller. 2002. "Methodological Nationalism and Beyond: Nation-State Building, Migration and the Social Sciences." Global Networks 2, no. 4: 301-34. 


\title{
2 Refugee and migrant knowledge as historical narratives
}

\author{
Prem Kumar Rajaram
}

In this chapter, I think about knowledge of and by refugees and migrants ${ }^{1}$ in relation to historical problems about how community, identity, belonging, value and responsibility are determined (usually in terms of the stable concept state-nation-community). The triad state-nation-community gives rise to stable concepts, including those of "refugee" and "migrant", that would not exist without the historical concretisation of state-nation-community as the hegemonic form of political community and the ways of seeing and knowing that come from it and help to order our world. The historical contingency of this triadic political community is often difficult to uncover, concealed as it is by political practices and discourses that normalise and ahistoricise it. The consequence is that we often deal with concepts and not with the historical contests that led to their emergence. With the nation-state-community as a foundation, a number of complex historical-social relations are left concealed and not analysed. I will argue in this essay that by looking at issues about knowledge and ways of knowing as they relate to refugees and migrants, we are able to move beyond these stable and ahistorical conceptualisations of human mobility and the hegemonic ideas of political community on which they rely. Knowledge production for and about refugees has the capacity to challenge deeply engrained structures of domination, but I would argue they do so only if they begin from a perspective that sees refugees as contemporary manifestations of historical problems about how to imagine community, belonging, identity, responsibility and value that have been reconciled in the stable concept state-nation-community.

How are these complex historical-social relations concealed? One important way is by devaluing alternative histories and forms of knowledge. In this chapter I will look at the persistence of a type of "coloniality of power" 2 which acts against what may be called "subaltern" narratives. Such narratives are devalued because they are said to not be relevant for the contemporary world or for modernity or some other large hegemonic idea. This leads to the stability of ahistorical concepts, like the triad state-nation-community, and the ways of imagining and governing that stem from them.

In this chapter, I try to recover subaltern narratives. In order to do that, I look at the social and political impacts of two contested practices of knowledge by people identified as migrants. The first example is the politics

DOI: $10.4324 / 9781003092421-4$ 
and narratives by migrant workers in a tea-growing district in colonial India in the early 20 th century. I read these as attempts to produce new knowledge about colonial-capitalist rule that challenged British narratives of the same. The colonial exploitation of migrant workers depended on a narrative strategy that would depict them as backward and thus justify their exploitation on low wages in a labour regime based on heavy discipline, control and surveillance. As I will argue later, the value of colonised people's labour was not worked out in the labour-capital relationship, but outside it in the racist everyday of the colony. The maintenance of the ruse of "free labour" by colonial administrators made a fetish of the capital-labour relation, it became the focus of administration, and in the postcolonial state it underpinned political claims and the idea of citizenship. ${ }^{3}$ The idea of administrable "labour" gave colonised people a place in a regimented and hierarchical polity and was generally the first way of administering the colonised subject. The histories of antagonism and conflict that led to the labour relation forming in a particular way became obscured.

My second example is a discussion of issues faced by displaced people seeking entry into higher education in Europe. The connection between the two cases is the way value is imputed on subaltern others outside of the ostensibly primary value regime (in the first case, the labour-capital regime, in the second the higher education assessment system). The labour market is important to both cases, with the latter story being about people whose claims on knowledge and knowledge production are juxtaposed against European labour markets' need for cheap and disposable labour (see Bergholm and Toivanen in this volume). ${ }^{4}$ There remain individuals whose market value is not determined by their bodypower alone but by their evictability. I will argue that migrants and refugees are valued as evictable individuals and groups, but not as producers of knowledge with the consequence that there are few pro-active attempts to enhance university education.

Many, but certainly not all, citizens have the privilege of being assessed as potential students, in a relationship which assesses only the extent to which they fit previously stated entry requirements. This assessment system has class and other bias built in; 5 this points to the fact that the capacity of some citizens to become students is dependent on social relations outside the system. For displaced people in Europe, the social relations outside the system have an overwhelming impact on their chances of being students. This is not to say this experience is worse than that of citizens impacted by implicit or explicit class or other bias in university admissions. The idea of the coloniality of power traces how hegemonic systems, which can appear to be "neutral" or "fair", are based on invisibilising social relations of inequality that impact on access to social goods, in this example the university. A primary way, I argue, that the coloniality of power works, is by a prior derogation of the value of some experiences. The value of subaltern groups is not articulated solely or even primarily within the ostensible value regime applied to. With regards higher education, as Paolo Freire argues, ${ }^{6}$ there is a pre-emptive dismissal of the possibility of alternative ways of knowing: these cannot be valued within 
the typical higher education system and its admissions policies. The other side of this is that "othered" groups carry this value into a myriad of relations. Thus refugees and displaced people in Europe bring with them the imputation of otherness into different relations, including that of higher education: the border is multiple and invasive. ${ }^{7}$

What may be called state or state-centric knowledge about refugees in Europe is bulwarked by data and research that naturalises the state and its political arrangements. Framed differently for different audiences, the European Commission centres its narrative and knowledge about refugees through the prism of smuggling and security risks (see Bergholm and Toivanen in this volume). ${ }^{8}$ These are modes of representing human mobilities, with an overarching master frame which is the centrality of a settled notion of state-community-nation. Pro-migrant media representations have been recently critiqued as being eurocentric because they do not connect "migration crisis" to continuing coloniality. ${ }^{9}$ Critical readings of migration that call to mind new agglomerations of solidarity and responsibility do not always root themselves in the historical work necessary to say what experiences these terms ("state", "nation", "community") conceal. ${ }^{10}$

The primary focus of this essay is then on two cases intended to demonstrate (1) the way the coloniality of power works, and (2) what may happen when we take seriously alternative narratives of migrants - as subaltern others: might we be able to move beyond the organising concepts of our contemporary world, and indeed the exclusions and violence that it causes? Before turning to the two cases, the essay starts with a brief engagement with the thought of Michel Foucault ${ }^{11}$ and Raymond Williams. ${ }^{12}$ Foucault's account of the contests between subjugated and dominant knowledge seems to me to connect to Williams' conjunctural histories which focuses on the multiple entanglements that have been invisibilised under concepts like state-nationcommunity and the political practices that they justify. Such conjunctural histories also point to alternative futures, different ways of organising political community and responsibility that are actively derogated by hegemonic systems. Migrant and refugee knowledge is one such alternative.

\section{Multiple histories}

The state-centric policy regimes that refugees typically have to negotiate reflects complex historical experiences that are concealed. In Europe, terms like state, nation, community reflect (but also conceal through ideological work) a complex cultural and political historical experience tying in colonialism and capitalism. So do the value systems that operate within the state-nation-community and which generally go by labels like "economy" and "culture" and the "political system". Knowledge production by subaltern groups may denaturalise the statenation-community triad and the ways of seeing and thinking they encourage.

Dissident ways of thinking and seeing human mobility can run the risk of being isolated and fragmented against this solid architecture. In Europe, a populist rhetoric to connect "state", "nation" and "community" has been 
used. ${ }^{13}$ An important consequence of this is a culturalisation of the public sphere with the European Union and individual member states pronouncing threats to European ways of life posed by migrants: people on the move become security threats.

Alternative ways of seeing and understanding refugees and migrants might seem to resonate with Michel Foucault's description of "local critique". ${ }^{14}$ "Local critique" is the action of subjugated knowledge. Foucault describes local critique as a response to the universalising and generalising tendencies of "established regime[s] of thought". Foucault therefore gives "subjugated knowledge" the role of demonstrating the limits of the theoretical unity of dominant knowledge by pointing to the fragments and remnants that have not been successfully or finally encompassed. The value of Foucault's typology is that the emphasis is placed on the relations between subjugated and dominant knowledge, allowing a focus on how hegemonies require the policing of alternative ways of knowing. The limitation of Foucault's approach is that the historicity of the relations between dominant and subjugated knowledge is not explicitly connected in the way, for example, Raymond Williams attempts in his account of dominant, residual and emergent cultural forms. ${ }^{15}$

To focus on local critique in its relation with dominant knowledge is to focus on the historical experiences behind stable terms (state-nation-community) rather than naturalise, take for granted, or leave unchallenged the politics and ways of thinking enabled by these terms. This applies to dominant knowledge about refugees. Raymond Williams argues that if we move beyond the names and concepts, we see a series of historical problems, in this case problems about how we live together and how we are to be governed. ${ }^{16}$ If, Williams continues, we see concepts as actually being historical problems that are as yet unresolved, then there is little sense in "listening to their sonorous summons or their resounding clashes". ${ }^{17}$ What, Williams asks, might it look like to move beyond concepts and to recover the historical experience from which these concepts were cast? To my mind, this means questioning the assumptions of state-community-nation thinking about refugees. It is about focusing on the historical antagonisms that have been reconciled under ostensibly stable concepts.

In other words, it means uncovering the historical experiences underpinning what we commonly understand as refugee experience or, sometimes, "refugeeness". This is more incisive than juxtaposing alternative knowledge about refugees against dominant ones. Such juxtapositions do not necessarily connect refugees with broader historical experiences that the concept statenation-community conceals.

People called refugees are the subject of an ideological interpellation that separates them from the state-nation-community. This separation is validated to the extent that state-nation-community are taken as stable concepts that can direct how people live together. The onus then is to recover the substance, the historical relations and experiences, from which these stable concepts were cast. Alternative knowledge about or by people called refugees is at its most striking when read as markers of these complex historical relations. This means reading knowledge about or by people called refugees not as 
"refugee knowledge", but as expressions of a condition of marginalisation or subjugation that has historically been important in stabilising the concepts we use to arrange how we live together and are governed (state-communitynation). I will argue that it is the continued expression of the coloniality of power, better read as a historical process of cultural, political and economic expansion built on subjugation and value-derogation that manifests in occupation of territory. This coloniality of power continues to be important in understanding contemporary processes of exclusion and subjugation on which the state-nation-community triad and dominant narratives about refugeeness rest.

Moving away from epochal thinking, with its emphasis on understanding a system that has dominant features, ${ }^{18}$ colonialism is better understood as the historical expression of a project of expansion that involves cultural, political and economic appropriations. The result is that difficult questions of living together and being governed become stabilised into concepts that conceal the historical problems from which they were cast. By associating refugee knowledge with indigenous narratives against "colonialism", I point to the coloniality of refugee and migrant governance in Europe.

\section{Exile, labour and knowledge: tea plantation workers in colonial India}

British colonial expansion in India involved reorganising ways of living. An important aspect of this was the use of disciplinary and legal measures to transform people into labourers and ensure their reproduction. It is crucial that the price of labour was not determined according to traditional market forces. Value was attributed outside the employer-labour relation. Colonised people had their bodypower "cheapened" based on the attribution of cultural inferiority. "Labour" was, and is, a cultural system: it is a way of organising bodypower so that it is productive. To be productive, in the colony, was to work according to what were taken to be European norms, and colonised subjects were always presumed to fall short of such cultural norms, being too traditional or too bound by custom or simply too lazy to approximate to the standards of "labour". ${ }^{19}$ This justified the cheapening of the bodypower of colonised subjects. The value of labour was determined outside of the actual contractual relationship between capital and labour; this suggests that capitalist production was nested in wider racist social and cultural relations.

These wider relations point to the antagonistic historical experiences that are resolved and forgotten under ostensibly stable arrangements like the market and "free labour". The validation of colonial power rested on a prerogative to narrate historical experience in any given space, and to block other narratives from emerging. ${ }^{20}$ The prerogative to narrate rested on the capacity to construct a homogenous norm out of a complex culture ("European" or "English") and the prerogative to control other narratives lay in the elevation of that "culture" to civilisation itself, and the consequent tethering of "native" to "European" where the latter represented order and civilisation and the former its dark mirror always playing catch up but doomed to never quite get there. ${ }^{21}$ 
The fairly simple point that value was attributed outside of the capital-labour relation allows us to shed light on the historical relations and experiences from which stable concepts were cast. ${ }^{22}$ The capacity to control the narration of these experiences takes the form of Orientalist rewriting of native experience and the incorporation of these into a colonial hegemony. While Foucault focuses on local critique, Williams' conjunctural critique points to the histories of accumulation and dispossession on which hegemony lies. Hegemonies appropriate alternative narratives of human experience and use them to justify and validate a specific way of thinking - a culture - and, therefore, economic, political and social organisation. One result then is that the value of the bodypower of native labourers is determined in relation to a narrative that casts them as inferior.

Williams' focus on how hegemonic cultures are formed is intended to move beyond epochal historical analysis - it is not colonialism that is the subject, and it is not the point that colonialism (or any other cultural form) may have had determining dominant features. The focus is rather on the historical experiences and processes rather than the concepts that derive from them. It is important, according to Williams, to focus on the complex interrelations between historical movements and tendencies. ${ }^{23}$

Williams emphasises that hegemonies are in relations of struggle with residual cultural forms that it cannot quite do away with, and with emergent cultural forms that arise and sometimes deviate from the hegemonic. To recover these relations of struggle that are invisibilised by stable concepts, we may point to contradictions in the ostensibly stable systems, for example in the colonial market economy where labour is valued not in terms of the capital-labour relationship. Such contradictions point to how apparently stable concepts bleed out to connect with complex historical experiences and the struggle to control narratives about these experiences.

\section{Narratives of migrant workers in colonial India}

In what follows I tell a story about narratives by indigenous labourers in a tea plantation in colonial India and the attempts by British authorities to reframe their articulations and opposition to a system of colonial-capitalist exploitation.

Jalpaiguri in northeast India was one of the centres of tea production in colonial India. Labourers included indigenous Oraon "tribals" recruited from Chota Nagpore (Chotanagpur in the current spelling) some $500 \mathrm{~km}$ to the south-west. In 1916, when our story began, there were in the region of 90,000 migrant tea workers from Chota Nagpore in and around Jalpaiguri.

The law - the Inland Emigration Bill - called them free workers, and colonial ethnographers called them tribals. Oraons had moved to work in tea estates in north-east India since the 1870s, with numbers escalating in the late 19th and early 20th century because of famine or food shortage, land enclosures and high taxation. The Inland Emigration Bill fostered their mobility, but the fundamental cause of this was the encroaching of capitalist modes of production that meant participating in a capitalist labour market - i.e. learning to perceive and mobilise one's "labour power" with regards to the new economic structures 
- was the only option for survival and reproduction. Unlike labourers in nearby Assam who were primarily indentured, Oraon labourers were largely contracted and because of this a rhetoric that they were "free labour" prevailed. It is important to note though that like the indentured system, the contracting of Oraon "tribals" was designed not so much as to provide economic choices for the labourer, but to secure for planters a labour force whose wages "were determined completely outside the labour market". ${ }^{24}$

Behal and Mohapatra's argument is focused on indentured labourers in Assam and against liberal revisionist historians who emphasise freedom of contract and mobility for indentured labour. Indenture meant that individuals were not free to collectively organise nor to withdraw from the labour contract. The same outcomes were caused among "free labourers" in Jalpaiguri not tied to an indenture contract. Wages paid to tea plantation workers were half that paid to agricultural workers in the district, Oraons were migrant workers recruited to provide cheaper and more disposable labour than the market conditions of the district allowed. The reproduction of this labour force was enabled by close connections with recruiters and middle men and the availability of a surplus labouring population who had not yet migrated. Their interaction with the higher-paid agricultural workers was strictly limited by a hierarchical and highly disciplinary plantation management. ${ }^{25}$ Their lack of connections to the wider society emphasised their evictability, limited their opportunities for social reproduction and enabled the maintenance of artificially low wages. The reproduction of the labour force was managed by the planters through importing more migrant workers, rather than through traditional social reproduction. The consequence was a downward pressure on wages and the ability to control any attempts at unionising or organising.

The situation of Oraons as migrant workers in the Duars has strong similiarites to that of refugees and migrants today who work as disposable and evictable labour in market conditions and for wages that are significantly lower than much of wider society. The same goes for low wages paid to citizens on zero-hour contracts, market innovations that enable a separate sub-market for the bodypower of individuals who cannot valourise their labour under normal market conditions. ${ }^{26}$ These are not new "neoliberal" innovations, but a natural consequence of the availability of a marginalised population.

One important way in which colonial capitalism controlled labour and artificially low wages were through narratives that constructed a stable and exploitable labour force out of indigenous labour. The experiences of encroachment, enclosure and dispossession were invisibilised by a colonial economy that deployed a cultural sensibility of bringing modernity to backward groups. The low wages determined outside of market conditions were also enabled and maintained by a culturalist discourse, one that deployed an Orientalist view, backed up by ethnographers. This took many forms for different groups, Oraon for their part were characterised as "jungli" from "jungle", valued for hardy bodies but tagged to primitivity. ${ }^{27}$

The cultural narrative would have it that Oraons were controllable, simple coolies, and some historical texts also miss contrary evidence. Despite 
attempts to ensure separation between Oraon tea plantation workers and other agricultural workers, a 1910 report was full of accounts of labourers "running away", often with wage advances to set up more independent lives in the surrounding agricultural communities. ${ }^{28}$ The typical way of understanding this by progressive scholars is to point to a struggle against deproletarianisation..$^{29}$ However, the other point is that planters with the assistance of the colonial government sought actively to control the narratives of Oraon about their own historical experiences. Their narratives and ways of knowing and understanding their contemporary situation caught up by colonial-capitalist rule were actively denigrated and dismissed.

An excellent example of this was the response by the British authorities and planters to incidents in 1916 when Oraon labourers rioted. Police reported masses of Oraon men gathering to sing songs at night and refusing to work. These songs and verses called on Kaiser Wilhelm to come and save the Oraons from the injustices of colonial and zamindari rule, to kill the British and establish an Oraon Raj. Things kicked off and the local government became involved when a "tea garden" worker named Charua Oraon cut his wife's throat and then his own after being made to chant "the name of the Germans" by some of his fellow labourers. Before he died, he told the investigating policeman that some of his fellow tea workers were trying to make him recite something, saying that a devil named Logo would come and kill him and his wife if he refused. Soon after their deaths, tea estate managers reported a series of stop work protests and groups gathering at night to sing songs and chant verses. ${ }^{30}$

To take up some space to record this song is important, these are the subjugated narratives of people trying to articulate the historical experience of dispossession that is colonialism and resisting the large concepts centring around British order and civilisation. The song was sung by one Soma Oraon, before the magistrate and translated by a member of the investigating tribunal:

German Baba is coming

Is slowly slowly coming

Drive away the devils Manaldanal;

Cast them adrift in the sea,

Suruj Baba (the Sun) is coming;

The devils of the Oven will be driven away

And cast adrift in the sea.

Tarijan Baba (the stars) is coming,

Is slowly slowly coming,

Is coming to our very courtyard,

The chigri devils will be driven away

And cast adrift in the sea. ${ }^{31}$

It was the middle of World War One and the Tribunal was tasked to determine the cause of this "seditious" activity and to find out if German Lutheran missionaries were behind the songs extolling the Kaiser - "the German Baba". 
Towards the end of the 19th century and in the early 20th, Oraons in Chota Nagpore were rent by a series of pseudo-millenarian movements. One stuck - the Thana Bhagat movement which, according to colonial administrators and ethnographers, combined personal and moral teachings with political and economic claims. Members of the Thana Bhagat movement ("Thanas") were called on to stop eating meat and drinking alcohol and Christian or Muslim Oraons were excluded from membership. Members were enjoined not to till fields and to spare the suffering oxen. Protests and demonstrations against high taxation and the excesses of the zamindari ${ }^{32}$ system grew. In the early 20th century, the British called in their Gurkhas and a brief skirmish occurred. The movement stalled at that point. I have not been able to find any record of the skirmish with the Gurkhas, authorities mention it in passing but no record of what happened seems to exist, and no history of the Thana Bhagat movement mentions this. In 1915, in the tea gardens in Bengal and Assam where Oraon workers had migrated, the movement appeared to suddenly come to life in bursts.

The Tribunal's conclusions were centred on grasping the narrative away from the Oraons. Despite evidence that the invocation of Kaiser Wilhelm to save Oraon from the British and to kill the colonialists had clear connections to the previous Thana Bhagat movement (leaders of this uprising in 1916 were involved in that movement), the Tribunal would conclude that, despite having no evidence at all, that German missionaries were behind the uprising. The Tribunal concluded: "The Commission who tried the case held that no German missionary could have been concerned, since Christian Oraons were excluded from the meetings. But some German agent, or some agitator or impostor must have been at the bottom of it... There is no anticipation of further trouble." 33

The British ethnographic narrative about Oraon insisted that they "are mere coolies, and of a race prone to superstition and the wildest stories" and could not have come up with an account of British oppression without German intervention. This is against the evidence of the Thana Bhagat and millenarian movements that had disturbed the colonial social order in Chota Nagpore and now imported into Jalpaiguri and the Duars. The culturalist rendition of the Oraon as mere coolies, incapable of articulating political agency without external (German, European) intervention, was necessary as a means of controlling narratives about historical experiences. Following Raymond Williams, the ability to make invisible alternative historical experience enables the articulation of stable concepts and to assert the hegemony of particular ways of knowing.

I have tried in this section to recover residual histories, attempts to give a different narrative about the colonial-capitalist experience. These narratives point to the antagonistic historical experiences that are prevented from emerging by a culturalist narrative. This culturalist narrative forecloses the possibility of these alternative experiences emerging by naming their proponents as backward or primitive and incorporating them into a cultural system in the colony that tethered native knowledge to European modernity as their dark mirrors. 


\section{Knowledge production and contemporary migrants}

In this section I focus on access to higher education for people called refugees in Europe, this is a story about contests over knowledge and knowledge production and about the value of disposable labour to capitalist systems.

Following the arrival of over a million new refugees and migrants in Europe in 2015, the European Union and individual member states attempted to increase opportunities for migrants and refugees to access higher education, often as part of a broader suite of European and national policies designed to either foster integration or assuage the threat of radicalisation..$^{34}$ Several strategies formed part of this overall policy. The EU promoted mechanisms to assess and recognise migrants' and refugees' qualifications; states and individual universities set up scholarship programmes and language courses. While these measures aimed to address some of the difficulties that refugees faced in accessing higher education, they typically do not deal with the underlying political and social issues influencing how refugees are perceived and governed in Europe. That is to say, these new - and often innovative-measures stem from and reiterate the European integration infrastructure that sees refugees as cultural others.

This problematisation manages potentially disruptive social forces. Governmental framing facilitates viewing refugees, like other subjects of the state, in terms of the problems that they pose to government; governmentalised subjects are reduced to how the state or other authority perceives them. Foucault notes that this means that the historical depth and character of people and groups become reduced to questions of systemic organisation and rule. In Raymond Williams' terms, it could be said that in order to preserve the state-nation-community concept, people called refugees are interpreted as specific sets of problems for government, and their entrance or otherwise into higher education is determined by this interpretation.

Against this framing of refugees as a particular type of problem, I argue that refugees may be understood as a group whose social and economic marginalisation shares similar features to the marginalisation of other communities in Europe. This is sometimes along the lines of class, and other times along the lines of religion or ethnicity. ${ }^{35}$ Focusing on the common marginalisations of refugees and others offers an opportunity to rethink how higher education access for refugees may be framed. Rather than a governmental means to ensure that refugees "fit", the issue may be re-situated to something like this: how would the entry into university of marginalised groups (including people problematised as "refugees" requiring integration) aware of the historical conditionality of their marginalisation help us rethink the relationship of universities to education and the role of the university in the public sphere? University admissions, as noted earlier, reflect broader social relations, and this acts as a way of filtering out dissident ways of thinking. The value of certain groups, refugees among term, is formed in the broader social relations which are carried with them across different social relations and value regimes, the university admissions system being one. 
Henry Giroux has argued that the "fundamentally political nature" of university teaching has been downplayed in western states over time. ${ }^{36}$ The university, he argues, can become at times an adjunct to the market, providing education that is in service to existing employment opportunities, thus reproducing inequalities. The reproduction of social and economic inequalities serves the interests of an elite and enables their control over state infrastructure while also then continuing the relative marginalisation and inequality of different groups defined in racial/ethnic, gender or class terms. Giroux argues that it is important to consider the role that pedagogy and curricula have in furthering or impeding social change. Thinking about refugees as a marginalised group, and not an externalised appellant to the state as the governmental narrative would have it, might allow us to think the fuller import of critical pedagogic and inclusive practices at universities and how these may foster broader social inclusion.

Shahram Khosravi ${ }^{37}$ argues that an impediment to refugees entry into higher education in Sweden is the imperative that they valourise their bodypower in the labour market. Migrants and refugees are important as people whose labour value can be calculated outside of market conditions. Like Oraon migrant workers, refugees and migrants sell their disposability and evictability. Cast as external others, refugees and migrants are regularly consigned to making fragile claims to belong and left with little but their bodypower to valourise, which means valourising their insecurity and reproducing conditions of evictability and disposability. ${ }^{38}$

The equality presumed in the state-nation-community is seen in the figure of the citizen. The fact that there are unequal struggles to enact citizenship rights amongst citizens is something that is downplayed by the deployment of the state-nation-community concept and its rhetoric of equality for all (citizens). The particular problem posed to the state-nation-community concept by the entrance of refugees and migrants, and their struggles to valourise their bodypower, is that it is a reminder of historical problems of incorporation and valuation of different subjects in an unequal social, economic and political structure. The state-nation-community concept plays down this material inequality.

Access to higher education for refugees is an issue that both the European Commission and grassroots organisations have focused on. But this has focused on a transformation of refugees into another governmental category: students with the requisite qualifications to enter into higher education. Qualifications may be seen as markers and reassurances that the student and their learning can be incorporated into the education goals of contemporary universities in Europe. The focus on assessing qualifications, rather than learning or actual levels of knowledge, can prevent displaced students from accessing higher education. In my own work at Central European University's Open Learning Initiative (OLIve), we encounter students who have either been told by national education authorities to return to lower grades of high school, despite having a high school qualification, or have had their qualifications under-recognised, so that a Bachelor's degree is not recognised as being 
adequate for graduate study. Initiatives to address these, like the Council of Europe's European Qualifications Passport, focus on making clear the qualifications that refugee students hold, they do not seek to overcome a focus on qualifications that are inevitably assessed as lower in value than that of European qualifications. This may be seen as an active form of de-skilling, where skills and learning gained in a different context and geography are devalued by bureaucratic processes of recognition.

This focus on qualifications and the under-valuing of non-European qualifications is a form of stabilisation and control of education, restricting the development of learning by groups that Paolo Freire (1970) calls the oppressed. As noted earlier, this restriction is enabled by the way in which such groups are valued in relation to cultural and social relations outside of the ostensible value regime. If we understand refugees and migrants not as governmentalised categories but as manifestations of historical problems about inclusion and valuation that have not been completely resolved, then we may argue that they represent remnants of the coloniality of power. In order to shed light on this coloniality of power, a principal focus would be perhaps in Freire's terms a form of pedagogy that focuses on problem-centred learning, moving away from names and concepts (here Freire and Williams are remarkably similar) towards an understanding of the historical conditions of oppression and exploitation that have led to certain forms of knowledge, and certain ways of knowing, and the interests they serve becoming dominant.

If refugees and migrants, and attempts to articulate dissident accounts of their experience, are taken as attempts to articulate historical problems that have been contained by the state-nation-community triad (like the Oraon migrant worker songs had to be contained by a colonial system), and if refugees are seen as manifestations of historical problems purportedly resolved, then the articulation of refugee knowledge should bring to light the limits and assumptions of the entire contemporary political and social edifice, the state-nation-community triad, and its value regimes.

\section{Conclusions}

In this chapter I have tried to insist that knowledge by and about refugees should be located in relation to a historical account of concepts that organise our political, economic and social life - state-nation-community. Following Raymond Williams, I have insisted also that we need to focus on the historical experiences and problems that have been invisibilised by these stable concepts. I have suggested that thinking about the contradictions of migrant and refugee experience can highlight the cracks in these concepts, focusing on the emergent and residual forms that hegemonies have not quite done away with.

Oraon migrant workers of the early 20 th century tried to narrate their own experience of colonial capitalism. In doing so, the conditions for the perpetuation of the colonial-capitalist system - the availability of labour whose price was not determined according to market conditions - would be threatened. 
Lower than market wages for Oraon migrant workers could only be paid if the colonial authorities could continue to justify the Oraon's backwardness. Thus, in the case I looked at, the colonial authorities had to dismiss the possibility of Oraon political agency; they had to remain "mere coolies" of a "superstitious race". The colonial tribunal insisted that political riots and protests by Oraon had to have been the result of mischief caused by German missionaries despite having no evidence for this. The sense of Oraon, and other people who could be exploited for their bodypower, as backward "mere coolies" was central to the racialised cultures of the colonial period. Without this, the figure of the native as the counterpart of the orderly and civilised European, to be simultaneously exploited for economic gain and civilised, would be called into question and the whole colonial edifice potentially under threat, with the violence and brutality underpinning colonial government becoming resonant.

The role of the university in furthering the state-centric account of "refugees" as a problem of governance was also investigated. Thinking about people called refugees not as external others would, however, mean that they may be understood as remnants of historical experiences of antagonism and conflict from which stable concepts that generate specific ways of living and value regimes (like state-nation-community) are cast. Like Oraon migrant workers, refugees present a historical problem that can show up the contradictions of how we live together, and the inequalities this validates. If understood as members of a commonly marginalised group that includes those both "inside" and "outside" the state-nation-community, then their externalisation as a problem of state is not valid.

The question of knowledge production for and by refugees and migrants is important. If we investigate it in relation to historical problems about how we live and with whom - rather than thinking it in terms of large concepts like state-nation-community - then a key focus must be how narratives and knowledge of these problems remain or may emerge. Hegemonies are maintained by the control of knowledge, that is, by the deployment of stable concepts - state, nation, community - rather than investigating problems. Knowledge production by and for refugees that is done in relation to these historical problems can demonstrate how hegemonies are not self-evidently dominant, they rely on struggles with residual and emergent ways of knowing that can, if given enough attention, be the basis of new forms of political action.

\section{Notes}

1 In this essay I use the terms "refugees", "migrants" and "displaced" interchangeably. "Refugee" is a legal category that does not cover the entirety of the experiences of forced displacement that people encoutner. Dichotomies between "refugee" and "migrant" are often false, while they may be subject to different legal regimes, their conditions and positions in relation to economic, political and cultural sytems are often similar. The best word might be "displaced", but it is unwieldy to use.

2 Quijano, 2000.

3 Rajaram, 2014.

4 Khosravi, 2019. 
5 Cantat, Cook, and Rajaram, Forthcoming.

6 Freire, 1970.

7 Khosravi, 2010.

8 Rajaram, forthcoming.

9 Avraamidou, 2020.

10 There are notable exceptions, see Mezzadra and Neilson, 2013; Cantat, 2016; Marfleet, 2006; Novak, 2017.

11 Foucault, 2003.

12 Williams, 1977.

13 Yılmaz, 2012; Rajaram, forthcoming.

14 Foucault, 2003, 6.

15 Williams, 1977, 121.

16 Williams, 1977, 12.

17 Williams, 1977, 12.

18 Williams, 1977, 121.

19 Alatas, 1977.

20 Said, 1993, xiii.

21 Fanon, 1967.

22 Rajaram, 2018.

23 Williams, 1977, 121.

24 Behal and Mohapatra, 1992, 143.

25 Bose, 1993, 96.

26 Rajaram, 2018.

27 Chatterjee, 2001.

28 Duars Committee, 1910.

29 Brass and Bernstein, 1992.

30 India Office Records, IOR/L/PJ/6/1448.

31 India Office Records, IOR/L/PJ/6/1448.

32 The land tenure system transformed by capitalism which allowed traditional owners of the land - zamindars - to exercise more proprietary rights to its produce than historically permitted, and to reduce those who worked the land to sharecroppers.

33 India Office Records, IOR/L/PJ/6/1448.

34 Rajaram, forthcoming.

35 Yildiz and De Genova, 2018.

36 Giroux, 2003, 6.

37 Khosravi, 2019.

38 Rajaram, 2018.

\section{References}

Alatas, Syed Husin. 1977. The Myth of the Lazy Native. New York: Routledge. Avraamidou, Maria. 2020. "The 'Refugee Crisis' as a Eurocentric Media Construct: An Exploratory Analysis of Pro-Migrant Media Representations in the Guardian and the New York Times." TripleC: Communication, Capitalism \& Critique. Open Access Journal for a Global Sustainable Information Society 18, no. 1: 478-493.

Behal, Rana P., and Prabhu P. Mohapatra. 1992. "Tea and Money versus Human Life': The Rise and Fall of the Indenture System in the Assam Tea Plantations 1840-1908." Journal of Peasant Studies 19, no. 3-4: 142-172.

Bose, Sugata. 1993. Peasant Labour and Colonial Capital: Rural Bengal Since 1770. Cambridge and New York: Cambridge University Press. 
Brass, Tom, and Henry Bernstein. 1992. "Proletarianisation and Deproletarianisation on the Colonial Plantation." Journal of Peasant Studies 19, no. 3-4: 1-40.

Cantat, Céline. 2016. "The Ideology of Europeanism and Europe's Migrant Other." InternationalSocialism 152.http://isj.org.uk/the-ideology-of-europeanism-and-europesmigrant-other/

Cantat, Céline, Ian M. Cook, and Prem Kumar Rajaram. Forthcoming. "Introduction." In Opening Up the University: Teaching and Learning with Refugees, edited by Céline Cantat, Ian M. Cook, and Prem Kumar Rajaram, New York: Berghahn Books.

Chatterjee, Piya. 2001. A Time for Tea: Women, Labor, and Post/Colonial Politics on an Indian Plantation. Durham: Duke University Press.

Duars Committee. 1910. Report of the Duars Committee. Shillong: Eastern Bengal and Assam Government Press.

Fanon, Frantz. 1967. Black Skin, White Masks. New York: Grove Press.

Foucault, Michel. 2003. Society must be Defended. London: Penguin.

Freire, Paolo. 1970. Pedagogy of the Oppressed. New York: Continuum.

Giroux, Henry A. 2003. "Public Pedagogy and the Politics of Resistance: Notes on a Critical Theory of Educational Struggle." Educational Philosophy and Theory 35, no. 1: 5-16.

Khosravi, Shahram. 2010. Illegal Traveler: An Autoethnography of Borders. New York: Palgrave Macmillan.

Khosravi, Shahram. 2019. "What Do We See If We Look at the Border from the Other Side?" Social Anthropology 27, no. 3: 409-424.

Marfleet, Phillip. 2006. Refugees in a Global Era. Basingstoke: Palgrave Macmillan.

Mezzadra, Sandro, and Brett Neilson. 2013. Border as Method, or, the Multiplication of Labour. Durham: Duke University Press.

Novak, Paolo. 2017. "Back to Borders.” Critical Sociology 43, no. 6: 847-864.

Quijano, Anibal. 2000. "Coloniality of Power and Eurocentrism in Latin America." International Sociology 15, no. 5: 215-232.

Rajaram, Prem Kumar. 2014. Ruling the Margins: Colonial Power and Administratice Rule in the Past and Present. New York: Routledge.

Rajaram, Prem Kumar. 2018. "Refugees as Surplus Population: Race, Migration and Capitalist Value Regimes." New Political Economy 23, no. 5: 627-639.

Rajaram, Prem Kumar. Forthcoming. "The Refugee Outsider and the Active European Citizen: European Migration and Higher Education Policies and the Production of Belonging and Non-belonging." In Opening Up the University: Teaching and Learning with Refugees, edited by Céline Cantat, Ian M. Cook, and Prem Kumar Rajaram, New York: Berghahn Books.

Said, Edward W. 1993. Culture and Imperialism. New York: Vintage.

Williams, Raymond. 1977. Marxism and Literature. Oxford: Oxford University Press. Yildı, Can, and Nicholas De Genova. 2018. "Un/Free Mobility: Roma Migrants in the European Union.” Social Identities 24, no. 4: 425-441.

Y1lmaz, Ferruh. 2012. "Right-wing Hegemony and Immigration: How the Populist Far-right Achieved Hegemony through the Immigration Debate in Europe." Current Sociology 60, no. 3: 368-381. 


\title{
3 Narratives on 'refugee knowledge' in the institutions of Europe
}

\author{
Bea Bergholm and Reetta Toivanen
}

\section{Introduction}

Europe does not see us as humans...

The European 'refugee crisis' of 2015 has been the focus of a vast amount of research in the past years. The topics have ranged from the false dichotomy of the 'economic migrant' versus the vulnerable 'refugee' and the politicisation of such categories, ${ }^{2}$ to migrants protesting against power and immobilisation practices by the Hungarian state, ${ }^{3}$ and to Europe's border security systems and their counter-productive effects. ${ }^{4}$ There is also some significant research on the role of European organisations and their usage of the term 'refugee crisis', as well as the surrounding narrative and its effects on European policies aiming to control the movement of migrants. ${ }^{5}$

In this chapter, we take the so-called refugee crisis as a background for looking at the different narratives on refugees that have been produced. We analyse how these narratives prevent European institutions from considering the refugees' own knowledge. The practice of ignorance towards the refugees' own forms of knowledge stems from a specific understanding of migration and refuge that concentrates on the lack of something, be it knowledge, skills, or even capability. Thus, when analysing the discourse of the 'refugee crisis', we conclude that the knowledge systems of refugees are not part of any narrative on refugees.

In this case, we use the term 'refugee knowledge' to refer to the overall knowledge, experience, and skills that refugees have prior to entering their new country of residence (see Björklund \& Kmak in this book). Refugee knowledge is usually defined in a very employment-centred way as the knowledge needed for successfully landing a job in the new host country. The focus is often on the absence of capabilities: lack of language skills, insufficient knowledge of bureaucratic processes, lack of cultural knowledge, etc. ${ }^{6}$ This does not allow for rethinking or reimagining what is meant with this knowledge when encountered with othered subjects. Kuhn and Jackson (2008) argue that knowledge, or what is recognised as knowledge, is communicatively constructed. ${ }^{7}$ In the case of refugees, communication regarding what kind of knowledge they possess is ignored, and instead the focus is on what is lacking. 
Language skills are often defined as knowledge of the official language(s) of the host country, such as Finnish or Swedish in Finland. Many refugees are fluent in several globally significant languages, such as Arabic or Farsi, but because these are not dominant languages in their new country, their 'lack' of language skills may pose a significant obstacle for employment. ${ }^{8}$ An important question is, how could we overcome this deficiency perspective and shift the focus to the existing multitude of capabilities that refugees have?

Problematising the concept of crisis itself - we use it as a context and frame for our analysis - it is possible to discern several different narratives regarding refugees, all of which function as a hindrance to recognising the refugees' own knowledge and hearing their voices. By unpacking each of these narratives, we demonstrate how they contribute to categorising refugees in stereotypical and harmful ways. Seeing refugees as valuable human beings with knowledge and skills risks being overshadowed by these problematic narratives, which are circulated and reproduced not only in the media but also within European institutions. Standardised, transnational visual and textual representations of refugees are easily shared across countries and institutions that administer refugee projects, and thus they have significant consequences. ${ }^{9}$

We argue that there is reason to suspect that European institutions do not adequately consider types of refugee knowledge. We seek to raise the question of whether disregarding refugee knowledge is intentional or whether it is about a lack of consideration and benign neglect. The main site of research is comprised by institutions within the European Union, although some attention is also paid to the Council of Europe. We have analysed a vast number of policy papers, travaux préparatoires, proposals, white papers, and news outlets. The amount of reports, policy briefs, journal articles, and scientific research on the specific moments of refugees entering Europe from 2015 to 2019 is overwhelming. ${ }^{10}$ For the purposes of this article, the reports published by the aforementioned European institutions (the EU and the Council of Europe) in the wake and aftermath of the 2015-2017 migration were the primary source for the analysis. The main interest was to investigate what kinds of roles the refugees were assigned in these reports and whether any of these roles took the expertise of the refugees into account. The core questions for the analysis are: What are the dominant discourses or narratives regarding refugee knowledge that are impacting European rhetoric, decision-making, and policymaking? In what ways do European institutions and organisations narrate and recognisze the knowledge of refugees? How do they acknowledge the knowledge and capabilities of the peole fleeing from elsewhere to the European continent?

\section{'Crisis' as the context for the narratives}

According to Bourdieu and Wacquant, critical research aims at discovering power relationships at work at a given moment. ${ }^{11}$ The years 2015 and 2016 can be called 'a moment' because the rising number of asylum seekers gave European governments a pretext to change their legislation and policies towards stricter border control and more rigid rules for granting asylum. The 
critical theory lens invites thinking of social identities as complex, changing, and discursively constructed, and it provides an alternative to essentialist conceptualisations of social groups and their identities. ${ }^{12}$ Using a critical theoretical frame, it can be argued that refugee knowledge is difficult to accommodate in the dominant paradigm, which only allows for very specific positionalities for refugees as individuals or groups of people. ${ }^{13}$ Thus, rendering a specific segment of society, such as refugees, as a problem supports essentialist governance practices that reproduce monolithic, linear, and self-sustaining actions towards them, instead of producing actual integration where both the host society and the refugee encounter and direct the actions to follow.

The word 'crisis' itself derives from the Greek word krino ('to cut, to select, to decide, to judge'). ${ }^{14}$ Following the definition of Murray Edelman, a crisis can be seen as a powerful political symbol, an analytical category, and a category of practice. Labelling something a crisis presents three claims:

(1) that the particular event or sequence thus labelled 'is different from the political and social issues we routinely confront'; (2) that it 'came about for reasons outside the control of political leaders'; [...] and (3) that it 'requires sacrifices in order to surmount it'. ${ }^{15}$

Crisis labelling has long roots, and it has been a standard practice for policymakers in the European Union ever since the end of the Cold War. ${ }^{16}$ Considered as a category of practice, crisis labelling enables and justifies new patterns of action to be taken; as Bourdieu states, labelling has a world-making capacity. ${ }^{17}$ In this text, we use the word 'crisis' in quotation marks to emphasise the dubious distinction between stability and crisis. 'Crisis' describes the hardships experienced by refugees and the situation which authorities and states faced, as they were inadequately prepared to receive the large number of people arriving in Europe in 2015-2016.

Taking the 'crisis' as a backdrop, it is possible to identify at least five different, though partially overlapping and even contradictory, narratives regarding refugees in European policy and media space. None of these narratives really give much space for the knowledge that refugees themselves already have. The first narrative sees refugees or migrants as the source of the 'crisis' and the problems Europe is facing. The second takes a managerial role in stressing how the 'flows' and 'streams' of refugees need to be controlled and managed. The third is describing the refugees as vulnerable objects that need to be taken care of; this applies especially to women and children, so that the fourth narrative, refugees as a potential security threat, is mainly applied to men. The fifth sees refugees as a potential source of help or even saviours for Europe in terms of a (cheap) labour force and means of correcting Europe's unbalanced age-dependency ratio. It is apparent that European institutions and organisations, despite their ampleness of differing agendas and purposes, took the media narrative surrounding the migrant movement as a given and did very little to challenge it. We will now unpack these five narratives and ask whether the knowledge of refugees is recognised in any of them. 


\section{Refugees as a source of the 'crisis'}

Reading the movement of people, or really any social phenomenon, as 'crisis' puts a frame around a complex social process and effectively separates it historically, socially, and politically from other social processes, non-crises. It creates a series of dualisms, where the 'crisis' is the less desirable mirror of a more orderly form of what is effectively the same phenomenon (mobility of populations). ${ }^{18}$

The first dominant narrative depicts refugees as the source for the 'crisis' in Europe, taking the concept of crisis as a given. However, the term 'crisis' itself requires scrutinising and critical theorisation. The situation in Europe has been termed a 'refugee crisis', a 'migrant crisis', a 'humanitarian crisis', a 'crisis of border control', and a 'crisis of the European asylum system'. ${ }^{19}$ Apart from the migrant situation, there has even been discussion about a larger 'crisis of Europe', referring to both the economic crisis of 2008 and the 'crisis of European democracy', as right-wing populist parties have gained support across Europe ${ }^{20}$ The declaration of a state of crisis has, in turn, served to justify new emergency policies and stricter border control at Europe's frontiers. The naming of something as a 'crisis' first legitimises the authorisation of exceptional or 'emergency' governmental measures, and then allows for their normalisation. ${ }^{21}$

We ought to ask ourselves some critical questions every time we encounter the word 'crisis': What 'crisis'? Whose 'crisis'? Who gains and who loses from the labelling of a 'crisis'? ${ }^{22}$ The Eurocentric focus on the global situation also steers attention away from social, political, and structural issues that have led to unsafe living conditions in certain areas and forced people to flee. Naming and classifying always involve exercising power, ${ }^{23}$ which in this case tends to locate the source of the crisis in the body of the individual migrant, seeing the person as bringing the Europe-threatening 'crisis' with them wherever they go. ${ }^{24}$ Such discourse suggests both that the roots of the crisis are elsewhere (in the countries of origin of the migrants) and that Europe is a 'victim' of this problematic movement of people. ${ }^{25}$

In their cross-European media analysis on the 'refugee crisis' (written for the Council of Europe), Georgiou and Zaborowski (2017) conclude that whereas the crisis was covered with significant diversity, the tendency to label refugees as outsiders and different 'others' dominated, leaving limited space for the refugees' own life stories, knowledge, voice, and agendas, both in media coverage and in European policymaking. ${ }^{26}$

The narrative of refugees as the source and rationale behind the 'crisis' in Europe simply allows for a comprehensive ignorance of the agenda of the refugees themselves. As Rajaram (2015) observes, depicting something as a 'crisis' is always based on fear, suggesting that it then becomes about the states' urgent capacity to react. Mobility and migration are two sides of the same coin, but only the latter is seen as a possible crisis. ${ }^{27}$ It seems that in positioning the migrating refugee as the source of crisis, the refugee becomes an 'element' of a faceless (and voiceless) collective, where no individual agency is separated and thus heard. 


\section{Refugees as unknown unknowns that need to be managed ${ }^{28}$}

'Wave', 'influx', and 'swarm' are just some of the words that have been used in the European political and media discourse about the mass movement of people. For example, the former prime minister of the United Kingdom, David Cameron, was criticised for his language about migrants when he spoke of a 'swarm'. ${ }^{29}$ In the second dominant narrative, metaphors taken from the natural world construct a view of the movement of refugees as something massive, uncontrollable, and intimidating. In essence, this rhetoric places refugees outside of politics, locating them merely as targets for management, intervention, and control. ${ }^{30}$ The emphasis being put on 'crisis' and urgent problems has paved the way for the European Union and its member states to change policies very quickly - and without full involvement of the European civil society. One key feature was the prominence of rush and urgency, underlining that there was simply no time for legal changes. Instead, Europeans were made to accept that policies can be altered without legal changes. ${ }^{31}$

The main discussions in the EU concern the distribution of responsibility for processing migrants and asylum seekers who enter or are already in EU territory. Whereas some countries refuse to take any, others complain about the disproportionate burden that they are facing. Still, the focus remains on keeping migrants and asylum seekers out of the EU. According to Human Rights Watch (2019), this includes problematic proposals for offshore processing and migration cooperation with non-EU countries with fewer resources, uneven human rights records, and less capacity to process asylum claims. ${ }^{32}$

One example of changing EU policies without a legal basis was the decision to expand the role of FRONTEX, the EU agency coordinating naval and military operations. FRONTEX became the 'European Border and Coast Guard Agency' in 2016; simultaneously its budget was tripled. ${ }^{33}$ The EU Commission made it overly clear that one key component of the European Union's migration agenda was to fight crime and effectively remove those who have no right to asylum in the EU. At the same time as the EU has been shaken by the deaths of people fleeing over the Mediterranean, FRONTEX has been involved in unlawful operations aimed at stopping migrants from entering the EU via Greek waters. ${ }^{34}$ As early as 2015, the European Commission also presented its new 'hotspot approach', which has involved creating large camps in Greece and Italy with the aim of 'helping' these countries to deal with the large number of new migrants. ${ }^{35}$ These large camps are responsible for coordinating the reception, registration, identification, and fingerprinting of asylum seekers and migrants. ${ }^{36}$ According to a study by the Danish Refugee Council in 2017, the migrants forced to stay at the hotspots face unsustainable living conditions and serious human rights violations (see also Hassouneh \& Pascucci in this book). The third example is the agreement on the EU-Turkey deal in 2016, which states that all new irregular migrants from Turkey to the Greek islands will be returned to Turkey. ${ }^{37}$ This deal is an example of the EU's management of asylum seekers as a problem that can be re-delegated outside EU's borders to undemocratic countries such as Turkey or Libya. One unfortunate example of 
this line of policymaking in the EU is the New Pact on Migration and Asylum, which was adopted in September 2020. It focuses on enhancing border procedures and underlines the solidarity in-between member states without any attention to the solidarity towards the asylum seekers and migrants.

Noteworthy in all these cases is how the 'crisis talk' affected the EU institutions' decisions: the justification behind the adopted novel controlling measures was not statutory, but political. Hafelach and Kurban point out that these decisions should have been based on the values and principles of the 1951 UN Refugee Convention. ${ }^{38}$ Also, the EU used the Dublin Regulation, which is a system of allocating responsibilities to examine asylum applications, not for protecting the refugees but for safeguarding the national security interests of the member states.

Some EU-level initiatives have striven to highlight the opportunities of migration and migrant knowledge. In June 2016, the European Commission launched a database called the Knowledge Centre for Migration and Demography (KCMD). As the name indicates, its task is to provide the EU's policymakers and decision-makers with relevant knowledge and evidencebased analyses in order to strengthen the response to the challenges posed by migration and leverage its opportunities and benefits. ${ }^{39}$ The KCMD data tools provide EU policymakers with instruments to access information and data about migration: the KCMD Migration Data Catalogue and the KCMD Dynamic Data Hub. However, in none of the databases can one find information on the knowledge and know-how of the refugees themselves in Europe. ${ }^{40}$

Instead, there is plenty of demographic and geographical data about immigration across the $27 \mathrm{EU}$ member states that support management of what is considered the problem: the unknown refugee. It is as if there is a fundamental gap between refugee knowledge and knowledge of refugees. The arm that is producing information about refugees for authorities and other decisionmakers is distinctly separate from the one that could contribute knowledge brought with the refugees. Though the aim of such knowledge-production may be well-meaning, in the process it risks rendering refugee knowledge invalid and irrelevant. The European Union is careful with the language it uses when writing about management of refugees. It avoids any wording that would infringe on human rights, while at the same time it bases its most significant measures on the control and management of refugees.

\section{Refugees as vulnerable people that need protection and help}

The third dominant narrative is that of the refugees being weak, vulnerable, and thus in need of protection, care, and aid. In particular, European media discourses on migration are loaded with colonial stereotypes, such as representations of migrants as 'victims' in need of protection (see Rajaram in this book). Promising relief and benevolence to the migrant in need, the representation is still harmful as it deprives the person of any kind of agency and sees them as a victim of circumstances, unable to do anything about their situation..$^{41}$ This representation is often combined with colonial stereotypes about 
physically looking non-European. ${ }^{42}$ According to Christiane Fröhlich, the 'migrant as victim' and the 'migrant as threat' tropes 'both perpetuate colonial power relations between seemingly stable, neutral, European identities and systems and threatening and/or damaged migrants standing outside of those spaces' ${ }^{43}$ Saara Pellander and Noora Kotilainen ${ }^{44}$ give an example of the reactions of the general public when encountering pictures of refugees that do not fit the representation of refugees as vulnerable victims. They note that refugee men with smartphones are perceived as 'too similar to us', and therefore they are at risk of not being seen as worthy of protection. ${ }^{45}$

Media stories and representations play into the dominant narrative of the vulnerable migrant, but the issue of vulnerability is also operationalised in public policy and public opinion. ${ }^{46}$ It is certainly true that migrants have experienced vulnerability, such as perilous sea journeys and harsh living conditions in camps, but the governing of migration can also produce various types of vulnerabilities. The dominant narrative of 'the vulnerable' may be damaging to the migrants categorised as such: it strips them of agency and subjectivity, and, in addition, these categorisations often rely on external evaluation about a migrant's situation. ${ }^{47}$ Some individuals are seen as vulnerable and worthy of protection, whereas others are regarded as not vulnerable enough. As Smith and Waite observe, 'Typically projected on to those deemed in need, the narratives regarding vulnerability saturate political narratives and many acts of solidarity towards refugees. As such, narratives may allow for "the vulnerable" to be alternately pitied and some of "them" "saved", whilst those refugees who are not deemed vulnerable may be expelled and excluded. ${ }^{48}$

The vulnerable victim narrative is also often feminised, being more strongly associated with migrant women and children, whereas men are seen in different social roles. ${ }^{49}$ Assumptions about gender are at the heart of how distinctions of vulnerability are made. Women and children are more easily read as innocent, at the mercy of others. Men, on the other hand, are depicted as actors of consequence, soldiers, and even violent perpetrators. ${ }^{50}$ The narrative of refugees as vulnerable victims and in need of measures being taken on behalf of them once again places the refugees outside of any agency and politics by pointing out their lack of self-sufficiency and control. There is no space for recognition of the knowledgeable person in this narrative.

\section{Refugees as dangerous others}

In their analysis of the European media landscape, Georgiou and Zaborowski (2017) proposed that migrants can occupy two different, either-or roles: they are either 'vulnerable outsiders' or 'dangerous outsiders'. ${ }^{51}$ The 'vulnerable refugee' metaphor stands in contrast with the fourth dominant narrative the migrant as a 'threat' - which links to the topic of securitisation. Securitisation frames migration as a challenge to national security and stability. Asylum seekers are socially and politically constructed as a security question, being feared to endanger internal security, cultural identity, and the welfare state. ${ }^{52}$ Migrants face securitised conditions at several stages of their 
journey: they might be fleeing from unstable conditions, on their route they face securitised borders designed to restrict and control their movement, and, finally, in their destination countries they may encounter a hostile environment, detention, and deportation. ${ }^{53}$ The linkage of terrorism with asylum seekers and refugees has further fuelled the public view of terrorist others. ${ }^{54}$

In September 2019, the president-to-be of the European Commission, Ursula von der Leyen, announced the nominees for the new European Commission. Among those was a portfolio named 'Vice-president for protecting our European way of life', which immediately sparked critical reactions even within the EU institutions. Pascucci and Kmak remark that the portfolio refers to values such as dignity, equality, and solidarity, yet at the same time 'illegal' migration is presented as a threat to the economy, security, and the self-defined values and identity of the EU. ${ }^{55}$ Framing migrants as a threat on the EU level thus strengthens the separation between those who are EU citizens and those who migrate or flee to the EU from elsewhere. ${ }^{56}$ Later, the title was changed to 'Promoting our European way of life', but the case still remains as an example of the threat narrative permeating the EU. During the Finnish EU presidency, a debate about the future of the EU's migration and asylum policy was initiated in the meetings of the Strategic Committee for Immigration, Frontiers and Asylum (SCIFA) and the Justice and Home Affairs. The meetings concluded that while the EU must show global leadership by providing international protection to those in need, ensuring effective control of its external borders must not be compromised. They made an explicit link, once again, between 'safe and orderly migration' and an increased sense of security among all residents. ${ }^{57}$

A survey by the Pew Research Center (2016) illustrates that the 'refugee crisis' and the threat of terrorism are very much related to one another in the minds of many Europeans. In eight of the ten European nations surveyed, half or more believed that incoming refugees increase the likelihood of terrorism in their country, whereas research evidence clearly points towards the opposite. ${ }^{58}$ The linkage between refugees and increased security problems is a strong narrative. This is visible even in the EU Commission's Agenda for Migration, which shows that the EU aims to continue its security-oriented strategy in migration management. ${ }^{59}$ The EU has continually associated migration with terrorism. There are two aspects to the EU migration policy, the 'Europeanisation' of internal policy, meaning free movement inside of the European Union member states, and the 'externalisation' of security threats, which has led to large camps just outside of the EU. The security discourse emphasises the need to further strengthen the EU's external borders. At the same time, the asylum policies are left to the discretion of the member states. The Malta Declaration of the EU in 2017 is a strong document of the fact that the EU has embraced the securitisation discourse officially and is ready to sacrifice its own values and externalise asylum outside its borders. SOS MEDITERRANEE, a humanitarian organisation working in the Mediterranean Sea, concluded: 'With the Malta Declaration, the European Union has laid the foundation for a massive breach of international law, financed by European taxpayers' money. ${ }^{\prime} 0$ 
The discourse that posits refugees as a security threat and a potential source of instability and insecurity for the EU and its citizens gives no voice to the refugees. The loud call for preventing terrorism effectively silences refugee knowledge, contributing to ignorance of their agency and capability.

\section{Refugees as potential saviours of Europe}

In the fifth dominant narrative, refugees are seen as potential saviours of Europe, providing cheap labour and correcting the demographic imbalance of the continent's ageing population. According to the cross-European media analysis by Georgiou and Zaborowski, it is striking how the press has reported on migrants and refugees as a monolithic, unskilled group. In the case that any distinction was made, it was the country of origin that was mentioned $(62 \%)$. Only $7 \%$ of the media mentioned the profession of the refugees. ${ }^{61}$ Thus, the media presents a picture of refugees as un-educated and unskilled, which then supports the idea that refugees are suitable for low-paid and physically demanding jobs.

Turning seekers of help into productive citizens is high on the agenda of most of the member states - and consequently also the European Commission. It is seen as evident that Europe is competing with other economies to attract a skilled labour force. ${ }^{62}$ Changes in the skills required by the EU between 2012 and 2025 are expected to show a sharp increase (+23\%) in the share of jobs employing higher-educated labour. ${ }^{63}$ There are already shortages in key sectors, such as science, technology, engineering, and healthcare. The European Union makes it apparent in its statements that there is a clear need to build up Europe's own skill base and equip people for inclusion in today's labour markets.

For this purpose, the EU Skills Profile Tool for third-country nationals was launched in 2017. It is meant to support organisations that are working with refugees and new migrants to establish their previous education, training, and experience. It is part of the general New Skills Agenda for Europe, which strives for better matches of training and employment in the EU. Though its focus is strictly employment-oriented, it at least seems to try to incorporate the knowledge of the refugees into the integration programmes. According to this Agenda, approximately $25 \%$ of non-EU nationals are highly skilled. However, two-thirds of them are inactive in the labour market, unemployed, or over-qualified for their jobs. ${ }^{64}$ Similarly to the EU's New Skills Agenda, in 2017 the Council of Europe launched a project that aims to create a permanent structure in the field of recognition of refugee qualifications. The project is called the European Qualifications Passport for Refugees, and it aims to provide an assessment tool of the higher education qualifications of refugees, in order to turn these into a competitive and certified curriculum vitae. ${ }^{65}$ The focus on finding a labour force among newcomers omits the structural discrimination and racism-related difficulties of refugees in finding work. ${ }^{66}$

A study by Matti Sarvimäki (2017) on the labour market performance of earlier immigrants living in Finland showed that immigrants born in Afghanistan, 
Iraq, and Somalia had substantially lower employment rates, earned less, and received more social benefits than other immigrant groups or natives in 19902013. The immigrant-native gaps in employment and earnings remained large even after ten years' time. ${ }^{67}$ The reasons are linked to not recognising the skills of refugees and to high levels of labour-market racism in Finland. ${ }^{68}$

The following citation describes well how the EU on one hand offers protection for the refugee and on the other hand sees the refugee as someone who should contribute to the European economy: 'The EU must continue to offer protection to those in need. It must also recognise that the skills needed for a vibrant economy cannot always immediately be found inside the EU labour market or will take time to develop. ${ }^{69}$ What constitutes the needed skills seems to be predefined, and newcomers should be able to demonstrate these skills in order to foster the European economy. The definition of skills in these documents follow traditions of science and politics that have long instrumentalised precarity to the service of the markets.

The European Union is facing a significant demographic problem: as the population is aging, the number of working-age people is estimated to decline by 17.5 million during the next decade. ${ }^{70}$ Countries are concerned about the age-dependency ratio and politicians are urgently calling on academia and labour unions to come up with long-term solutions to secure future pensions and benefits. According to Eurostat (2020), the EU 27 currently has a ratio of $32,{ }^{71}$ but in 2050 - if no drastic demographic change occurs - the ratio will be 47. In many countries, such as in Finland, the situation is even worse, as it is one of the most rapidly aging countries in Europe. ${ }^{72}$

In this case, the EU sees migration as the only possible solution to the problem. To quote the European Agenda on Migration: 'Migration will increasingly be an important way to enhance the sustainability of our welfare system and to ensure sustainable growth of the EU economy. ${ }^{173}$ As Peo Hansen writes, it would seem reasonable to expect that the refugees are greeted as a first, though modest step towards reducing the EU's age-dependency ratio. ${ }^{74} \mathrm{He}$ concludes that, contrary to what would make sense in this situation, the EU Commission has 'spent all its energies on devising new measures to prevent refugees from entering the EU' ${ }^{75}$ It seems like the European Union does not want asylum seekers with rights but instead it prefers migration in a circular austere commodity form: the new working force should have no rights to citizenship or long-term perspectives of staying.

\section{Search for refugee knowledge in the dominant European narrative}

Migration consists today of 'an increased number of new, small and scattered, multiple-origin, transnationally connected, socio-economically differentiated and legally stratified ${ }^{376}$ migrants. The groups are as diverse as humankind can be. Vertovec has aptly called the current situation 'super-diversity', with the aim of highlighting the ontologically different situations that people who cross borders are in. Refugees are fundamentally different from other migrants because they are fleeing-and seeking a place of security. The European Union has created a strong 
image of itself as the ideal destination for refugees, which it emphasises in its official statements. This self-image of Europe is illustrated, for example, in the following statement: 'Europe, due to its geographic position and its reputation as an example of stability, generosity and openness against a background of growing international and internal conflicts, climate change and global poverty, is likely to continue to represent an ideal refuge for asylum seekers and migrants. ${ }^{77}$ But just how ideal is Europe for asylum seekers when we read in newspapers about the unbearable conditions in the refugee camps, detention facilities, and desperate attempts by many to reunite with their families? We may wonder whether there is any space for humanitarian politics in the field of refugees' migration to Europe.

The question of 'who is missing in these narratives?' must be answered that the Europe-focused, Euro-centric narrative has overridden the experiences of the refugees themselves. As Bourdieu put it, "The weapons of the weak are always weak weapons." 78 The refugees themselves have very restricted possibilities to change the course of their representation. 'It is this movement [of migrants] that most effectively challenges the renationalisation of politics and the fragmentation of European space', write Manuela Bojadžijev and Sandro Mezzadra. ${ }^{79}$ In many ways, it seems apparent that recognising refugee knowledge is inherently difficult because of all the dominant discourses that are guiding our gaze away from it. Seeing refugees as vulnerable, as potential threats, and in all the other 'convenient' roles that we assign to them hinders us from seeing them as persons with capabilities.

The combination of all the narratives regarding refugees mentioned in this chapter diminishes the chances of seeing refugees as people with multifaceted skills and perspectives that would be useful for their destination country or for Europe as a whole. It is the European agenda, what Europe thinks it wants and needs, that guides the ideas about belonging. According to Benhabib, 'The struggle over what gets included in the public agenda is itself a struggle for justice and freedom. ${ }^{80}$ The question is then, where and how could those with limited access to power start changing the dominant agendas?

The dominant narratives regarding refugees discussed in this chapter form discourses to be further analysed. It is important to note that discourses transmit and produce power. A discourse may reinforce those in power, but it also 'undermines and exposes power, renders it fragile and makes it possible to thwart'.$^{81}$ That is to say, none of these narratives are the truth, and not even the partial truth, but merely pictures or stereotypes that we employ when facing uncertain futures. Refugee knowledges cannot be subsumed under the idea of high-skilled or low-skilled labour according to the European standards. There is much more multifaceted potential in the concept of refugee knowledges, as becomes apparent in this volume.

\section{Acknowledgments}

This work has been made possible by the Academy of Finland funded Centre of Excellence in Law, Identity and the European Narratives, funding decision numbers 312431 and 336678. 


\section{Bea Bergholm and Reetta Toivanen}

\section{Notes}

1 Kakissis, 2018, 25-37.

2 See e.g. Crawley and Skleparis, 2018, 48-64; Holmes and Castaneda, 2016, 12-24.

3 See e.g. Kallius, Monterescu, and Rajaram, 2016, 25-37.

4 Andersson, 2016, 1055-1075.

5 See Tazzioli and De Genova, 2016; Davitti and Chimia, 2017, 1-46.

6 Jacobs, 2019.

7 Kuhn and Jackson, 2008, 474.

8 See e.g. Knuuti, 2020.

9 Malkki, 1996, 377-404.

10 In 2019, the European Commission declared the 'refugee crisis' to be over.

11 Bourdieu and Wacquant, 1999, 41-58.

12 Fraser, 1992.

13 Benhabib, 2002, 106; see also Hassouneh and Pascucci's chapter in this volume.

14 Koselleck, 2002, 237.

15 Edelman, 1977.

16 Jeandesboz and Pallister-Wilkins, 2014, 116.

17 Bourdieu, 1992, 139.

18 Rajaram, 2015, 25-37.

19 For example, the media outlet Al Jazeera made a strong point of calling the situation a 'refugee crisis' instead of a 'migration crisis', for the sake of emphasis and, as they said, due to the need to use factual words (Malone, 2015). Inspired by that, 72,000 people signed a change.org petition to ask $\mathrm{BBC}$ to change its language accordingly.

20 Tazzioli and De Genova, 2016.

21 Tazzioli and De Genova, 2016, 20.

22 Tazzioli and De Genova, 2016, 11.

23 Bourdieu, 1989, 21.

24 Tazzioli and De Genova, 2016, 20.

25 Tazzioli and De Genova, 2016, 12.

26 Georgiou and Zaborowski, 2017.

27 Rajaram, 2015.

28 David Chandler's formulation originally addressed such crucial knowledge gaps that are hidden, underlying processes of determination, which we know that we do not fully know of (Chandler, 2014, 50). The refugees are described as such unknown matter that needs to be managed - even when we know that we do not fully know them.

29 BBC News, 2015.

30 See Foucault, 1991.

31 For the case of Finnish Migri decisions, see Saarikkomäki et al., 2018. Migri is the Finnish Migration Service, which makes decisions on asylum and residence permits.

32 Human Rights Watch, 2019.

33 The European Parliament, 2016.

34 Waters, Freudenthal, and Williams, 2020.

35 European Commission, 2015, 6.

36 European Commission, 2015.

37 European Council, 2016.

38 Haferlach and Kurban, 2017, 86.

39 European Commission, n.d.-b. Knowledge Centre on Migration and Democracy.

40 European Commission, n.d.-b. Knowledge Centre on Migration and Democracy. 
41 Benhabib, 2002; Ferrarese, 2018.

42 Fröhlich, 2017, 5-11.

43 Fröhlich, 2017, 8.

44 Pellander and Kotilainen, 2017.

45 See also Malkki, 1996, 377-404.

46 Smith and Waite, 2019, 2289-2307.

47 Ferrarese, 2018.

48 Smith and Waite, 2019, 2295.

49 Helms, 2015; see also Malkki, 1996, 377-404.

50 Helms, 2015.

51 Georgiou and Zaborowski, 2017, 3.

52 Huysmans, 2000, 751-777.

53 Mixed Migration Centre, 2019.

54 Toivanen, 2010, 282.

55 Pascucci and Kmak, 2019.

56 Pascucci and Kmak, 2019.

57 Council of the European Union, 2019.

58 Wike, Stokes, and Simmons, 2016.

59 See Haferlach and Kurban, 2017, 86.

60 SOS MEDITERRANEE, 2020.

61 Georgiou and Zaborowski, 2017, 10.

62 European Commission, 2015.

63 Descy, 2014.

64 European Commission, n.d.-a "European Skills Agenda Website."

65 Council of Europe, 2020.

66 On migrants in Finland, see e.g. Krivonos, 2019; Ahmad, 2020, 826-843.

67 Sarvimäki, 2017.

68 See Akhlaq Ahmad's field research 2020.

69 European Commission, 2015, 7.

70 Eurostat, 2020.

71 This indicator is the ratio between the projected number of persons aged 65 and over (the age when they are generally economically inactive) and the projected number of persons aged between 15 and 64. The value is expressed per 100 persons of working age (15-64).

72 Eurostat, 2020.

73 European Commission, 2015.

74 Hansen, 2018, 128.

75 Hansen, 2018, 130.

76 Vertovec, 2007, 1024.

77 Apap, Radjenovic and Dobreva, 2018.

78 Bourdieu, 2001, 32.

79 Bojadžijev and Mezzandra, 2015.

80 Benhabib, 2002, 92.

81 Foucault, 1998, 100-101.

\section{References}

Ahmad, Akhlaq. 2020. "Do Equal Qualifications Yield Equal Rewards for Immigrants in the Labour Market?" Work, Employment and Society 34, no. 5: 826-843. doi:10.1177/0950017020919670. 
Andersson, Ruben. 2016. "Europe's Failed 'Fight' Against Irregular Migration: Ethnographic Notes on a Counterproductive Industry." Journal of Ethnic and Migration Studies 42, no. 7: 1055-1075. doi:10.1080/1369183X.2016.1139446.

Apap, Joanna, Anja Radjenovic, and Alina Dobreva. 2018. The Migration Issue. European Parliamentary Research Service. PE 635.542. https://www.europarl. europa.eu/RegData/etudes/BRIE/2019/635542/EPRS_BRI(2019)635542_EN.pdf.

BBC News. 2015. "David Cameron Criticised over Migrant 'Swarm' Language." Accessed July 30, 2015. https://www.bbc.com/news/uk-politics-33716501.

Benhabib, Seyla. 2002. The Claims of Culture - Equality and Diversity in the Global Era. Princeton: Princeton University Press. doi:10.2307/j.ctv346pnd.

Bojadžijev, Manuela, and Sandro Mezzandra. 2015. "'Refugee Crisis' or Crisis of European Migration Policies?” Focaal Blog, Accessed November 12, 2015. http:// www.focaalblog.com/2015/11/12/manuela-bojadzijev-and-sandro-mezzadra-refugeecrisis-or-crisis-of-european-migration-policies/.

Bourdieu, Pierre. 1989. "Social Space and Symbolic Power.” Sociological Theory 7, no. 1: 14-25.

Bourdieu, Pierre. 1992. An Invitation to Reflexive Sociology. Cambridge: Polity Press. Bourdieu, Pierre. 2001. Masculine Domination. Stanford: Stanford University Press. Bourdieu, Pierre, and Loïc Wacquant. 1999. "On the Cunning of Imperialist Reason.” Theory, Culture \& Society 16, no. 1: 41-58.

Chandler, David. 2014. "Beyond Neoliberalism: Resilience, the New Art of Governing Complexity.” Resilience 2, no. 1: 47-63. doi:10.1080/21693293.2013.878544.

Council of Europe. 2020. European Qualifications Passport for Refugees. https:// rm.coe.int/eqpr-leaflet-en-web-july-2020/16809ee917.

Council of the European Union. 2019. "Way Forward for EU Migration and Asylum Policy-outcome of Discussions." Presidency Report, Accessed November 22, 2019. https://data.consilium.europa.eu/doc/document/ST-14364-2019-INIT/en/pdf.

Crawley, Heaven, and Dimitris Skleparis. 2018. "Refugees, Migrants, Neither, Both: Categorical Fetishism and the Politics of Bounding in Europe's 'Migration Crisis'." Journal of Ethnic and Migration Studies 44, no. 1: 48-64. doi:10.1080/13691 83X.2017.1348224.

Danish Refugee Council. 2017. "Fundamental Rights and the EU Hotspot Approach." Accessed October, 2017. https://reliefweb.int/sites/reliefweb.int/files/resources/ Fundamental $\% 20$ rights_web $\% 20 \% 281 \% 29$.pdf.

Davitti, Daria, and Annamaria La Chimia. 2017. "A Lesser Evil? The European Agenda on Migration and the Use of Aid Funding for Migration Control." UCD Working Papers in Law, Criminology \& Socio-Legal Studies Research Paper, no. 7: 1-46. https://ssrn.com/abstract=2966042.

Descy, Pascaline. 2014. "Projected Labour Market Imbalances in Europe: Policy Challenges in Meeting the Europe 2020 Employment Targets." OECD/European Union: Matching Economic Migration with Labour Market Needs. doi:10.1787/9789264216501-12-en.

Edelman, Murray. 1977. Political Language: Words That Succeed and Policies That Fail. Chicago: University of Chicago Press.

European Commission. 2015. A European Agenda on Migration. https://ec.europa.eu/ home-affairs/sites/homeaffairs/files/what-we-do/policies/european-agenda-migration/background-information/docs/communication_on_the_european_agenda_ on_migration_en.pdf.

European Commission. n.d.-a "European Skills Agenda Website." European Commission, Accessed November 2, 2020. https://ec.europa.eu/social/main. jsp?catId=1223\&langId=en 
European Commission. n.d.-b Knowledge Centre on Migration and Democracy, Accessed October 28, 2020. https://ec.europa.eu/knowledge4policy/migration-demography_en.

European Council. 2016. EU-Turkey Statement. Press release, Accessed March 18, 2016. https://www.consilium.europa.eu/en/press/press-releases/2016/03/18/eu-turkey-statement

European Parliament. 2016. Regulation (EU) 2016/1624 of the European Parliament and of the Council, Accessed September 14, 2016. https://eur-lex.europa.eu/legalcontent/EN/TXT/HTML/?uri=CELEX:32016R1624\&from=EN.

EuroStat. 2020. Projected Old-age Dependency Ratio, Accessed April 30, 2020. https:// ec.europa.eu/eurostat/databrowser/view/tps00200/default/table?lang=en.

Ferrarese, Estelle. 2018. Vulnerability and Critical Theory. Translated by Steve Corcoran. Leiden: Brill.

Foucault, Michel. 1991. "Governmentality." In The Foucault Effect: Studies in Governmentality, edited by Graham Burchell, Colin Gordon, and Peter Miller, 87104. Chicago: The University of Chicago Press.

Foucault, Michel. 1998. The History of Sexuality: The will to Knowledge. London: Penguin. Fraser, Nancy. 1992. "Rethinking the Public Sphere: A Contribution to the Critique of Actually Existing Democracy." In Habermas and the Public Sphere, edited by Craig Calhoun, 109-142. Cambridge, MA: MIT Press.

Fröhlich, Christiane. 2017. "A Critical View on Human Mobility in Times of Crisis." Global Policy 8, no. 1: 5-11.

Georgiou, Myria, and Rafal Zaborowski. 2017. Media Coverage of the "Refugee Crisis": A cross-European Perspective. Council of Europe Report. DG1 (2017) 3.

Haferlach, Lisa, and Dilek Kurban. 2017. "Lessons Learnt from the EU-Turkey Refugee Agreement in Guiding EU Migration Partnerships with Origin and Transit Countries." Global Policy 8, no. 4: 85-93.

Hansen, Peo. 2018. "Asylum or Austerity? The 'Refugee Crisis' and the Keynesian Interlude." European Political Science 17, no. 1: 128-139.

Helms, Elissa. 2015. "Men at the Borders: Gender, Victimhood, and War in Europe's Refugee Crisis." Focaal Blog, Accessed December 22, 2015. http://www.focaalblog. com/2015/12/22/elissa-helms-men-at-the-borders-gender-victimhoodand-war-in-europes-refugee-crisis/.

Holmes, Seth M., and Heide Castaneda. 2016. "Representing the 'European Refugee Crisis' in Germany and Beyond: Deservingness and Difference, Life and Death." American Ethnologist 43, no. 1: 12-24. doi:10.1111/amet.12259.

Human Rights Watch. 2019. "The European Union - Events from Year 2018." Accessed October 28, 2020. https://www.hrw.org/world-report/2019/country-chapters/european-union\#fc635d.

Huysmans, Jef. 2000. "The European Union and the Securitization of Migration." Journal of Common Market Studies 38, no. 5: 751-777.

Jacobs, Joela. 2019. "Refuge and Refuse: Migrant Knowledge and Environmental Education in Germany." Migrant Knowledge, Accessed September 13, 2019. https:// migrantknowledge.org/2019/09/13/refuge-and-refuse-migrant-knowledgeand-environmental-education-in-germany/.

Jeandesboz, Julien, and Polly Pallister-Wilkins. 2014. "Crisis, Enforcement and Control at the EU Borders." In Crisis and Migration: Critical Perspectives, edited by Anna Lindley, 115-135. London: Routledge.

Kakissis, Joanna. 2018. "Europe Does Not See Us As Human: Stranded Refugees Struggle in Greece.” Parallels/NPR, March 9, 2018. https://www.npr.org/sections/ parallels/2018/03/09/589973165/europe-does-not-see-us-as-human-strandedrefugees-struggle-in-greece?t=1605614820094. 
Kallius, Annastiina, Daniel Monterescu, and Prem Kumar Rajaram. 2016. "Immobilizing Mobility: Border Ethnography, Illiberal Democracy, and the Politics of the "Refugee Crisis" in Hungary." American Ethnologist 43, no. 1: 25-37.

Knuuti, Karoliina. 2020. "Helsingin 'Kielitaidottomat' Kielinerot." Maailman Kuvalehti, Accessed April 17, 2020. https://www.maailmankuvalehti.fi/2020/2/pitkat/helsingin-kielitaidottomat-kielinerot.

Koselleck, Reinhart. 2002. The Practice of Conceptual History: Timing History, Spacing Concepts. Translated by Samuel Todd Presner. Stanford: Stanford University Press.

Krivonos, Daria. 2019. "Migrations on the Edge of Whiteness: Young Russianspeaking Migrants in Helsinki, Finland." PhD diss., University of Helsinki. https:// helda.helsinki.fi/handle/10138/304004.

Kuhn, Timothy, and Michele H. Jackson. 2008. "Accomplishing Knowledge: A Framework for Investigating Knowing in Organizations." Management Communication Quarterly 21, no. 4: 454 485.

Malkki, Liisa. 1996. "Speechless Emissaries: Refugees, Humanitarianism, and Dehistoricization." Cultural Anthropology 11, no. 3: 377-404.

Malone, Barry. 2015. "Why Al Jazeera will not say Mediterranean 'Migrants'." Al Jazeera, Accessed August 20, 2015. https://www.aljazeera.com/blogs/editorsblog/2015/08/al-jazeera-mediterranean-migrants-150820082226309.html.

Mixed Migration Centre. 2019. The Ever-Rising Securitisation of Mixed Migration. http://www.mixedmigration.org/articles/the-ever-rising-securitisationof-mixed-migration/.

Pascucci, Elisa, and Magdalena Kmak. 2019. "Eurooppalaisen Elämäntavan Suojeleminen.” Politiikasta.fi, Accessed November 7, 2019. https://politiikasta.fi/ eurooppalaisen-elamantavan-suojeleminen/.

Pellander, Saara, and Noora Kotilainen. 2017. "(Not) Looking Like a Refugee: Visual Memories of Refugeeness and the Figure of the "iPhone Man." Border Criminologies Blog, Accessed June 16, 2017. https://www.law.ox.ac.uk/research-subject-groups/ centre-criminology/centreborder-criminologies/blog/2017/06/not-looking.

Pew Research Center. July, 2016. "Europeans Fear Wave of Refugees Will Mean More Terrorism, Fewer Jobs."

Rajaram, Prem Kumar. 2015. "Beyond Crisis: Rethinking the Population Movements at Europe's Border." Focaal blog, Accessed October 19, 2015. last accessed April 28, 2020. http://www.focaalblog.com/2015/10/19/prem-kumar-rajaram-beyond-crisis.

Saarikkomäki, Elsa, Nea Oljakka, Johanna Vanto, Elina Pirjatanniemi, Juha Lavapuro, and Anne Alvesalo-Kuusi. 2018. Kansainvälistä Suojelua Koskevat Päätökset Maahanmuuttovirastossa 2015-2017. Pilottitutkimus 18-34-Vuotiaita Irakin Kansalaisia Koskevista Myönteisistä Ja Kielteisistä Päätöksistä. Turun Yliopisto: Oikeustieteellisen Tiedekunnan Tutkimusraportteja Ja Katsauksia 1.

Sarvimäki, Matti. 2017. Labor Market Integration of Refugees in Finland. VATT Institute for Economic Research: VATT Research Reports 185/2017.

Smith, Kate, and Louise Waite. 2019. "New and Enduring Narratives of Vulnerability: Rethinking Stories about the Figure of the Refugee." Journal of Ethnic and Migration Studies 45, no. 13: 2289-2307.

SOS MEDITERRANEE. 2020. Three Years Following the Malta Declaration - SOS MEDITERRANEE Denounces How the EU Support for the Libyan Coast Guard Further Worsened the Situation in the Central Mediterranean. Press release, Accessed January31,2020.https://sosmediterranee.com/press/three-years-following-the-maltadeclaration-sos-mediterranee-denounces-how-the-eu-support-for-the-libyancoast-guard-further-worsened-the-situation-in-the-central-mediterranean/. 
Tazzioli, Martina, and Nicholas De Genova. 2016. "Europe/Crisis: New Keywords of 'the Crisis' in and of 'Europe'." New Keywords Collective. Near Futures Online 1 "EuropeataCrossroads".http://nearfuturesonline.org/europecrisis-new-keywords-ofcrisis-in-and-of-europe/.

Toivanen, Reetta. 2010. "Counterterrorism and Expert Regimes: Some Human Rights Concerns.” Critical Studies on Terrorism 3, no. 2: 277-294.

Vertovec, Steven. 2007. "Super-diversity and its Implications." Ethnic and Racial Studies 30, no. 6: 1024-1054.

Waters, Nick, Emmanuel Freudenthal, and Logan Williams. 2020. "Frontex at Fault: European Border Force Complicit in 'Illegal' Pushbacks." Bellingcat, Accessed October 23, 2020. https://www.bellingcat.com/news/2020/10/23/frontex-at-faulteuropean-border-force-complicit-in-illegal-pushbacks/.

Wike, Richard, Bruce Stokes, and Katie Simmons. 2016. "Europeans Fear Wave of Refugees Will Mean More Terrorism, Fewer Jobs." Pew Research Center, Accessed July 11,2016. https://www.pewresearch.org/global/2016/07/11/europeans-fear-waveof-refugees-will-mean-more-terrorism-fewer-jobs/. 


\title{
4 The world as an exiling political structure
}

\section{Yassin al-Haj Saleh's conceptualisation of exile}

\author{
ElSayed Mahmoud ElSehamy
}

\section{Introduction: an overview on al-Haj Saleh}

This chapter describes Yassin al-Haj Saleh's conceptualisation of exile. Al-Haj Saleh is a widely known Syrian writer and scholar who participated in the 2011 Syrian revolution from the early beginnings and started writing about the emerging events that accompanied the popular uprising. I provide a brief biographical overview on his life before showing how he operationalises exile analytically as practices of exclusion and marginalisation, what he calls 'exilement'. Throughout the chapter, I construct a narrative from a selection of his work, which was published in Arabic mostly after the Syrian revolution in 2011. Putting fragments together, I illustrate my understanding of his views of exile as an act of negation of history through political eternity, freedom through political imprisonment, and home through exile and displacement by the exiling authority. Adding to this, I elaborate on al-Haj Saleh's understanding of exile as exemplified by some predominant practices of exclusion in Syria, such as oblivion, rape and enforced disappearances which also conspire to negate Syrians' political rights. Building on that, I illustrate how he contends the negation of these negations through the processes of 'enjailment' 1 and 'exilification' as attempts at 'exiling exile'. I show how he differentiates between being a refugee and being an exile, and how exile is a liminal, (in)dependent experience that is everywhere and nowhere at once. I conclude by showing how he argues for the end of exile, by illustrating how the world became an exile from one side and how exile is a contemporary global phenomenon from the other.

In his early youth, al-Haj Saleh was a member of the Syrian Communist Party. Al-Haj Saleh was among many who were arrested in the 1980s because of their political activism against Hafez al-Assad's regime. He spent 16 years in Aleppo Central Prison, Adra Prison and the notorious Tadmor prison, between 1980 and 1996. As "a child of the prison," his experience of imprisonment represents a significant formation of his political thought. ${ }^{3} \mathrm{He}$ learned English in prison. Upon his release, he was never allowed a passport. He started to work on political journalism and translation, playing an active role in redefining the role of the "public intellectual' through his works. ${ }^{4}$ Al-Haj Saleh's personal life is part of the Syrian tragedy and his writing is a by-product of a constant mediation between the analytical, the observatory

DOI: $10.4324 / 9781003092421-6$ 
and the participatory. ${ }^{5}$ When the Syrian revolution broke out in March 2011, he was in Damascus. To avoid police arrest and self-censorship while writing about the revolution, he lived in hiding for two years. ${ }^{6}$ In 2013 , he was smuggled from Damascus into Ghouta through a network of tunnels, passing by his native city of al-Raqquah and ending up in Turkey. The film Our Terrible Country (Baladna al-Rahib) shows part of his life in hiding and his journey throughout the 'liberated' zones of Damascus. Upon arrival in his native al-Raqquah, as the epic film shows, al-Haj Saleh finds that The Islamic State of Iraq and the Levant (ISIS) had taken the city as its capital, which led him to continue hiding until he reached Turkey. During his journey, he kept contact with his wife, Samira al-Khalil, a former political prisoner of the regime of Hafez al-Assad and a political activist. On the way to Turkey, he learned that his brother, Firas, had been abducted by ISIS. In December 2013, upon his arrival in Turkey, Samira al-Khalil was abducted along with her fellow prominent activists Razan Zeitouneh, Wael Hamadeh, and Nazem Hamadeh, in the besieged city of Douma, by an Islamist militant group. Their whereabouts are still unknown. ${ }^{7}$ Al-Haj Saleh was a refugee in Turkey from 2013 to 2017 and is now a political exile in Berlin.

Exile is not a main theme in al-Haj Saleh's works. His writings on exile are fragmented and scattered throughout many of his essays, which were published mostly in Arabic. Additionally, his work on exile is not widely known beyond the Arab world. Being the first account that taps into this subject thoroughly in the light of post-2010 Arab revolutions, drawing scholarly attention to his work is also important because it is an emerging account that aims to articulate the phenomenon of exile beyond its personified, literary and/or figurative aesthetics. ${ }^{8}$ Al-Haj Saleh's work develops analytical tools for studying exile as "a political institution of dictatorship". ${ }^{9}$ In the way he conceptualises exile, as I show, lies a story about Syrian social formation. His emergent account of exile is evidence of how practices and knowledge are formed through experiences of imprisonment, forced disappearance, displacement, refuge, and exile. His account goes beyond methodological nationalism and theoretical Eurocentrism by employing a non-state-centred perspective of conceptualising exile, which challenges the primacy of static forms of political membership. He reflects on his exile as a condition of political and cultural significance, showing that exile is a site of personal growth and a source of political awareness that enables understating the complexities of the social.

Al-Haj Saleh is often referenced for his political analysis and intellectual trajectory. He has been expressing the hopes and the challenges of the revolution. He is widely considered the "conscience of the Syrian revolution" and the "sage of the Syrian revolution" (hakim al-thawra), due to his explicit analysis and critique of power relations under the Assad regime, sectarianism, and political Islam. Massouh ${ }^{10}$ provides an overview of al-Haj Saleh's life and scholarly productions about Syria, situating his intellectual contributions in wider themes in contemporary Arab thought. He argues that al-Haj Saleh upholds a humanistic, ideal way of critique as a form of agency and social responsibility. Al-Haj Saleh seeks to denaturalise assumptions about 


\section{2}

ElSayed Mahmoud ElSehamy

authoritarianism and sectarianism in contemporary Syria throughout his cultural, discursive productions, "in an effort to expand the parameters of both what is imaginable and what is doable". ${ }^{11}$ While Massouh tackled alHaj Saleh's scholarly productions and public activities in exile, he did not demonstrate al-Haj Saleh's understanding of exile. Haugbolle (2015) analyses the film Our Terrible Country to discuss debates about revolution, exile and representations in Syria and the Middle East. He interrogates the role of intellectuals as 'revolutionary icons', and their work in the path of revolutions and counter-revolutions, depicting al-Haj Saleh's role in the Syrian Revolution. Al-Haj Saleh represents an intellectual leadership that is inspired by his life history and his scholarly productions, inspiring "collective action and reflection that is meant to transform the social imaginary and prepare the social conditions conducive for revolution". ${ }^{12}$ While Haugbolle argues that exile produces self-critique, he tapped into how exile and defeat influenced al-Haj Saleh to produce radical critiques of the Syrian state, Islamism and modernity. Yet, how al-Haj Saleh understands exile is still missing in the academic literature. (Figure 4.1).

\section{Al-Haj Saleh's use of exile: exilement as practices of exclusion}

For al-Haj Saleh, we cannot only look where the exiled is, but from where and how they come to be as such. In Arabic, the word 'exile' (al-manfa) is the gerund of the verb 'to negate something'. Based on this linguistic conceptualisation of the word, al-Haj Saleh tends to use 'exile' for any action negating another with relations of dispossession, disenfranchisement and marginalisation. Thus, in his view, 'to negate' is synonymous with 'to exile'. He locates 'exile' within an

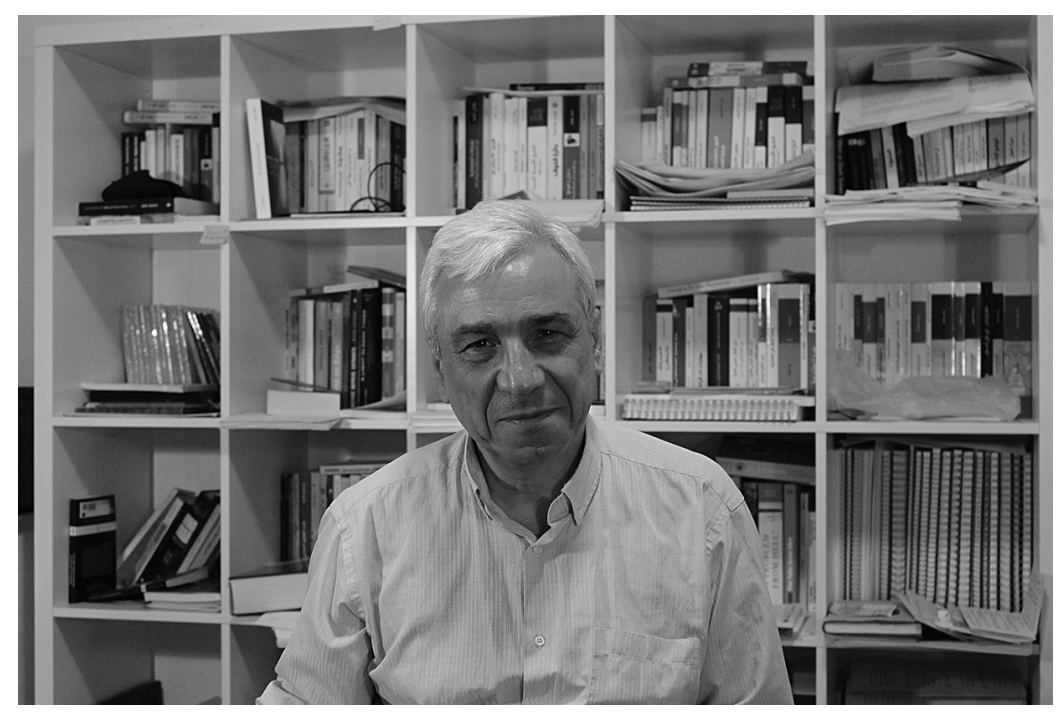

Figure 4.1 Yassin al-Haj Saleh. Image by Yassin Swehat, February 2021. 
analytical (exiling) complex, in which an exiling authority is embedded in an exiling political structure, which exiles individuals through the processes and practices of exilement. ${ }^{13}$ Exilement is the practices and forces that lead to the production of individual exiles. These processes of exilement, violent in their nature, give analytical views on the social structure of the Syrian revolution. ${ }^{14}$ Hence, for al-Haj Saleh, exile adopts multiple manifestations. To exile an individual or a population would mean to deprive them of their rights. In that perspective, al-Haj Saleh does not reduce 'exile' to losing the homeland and being a refugee. Erasure of a person's points of reference is a form of exile, being black in a white-dominated society is being an exile, being forced to do compulsory conscription is exile of an individual's freedom, and writing about exile is one way of exiling that exile.

Exiling exile refer to the attempts to negate what exilement aims to negate. It is a negation of negation. If death, in necropolitics, is a space where freedom and negation operate, ${ }^{15}$ exile is a space in which the negation of freedom and the negation of that negation interact. As losing one's homeland, for example, is an effect of exile, the negation of exile requires a recreation of what might be a 'home' otherwise. Al-Haj Saleh expands the understanding of exile to analyse it in structural terms. As he does not separate the phenomenon of exile from the political situation from which it emerges, he puts it in association with other phenomena that are common in that context. He juxtaposes the experience of exile with experiences of political imprisonment, forced disappearance, rape, and oblivion (al-mansa). These phenomena are inseparable. They are generative, procreative and bleed into each other. In the following paragraphs, I illustrate the way in which al-Haj Saleh characterises these phenomena as forms of exilement.

\section{Political eternity as an exile: exiling history through 'political' eternity}

Political eternity is the planned duration of the Assad regime's rule in Syria and the intention of staying in power forever, through sectarianism, dynasty and inheritance. Al-Haj Saleh builds his understanding of eternity on Snyder's 'politics of eternity' 16 to indicate that eternity means ensuring the eternal rule of the Assad dynasty over Syria. ${ }^{17}$ Starting from 1980, slogans such as 'Assad or we burn the country,' 'Assad or nobody,' 'Assad or to hell with the country' and 'Hafez Assad, forever' became dominant in Syria. ${ }^{18}$ Such slogans were the daily practices of the regime, aspiring to instil its dynasty in rule forever through sectarianism and racism. ${ }^{19}$ Analysing state formation under the Assad regime from the 1980s, al-Haj Saleh argues that the Assadist state is not only a dictatorship, but a dictatorship with genocidal tendencies. $^{20}$ The violent suppression of peaceful mass protests that broke out across Syria in 2011 and the militarisation of the revolution was a product of a genocidal state which itself is an accumulation of a long history of domination, humiliation, and sectarianism.

For al-Haj Saleh, the etymological relations in Arabic between eternity ( $a b a d)$ and genocide (ibada) is not a coincidence. The Assadist regime's plans 
for eternity were "intimately bound up with massacres and extermination... and broadening of killing for the purpose of securing power over time, and of preventing change". ${ }^{21}$ Eternity, then, is a form of preventing the future from coming by fixating the present and exterminating whoever seeks change, whether individuals, movements or institutions. It is a war against the future. From launching wars and wholesale massacres, the regime takes its main policy, namely "to exterminate opponents politically and morally by denying that they have a public cause; to exterminate them physically by declaring that their annihilation is required". ${ }^{22}$ The violence of the Assad regime is structural, a first choice, not the last. In that context, the death of the ruler cannot exile this eternity, as the regime seeks to reproduce itself by whatever means. When the death of the father is an inauguration of the beginning of dynasty rule, the son, as the only and absolute heir, takes power to establish his own dynasty. ${ }^{23}$

In that mode of rule, politics are exiled, prevented and abstained from. The dynamism of any political life in that society is fixated yet exiled. Thus, a form of political routine becomes dominant and politics lose their meaning. The Assadist regime's practices of entrenching eternity caused a state of politicide to the majority of Syrians, that is a complete destruction of any and all independent political organisations of any sort. ${ }^{24}$ "There is no room for real politics under eternity, absolutism, [and] personified power," writes al-Haj Saleh in his latest book in which he analyses the workings of Assadist rule. ${ }^{25} \mathrm{He}$ refers to this state as a process of "enslavement" in which Syrians lacked their basic political rights. ${ }^{26}$ When he was asked about the reason for joining the revolution, without any hesitation - although he knew that it might backlash on him - he answered: "I want to see Syria while it changes after I spent half a century of my life without seeing it change". ${ }^{27}$

Political eternity, in that sense, is exile from history and socio-political change. ${ }^{28}$ For al-Haj Saleh, Syrians were politically exiled because of the deprivation of their political rights and living a constant bare existence. ${ }^{29}$ However, the 2011 Syrian revolution represents a rupture that breaks this exilement of history and is an attempt to enter history after more than four decades of exile. A regime that causes exile became exiled itself as the revolution aimed to fragment its absolute sovereignty. The Assadist regime navigates its own opportunity to remain as a political actor on the Syrian scene, but not the only one, especially after foreign interventions in Syria and the emergence of Islamist militant groups. ${ }^{30}$ By this partial loss of sovereignty and entry to a socio-political history that necessitates political change and social transformation, "the Assadist state became an exile from history itself" ${ }^{31}$ The Syrian revolution is a historical moment as it broke Assadist eternal rule and forced it to move from eternity into the temporary.

This is what al-Haj Saleh means by living in exile while he was a 'citizen' in Syria: "I still find it difficult to reconcile myself to the word exile. I used to observe it with the eyes of a prisoner, then with the eyes of a 'citizen' living in Syria." ${ }^{32} \mathrm{He}$ was politically exiled inside the country, as a prisoner and as a 'citizen'. ${ }^{33}$ In al-Haj Saleh's words, it can be said that the Assadist regime was the exiling authority, located in an exiling political structure of the politics of 
eternity, which exiles Syrians from politics and history. In the following section, I discuss how al-Haj Saleh illustrates the negation of freedom through prison by juxtaposing the experience of prison with exile.

\section{Political jail as exile: exiling freedom through jail and exile}

Al-Haj Saleh juxtaposes political imprisonment with exile, the effect of displacement. If we are forbidden to come out of the house in which we live, for al-Haj Saleh, the house becomes a prison. And if we are 'imprisoned' outside the house, or the country, it is prison in the form of exile; "prison is an exile to the inside from which we are not allowed to go out, and exile is a prison in the outside from which we cannot return". ${ }^{34}$ Thus, imprisonment outside the country is dispossession of the freedom to return, and therefore exile. Imprisonment inside the country and the prohibition of coming out is also exile. Exilement here is the act of negating the freedom of going out of the prison and negating the freedom of returning to the country. In that sense, exile is a continuation of prison.

Exile was a legal punishment in colonial settings, by which natives who rebelled against colonial social and political norms in the colonies were forcibly relocated to deserted and remote areas. Exile, which was often referred to as "deportation", was a way of isolating "political undesirables" outside their county. ${ }^{35}$ Prison is a place of exiling rights and isolating "undesirables" inside the country. With the suspension of exile as a legal punishment, prison became the punishment which substitutes and equates exile. ${ }^{36}$ Both experiences are common in terms of their negation of freedom and rights, and the confinement of subjects inside and outside their countries.

The exiling act, in prison and exile, is violence perpetrated by an exiling authority - here the Assadist Syrian state. ${ }^{37}$ The brutality of political prison as an unlawful space of incarceration lies at the heart of contemporary Syrian society and its recent conflict, rendering Syria as a "space of exception". 38 Much of al-Haj Saleh's writing deals with the question of prison, as emblematic of al-Assad's rule. ${ }^{39}$ However, exilement in the Syrian context is not limited to politics of eternity, imprisonment and displacement; it can also be associated with other common phenomena in the Syrian context, such as forced disappearance, rape and oblivion since these are deployed as types of political punishment and modalities of governance.

\section{Marginalisation as exile: oblivion, rape and enforced disappearance in Syria}

Oblivion (al-mansa) is the state of not being publicly remembered or honoured and being forgotten and invisible. ${ }^{40}$ It is a state of being banished from public speech and the national memory. Oblivion is a state of non-representation, in which only the ruler is remembered and commemorated, and all Syrians are oblivionated and rendered invisible. The oblivionated (i.e. the made-absent by force) are groups of people who are dehumanised and 
humiliated, and ultimately die without being mentioned or remembered publicly. They are products of power relations, similar to exiles and the imprisoned. The oblivionated are "exiles inside their countries, outside public remembrance and the public sphere. They are unrecognized and unseen. No one thinks about them. Their narratives and stories are untold. Their voices are silenced, and their images are removed" as a result of relations of dehumanisation and humiliation..$^{41}$

Al-Haj Saleh takes the victims of the Hama massacre in 1982 as an example of an oblivionated population. In February of that year, the city of Hama was besieged by the Syrian Arab Army for 27 days under the orders of Hafez al-Assad to suppress an uprising by the Syrian Muslim Brotherhood against the regime's government. The city was heavily bombarded and large parts of the city were destroyed. The numbers of victims are still unknown. A Syrian journalist estimates that by invading the city, the army killed between 30,000 and 40,000 of the city's citizens, in addition to 15,000 missing and 100,000 expelled. ${ }^{42}$ Ismail (2018) studies the silence about the Hama violence, the unsaid, that was present in Syrians' lives, arguing that Hama functions as a pedagogy of rule and instructive of the powers of the ruler. She contends that Hama was "a gap in narratives of the Syrian experience of life under the Hafez al-Assad dictatorship" ${ }^{43}$ For al-Haj Saleh, the victims (and the witnesses) of Hama were killed twice: once in the massacre and the other by oblivionation. The 2011 revolution was against this state of invisibility, and an attempt to own politics and the public sphere. According to al-Haj Saleh, this state of oblivion is one of the causes of the revolution, which is often undermined by Western discourses about Syria (see below).

Al-Haj Saleh explicitly analyses prison torture dynamics, inspired from his time behind bars. It is important to note that the political prisoner in Syria is not an exception, but the general rule. The prison camp is an apparatus of governmental violence that structures subject-state relations in Syria. ${ }^{44}$ Al-Haj Saleh distinguishes between three types of torture: "interrogatory or investigatory torture, humiliatory-retaliatory torture, and genocidal or exterminatory torture" ${ }^{45}$ Humiliatory torture is a dominant form in Syria that seeks to exterminate its subjects and permanently enslave them in case of survival. He argues that neither society nor the state aids the prisoner in their rehabilitation after release. Actually, the state keeps the (former) prisoner in a permanent state of terror and horror by keeping them always in check. ${ }^{46}$ Genocidal torture is aimed at systematically killing the masses by multiple forms, not merely by torture, but by creating death-worlds in which the subjects are disposable and exposed to extreme conditions of hunger, disease, siege and terror. Massacres, barrel bombs, and sarin gas feature among the tools deployed by the torture machine. ${ }^{47}$ This form of torture, al-Haj Saleh argues, is one of the aspects which the Assadist regime adopted after 2011 to crush peaceful protests.

With tens of thousands of women, men and children being raped in Syria during wartime by the regime's forces and other militant groups ${ }^{48}$ rape is weaponised as pure humiliation and a genocidal tool. Rape, Al-Haj Saleh 
argues, exiles the raped self by objectifying and possessing it. It shatters and disentangles the individuality of the rape victim by literally invading and occupying their body aggressively as aspects of claiming sovereignty and control. ${ }^{49}$ For al-Haj Saleh, rape aims at not merely destroying women's bodies but also the families to whom they belong. Disrupting women's reproductive system is about disallowing their families to biologically reproduce themselves. Al-Haj Saleh asserts that rape, then, is not only about exiling women's individualities from themselves and their society, but their families and the groups to whom they belong. ${ }^{50}$

Forced disappearance is another form of exilement, added to rape and oblivion. Tens of thousands of people remain disappeared since 2011, according to Amnesty International. ${ }^{51}$ The disappeared include humanitarian workers, lawyers, journalists, peaceful activists, government critics and opponents, along with individuals detained in place of relatives wanted by the authorities. Al-Haj Saleh considers disappearance as a way of exiling the disappeared from their communities, by denying their existence. They are in a space between life and death. Disappearance also, like rape, exiles the communities to whom the missing belong by denying them the right to know where and how they are. Their families live in a state of uncertainty and are always in check. Those missing become part of the unknown. Disclosing their destinies is a way of negating them. The disappeared are in exile, in Syria.

I believe that the experience of living in hiding and being on the run can be associated with the experiences mentioned above. Al-Haj Saleh himself lived in hiding for more than two years to avoid police arrest and/or self-censorship while writing. The film Our Terrible Country shows part of his life in hiding. On a different note, in al-Haj Saleh's view, political prison and exile are interrelated and interlinked and they can be utilised as spaces of freedom and emancipation. In the following sections, I demonstrate what al-Haj Saleh means by attempts to exile exile through the processes of enjailment and exilification.

\section{Enjailment and exilification: emplacing ourselves and homing places}

Before I discuss enjailment and exilification as potentials for freedom in spaces of confinement, I briefly demonstrate al-Haj Saleh's understanding of 'freedom' which is connected to his understanding of exile, prison, self and home. For al-Haj Saleh, freedom signifies change, transgression and adventure. A free person is dynamic, changeable and flexible. Freedom is movement from one condition to another. In this understanding, coming out of the self by constantly changing it is a liberating act and a (pre)condition for freedom. Coming farther out of the self by breaking the daily routine can be not only a liberating but also a transformative experience. ${ }^{52}$ For al-Haj Saleh, the inner self of an individual can be a suffocating prison. Habits, beliefs, ideologies and traditions can be (inner) acts of confinement and detention by other means. Then, changing the self by welcoming different ideas and transgressing our beliefs is a liberating action of enlivenment and expansion, 
through hospitality towards others and their cultures. ${ }^{53}$ As the self can be a prison, it can also be a home. When we welcome others, we change them and our places, not only ourselves: "Open homeliness means to go towards others and others come to us... and we form shared homes, and the other does not remain other." 54

When a prisoner turns their prison into a home, an opportunity for personal development, al-Haj Saleh calls it 'enjailment'. ${ }^{55}$ Through the process of enjailment, a prisoner naturalises time in prison with productive activities by homing the prison and transforming it into a framework of (self-)change. ${ }^{56}$ For al-Haj Saleh, "enjailment cancels prison, deactivates it, and converts it into a space for liberation" from inner prisons. ${ }^{57}$ Prison provides the time to existentially re-think our beliefs and re-define ourselves. There is no other way for the prisoner to emancipate themselves than turning a physical prison into an avenue for liberation..$^{58}$ Enjailment, then, is "a conflict we undertake in prison against prison" by searching for freedom inside the prison..$^{59} \mathrm{In}$ his years in Syrian prisons, al-Haj Saleh himself changed and he reconsidered his views of politics. His understanding of communism became different from what it was before, and he started to oppose any dogmatic belief. ${ }^{60}$ His ways of enjailment were reading, writing, watching TV, playing cards and sleeping. The act of writing offered him a way out from prison's harsh experiences. Al-Haj Saleh talks about temporality in prison and how time stands still. Enjailment is, also, a form of owning time by turning it into one's own selfdevelopment. Like enjailment, turning exile into home is 'exilification'.

Exilification is the attempt to turn the exile home. The exiled makes from their exile an opportunity and a new beginning to resume a life that has been put on hold ${ }^{61}$ Exilification is a way of accepting the conditions and the challenges of exile, and starting new commitments for a different world; neither by isolating oneself from the new social environment in expectation of going back home nor full dissolution in the new society, in an attempt at complete erasure of the past. ${ }^{62}$ It is a state of in-betweenness, of balancing being "from there and from here" at once. ${ }^{63}$ Following this understanding, maintaining the old constitution of the self and considering it an act of resistance is counterproductive. ${ }^{64}$ "Holding on to an old self out of national loyalty is the true treason. We need in exile, as in prison, to change ourselves, to become free" al-Haj Saleh affirms. ${ }^{65}$ The relative separation of the 'old' society, traditions and habits is the only thing that liberates the exiled, according to al-Haj Saleh. ${ }^{66}$ By rendering exile into a new beginning, a different struggle added to the 'old' one in the home country, the exiled does not spend the rest of their years awaiting return. However, they try to live in exile not around it. ${ }^{67}$

Exilification can manifest itself in multiple practices. Establishing friendships eliminates the foreignness of a place and reduces its identity as exile. ${ }^{68}$ Friendships help exiles to emplace themselves in new destinations and build their identities and lives in new conditions. ${ }^{69}$ Another way of exilification for al-Haj Saleh personally is through work; writing functions as a bridge to Syria and public engagement connects him to other Syrians in exile. For him, public engagement is an attempt to build a different Syria from where he is. He takes 
from writing an identity and "a method to explain the world and to navigate in it, indeed for being in the world: a chosen nation. Because of writing... I have not suffered the problems of most exiles"..$^{70}$ In addition, learning the language of the host country familiarises the exiled with the place and makes its intensity as such less counterproductive and fosters inhabitance therein. Having a house to live in helps the exiled also to reconcile their past and accept the new conditions. Moreover, exile provides the opportunity to rethink our beliefs from inside out and ponder the path the exiled has reached so far. Also, exile can be an emancipatory experience for rethinking politics, history and progress. ${ }^{71}$

For al-Haj Saleh, exile can only be an emancipatory experience if the exiled takes it to change themselves and develop their ideas about the nature of the world. ${ }^{72}$ As movement and change are constitutive of freedom, exile is an act of and a path for freedom, however hard. It is a path for freedom as it was an effect of seeking it. Exilification is a non-national attempt at exiling exile. Nationalism and/or nation-centric practices do not exile exile. Exiling exile is efficient by exiling the nation itself, as the nation is the cause of exile. ${ }^{73}$ Nonnational exiling of exile can be manifested in multiple ways, including not taking the nation or ethnic identities as the main reference point, producing non-national representations of what home might be, or developing holistic research methodologies while investigating place-making practices from a multiscalar perspective. ${ }^{74}$ It is noteworthy to add that exilification is not an oriented, fixed process with guidelines, but a way of becoming and flourishing. In al-Haj Saleh's understanding, exile is being flexible.

It should be underlined that the processes of enjailment and exilification can only be done depending on their social structures. For example, a prisoner cannot enjail if they are exiled into notorious prisons like Palmyra or Sednaya military prisons. The refugee cannot exilify if they live in hard conditions, in a camp or a tent, in short the case of thousands of Syrians in Idlib, Lebanon, Jordan and Turkey. ${ }^{75}$ In these cases, the conditions of exile are a continuation of the experience of uprooting and dispersal.

\section{Living around exile: the liminality and (in)dependency of exile}

For al-Haj Saleh, exiles need to resist the exile's regime of temporality and spatiality. The majority of Syrian refugees do not live in camps or tents. Those living in camps, out of an overall total of 6.7 million displaced Syrians, ${ }^{76}$ are living "a suspended life". They live in the temporary, meaning that they not only live "in a strange place but [also] live in the time that separates what was before from what is after". ${ }^{77}$ They keep struggling with the space and time in which they live before and after their displacement. For other Syrians who live a more or less 'normal' life, "the past suddenly seems to be the time of freedom and the present is confusion and anxiety, while the future is a hoped-for return or a sustained confusion and struggle". ${ }^{78}$ Recognising the stuckedness of/in exile's temporality is part of exilification. ${ }^{79}$ Exile is a liminal status of being torn between the conditions of exile and a destroyed country. ${ }^{80}$ As exiled Syrians are outside their country, their personal experiences become more and 
more centred around living abroad. However, the conditions of exile make them look back for their loved ones who have been kidnapped, detained or disappeared inside - that is, they are living around 'exile' not in exile. ${ }^{81}$ This makes the autonomy of exile impossible and renders exiles not just exiles but part of simultaneous social formations. ${ }^{82}$

For al-Haj Saleh, exile is an experience of contradictions. It is dependent, as it is a new beginning. However, it is also independent because of the histories of the exiled. This combination of (in)dependency is "the essence of the experience and its source of uncertainty" ${ }^{83}$ The processes of exilification and enjailment are, then, about homing the (foreign) time not only the (foreign) places. ${ }^{84}$ The word 'exile' is not adequate to describe the case of most Syrian refugees. Exile cannot be subsumed into and limited to a certain space or time. The embodiment of the experience of exile reshapes and remakes the space-time nexus: when histories of anxiety and oppression are accumulated and materialised on an individual's body wherever they go. This is not to say that 'exile' does not have its own autonomy, characterising it with different regimes of spatiality and temporality separated from their surroundings. ${ }^{85} \mathrm{To}$ the contrary, al-Haj Saleh's account neither depoliticises nor de-historicises the experience of exile. He accounts for its particularity and personal mediation; however, he does not essentialise it as such. Then, exile is an experience, however vague, individuals find themselves identifying with. ${ }^{86}$ This experience cannot be reduced to the individual level, yet it is a multilayered, socially and politically mediated experience, situated in space and time. Looking at the social structure of the uprising that has caused exilement, al-Haj Saleh neither romanticises nor idealises the experience of exile or that of one's homeland ${ }^{87}$ His way of understanding exile grabs its causes and its effects altogether in one conjuncture. He accounts for his subjective, phenomenological experience while situating it in the social fabrics from which it erupted. In what follows, I show how al-Haj Saleh differentiates between the refugee and the exile based on his personal experiences and observations.

\section{Refugees and exiles: proximity and agency}

As he aspires for social change, al-Haj Saleh works on developing conceptual tools to analyse the situation in Syria and the Middle East ${ }^{88}$ While doing so, the question of agency is central to his writings and the way he differentiates the exile from the refugee. The figure of the refugee emerged in the wake of World War II through the management of displacement through legal structures, and humanitarian and scholarly domains. Unlike the exile, the refugee evokes multiple engagements with the state and international bureaucracies. The figure of the exile has no legal references on "the national order of things" but is connected in literary studies as an aesthetic realm of displacement and mobility. ${ }^{89}$ Both figures foreclose different histories of ways of management and administration. Moreover, as al-Haj Saleh was a refugee in Turkey, then an exile in Berlin, he adds proximity and distance, and choice to differentiate between the exile and the refugee. ${ }^{90}$ 
For al-Haj Saleh, through the language of proximity, relationships in space and the relative distance between them render, to my mind, who is a refugee and who is an exile. In mass displacement, the refugee seeks refuge in the nearest place from the conflict and awaits return. However, the exile chooses the exile where they foresee a better life and a more stable, less uncertain future. Refugeehood is the early phase of becoming an exile, as becoming an exile starts with being a refugee, not vice versa. ${ }^{11}$ All places that the exiling authority cannot reach are places of refuge and sanctuary. The further the distance and time far from home, the more exiled the refugee becomes. For example, for al-Haj Saleh, Syrians who live in the north take refuge in Turkey, those who live in the south take refuge in Jordon and Iraq, and in Lebanon for the residents of Damascus and Homs. ${ }^{92}$ When moving farther, the refugee goes beyond being forced to leave and thinks of places in which life opportunities are better. Also, the longer the refugee moves, the longer it takes to return. "It is a question of distance and time," for al-Haj Saleh. ${ }^{93}$ "With a greater distance, say somewhere like Germany, the shortest period of exile is enough to make a refugee stop thinking of return" he clarifies. The longer refugees stay, the more exiled they become.

Al-Haj Saleh does not assume a primacy of state-centric forms of political membership. His differentiation between refugee and exile status indicates that in exile there is more agency and choice than in refugeehood. For al-Haj Saleh, exile, the effect of displacement, is voluntary although forced, similar to 'self-imposed exiles'. Syrian refugees do not go to Germany seeking protection and security, but seeking a less uncertain life that can be planned and invested in. ${ }^{94}$ The purpose of this differentiation, between exiles and refugees, is to analyse the conditions and own the experiences that displaced Syrians pass through. Al-Haj Saleh re-narrates refugees' experiences without portraying them as victims of their conditions or putting them in statist discourse tied up with securitisation, humanitarianism and border control. He argues for interpreting refugees' experiences from their own points of view, in their own words, and challenges how forms of knowledge and ways of seeing refugees are open to present different views of refugee and exile conditions. While a refugee in Turkey for four years, al-Haj Saleh was a founding member of Hamish (Arabic for margin), a cultural initiative in Istanbul using art, film, and literature aimed at challenging representations of Syrians as victims, a dominant discourse in Turkish society, and to produce forms of representation that portray in graphic form refugees following the EU-Turkey refugee deal. ${ }^{95}$ According to al-Haj Saleh, this differentiation is from the viewpoints and lifeworlds of refugees and exiles themselves, to emphasise their agency, which is often exiled by displacement conditions, host communities and hegemonic discourses.

\section{The end of exile: the world of exiles, the exile of the world}

Al-Haj Saleh's critique of the victimisation and the rendering invisible of Syrians is spread throughout his writings. He offers a harsh critique towards the United Nations, its Security Council, the western left and the international 
state-centric order for their (violent) inaction towards Syria. He argues that what Syrians experience is not limited to them. Syria's crisis is no longer Syrian, it is a crisis of the whole world. The descent of peaceful revolution into war, followed by foreign interventions - by the Russians, by Iranian militias from Lebanon and Iraq, then the USA and Turkey - and the rise of ISIS and other Jihadi groups constituted what he calls the 'Syrian Question'. The Syrian Question is "the complicated entanglements between the local struggle against tyranny and religious, sectarian, and ethnic conflicts, along with all the complex and intertwined international interventions" that happened in Syria. ${ }^{96}$ The Syrian Question represents the state of the world in which it is raised, similar to the 'Jewish Question' and the 'Palestinian Question'. Syria's story is the story of the world as "democracy is in crisis all over the world and Syria is a victim of this crisis". ${ }^{97}$

The world is Syrianised and Syria is internationalised. Since the USRussian chemical deal in late 2013, which implied authorisation for the Assad regime to kill Syrians by all means except chemical weapons to not transgress the US 'red line', for al-Haj Saleh, the war in Syria has become globalised..$^{98}$ Syria has become a global symbol of injustice, apathy and amnesia. ${ }^{99}$ The exterminatory, genocidal regime is not a local problem. It is a global problem, as what happened in Syria establishes a global norm and a sovereign possibility in the world of states that can happen elsewhere. Additionally, Syria is located in an already internationalised region, the Middle East, in which global and regional powers are involved in defeating the Arab revolutions, not only Syria. ${ }^{100}$ The cluster of these forces makes of Syria a global question and the war therein is globalised.

Al-Haj Saleh writes against western representations of the Syrian revolution as simply a conflict or a civil war, as this representation obscures Syrians' right to democracy and the extremist nature of the regime. These representations are embedded in 'war-on-terror' discourses. Mainstream attention was shifted to ISIS and refugees while intentionally ignoring the regime's role in cultivating the conditions from which ISIS and the refugees emerge. For alHaj Saleh, these representations are complementary to the war machinery on the battlefield. The less than 7 million Syrians scattered around the world makes of Syria a world crisis. That view of a Syrianised world is not only on the political level, but also realised in the personal realm. Al-Haj Saleh links the destiny and the future of democracy around the world to the freedom of his loved ones, whose destinies are unknown.

Al-Haj Saleh conceptualises 'the world' as an analytical category that equates that of 'exile' and 'home'. ${ }^{101}$ Thinking of the world as an exile makes us think of all the injustices around the world, of which Syria is an example. Such injustices, for al-Haj Saleh, are interconnected and interdependent. $\mathrm{He}$ promotes a relational understanding of the global. The world of exiles is part of, and similar to, the exile of the world. In other words, exiled individuals are in the world, which is an exile itself. The exiling political structure is the world's nation-centric political structure. ${ }^{102}$ Thus, the world's dystopia/utopia is immanent and within. It is here and now, and we bring it into being with 
every action. ${ }^{103}$ That is why for al-Haj Saleh we must change the world in the world without taking higher moral stances regarding the conflicts we are part of as much as we cannot disconnect what is exile from its surrounding action. ${ }^{104}$ In that view, changing Syria is a way towards changing the world and the world's change will befall the Syrians. ${ }^{105}$ Likewise, exiling exile is by rethinking the world's state-centric political system. As the world is the exile, in other words, exiling exile is achieved by exiling today's world.

\section{Conclusion}

The world is an exile in which millions of people are differentially dispossessed. Al-Haj Saleh thinks of the world as home and exile at the same time. ${ }^{106}$ Syria is part of this world/home/exile complex, where the majority of Syrians were exiles in Syria before they were displaced after transformation of the 2011 Syrian revolution into a war. Syrians were exiles as they lived without political rights and legal protection. Hence, for al-Haj Saleh, exile is not exclusively about displacement and uprooting. Exilement, as a cluster of practices and forces, is a modality of rule which is constitutive of Assadist rule in Syria. In that sense, exilement offers analytical views on the outbreak of the Syrian revolution. I presented al-Haj Saleh's perspective on some manifestations of exilement, such as the regime's politics of eternity, marginalisation, non-representation and mass incarceration. The Assadist regime has cultivated over the years an exiling political structure through sectarianism, dynastic rule; and the practices of exilement eventually culminated in genocidal practices that have displaced millions of Syrians around the world. Al-Haj Saleh's perspective on exilification and enjailment shows the way through which exiles undo their exile by transforming exile conditions into liveable spaces.

\section{Acknowledgments}

I would like to thank Magdalena Kmak and Heta Björklund for their extensive feedback on earlier drafts of the chapter. I am grateful to the anonymous reviewers as well. This chapter builds on research I have done with the Aleppo Project at Central European University in Budapest in 2019. I am grateful to the Project's staff for supporting it. I am also thankful for al-Haj Saleh's comments on an earlier draft.

\section{Notes}

1 Enjailment is the translation of the Arabic term Istihbas, coined by the author from the word habs which means imprisonment. Istihbas (as translated by Rana Issa and Suneela Mubayi) is when a prisoner lives in prison as if it is their home. al-Haj Saleh, 2012, 202; al-Haj Saleh, 2018b.

2 The term exilification is the translation of the Arabic term istilja, from the origin luju, which is to take refuge. The author coined this term to account for exiles' lives in exile. 
3 Massouh, 2015b.

4 Massouh, 2015a, 10.

5 Massouh, 2015b.

6 Ghaddar, 2011; Parker, 2018.

7 See al-Haj Saleh, 2019d.

8 See Malkki, 1995; Said, 2000.

9 McKeever, 2020, 5.

10 Massouh, 2015a, 2015b.

11 Massouh, 2015a, 96.

12 Haugbolle, 2015, 18.

13 al-Haj Saleh, 2017b; al-Haj Saleh, 2019c.

14 Young, 2017.

15 Mbembé, 2003, 39.

16 Snyder, 2018.

17 al-Haj Saleh, 2017a.

18 al-Haj Saleh, 2019a; al-Haj Saleh, 2015b.

19 See Ismail, 2018; Dagher, 2019; al-Haj Saleh, 2015 b.

20 al-Haj Saleh, 2018c.

21 al-Haj Saleh, 2018c.

22 al-Haj Saleh, 2017a, 154.

23 al-Haj Saleh, 2018a; al-Haj Saleh, 2017a.

24 al-Haj Saleh, 2018c; Young, 2017.

25 al-Haj Saleh, 2017a, 76.

26 Hussain and Hisham, 2016.

27 Allen, 2017; Atassi and Homsi, 2014.

28 al-Haj Saleh, 2018a.

29 al-Haj Saleh, 2018a; see al-Haj Saleh, 2018c.

30 Mabon, 2017; al-Haj Saleh, 2018d; Afary, 2015; al-Haj Saleh, 2018a.

31 al-Haj Saleh, 2018a.

32 al-Haj Saleh, 2015c.

33 al-Haj Saleh, 2011.

34 al-Haj Saleh, 2019c; al-Haj Saleh, 2017b.

35 Kothari, 2012; see Sznajder and Roniger, 2009; Naguib, 2020.

36 al-Haj Saleh, 2019c.

37 al-Haj Saleh, 2017a; al-Haj Saleh, 2019c.

38 al-Haj Saleh, 2018c; Ismail, 2018; Massouh, 2015b.

39 Ismail, 2018; Massouh, 2015b; al-Haj Saleh, 2012.

40 al-Haj Saleh, 2013; Videmšek, 2014.

41 al-Haj Saleh, 2013.

42 Hadidi, 2002.

43 Ismail, 2018, viii.

44 al-Haj Saleh, 2018e; see Ismail, 2018; Mbembé, 2003; al-Haj Saleh, 2019b; Massouh, 2015b.

45 See al-Haj Saleh, 2018e.

46 al-Haj Saleh, 2012, 16; Massouh, 2015a, 85.

47 al-Haj Saleh, 2018e; Mbembé, 2003.

48 Nebehay, 2018.

49 Al-Haj Saleh also accounts for rape as a form of torture in Syria for men and women; al-Haj Saleh, 2018e.

50 al-Haj Saleh, 2018e. 
51 Amnesty International, 2017.

52 al-Haj Saleh, 2017b.

53 al-Haj Saleh, 2017b.

54 al-Haj Saleh, 2017b.

55 al-Haj Saleh, 2017b.

56 al-Haj Saleh, 2012, 202-203; al-Haj Saleh, 2017b; al-Haj Saleh, 2018 b.

57 al-Haj Saleh, 2017b.

58 Massouh, 2015b.

59 al-Haj Saleh, 2017b.

60 al-Haj Saleh, 2012, 210.

61 al-Haj Saleh, 2018b.

62 al-Haj Saleh, 2017b.

63 Darwīsh, 2007.

64 al-Haj Saleh, 2017b.

65 al-Haj Saleh, 2017b.

66 al-Haj Saleh, $2017 \mathrm{~b}$.

67 al-Haj Saleh, 2018b.

68 al-Haj Saleh, 2015c.

69 al-Haj Saleh, 2015c.

70 al-Haj Saleh, 2015c.

71 al-Haj Saleh, 2015c.

72 al-Haj Saleh, 2019c.

73 al-Haj Saleh, 2019c; see Raz-Krakotzkin, 2013; Raz-Krakotzkin, 2017.

74 See Ahmed, Castañeda, and Fortie, 2003; Çaglar and Schiller, 2018; Schiller and Çağlar, 2013.

75 al-Haj Saleh, 2018b.

76 United Nations High Commissioner for Refugee, 2019.

77 al-Haj Saleh, 2018b.

78 al-Haj Saleh, 2017b.

79 Jefferson, Turner, and Jensen, 2019.

80 al-Haj Saleh, 2015c.

81 al-Haj Saleh, 2015c.

82 al-Haj Saleh, 2015c.

83 al-Haj Saleh, 2019c; see Said, 2000.

84 See Jefferson, Turner, and Jensen, 2019; Massouh, 2015b.

85 Malkki, 1995.

86 Said, 2000.

87 Malkki, 1995, 514.

88 Parker, 2018.

89 Malkki, 1995; Said, 2000, 135; Karatani, 2005.

90 al-Haj Saleh, 2019c.

91 al-Haj Saleh, 2019c.

92 al-Haj Saleh, 2019c.

93 al-Haj Saleh, 2018b.

94 al-Haj Saleh, 2019c.

95 Rygiel and Ilcan, 2017.

96 al-Haj Saleh, 2017a, 24.

97 Young, 2017; See, al-Haj Saleh, 2017d; al-Haj Saleh, 2017e.

98 Lucha Internacionalista and İşçi Demokrasisi Partisi, 2014; al-Haj Saleh, 2015b; al-Haj Saleh, 2016; al-Haj Saleh, 2017a; Feroz, 2017; al-Haj Saleh, 
2017c; Dugaucquier and Gasparini, 2018; al-Haj Saleh, 2015a; Hamid, 2013.

99 Videmšek, 2016.

100 al-Haj Saleh, 2017c; Bishara, 2019; Teti, Abbott, Talbot, and Maggiolini, 2020.

101 al-Haj Saleh, 2018a; Young, 2017.

102 al-Haj Saleh, 2018a; al-Haj Saleh, 2019c.

103 al-Haj Saleh, 2017b.

104 al-Haj Saleh, 2017b.

105 al-Haj Saleh, 2017e.

106 al-Haj Saleh, 2019c.

\section{Bibliography}

Afary, Frieda. 2015. "Syria, Iran, ISIS and the Future of Social Justice: 'In dialogue with Yassin al-Haj Saleh'." Zamaneh Media, Accessed May 29, 2015. https:// en.radiozamaneh.com/24107/.

Ahmed, Sara, Claudia Castañeda, and Anne-Marie Fortie, eds. 2003. Uprootings/ Regroundings: Questions of Home and Migration. London: Routledge.

al-Haj Saleh, Yassin. 2011. "Prisoner of Damascus." The New York Times, April 10, 2011. Accessed July 16, 2019. https://www.nytimes.com/2011/04/11/opinion/11saleh.html/.

al-Haj Saleh, Yassin. 2012. Bil khalās yā shabāb: 16 'āman fi al-sujūn al-sūriyyah [Salvation, Oh Youths! 16 Years in Syria's Prisons]. Beirut: Dar al-Saqi.

al-Haj Saleh, Yassin. 2013. "Al-mansa al-sori... al-mansah al-sorya." [The Forgotten Syria, the Syrian Oblivion]. Al-Hewar al-Mutamadden, Accessed December 20, 2019. http://www.ahewar.org/debat/show.art.asp?aid=341905/.

al-Haj Saleh, Yassin. 2015a. "Forty-four Months and Forty-four Years: The Palestinization of Syrians and the Present World Condition." Accessed April 10, 2020.http://www.yassinhs.com/2015/01/02/forty-four-months-and-fourty-four-years-4palestinization-of-syrians-and-the-present-world-condition/.

al-Haj Saleh, Yassin. 2015b. "Syria and the World: Reactionarism is Back, and Progressing." Translated by Youssef Shayar and Alice Guthrie. Al Jumhuriya, February 19, 2016. Accessed April 8, 2020. https://www.aljumhuriya.net/en/content/syria-and-world-reactionarism-back-and-progressing/.

al-Haj Saleh, Yassin. 2015c. "On the Exiles of Syrians and Syria as Exile.” Translated by Rana Issa. Accessed May 26, 2019. http://www.yassinhs.com/2015/06/07/ on-the-exiles-of-syrians-and-syria-as-exile/.

al-Haj Saleh, Yassin. 2016. "The World's Naked Disgrace." Al Jumhuriya, August 22, 2016. Accessed April 7, 2020. https://www.aljumhuriya.net/en/content/ world $\%$ E2\%80\%99s-naked-disgrace/.

al-Haj Saleh, Yassin. 2017a. The Impossible Revolution: Making Sense of the Syrian Tragedy. Chicago: Haymarket Books.

al-Haj Saleh, Yassin. 2017b. "Freedom: Home, Prison, Exile... and the World." Translated by Rana Issa. Al Jumhuriya, March 25, 2016. Accessed May 26, 2019. http://www.yassinhs.com/2017/04/03/yassin-al-haj-saleh-on-freedom-home-prison-exileand-the-world/. al-Haj Saleh, Yassin. 2017c. "The Re-enchantment of the World." Al Jumhuriya, Accessed October 25, 2017. https://www.aljumhuriya.net/en/content/re-enchantment-world/.

al-Haj Saleh, Yassin. 2017d. "Letters to Samira (4)." Translated by Murhaf Fares. Al Jumhuriya, September 8, 2017. Accessed April 16, 2020. https://www.aljumhuriya. net/en/content/letters-samira-4/. 
al-Haj Saleh, Yassin. 2017e. "Letters to Samira (5)." Translated by Murhaf Fares. $A l$ Jumhuriya, September 13, 2017. Accessed August 11, 2019. https://www.aljumhuriya.net/en/content/letters-samira-5/.

al-Haj Saleh, Yassin. 2018a. "Al abad ka manfea mn al tareek." [Eternity as an Exile from History]. Al Jumhuriya, Accessed July 16, 2019. https://www.aljumhuriya.net/ ar/content / \% D $8 \%$ A $7 \%$ D 9\% $84 \%$ D $8 \%$ A 3 \% D $8 \%$ A $8 \%$ D $8 \%$ A F $\%$ D9\%83\%D9\%85\%D9\%86\%D9\%81\%D9\%89-\%D9\%85\%D9\%86-\%D8\%A7\%D $9 \% 84 \% \mathrm{D} 8 \% \mathrm{AA} \% \mathrm{D} 8 \% \mathrm{~A} 7 \% \mathrm{D} 8 \% \mathrm{~B} 1 \% \mathrm{D} 9 \% 8 \mathrm{~A} \% \mathrm{D} 8 \% \mathrm{AE} /$.

al-Haj Saleh, Yassin. 2018b. "Living in the Temporary." Translated by Suneela Mubayi. Al Jumhuriya, Accessed April 17, 2018. https://www.aljumhuriya.net/en/ content/living-temporary/.

al-Haj Saleh, Yassin. 2018c. "State Extermination, not a 'Dictatorial Regime'." Translated by Alex Rowell. Al Jumhuriya, June 18, 2018. Accessed April 10, 2020. https://www.aljumhuriya.net/en/content/state-extermination-not- $\%$ E2\%80\% 9Cdictatorial-regime $\% \mathrm{E} 2 \% 80 \% 9 \mathrm{D} /$.

al-Haj Saleh, Yassin. 2018d. "The World at the Fascist Moment." Translated by Suneela Mubayi. Al Jumhuriya, August 3, 2018. https://www.aljumhuriya.net/en/ content/world-fascist-moment/.

al-Haj Saleh, Yassin. 2018e. "Love, Torture, Rape... and Annihilation.” Translated by Yasser Azzayyat. Köpfe und Ideen 13, (April). Accessed April 14, 2020. https://www.wiko-berlin. de/en/wikotheque/koepfe-und-ideen/issue/13/letter-from-berlin-articles-to-samira-5/.

al-Haj Saleh, Yassin. 2019a. "Assad or Nobody!.” Translated by Sam Langer and Joel Scott. Rosa Luxemburg Stiftung Publications. https://www.rosalux.de/en/publication/id/40337/assad-or-nobody/.

al-Haj Saleh, Yassin. 2019b. "Terror, Genocide, and the 'Genocratic' Turn.” Translated by Alex Rowell. Al Jumhuriya, Accessed September 19, 2019. https://www.aljumhuriya. net/en/content/terror-genocide-and- $\%$ E2 $\% 80 \% 9$ Cgenocratic $\%$ E2 $\% 80 \% 9 D$-turn/.

al-Haj Saleh, Yassin. 2019c. "Fel manfa wa al watan wa ahalam wa alkitaba." [On Exile, Home, The World and Writing]. Al Jumhuriya, Accessed December 19, 2019. https://bit.ly/3CShx3H.

al-Haj Saleh, Yassin. 2019d. "Syria War: The Love of My Life Disappeared Six Years Ago, But Still I Cling to Hope.” Middle East Eye, December 26, 2019. Accessed April14,2020.http://www.middleeasteye.net/opinion/syria-war-love-my-life-disappearedsix-years-ago-still-i-cling-hope/.

Allen, Ira. 2017. "Falling Apart Together: On Viewing Ali Atassi's Our Terrible Country from Beirut." Screen Bodies 2, no. 2: 78-90.

Amnesty International. 2017. Syria: Tens of Thousands of Disappeared must not be Forgotten, Accessed April 14, 2020. https://www.amnesty.org/en/latest/news/2017/08/ syria-tens-of-thousands-of-disappeared-must-not-be-forgotten/.

Bishara, Azmi. 2019. "Remarks on External Factors in Democratic Transition." AlMuntaqa 2, no. 2: 40-60.

Çaglar, Ayse, and Nina Glick Schiller. 2018. Migrants and City-Making: Dispossession, Displacement, and Urban Regeneration. Durham: Duke University Press.

Dagher, Sam. 2019. Assad or We Burn the Country: How One Family's Lust for Power Destroyed Syria. New York, Boston, London: Little, Brown and Company.

Darwīsh, Mạ̣mūd. 2007. "Edward Said: A Contrapuntal Reading." Translated by Mona Anis. Cultural Critique 67, no. 1: 175-182.

Dugaucquier, Matilde, and Mauro Gasparini. 2018. "Interview with Yassin Al-Haj Saleh." International Viewpoint, Accessed February 5, 2018. https://internationalviewpoint.org/spip.php?article5361/. 
Feroz, Emran. 2017. "Syria, The Left, and The World." Al Jumhuriya, Accessed April 6, 2017. https://www.aljumhuriya.net/en/en/the-role-of-the-intellectual/syria_the_ left_and_the_world/.

Ghaddar, Hanin. 2011. "Talking to Syrian dissident Yassin Al Haj Saleh. Activist in Hiding." Now Lebanon, Accessed September 8, 2011. https://ademocracynet.com/ index.php?page $=$ news \&action $=$ Detail $\&$ id $=4354$

Hadidi, Subhi. 2002. "Bashar Assad Teaches Visiting Members of U.S. Congress How to Fight Terrorism." The Middle East Media Research Institute, January 16, 2002.Accessed April13,2020.https://www.memri.org/reports/bashar-assad-teachesvisiting-members-us-congress-how-fight-terrorism/.

Hamid, Shadi. 2013. "The U.S.-Russian Deal on Syria: A Victory for Assad." The Atlantic, September 14, 2013. Accessed April 7, 2020. https://www.theatlantic.com/ international/archive/2013/09/the-us-russian-deal-on-syria-a-victory-for$\operatorname{assad} / 279680 /$.

Haugbolle, Sune. 2015. "Moving through the Interregnum: Yassin al-Haj Saleh in the Syrian Revolution." Middle East Journal of Culture and Communication 8, no. 1: 13-36.

Hussain, Murtaza, and Marwan Hisham. 2016. "Syria's 'Voice of Conscience' Has a Message for the West.” The Intercept, October 26, 2016. Accessed April 7, 2020. https://theintercept.com/2016/10/26/syria-yassin-al-haj-saleh-interview/.

Ismail, Salwa. 2018. The Rule of Violence. Cambridge: Cambridge University Press. Jefferson, Andrew, Simon Turner, and Steffen Jensen. 2019. "Introduction: On Stuckness and Sites of Confinement." Ethnos 84, no. 1: 1-13.

Karatani, Rieko. 2005. "How History Separated Refugee and Migrant Regimes: In Search of Their Institutional Origins." International Journal of Refugee Law 17, no. 3: 517-541.

Kothari, Uma. 2012. "Contesting Colonial Rule: Politics of Exile in the Indian Ocean.” Geoforum 43, no. 4: 697-706.

Lucha Internacionalista and İşçi Demokrasisi Partisi. 2014. "Yassin al-Haj Saleh: 'The International Left is Suffering a Major Crisis'." SocialistCore.org. http://www. socialistcore. org/?p=493/.

Mabon, Simon. 2017. "Sovereignty, Bare Life and the Arab Uprisings." Third World Quarterly 38, no. 8: 1782-1799.

Malkki, Liisa H. 1995. "Refugees and Exile: From 'Refugee Studies' to the National Order of Things." Annual Review of Anthropology 24, no. 1: 495-523.

Massouh, Firas. 2015a. Searching for Salvation: Yassin al-Haj Saleh and the Writing of Modern Syria. MA Thesis, University of Melbourne.

Massouh, Firas. 2015b. "The Beast of Syrian Modernity: The Prison in the Writings of Yassin al-Haj Saleh.” Arena Journal 43/44. https://search.informit.org/ doi/10.3316/ielapa.512541270815038/.

Mbembé, J.-A. 2003. "Necropolitics." Translated by Libby Meintjes. Public Culture 15, no. 1: 11-40.

McKeever, David. 2020. Exiled Activism: Political Mobilization in Egypt and England. London: Routledge.

Naguib, Rim. 2020. "The Ideological Deportation of Foreigners and 'Local Subjects of Foreign Extraction' in Interwar Egypt”. Arab Studies Journal 28, no. 2 (Fall). Accessed December 13, 2020. https://www.jadaliyya.com/Details/42065/.

Nebehay, Stephanie. 2018. "Thousands of Women, Men, Children Raped in Syria's War: U.N. Report.” Reuters, March 15, 2018. Accessed April 14, 2020. https://www. reuters.com/article/us-mideast-crisis-syria-warcrimes-sexual-idUSKCN1GR1PZ/.

Parker, Thomas. 2018. “On Syria's Impossible Revolution.” Bosphorus Review of Books. https://bosphorusreview.com/on-syrias-impossible-revolution/. 
Raz-Krakotzkin, Amnon. 2013. "Exile, History and the Nationalization of Jewish Memory: Some Reflections on the Zionist Notion of History and Return." Journal of Levantine Studies 3, no. 2: 37-70. Accessed April 15, 2020. https://levantine-journal.org/product/exile-history-and-the-nationalization-of-jewish-memorysome-reflections-on-the-zionist-notion-of-history-and-return/.

Raz-Krakotzkin, Amnon. 2017. "Exile Within Sovereignty: Critique of 'The Negation of Exile' in Israeli Culture." In The Scaffolding of Sovereignty: Global and Aesthetic Perspectives on the History of a Concept, edited by Zvi Ben-Dor Benite, Stefanos Geroulanos, and Nicole Jerr, 393-420. New York: Columbia University Press.

Rygiel, Feyzi Baban, and Kim Suzan Ilcan. 2017. "Playing Border Politics with Urban Syrian Refugees. Legal Ambiguities, Insecurities, and Humanitarian Assistance in Turkey." Movements. Journal for Critical Migration and Border Regime Studies 3, no. 2: 81-102. Accessed January 17, 2020. http://movements-journal.org/issues/05.turkey/06.baban,ilcan,rygiel--playing-border-politics-with-urban-syrian-refugees.html/.

Said, Edward W. 2000. Reflections on Exile and Other Essays. Cambridge, MA: Harvard University Press.

Schiller, Nina Glick, and Ayse Çağlar. 2013. "Locating Migrant Pathways of Economic Emplacement: Thinking Beyond the Ethnic Lens." Ethnicities 13, no. 4: 494-514.

Snyder, Timothy. 2018. "Vladimir Putin's Politics of Eternity." The Guardian, March 15, 2018. Accessed April 9, 2020. https://www.theguardian.com/news/2018/mar/16/ vladimir-putin-russia-politics-of-eternity-timothy-snyder/.

Sznajder, Mario, and Luis Roniger, eds. 2009. The Politics of Exile in Latin America. Cambridge: Cambridge University Press.

Teti, Andrea, Pamela Abbott, Valeria Talbot, and Paolo Maggiolini. 2020. Democratisation Against Democracy How EU Foreign Policy Fails the Middle East. Cham: Palgrave Macmillan.

United Nations High Commissioner for Refugee. 2019. Global Trends - Forced Displacement in 2018. Geneva: United Nations High Commissioner for Refugee. https://www.unhcr.org/globaltrends2018/

Videmšek, Bostjan. 2014. "The Hat of Invisibility”. PULSE, Accessed May 13, 2014. https://pulsemedia.org/2014/05/13/the-hat-of-invisibility/.

Videmšek, Boštjan. 2016. "Yassin al-Haj Saleh: 'Syria is a Unique Symbol of Injustice, Apathy and Amnesia'." Chronikler, Accessed January 20, 2016. http://chronikler. com/middle-east/iraq-and-the-levant/yassin-al-haj-saleh/.

Young, Michael. 2017. "The Triumph of Politicide." Carnegie Middle East Center, Accessed July 17, 2019. https://carnegie-mec.org/diwan/72850/. 
$\Rightarrow$ Taylor \& Francis

Taylor \& Francis Group

http://taylorandfrancis.com 


\section{Part II \\ Refugee Scholarship and Scholarly Identity}


$\Rightarrow$ Taylor \& Francis

Taylor \& Francis Group

http://taylorandfrancis.com 


\title{
5 Exile and emigration from the Third Reich
}

\author{
Stages and results of research in Germany
}

\author{
Alfons Söllner
}

It is certainly no exaggeration to say that the Hitler dictatorship caused lasting damage to the collective memory of Germans. While the Holocaust has emerged ever more clearly as the traumatic centre of historical consciousness, political expulsions could be consigned to the periphery, though they maintained an underground relationship with this centre. But in certain respects one can also reverse the picture: Since exile and emigration, however much they were a humiliating and violent experience, was an escape from physical destruction, the survivors represented a moral accusation against a nation of murderers almost more directly than the dead, who were condemned to silence. It was the philosopher Friedrich Nietzsche who said that human knowledge always results from a secret equilibrium between remembering and forgetting ${ }^{1}$ - exile and emigration offer a highly favourable opportunity to explore this secret.

In the following chapter I will ask in what way political exile and emigration became part of the historical consciousness in post-war-Germany, how its status changed over half a century and not least what this change indicates for the development of political culture. To be sure, Exilforschung, as professional historiography, was and is a particularly ingenious and artificial form of remembering, but it also remains part of the general, the collective memory. Insofar as it was both object and subject of cultural and political development, the image of exile and emigration consequently became both reflex and reflection of a changing political culture. And this ambiguity may, in turn, serve as a preliminary elucidation of the purpose of this article, in terms of not only what émigrés thought, argued or published on their country of origin functioned as a very well-known critical instance of historical consciousness, but also scholarly treatment of this subject. The scientific "re-presentation" of exile and emigration can be seen as a peculiar kind of mirror of reality in post-war-Germany.

When sketching the changing image of this section in history, I will confine myself on the one hand to the western part of the divided nation; on the other hand, I will concentrate on a particularly sensitive sector out of the wide and disparate range of exile and emigration. It was especially the émigré social and political scientists, who had already formed as a critical group in the 1930s and in the 1940s tried to become, in the context of the western allied politics, an agent for future development in Germany and Europe. Although their practical influence finally proved limited, it was their intellectual and scholarly 
legacy which in the long run became an influential and powerful factor. Three different stages of research and publication can roughly be distinguished:

I From silence to politicization - the 1960s and 1970s

II The professionalization of research - the 1980s and 1990s

III The pluralization of methods - The years after 2000

\section{The origins - the adenauer era and student movement}

The 1950s and early 1960s in West Germany are in respect to politics often described as the bleierne Zeit (leaden time) of the Federal Republic - Otto Kirchheimer, for instance, spoke of a politische Käseglocke (bell jar) and Karl Löwenstein of a Demokratur; both émigré political scientists were referring to the semi-authoritarian Adenauer regime in internal politics and the frozen period of the Cold War in foreign politics. In fact, metaphors like these are useful for characterizing the hybrid relationship of continuity and renewal which, more than anything else, distinguished the political culture of this era. But such characterizations are only really telling when articulated in politico-psychological categories, as Theodor W. Adorno and later Alexander Mitscherlich did: the post-war years were a time when the horrors of the recent past were imminently present on the one hand, and reinterpreted or denied on the other. In any case, they were overlaid with a strong taboo. What is obvious in the way the Holocaust was dealt with also applies in a weaker, yet analogous form to exile and emigration: "emigrant" was a denunciatory insult in a political arena that enabled prominent armchair criminals from the Hitler era to regain official positions. ${ }^{2}$

This ambivalent constellation had sub-institutional consequences and was demonstrated, for example, by the strange shadow existence of émigré social and political scientists who had returned to the Federal Republic. On the one hand, there was a thoroughly impressive presence of former emigrants which was not confined to vague ways of reception or appeals to guilty conscience, but had taken the concrete form of a limited remigration. The remigration rate of social scientists was between 25 and 30 per cent, significantly higher than the general average and especially Jewish remigration, but also higher than that of natural scientists. The early return of the so-called Frankfurt School was definitely initiated as an act of political reparation, even though half their former colleagues chose to remain in the USA; returning émigrés were also active in other centres of sociology in the Federal Republic, such as René König and Alphons Silbermann in Cologne, who managed to some extent to create a counterweight to the continuity of conservative sociology. Relatively speaking, the greatest influence of returned emigrants (and remaining émigrés) was probably on the founding and establishment of West German political science - especially at Berlin's Free University. But after a time returning émigrés also managed to gain founding or leading positions in Freiburg, Munich and Hamburg, thus contributing substantially to the establishment of political science - on the Anglo-Saxon model - as an autonomous discipline in opposition to the tradition of German Staatswissenschaft. ${ }^{3}$ 
Yet this is only one side of a cultural setting that was in essence deeply contradictory - in this case, academic culture. The other side remained under the spell of a political and social taboo which was even more hermetic because often returning émigrés themselves helped to maintain it. One could say with some emphasis that the returning émigrés only had the right to be present to the extent that they virtually neutralized, relativized or even deliberately ignored their own political and personal pre-history in the interwar period, although it had often been formative for their academic work. It is well known how anxious Max Horkheimer was, despite his post as the celebrated rector of Frankfurt University, not to be stigmatized again as a "Jewish Marxist Intellectual" in the anti-communist milieu of the 1950s. And if we look at the leading figures in political science in Berlin who were close to social democracy - Ernst Fraenkel, Ossip K. Flechtheim and later Richard Löwenthal - we cannot fail to notice their silence about their own biographical and theoretical origins. Their declared and militant anti-fascism would have been sufficient provocation for the practice of what the sociologist Hermann Lübbe called the kommunikative Beschweigen ("communicative hushing-up") of the Nazi past. ${ }^{4}$ Other leading émigré political scientists, such as Eric Voegelin or Arnold Bergsträsser, had not really freed themselves from the tradition of German cultural conservatism even in exile, and were now able to emerge as particularly strong pillars of continuity of this tradition because they had no guilty past. But, all in all, there is a remarkable common factor among this first generation of émigré social scientists, whether they returned or not. With the sole exception of Hannah Arendt, they kept the Holocaust, the darkest background to emigration, out of the arena of public debate.

We can only glance here in passing at the different, yet in some ways similar development in the German Democratic Republic. ${ }^{5}$ Of course, there was a fundamental difference, in that emigration and exile were not only a constantly topical element of political consciousness but also, on a par with the communist resistance, actually became a core feature of "anti-fascism" and were thus incorporated into the official ideology of the communist-ruled state. But this boiled down to emigration being instrumentalized for the legitimacy problems of a party dictatorship primarily based on external support - with all the consequences that are bound to follow in a society with notorious deficits of legitimation. Communist exile was normatively overplayed and the dark side of the Stalinist era were blended out, so that returning émigrés from the West easily came under suspicion of political disloyalty. It is hardly a coincidence that it was former exiles from the West - including Ernst Bloch and Hans Mayer - who made spectacular departures from the GDR before and after the building of the Berlin Wall. But there were also partial dissidents, such as Jürgen Kuczynski, Stefan Heym and Alfred Kantorowicz, who could hold out inside the country, not least because the collective commitment to the memory of political exile gave them a kind of protection.

There is no clearer indication that the peculiar blackout of emigration led to its de-politicization than the leap into a new phase for the culture of the West German: the Wirtschaftswunder of the 1950s was followed and 
disturbed by the student movement in 1967/68. In fact, the student movement, though it had precedents in the anti-nuclear movement of the late 1950 's, acted as a political beacon primarily because its provocative stance tore through the veil of political consciousness. The powerful effect of this provocation can be seen not least in the deeply defensive reactions that students in Berlin and Frankfurt got from their academic teachers - Adorno, Ernst Fraenkel and Richard Löwenthal kept their distance in troubled formulations. The most pointed and well-known was Habermas' ambiguous term "Linksfaschismus" (left-wing fascism). The student movement was both a complex and an international phenomenon, but in West Germany it was articulated more than elsewhere as a generational conflict between silent fathers and their sons and daughters insistently demanding explanations. Behind the conflicts lay the deep-seated question of the Nazi past. ${ }^{6}$

We have to look for cultural-psychological connections like these to understand the changed, more direct political status that emigration took on in German historical consciousness after 1968. Because the émigrés seemed to be "better", anti-fascist fathers, exile represented not only the "other" but the "better" Germany. ${ }^{7}$ In terms of the history of ideas this means the forced rediscovery of the politico-economic theory of fascism, which replaced the theory of totalitarianism that had been "unmasked" as anti-communist. The newly-awakened interest in emigration was an integral, if not functional, part of a political project. This is shown not least in a change in terminology: the rather apolitical term "emigration" was replaced by the political one, "exile". And in this same context it becomes clear why it was more or less exclusively the left-wing exponents of exile or the leftist groupings and aspects of emigration culture that attracted the most attention, while the wide variations of the spectrum as a whole remained unnoticed. This biased perspective lasted until well into the 1970s, when the student movement had long since collapsed without achieving its aims, and still left clear traces in the sphere of prima facie "value-free" academic research.

A good example of this is the turn that the reception of the Frankfurt School took in the 1970s: whereas its image in the 1960s had still been marked by esoteric-philosophical self-interpretation, as clearly represented in Adorno's late works, this varnish virtually cracked under the students' attacks - and the renounced early phase of the Institute for Social Research came to the fore: the rhetoric of revolutionary theory, its camouflage in the terminology of "critical theory" and the economistic foundation of social psychology and cultural criticism. The representative position previously held by Adorno was taken over in Germany too by Marcuse, because he seemed to embody this political tradition more convincingly. The historical reception, which made an intense impact in the 1970s, was still in the slipstream of the "Cultural Revolution" on the one hand, but on the other it was already ebbing away into academic industry - it submitted to epistemological interests in the sociology of knowledge or the history of ideas and believed this methodological refraction was the best way to salvage the legacy of the Frankfurt School. But it is interesting that a broad historical account such as Martin Jay presented in the USA was first published in Germany only in the mid-1980s (by Rolf Wiggershaus). ${ }^{8}$ 
Another development must at least be mentioned because it displays certain thematic parallels, and is also a notable methodical contrast to the 1980s. When people in Germany today talk of Exilforschung, in the first place they mean the rapidly growing number of studies and publications devoted since the beginning of the 1970's mainly to two partly overlapping thematic fields: on the one hand, the political exiles with their groups, strategies and aims and on the other, the artistic, especially the literary, exiles. ${ }^{9}$ Even where the political connotations were underplayed in accounts by contemporary historians and literary scholars, a certain bias remained in force which a telling title called "with their face turned towards Germany" (Mit dem Gesicht nach Deutschland). ${ }^{10}$ In the foreground was the interest in Germany's fate under National Socialism and correspondingly the anti-fascist commitment, which was indeed typical of broad sections of the political and literary exile community; in turn, this political orientation was best illustrated by a focus on those celebrities who had most vividly portrayed the "experience of exile", that is, also the suffering of exile.

I do not know if it is a malicious accusation to see these epistemological interests in exile research not just as the belated correction of a one-sided historical picture, but also as something like a "need to bring things back home", a reclamation of the cultural "losses of emigration", as it were. If this were the case, then the legitimate desire to finally take on fully the legacy of emigration would have been superseded in the very moment of its fulfilment by a nationalistic idea of cultural property - in clear contradiction to the cosmopolitan spirit of prominent figures like Thomas Mann, Albert Einstein and others. Whatever the case, it was no coincidence that it was the 1970s when an émigré, Willy Brandt, became head of government, and when academic research began to open up to the whole breadth and depth of the political, literary and scientific emigration: the German Research Foundation (Deutsche Forschungsgemeinschaft) set up its own focus on exile research, and at the Munich Institute of Contemporary History (Institut für Zeitgeschichte) a systematic work of collection was begun which would bear fruit ten years later in the "International Biographical Dictionary of Central European Emigrés", a collective work by German, American and Jewish researchers whose weighty volumes documented around 9,000 biographies, making available a wealth of data and information. ${ }^{11}$

This is the appropriate point to add an ironic footnote to the inner-German rivalry about the legacy of emigration; in the GDR, at the same time as the late awakening of West German research, there appeared an early - and premature - general depiction of exile, as pretentious as it was one-sided, because it was totally bound by the communist party conception of Erbe (legacy) ${ }^{12}$ The highly biased feature of East German research on exile and emigration was evident in two corresponding tendencies: in over-rating the returnees from Moscow, especially the intellectuals who came with the "Ulbricht group", and in under-rating the anti-Semitic instrumentation of Nazi policy. 


\section{The professionalization of research - the 1980s and the 1990s}

It should not be regarded as misplaced arrogance in relation to important impulses, particularly from US research, to state that truly professional research on emigration got under way in Germany only in the 1980s. As indicators, one might discern the emergence of three major trends, and above all their dynamic pairing:

1. research evolved its own form of organization;

2. research started on the path towards specialization;

3. reflection on theories and methods came to the fore;

1. To start with organizational innovations: the Deutsche Forschungsgemeinschaft, the official research organization in the Federal Republic, extended its scope to cover research on emigration, and the Volkswagen Foundation developed a new focus - which meant specialized selection committees and generously-funded programmes. The Gesellschaft für Exilforschung was established as an interdisciplinary organization that held regular conferences and, since 1983, has published their results in its own annual review, the Jahrbuch für Exilforschung. Along with a large number of individual initiatives in research and publishing, the Zentrum für Antisemitismusforschung was founded in Berlin. Its first director, Herbert A. Strauss, maintained a programmatic and continuous involvement in emigration research. The other two points mentioned above are useful for making at least a rough sketch of the direction of development in more recent West German research on emigration:

2. The most important thematic area in the 1980s emerged first from an obvious gap in research and rapidly became the subject of both fundamental and specialized investigations. I am referring to the Wissenschaftsemigration, namely, emigration of scientists and scholars. ${ }^{13}$ The research strategy was aimed towards intensive and extensive expansion. Not only could the whole spectrum and previously unknown quantity of the "cultural exodus" 14 in general be revealed, but also the specific quality of the émigré scientists could be explored in detail: their differentiation within individual disciplines, the constellation of the various academic faculties (natural and social sciences and the humanities), as well as the consequences of expulsion for the underlying structure of entire cultures of knowledge. The shift in the focus of research - and this connection is especially important - meant not only a characteristic shift of epistemological interest: from political and literary "exile" to the rather more neutral subject areas and the social milieus of "emigration". Almost more important were the resulting changes in the apparatus of cognition, the concepts and methods that have to be specially suited for examining scholarly emigration. In any case, that it could now come to an alternative and momentous discussion of methods was also linked with the fact that the archival and empirical preconditions had significantly 
improved. In the first place we should point to the publication of the "International Biographical Dictionary of Central European Émigrés".

3. Finally, concerning methodological innovations, again three tendencies seem to be of major significance:

a. The move from individual to collective biographies: It was now possible, not least because of the aggregated data of the International Biographical Dictionary, to locate the fate of émigrés, which had always been individual, within wider contexts, whether scientific disciplines such as physics, psychology, political sciences, and the like, or institutional contexts such as the New School for Social Research or the Manhattan Project, or, finally, cultural émigré milieus such as those in New York and Los Angeles.

b. The move from the history of ideas of exiles to the social history and the real impact of immigrants: While older research on exiles remained fixated on the country of origin and was thus a "discourse of loss", research into the emigration of scholars had to concentrate on the countries where they settled. The paths they took to get there, the forms of integration, for example, social obstacles or political opportunities for émigrés, and the long-term impact in specific contexts of practice, such as their success or failure in one or another scientific discipline all this now came to the fore. The concept of "acculturation" became a decisive key category, to be carefully distinguished from other concepts like "assimilation" or "nationalization" (e.g. "Americanization"). ${ }^{15}$

c. Research on emigration became in large measure part of a general history of culture and simultaneously of the history of migration in the 20th century. This created opportunities, but also brought risks: On the one hand, a factual and temporal broadening of perspective emerged - the effect of scholarly emigration in particular may have remained bound to the national context, but from the start it had a special international reverberation; the history of émigré impact meant placing it in longer-term contexts whose boundaries no longer coincided with the boundaries of exile - 1933 and 1945. On the other hand, this new "contextualization" of emigration threatened to cause the disappearance of the particular features of "forced migration", namely its highly specific cultural and political connotations. ${ }^{16}$

Did this multiplex turn in emigration research run parallel with tendencies towards "normalization", in the sense of the levelling out of National Socialism in the German historical consciousness? We know that these were the catchphrases with which the so-called "Historians' Quarrel" towards the end of the 1980s was fought. ${ }^{17}$ Although this debate evoked by Jürgen Habermas was started by Ernst Nolte's assertion of a causal nexus between Gulag and Holocaust, which was almost unanimously denied by the community of professional historians, in a wider sense it was also about the legitimacy of adopting a more general historical perspective. The first thing one notices is that this debate contained no direct reference at all to the emigration research currently 
being done. Was this an indication of the marginality of emigration compared with the Holocaust, as mentioned at the beginning - or was it now objectively justified and politically safe to situate emigration in wider cultural and international contexts in the whole course of a century whose continual eruptions of violence were impossible to deny and are clearly still not at an end?

In order to answer this question let me turn to the changed image of the group of political scientists. The fact that it is possible today to bring together such widely divergent political and scientific figures as Hannah Arendt, Franz L. Neumann, Arnold Brecht or Hans J. Morgenthau under one and the same "historical umbrella" - with good methodological reason, I assume - is already a demonstration of the epistemological progress in understanding emigration. What we could call the "disciplinary fencing-in" of émigré culture, which was not at all unified, was both a result of a cognitive abstraction and of research into multifarious contexts of praxis, the discovery of their political connections and the interpretation of recalcitrant intellectual biographies to achieve an internally coherent picture. And only from the synthesis of all this could the evolutionary idea finally emerge that the émigré political scientists have contributed as a group to build something like a viable bridge between the "German" tradition of legalist Staatswissenschaft on the one hand and the "Anglo-Saxon" tradition of political science on the other. ${ }^{18}$ It is also immediately evident that telling the story of emigration like this is only possible if you look at the internationalization of knowledge as the real dynamic factor of the modern history of science. In the case of the émigré political scientists there is also the fact that this bridge-building - more than in fields like biochemistry or history of art-had direct political consequences, because it was intentionally designed to integrate the Federal Republic of Germany into the cultural system of the Western democracies.

A few remarks must suffice to sketch the change in the scene around the year 1989. So difficult it was - and still is - to give a reliable diagnosis of German political culture and its rapid progress especially in the "unification crisis", as historians have dubbed it, one might nevertheless risk following up one single and sensitive question: Was the moment of reunification only the manifestation of short-term frictions which arose from the enormous - and unexpected - social, economic and cultural problems of bringing together two very different states, or has it in fact contributed to a tangible and lasting "re-nationalization" of political consciousness on the way to a "Greater Germany"? I will confine myself only to a disparate pair of indicators, in order to combine them for a cautious judgement: one speaks for the second alternative, the other more for the first. Whereas the growth of obvious hostility to foreigners in 1992/93 was a strong expression of a "new nationalism", violent and aggressive as it came to the fore, it is interesting to see that shortly after researchers of exile and emigration also made a significant "turn home again": They started to study the ways and perspectives of émigrés who decided to return to post-war Germany, thereby opening up a completely new chapter, which soon became an expanding and special field of research. ${ }^{19}$ However, this turn had nothing to do with "re-nationalization", insofar as the complexity of exploring historical 
facts and drawing theoretical perspectives became not lower but even higher. Remigration as a new field of research became one possible (but not always happy) ending to a long and wearisome story. Indeed, one might even say that this new concentration produced a clearer picture of the anti-national, or the inter-national, networking of people and thought which exile and emigration meant in the longue durée of the 20 th century.

\section{Methodological pluralism - normal science development after 2000}

Every overview of a period of some length becomes more difficult when arriving at the actual observer. Judgement tends to become more subjective or even biased. So, before going into the details of the third period which can be differentiated within the development of emigration and exile as a scientific subject, I feel obliged to offer a personal reflection. As already manifest in the sections before, I myself was continuously part and parcel of the business I try to describe here, which, of course, implies a certain partiality or even some blind spots within my analysis: As my book on the German-Swedish author Peter Weiss, published in 1988, was an original product of the first period, ${ }^{20}$ so my volume on the emigré political scientists, published in 1996, in many respects applied the methodological design so typical of the second period. ${ }^{21}$ And what I have later brought out in two further volumes with collected articles reflected, probably without clear intention, other and tentative aspects of a research field undergoing rapid change. ${ }^{22}$ Here, as before, I might only have reacted to general trends which now stood for opening up the historical horizon, setting emigration and exile into a wider range of ideas, and probing a methodological pluralism so typical of the postmodern era.

However, one fact is beyond any doubt and must be placed at the threshold of the new century: The high noon of exile and emigration research in Germany was followed by a gradual decline. For example, the great desire of many committed members of the research community remained unfulfilled, namely that their subject and their approach should be institutionalized. The Deutsche Forschungsgemeinschaft had already stopped making this its focal issue, and there has been no success in establishing a new institute or at least a chair at any German university which would be exclusively dedicated to teaching and research in this field. There were also no discernible new impulses to investigate the by no means small remigration to East Germany, though they could have been stimulated by the opening of East European and Russian archives. Among other reasons, this was because GDR historical scholarship had been almost completely liquidated (abgewickelt). If you look at which new publications or new collected editions were now attracting attention, it tended to be those by conservative figures from the spectrum of Western emigration, such as Leo Strauss or Eric Voegelin. ${ }^{23}$ But in any case, their publicity remained restricted to an academic audience, for example if you compare it with the waves caused by the Holocaust debate, as provoked by the book by Daniel Goldhagen. ${ }^{24}$ 
In order to beware off the danger of a biased critique of the broad and expanding literature after 2000, which by now can't easily be surveyed, let me point to a highly competent and dense survey of the whole field. Its author is Claus-Dieter Krohn, chairman for many years of the Gesellschaft für Exilforschung (Society for exile research) and editor of the Jahrbuch für Exilforschung, his piece was published in 2012 and is a kind of authoritative summary. ${ }^{25}$ And for the rest of the story I would like to confine my perspective to a sub-field of exile and emigration which came rather late into the focus of my own research, ${ }^{26}$ but which seems significant not least because it stands for a certain comeback from the initial period and continues into the present. I speak of the interwar period, with France as the first country of arrival, and especially the role which Paris played as the prototypical, if not the archetypical place of the German intelligentsia in exile.

In other words: While - or although - the image of the exile epoch has considerably changed, should France, and in particular the metropolis Paris, after and despite all the differentiation of research, still be considered the locus classicus of the epoch of exile? As is well known, the French capital was always not only a sentimental component of every ambitious German educational career, but also the political vanishing point of the German leftist intelligentsia. But only the collapse of the Weimar Republic and National Socialist persecutions gave rise to that new, equally fascinating and terrifying scenario in whose depiction contemporary history and specifically exile research necessarily had to participate; for the history of ideas, the "capital of the 19th century" (Walter Benjamin) had become the quarry from whose fragments the so-called interwar period had to be put together in a laborious look backward.

I shall begin with the Handbuch der deutschsprachigen Emigration 19331945 (Handbook of German-speaking emigration 1933-1945), already mentioned, which was published in 1998 and follows a six-part matrix. After a general introduction, in Section II the different countries of refuge are treated, then, in Sections III-V the issue is subdivided into political exile, academic emigration, and literary-artistic exile, then finally the topics of remigration and the reception of exile after 1945 are addressed. On France, the article by Barbara Vormeier is pertinent; it is based on a bibliography of more than 100 titles and is also far and away the longest of the 36 country descriptions (longer even than the section on the USA!):27 How does this thick volume, the encyclopaedia of exile and emigration, indeed present France as a country of exile?

Beginning with the waves of flight since 1933, the estimated numbers, and an attempt to divide exile into periods, French asylum policy is first sketched: from initial openness, through the "normal" frictions of integration and labour in the mid-1930s, to the step-by-step tightening of regulations, and finally to the policy of internment starting in 1939/40. Presented in detail are the emigrants' political and social organizations whose spatial centre was in Paris: their common aim was the political struggle against Hitler, while the means of that struggle were of a limited, purely cultural kind. The spectacular 
cultural-political actions are depicted in detail - from the Schutzverband deutscher Schriftsteller (Protective association of German writers), through the Kongress zur Verteidigung der Kultur (Congress for the defence of culture), to the briefly successful establishment of a deutsche Volksfront (German popular front). But there remains no doubt, not least because of the concealed dominance of the communists, that this coalition across political camps was already illusory in the middle period and then became even more illusory after 1938, when international politics had shifted to a defensive course against Hitler's plans for expansion. The brief flare-up of the Paris-centred cultural struggle against Hitler thus ended in defeat and collaboration, which left emigrants, and especially the Jews among them, only the alternative between a second flight and deportation into certain death.

The historical-political compactness of this depiction of scenario by a German scholar of German philology in France is impressive. But when continuing to the volume Fluchtziel Paris (Flight destination Paris), ${ }^{28}$ which was published in 2002, you get an even greater reach but also a complex image: first presented is the entire spectrum of the methods and perspectives now available in research then, second, this spectrum is used to emphasize Paris as the very centre of European exile. Therefore, it is the unambiguous message of this volume gathering the results of an international congress: that Paris was indeed - for example, in comparison with Prague or Moscow - the most spectacular location of everything that the German community in exile had to offer in political and cultural prominence and above all in hopeful cooperation between politics and culture. But this is just one side of the story.

The other side is equally present, or even becomes obtrusive, when the gleaming surface of feverish activity and cultural-political declarations are punctured. And here the doldrums of the everyday life of exile, the worries and straits of survival, but also the never-ending distrust among the leftist groups and the Moscow-obedient Comintern's external control over the communist actors show that, while the "myth of Paris" existed as an initial wishful projection (whether as a relic of the 19th-century educated classes or as identification with the bohème in the cafés of Montparnasse), its gruesome disenchantment was not long in coming. The euphoria of the front populaire between 1936 and 1938 and the final phase of the Third Republic were equally brief: the Grande Nation was no longer able to recover before the Wehrmacht marched into Paris.

It is revealing to cast a glance from the standpoint of this disillusionment onto the 2012 yearbook for exile research, not least because here, after almost 30 years, the editors sum up and pass on the baton to the younger generation of researchers. The title of the volume as such - Exilforschungen im historischen Prozess $^{29}$ (Exile research in the historical process) - is already interesting; significant features are both the plural, which once more reconstructs the various national traditions from which exile research arose, and an increased will to further "historicize" the epoch, which does not mean making the singularity of the exile epoch as a whole disappear, but letting its colourful aspects blossom along with the possibilities of interdisciplinary interconnection. 
The summarizing article Exil in Frankreich ${ }^{30}$ (Exile in France) is especially significant in this regard, because, without much regret, it leaves behind the political exile so typical of Paris and the political research on it, shifting to an almost overwhelming culturalism: culture transfer and international comparison are the key words, and even a "spatial turn in the cultural and social sciences" is spoken of. Of course, if such perspectives have to be limited to the years before 1939, then their contrast to the constricted war years is all the more palpable, since after all the research on this has shown how zealously the system of internment camps was constructed after 1940 in both occupied and unoccupied France and how effectively the Eastern European death camps were "supplied" from here.

This moves the fate of the Jewish refugees into the centre of attention once again and shows the close relationship between exile research and Holocaust research. Another question can only be mentioned here because its disputation opens up a completely new perspective in both social and methodological terms: Whereas women's studies have long since become a vital component of exile research activities - three-quarters of the authors of the cited volume from 2002 were women - one might doubt whether the focus on gender leads automatically to a re-politicization of historical exile, as the final paper by Wiebke von Bernstorff ${ }^{31}$ calls for.

Acculturation and knowledge transfer, transdisciplinarity and international comparison, hybrid formation and histoire croisée, everyday culture and the role of women - these are the key words under which exile/emigration research is currently trying to come together. Will this enable it to succeed in this renewal - or is it merely making concessions to a postmodern Zeitgeist for which the concept of culture has turned into an all-purpose weapon, the idea of actor and author are completely dissolved, and all social reality is only "text" any longer? How can the singularity of exile be prevented from disappearing in a broad historical horizon that has, however, become ungraspable in a diffuse context that may be global, but that no longer displays any structure, for example in order to distinguish culture from politics and to bring them together again with differentiation?

\section{Conclusion}

When looking back to the changing images of exile and emigration in almost half a century we certainly see an impressive accumulation of knowledge and a clearing of methods. But we must also beware of false expectations: Within the three stages of the development we tried to distinguish, there was never a strict "logic of research" in the sense of Karl Popper. ${ }^{32}$ The move from political origins to professional methods and more theoretical reflection may be seen as a kind of progress, but the achievements in the second stage should be called "paradigmatic" only in a metaphorical sense as compared to the criteria of Thomas Kuhn. ${ }^{33}$ And when the third period shows interesting new aspects in the methodological design, this counts more as a modification or amplification of previous results than as a real "revolutionary change". So, 
as a pessimistic resumée for the state of the art we could say: Exile and emigration from Hitler's Germany, as a field of scholarly study, have returned to where it was: to the periphery of public consciousness.

Does this indicate that studies on exile and emigration are no longer functioning as a critical instance for the collective memory of a nation with a burdened history, that is, as a beacon against forgetting? Is the difficult equilibrium of historical shame and actual self-confidence, which has remained crucial for the national identity of the Germans, fading away? Thirty years after the epochal break of 1989, it might be legitimate to give the term "historicization" its innocence back and thereby return to the historians their professional pride - provided, of course, that the violent experiences of the Hitler period, which without doubt include the expulsion of scholars and artists, are neither politically whitewashed nor nostalgically misinterpreted. But even more important is that this critical reflection is continued as practical self-reflection which is not stuck in history but is applied and ever renewed for actual politics.

If research is understood as a business of "pure science" then it is always in danger of succumbing to a problematic normalization, if not to a perspective of placation. In a certain way it is already misleading, when innocently combining exile and emigration in one and the same phrase, as I have done throughout this essay. Against this danger, we must realize how much pure violence and social conflict is implied in each of these words which a responsible researcher must not be allowed to steal away. This is all the more true of the actual situation of the European Union which for decades has been confronted with new waves of political refugees, if not with unprecedented pressure from irregular migration. But in this respect I feel keen enough to construe at least some optimistic parallels between scholarly work in Germany and the potential for collective learning.

I remember very well a shocking experience from 1990/1991, when, together with colleagues, I organized a harmless conference on exile in Berlin which was still in the ecstatic paroxysms of reunification ${ }^{34}$. But only a few months later, political refugees who had lost their homeland in the Yugoslavian War streamed into the country, and the German public sphere was shaken by aggressive and even murderous reactions against the Asylanten. When comparing these shameful attacks with the situation of 2015/16, that is, with a real "asylum crisis" both in terms of the numbers of refugees flowing into Central Europe and concerning their social and bureaucratic integration, the difference is clear: It was in the first place the German government that opened the borders at least for a decisive moment, and it was a majority of the German people that reacted with the Willkommenskultur, until then an unknown term. ${ }^{35}$

This does not mean, of course, that it was research on exile and emigration, as a rather limited branch of academia, which made the difference. But if Nietzsche is right that the co-existence of remembering and forgetting is a mysterious process indeed, then it might have functioned as one factor among others - for better or worse, which still has to remain undecided when looking at further developments and especially the actual outcome: Germany was 
blamed by other members of the European Union as the hyper-moralistic "champion of asylum", and in consequence most efforts for strengthening European solidarity and finding a consistent and common asylum policy failed. The movement of refugees from Maghreb and the Middle East might have slowed down - the truth is that it was rather suppressed or buried in the Mediterranean Sea, which more than anything else has severely mauled both the moral heart and the international setting of the continent.

\section{Notes}

1 Nietzsche, 1999, 248.

2 For the general interplay between culture and politics in post-war-Germany see Müller, 2003.

3 See the introductory chapter of my book: Söllner, 1996.

4 Lübbe, 1983, 329.

5 For the role of intellectuals in East-Germany see the comprehensive book by Mittenzwei, 2001.

6 For Germany see Kraushaar, 2000; for the international arena see Frei, 2008.

7 See Krohn, 1995, 16-51.

8 See Dubiel, 1978; Söllner, 1979; Wiggershaus, 1994 (first in German 1988).

9 Walter, 1972 and later Spalek and Strelka, 1976-1989.

10 Matthias, 1968.

11 Institut für Zeitgeschichte and Research Foundation for Jewish Immigration, 1980-1983.

12 Kunst und Literatur im antifaschistischen Exil 1933-1945, 1978-1981.

13 Strauss, Fischer, Hoffmann and Söllner, 1991.

14 Möller, 1984.

15 All these tendencies resulted later in the Handbuch der deutschsprachigen Emigration 1933-1945 (Krohn, von zur Mühlen, Paul, and Winckler, 1998).

16 See especially the preface of Ash and Söllner, 1996.

17 Augstein, Bracher, Broszat, Habermas, and Fest, 1987.

18 See Söllner, 1996.

19 See Krohn and von zur Mühlen, 1997.

20 Söllner, 1988.

21 Söllner, 1996, footnote 16.

22 Söllner, 2006; Söllner, 2018.

23 Voegelin's magnum opus Order and History came out in German translation between 2001 and 2005 (Voegelin, 2001-2005), whereas the German edition of Strauss' Gesammelte Schriften (Strauss, 1996-2001) had already started in 1996, but was interrupted in 2001.

24 Goldhagen, 1996.

25 Krohn, 2012.

26 See Söllner, 2012.

27 Vormeier, 1998.

28 Saint Sauveur-Henn, 2002.

29 Krohn and Winkler, 2012.

30 Roussel and Winkler, 2012, $166 \mathrm{ff}$.

31 von Bernstorff, 2012, 304ff.

32 Popper, 1959. 
33 Kuhn, 1962.

34 Later published as Ash and Söllner, 1996.

35 See my comparative analysis: Söllner, 2017, 15-28.

\section{Bibliography}

Ash, Mitchell, and Alfons Söllner, eds. 1996. Forced Migration and Scientific Change. Émigré German-Speaking Scientists and Scholars after 1933. New York: Cambridge University Press.

Augstein, Rudolf, Karl Dietrich Bracher, Martin Broszat, Jürgen Habermas, and Joachim C. Fest. 1987. "Historikerstreit". Die Dokumentation der Kontroverse um die Einzigartigkeit der nationalsozialistischen Judenvernichtung. Munich: Piper Verlag.

Dubiel, Helmut. 1978. Wissenschaftsorganisation und politische Erfahrung. Studien zur frühen Kritischen Theorie. Frankfurt: Suhrkamp.

Frei, Norbert. 2008. 1968. Jugendrevolte und globaler Protest. München: Deutscher Taschenbuchverlag.

Goldhagen, Daniel. 1996. Hitler's Willing Executioners: Ordinary Germans and the Holocaust. New York: Alfred A. Knopf.

Institut für Zeitgeschichte and Research Foundation for Jewish Immigration, ed. 1980-1983. International Biographical Dictionary of Central European Émigrés. 3 Volumes. Munich and New York: K.G. Saur.

Kraushaar, Wolfgang. 2000. 1968 als Mythos, Chiffre und Zäsur. Hamburg: Hamburger Edition.

Krohn, Claus-Dieter. 1995. "Die Entdeckung des "anderen Deutschland" in der intellektuellen Protestbewegung der 60er Jahre in der Bundesrepublik und in den Vereinigten Staaten.” Exilforschung. Ein internationales Jahrbuch 13: 16-51.

Krohn, Claus-Dieter, and Patrik von zur Mühlen, eds. 1997. Rückkehr und Aufbau nach 1945. Deutsche Remigranten im öffentlichen Leben Nachkriegsdeutschlands. Marburg: Metropolis Verlag.

Krohn, Claus-Dieter, and Lutz Winkler, eds. 2012. Exilforschungen im historischen Prozess, Munich: Edition Text+Kritik.

Krohn, Klaus-Dieter. 2012. "Exilforschung." Docupedia-Zeitgeschichte, December 20, 2012. http://docupedia.de/zg/Exilforschung/.

Krohn, Klaus-Dieter, Patrik von zur Mühlen, Gerhard Paul, and Lutz Winckler, eds. 1998. Handbuch der deutschsprachigen Emigration 1933-1945. Darmstadt: Wissenschaftliche Buchgesellschaft.

Kuhn, Thomas. 1962. The Structure of Scientific Revolution. Chicago: University of Chicago Press.

Kunst und Literatur im antifaschistischen Exil 1933-1945. 7 Bde. 1978-1981. Frankfurt: Röderberg Verlag.

Lübbe, Hermann. 1983. "Der Nationalsozialismus im politischen Bewusstsein der Gegenwart." In Deutschlands Weg in die Diktatur, edited by Martin Broszat, 329349. Berlin: Ein Protokoll.

Matthias, Erich. ed. 1968. Mit dem Gesicht nach Deutschland. Eine Dokumentation über die sozialdemokratische Emigration. Düsseldorf: Droste.

Mittenzwei, Werner. 2001. Die Intellektuellen. Literatur und Politik in Ostdeutschland von 1945 bis 2000. Leipzig: Faber.

Möller, Horst. 1984. Exodus der Kultur. Schriftsteller, Wissenschaftler, und Künstler in der Emigration nach 1933. Munich: C.H. Beck. 
Müller, Jan-Werner, ed. 2003. German Ideologies since 1945. Studies in the Political Thought and Culture of the Bonn Republic. New York: Palgrave.

Nietzsche, Friedrich. 1999. Unzeitgemäße Betrachtung: Vom Nutzen und Nachteil der Historie, Kritische Gesamtausgabe. Vol. I. München: Deutscher Taschenbuchverlag.

Popper, Karl. 1959. The Logic of Scientific Discovery. Abingdon-on-Thames: Routledge.

Roussel, Hélène, and Lutz Winkler. 2012. "Exil in Frankreich. Selbstbehauptung, Akkulturation, Exklusion - über einige Themen der Forschung." In Exilforschungen im historischen Prozess, edited by Claus-Dieter Krohn, and Lutz Winkler, 166-191. Munich: Edition Text + Kritik.

Saint Sauveur-Henn, Anne, ed. 2002. Fluchtziel Paris. Die deutschsprachige Emigration 1933-1940. Berlin: Metropol.

Söllner, Alfons. 1979. Geschichte und Herrschaft. Studien zur materialistischen Sozialwissenschaft 1929-1945. Frankfurt: Suhrkamp.

Söllner, Alfons, 1988. Peter Weiss und die Deutschen. Die Entstehung einer politischen Ästhetik wider die Verdrängung. Wiesbaden: Westdeutscher Verlag.

Söllner, Alfons. 1996. Deutsche Politikwissenschaftler in der Emigration, ihre Akkulturation und Wirkungsgeschichte samt einer Bibliographie. Wiesbaden: Westdeutscher Verlag.

Söllner, Alfons. 2006. Fluchtpunkte. Studien zur politischen Ideengeschichte des 20. Jahrhunderts. Baden-Baden: Nomos Verlag.

Söllner, Alfons. 2012. Deutsche Frankreich-Bücher aus der Zwischenkriegszeit. BadenBaden: Nomos Verlag.

Söllner, Alfons. 2017. "Die unterschätzte Krise. Deutsche Flüchtlingspolitik 1992/3 und 2015/16." Berliner Debatte Initial 4: 15-28.

Söllner, Alfons. 2018. Political Scholar. Zur Intellektuellengeschichte des 20. Jahrhunderts. Hamburg: Westdeutscher Verlag.

Spalek, John M., and Joseph Strelka, eds. 1976-1989. Deutschsprachige Exilliteratur seit 1933. 4 Volumes. New York and Bern: Francke.

Strauss, Herbert, Klaus Fischer, Christhard Hoffmann, and Alfons Söllner, eds. 1991. Die Emigration der Wissenschaften nach 1933. Disziplingeschichtliche Studien. München and New York: K.G. Saur.

Strauss, Leo. 1996-2001. Gesammelte Schriften. Vol. I, II, III. Stuttgart: Metzler Verlag.

Voegelin, Eric. 2001-2005. Ordnung und Geschichte. 10 Volumes. Munich: Wilhelm Fink Verlag.

Vormeier, Barbara. 1998. "Frankreich.” In Handbuch der deutschsprachigen Emigration 1933-1945, edited by Claus-Dieter Krohn, and Patrik von zur Mühlen, 213-250. Darmstadt: Wissenschaftliche Buchgesellschaft.

Walter, Hans-Albert. 1972. Deutsche Exilliteratur 1933-1950. 3 Volumes. Darmstadt and Stuttgart: Springer.

von Bernstorff, Wiebke. 2012. "Geschichte(n) machen: für eine Wiederaufnahme der historisch-politischen Perspektive in der Exil(literatur)- und Genderforschung." In Exilforschungen im historischen Prozess, edited by Claus-Dieter Krohn, and Lutz Winkler, 304-326. Munich: Edition Text + Kritik.

Wiggershaus, Rolf. 1994. The Frankfort School. Cambridge: MIT Press. 


\title{
6 Personal and academic narratives of exiled and displaced scholars
}

\author{
Magdalena Kmak and Mehrnoosh Farzamfar
}

\section{Introduction}

More often than other refugees, exiled scholars publicly reflect on their displacement as a condition of political or cultural significance. While some are silent about their experiences or even refuse to be called refugees or 'exiled intellectuals', ${ }^{1}$ others recognise the impact of exile, displacement, or migration experience on their academic work and thought. In this chapter, we analyse four interviews with currently displaced legal scholars in the light of a greater body of scholarship and archival materials. The primary focus of the archival materials is on scholars with a background in legal studies or legal education, who were exiled from Nazi Germany in the 1930s and 1940s.

In this chapter, we take the experience of displacement as the main point of departure. Hannah Arendt has underlined the importance of experience for scientific work:

I have always believed that, no matter how abstract our theories may sound or how consistent our arguments appear, there are incidents and stories behind them, which, at least for ourselves, contain as in a nutshell the full meaning of whatever we have to say. Thought itself [...] arises out of the actuality of incident, and incidents of living experience must remain its guideposts by which it takes its bearing if it is not to lose itself. ${ }^{2}$

Exile and displacement, for sure, create a unique living experience. Following what Hannah Arendt has discussed, the impact of exile experience on scholarly changes has been accounted for in the literature, both in the first ${ }^{3}$ and in the second generation of exile studies. ${ }^{4}$ The latter more comprehensively covers the effects of exile on the development of science and knowledge. This approach considers, for instance, the need to stop treating the transfer of knowledge under exile or displacement as one-sided or static. Instead, these conditions need to be perceived as a formative and dynamic process. ${ }^{5}$

The work of Tuori, focusing on German-Jewish scholars of Roman law in exile in the UK, shows that the experience of exile and immersion in a new academic culture contributed significantly to the development of the idea of a shared European legal culture. ${ }^{6}$ A similar impact could be seen in the work of

DOI: $10.4324 / 9781003092421-9$ 
the Institute of Social Research (the Frankfurt School) in exile in the US. ${ }^{7}$ Kerstin von Lingen shows how the exile situation offered a 'global intellectual space' that, coupled with the experience of exile, violence, and anti-Semitism, contributed to the development of the concept of crimes against humanity. ${ }^{8}$ As she writes, the exiled scholars 'were deeply affected by personal experience of persecution and aimed to find a legal solution to bring the criminals to trial'. ${ }^{9}$

Despite the different circumstances of exile and refuge faced by contemporary displaced scholars and scholars exiled in the 1930s and 1940s, as well as the differing conditions of scientific work in contemporary western academia, common threads emerge from the research materials. This common ground encompasses issues such as the conditions of displacement and experience of asylum and refuge procedures; human rights, justice, and the need to act; development of the scholar's academic career and scholarly identity; and the relationship with the scholar's home country. In addition to these common threads, precarity comes to the fore as a condition of scholars currently displaced and is often discussed in light of precarity of contemporary academic work more generally. ${ }^{10}$

Therefore, in this chapter, we strive towards a more comprehensive understanding of the experience of displaced scholars and the role of this experience in the development of legal thought. The research on intellectual change in the work of legal scholars is particularly interesting, as historically, émigré lawyers and legal scholars faced particular difficulties in finding employment. ${ }^{11}$ This happened due to the lack of resemblance between German and US legal traditions and education. Indeed, as Graham has pointed out, by the end of the 1930s, placing foreign jurists in US law schools was nearly impossible, ${ }^{12}$ and most of them faced the need to rebrand themselves or to start afresh. Such difficulties often led to scientific change and the development of new disciplines. ${ }^{13}$

This chapter focuses on the interviews conducted with four scholars in the late autumn of 2018. Three of them are legal scholars and one works with topics related to law. These scholars are currently at different European universities. Some have the support of Scholars at Risk (or similar networks), and some are at risk, but they have found scientific positions without any institutional support. During the interviews, scholars were asked to reflect on the impacts of their exile experience on the direction and focus or the result of their research. The interview questions focused on previous and current subjects of study, topics they are working on now, any changes in their research fields, research topics, or research methods after the scholars started their research at the university they are employed now, their current and future work plans, and new projects or scholarly ideas. ${ }^{14}$

In this chapter, first we discuss the theoretical questions related to the research on exile experience and experience of displacement. Then, we investigate three distinct topics, which run through both the historical and contemporary biographies. The first topic is the conditions of exile and experiences of displacement. The second topic is the development of one's academic career and scholarly identity, and the third topic is the questions of justice, human rights, and the need to act. Even though our focus is on the 
contemporary displaced scholars, the experience of the historical figures serves as the main reference point for discussion; hence, we quote some of their accounts at the beginning of each part of analysis in section three. In the final section, we conclude the discussion.

\section{Theoretical questions related to research on experience of displacement}

The impact of the conditions of displacement on scholarly work is widely recognised in exile and migration studies. ${ }^{15}$ This includes the need to work in a foreign language and within a different scholarly tradition, to accept any position offered, and consequently to abandon the prestige of one's academic position at home university. It also often involves the need to change discipline or to start a degree from scratch. In short, these circumstances have exposed the exiled scholars to new conditions of doing science, a situation that they responded to differently. In this regard, Franz L. Neumann has identified three degrees of involvement for exiled scholars in US academia, pointing out that the most difficult but at the same time the most rewarding one was the integration of old traditions into new experiences. ${ }^{16}$ The best setting for this response was a mixed environment of native and refugee scholars, where émigrés could serve as 'bridges' between the old and the new. ${ }^{17}$

It is clear, however, that the experience of exile does not automatically create the conditions to produce new ideas and knowledge. ${ }^{18}$ In fact, this knowledge production requires certain personal attributes, coupled with certain suitable legal and socio-economic conditions. Asli Vatansever highlights:

Theoretically as well as empirically in view of some specific examples, the experience of exile as well as the nomadic/exilic state of mind signifying a discursive and epistemological breakaway from the conventional modes of thinking are assumed to be enriching in terms of intellectual subjectivity. The key in this respect lies, however, in the way the individual engages with the changing parameters of his/her mode of being in the world and copes with the loss of his/her former coordinates in life. ${ }^{19}$

The approach needed could be summarised in the words of one of the interviewed displaced scholars (Scholar 3): 'I am not comfortable in my own comfort zone.' It seems, however, that the individual's relationship to pain ${ }^{20}$ and their recognition of loss and deprivation foster their creation of new ideas and identities in exile. ${ }^{21}$ To be sure, the past impact of exile and refuge on scholarly thinking is widely recognised in exile scholarship. As Alfons Söllner puts it:

If emigration is understood as breaking the social ground of doing science and as the beginning of the transfer of ideas and cultural substance, then it can be assumed that the social rooting in the new context leaves traces behind in the new scientific environment of the country of arrival - sometimes so the émigrés realize it and sometimes their influence is seen only later. ${ }^{22}$ 
Many scholars of various disciplines, such as Hannah Arendt, Paul Tillich, Franz L. Neumann, and Reinhard Bendix, have reflected on and accounted for their experiences. The task is much more difficult when scholars do not realise the impact of these experiences and do not reflect on them. This could concern those scholars (including many lawyers) who mostly remain silent about their experiences.

Tuori, however, emphasises that even for social science scholars who did process the experience openly, the assessment of what the process of exile meant to them is fraught with difficulties. ${ }^{23}$ After scrutinising the life and scholarship of the Roman law scholar Fritz Schulz, Tuori asks, 'his work shows what can be described as a textbook case of the exile process. Or does it??24 Therefore, it is clear that any change that could possibly take place in the conditions of exile or because of the exile process is complex and very hard to classify. ${ }^{25}$

For Söllner, such change is sometimes only visible in the microsphere, in the directions of scholars' personal careers ${ }^{26}$ or in schools of thought that stayed together for a longer period, such as the New School for Social Research or the Frankfurt School in New York. ${ }^{27}$ In this chapter, therefore, we limit our analysis of the experience of displacement to direct accounts by the scholars. Such task seems to be more feasible in the case of currently displaced scholars, since the interview questions could address these changes and influences in real time. It proves much more difficult in the cases of the historical figures. Even though some of their accounts exist, they are very fragmented and escape any attempt at generalisation.

The second difficulty in our analysis is the relationship between the historical and contemporary narratives. In fact, the experiences of Jewish scholars - refugee scholars from Nazi Germany - were situated, and could not be compared with the situation of contemporary scholars. Indeed, mere exercise in comparison between the positions of historical and contemporary figures would provide a distorted and superficial image. For these two reasons, the accounts of historical figures mostly serve as background or a reference point for discussing the experiences of contemporary displaced scholars and academics at risk.

As a result, the experiences and stories discussed in this chapter do not conform to a conventional or normative discourse or narrative, which, according to Livholts and Tamboukou, is expected to '(a) [be] sequential and meaningful; (b) definitely human; (c) "re-present" experience, reconstituting it, as well as expressing it; (d) display transformation or change. ${ }^{28}$ On the one hand, accounts of exile experiences by the historical figures are mostly absent or fragmented and therefore difficult to translate into a coherent story. For instance, as Rosemary Bodenheimer, the daughter and biographer of law scholars Edgar and Brigitte Bodenheimer, writes, 'Edgar's post-war silences were widely shared by people everywhere on the spectrum of guilt, shame, survival, and suffering. ${ }^{29}$ On the other hand, the silence may not only be caused by the experiences themselves, but also occur at the level of the available research materials. They could be, for instance, produced by the archival work that can leave the researcher with nothing but fragments: 'you find nothing in the Archive, but stories caught half way through the middle of things: discontinuities. ${ }^{30}$ 
At the same time, the interviews with four contemporary displaced scholars contain accounts of scholarship in the making. Even though the interviewed scholars were eager to reflect on the development of their work, the change could most likely only be seen from the perspective of time. A linear and 'complete' narrative often emerges from accounts given at the end of life. In the words of John Herz, a legal and International Relations scholar, who fled from Nazi Germany to the US:

Telling this oral history of my life has made me think of writing memoirs, once my present projects are completed. But it would not be an autobiography: I don't think that my life as such would be of sufficient interest. It would, rather, be the story of how my views about the world developed, that is, the story of the enfolding of the world view, or world views, or Weltanschauungen, of one whose life was pretty much devoted to thought, and whose experience, covering the better part of this century, was perhaps paradigmatic of what of many others who labored in this vineyard. ${ }^{31}$

For that reason, when giving the accounts of the experiences of scholars, we followed Livholts and Tamboukou, who emphasise that,

[i]n order to be able to listen to these stories it is important that narrative researchers as well as all other listeners, suspend their preconceived narrative norms and rather treat these stories as invitations to listening in new and creative ways. ${ }^{32}$

Listening to the characters 'as they enter the stage' is therefore a part of authoring. ${ }^{33}$ Of course, these listening skills cannot be disconnected from the position from which one is listening and, then, speaking. Indeed, according to Arendt, 'in order to think politically as well as philosophically, you need a position from where to speak, you need to acknowledge your involvement in the human web of relations: you are always in the world with others' ${ }^{34}$

Our analysis in this chapter constitutes such a listening exercise, in which the experience of displaced scholars or scholars at risk and the experience and positionality of the authors as female migrant legal researchers have come together and produced a particular narrative. This narrative is born out of a dialogue between two groups of scholars: historical and contemporary figures, where the biographies of historical figures oriented the interview questions. Importantly, regardless of the predominating silences amongst law scholars, most of the historical figures cited below had a background in law. Some of them, such as John Herz or Franz Neumann, had to rebrand themselves and take positions in political science or International Relations departments. ${ }^{35}$

At the same time, the issues that arose from the interviews served as an inspiration for investigating the biographies of the historical figures. In particular, the contemporary scholars were asked the questions that we could 


\section{4}

not ask the exiled scholars. The narrative produced in this chapter is an account of this interaction between these historical and contemporary figures, filtered through the authors' own positionality and experience. In particular, whereas the authors have not experienced displacement themselves, they recognise the experience of precarity brought up in the interviews as lawyers, who are migrants and researchers. Such experience is, however, not limited to displaced or migrant scholars; it is the characteristic of all modern academia $^{36}$ or life itself. ${ }^{37}$

In this chapter, we address the emotional aspects of scholarly work, contributing to a growing body of research on both migrant emotions and academic emotions, in particular emotions in legal academia. Emotions described as 'simultaneously cognitive, motivational and physiological experience' are mutually constitutive of social reality ${ }^{38}$ and are crucial for building collectives and belonging. ${ }^{39}$ They concern academic identity and belonging. The ability to relate to pain is, according to Vatansever, a way to turn a painful experience into a reconstructing one, including intellectual and academic development. ${ }^{40}$ In addition, emotions (intertwined with cognitive functions such as reasoning and rationality) are the important elements of legal research. ${ }^{41}$

\section{Experience of displacement and academic work: silences and voiced accounts in conversation}

By listening to the interviews and reading the biographies and accounts of the historical figures, we identified the three most meaningful and unifying elements. The first element is the experience and conditions in the country of exile, refuge, or residence. The second element is the development of the scholar's academic career, in particular, their scholarly identity. The third and last element is the issues related to human rights, justice, and the need to act. In this part, we will analyse these three elements.

\section{Experiences and conditions in the country of exile and refuge}

It is important to point out that legal scholars' experience of exile, both in the past and in the present, seems to be more emotional than merely academic or scholarly. In other words, the scholarly work is affected by the multifaceted positionality of the researchers and their reaction to the world. As John Herz remarked in one of the interviews with his biographers:

The world became a theatre of the absurd. Suicide would probably have been the logical next move, and I considered it from time to time. However, I was still too young for such a radical step. One thing, however, emerged: a growing interest in domestic and, above all, international politics. My complete resignation was no longer appropriate. If not from within, fascism might perhaps still be destroyed from without. To my continuing interest in theory, therefore, was added a practical interest in action. $^{42}$ 
Similarly, the impact of emotions on the experiences of the contemporary scholars is visible in the remarks of one of the interviewees, who reminds us that the fear and the shock caused by the reality of not being able to go back home any more haunts you and stays with you forever (Scholar 1). Scholars 1 and 4 use the metaphors of 'stages of grief' and 'a sense of grief', respectively, for dealing with their emotions after realising that they are no longer able to go back to their home countries. Scholar 1, first, describes not being able to go back home anymore as a 'joke', 'it is not real, it is just a phase, but later you realise that no, this is not a phase, things are real'. After noticing how real the fact that one cannot go back is, according to all the interviewees, 'a state of uncertainty about the future strikes the mind', and 'you start to feel the burden that you should do something, that one needs to change the situation in the home country'. Scholar 2 empathises on this fear and uncertainty about the future:

I really remember that shifting my mind actually, in just like [...] So, we signed the petition and then soon after Erdoğan said that I'm not gonna live like, like this, and everybody will pay for it. Like a couple of months later, I was really realising that I was getting into an exile mode in my mind.

Together with the sense of grief, the scholars have to deal with other negative emotions such as 'guilt,' 'aimlessness,' and some levels of identity crisis related to the concepts of 'home' and 'roots.' They feel guilty that they caused problems for their family members back home. In addition, they feel empty and aimless, since they cannot connect to any particular place as their 'home' and a figurative answer to the question 'where am I from?' Struggling with these feelings was a trend easily understood in the course of all the interviews, especially in the case of Scholar 2, who, in response to the question, 'What does home mean to you?' said, 'I don't know [...] this is a question that never leaves you alone. I feel guilty that I have put my family back home in trouble. The whole family is at risk.'

Notwithstanding the feelings of grief, guilt, and uncertainty in the aftermath of realising that they could not go back home, the scholars experienced a swing of emotions ranging from misery and hopelessness to a complete sense of determination and hope for the future in the country of refuge. One possible reason for this change is the scholars' expertise and being valorised in their countries of residence. As all the interviewees mentioned, at some point in their interviews, they felt a sense of 'self-value.' This feeling came out of their academic institutions recognising their achievements: 'finally, I got somewhere where my expertise and my thought is not wasted, is wanted,' said Scholar 3, who had worked as a human rights lawyer before leaving their home country.

In addition, scholars found it helpful to realise that through their academic work in their countries of refuge or new residence they could have some influences on their environment or contribute to positive changes. It seems that 
people targeted by persecution and oppression in their home countries feel that they have something better and bigger awaiting them, so they go through the path of migration in the hope of achieving something greater. Scholar 1 expressed this mixture of thoughts and emotions: 'It is not all that black - we can make changes, we can open new horizons, we can go to new lands.'

In the interviews, we came across very different attitudes towards the countries of refuge or residence, and, hence, different experiences of lives in displacement in the context of academic work. It is obvious how differently host countries have made a hospitable or hostile environment for the scholars and, based on that, how differently scholars perceive the same country of residence. While Scholar 3 praised academia in their country of residence as a very hospitable environment to grow as a scholar, Scholar 2 about the same country said, it 'is a very difficult place; white male [scholars] dominate, taking control in academia. Positions [are] for Europeans. Discrimination is still there.'

As opposed to Scholar 2, Scholar 3 appears to be very much included in the academic environment of the country of residence. They state, 'they took me under their wings,' complementing their university colleagues and appreciating the inclusiveness of the academic environment. Like Scholar 3, Scholar 1 also admits how a hospitable academic atmosphere in their respective countries of exile helped them feel included as a member of the community, which provided them with a suitable environment to grow gradually as a scholar.

Another important aspect of the conditions of exile and displacement for legal scholars in this study is the influence of the change in their legal residence status (Scholar 1). At the same time, not being able to speak the language of the country of residence and not holding the legal status of a citizen create immense obstacles for the scholars in finding suitable positions related to their fields of expertise. Scholars 2 and 4 complained how they had to spend some years on irrelevant jobs, while they were learning the language and until they could find funding to support their academic career. Additionally, Scholars 2 and 4 emphasised that not knowing the language and the lack of legal status (not being a citizen of the country of displacement or the EU) was a reason for their not getting the kind of academic positions similar to what they used to hold in their countries of origin.

The emotions felt towards the home country or in connection with displacement, ${ }^{43}$ as well as diverse experiences in the host countries and universities, raise some broader political questions. Amongst these issues, we could think of access to rights, discrimination, and othering based on gender, age, country of origin, legal status, and other issues related to and influencing migration and refugee management more broadly. These issues have been widely discussed within the field of migration studies. ${ }^{44}$ At the same time, they also reflect the discussion on the conditions of contemporary neoliberal academia. ${ }^{45}$ These experiences point to the situatedness of the experience of displacement and the role of intersectionality in the construction of social realities. ${ }^{46}$ 


\section{Academic career development: scholarship and scholarly identity}

The question of scholarly identity in displacement became one of the most interesting ones in this study. Both historical and contemporary figures have extensively discussed this question. ${ }^{47}$ However, it should be noted that depending on their legal, academic, political, or other situation, scholars grapple with this question differently. For example, for Arnold Brecht (former high-level bureaucrat in the German Chancellery and in the Prussian Government, professor of law, and one of the first members of the 'University in Exile'), ${ }^{48}$ who regularly visited Germany and was involved in anti-Nazi activities in the late 1930s, the label 'exile intellectual' was not desirable or it was even dangerous. In his response to a request to speak on a radio programme as a 'distinguished exile,' he wrote:

Allow me, however, to state frankly that I dislike to be listed in a separate group of "distinguished exiles". I have never suffered any dramatic persecution so as to deserve the specific halo of that word. I am just a German who takes a stand for a minimum program of liberty, wherever he goes. I hate the grouping of Germans in this country into exiles and others, because it falsifies my position and separates me likewise from Germans and from Americans. ${ }^{49}$

Interviewees' answers to the question on their scholarly identity in displacement ranged from preferring to see oneself as a refugee rather than an academic (Scholar 4) and not identifying oneself as being in exile (Scholars 1 and 2) to ending with reluctant admittance of one's own position as a scholar (Scholar 3). A common thread in the interviews is the impossibility of practising or teaching law in the scholars' home countries because of the political situation and the longing to do so in the country of current residence, which is often not possible or very difficult. Out of four interviewees, two pursued a doctoral degree in law after leaving their home countries, because they were not able to practice law in their countries of exile or new residence (Scholars 1 and 3). As they remarked, they would not necessarily have done a doctoral degree without practicing law if they had not left their home countries.

As a human rights activist, Scholar 3 was forced to leave their country of origin. In their home country, outside legal practice, they were involved in lobbying and advocacy for human rights. Their advocacy work had inspired them to pursue a doctoral degree with a focus on what to do when the government is gone and on how the next democratic government could deal with the existing human rights violations. However, they faced many limitations on their advocacy work including some underlying causes for human rights violations such as corruption. As a result, Scholar 3 found in Europe a place for researching human rights. However, this scholar, who started to work on fundamental and human rights issues out of both passion and life circumstances, explained that the lack of opportunity to practice law in Europe has made them 'really sad': 
My choices became limited; [it is] difficult to practice law in other countries, so academia is [the] place to go. Otherwise, I would not have become a scholar. [...] I can do more than just writing about the law. [...] I drifted towards the academy because I had to adapt very quickly. I had to do it very quickly so that was probably the only option for me at the time.

They believe that they ended up being a scholar 'by default, reluctantly', 'I don't think there is any way out. I am just going to be a scholar now.'

At the same time, despite the lack of opportunity to practice law, Scholar 3 appreciates the development of their legal research skills and the fact that they are writing and publishing and others are citing their academic work. This makes them appreciate their position as a scholar:

What I learned or benefited from is the methodology side, the methodology aspect. This is something you really emphasise here and it actually helps, and when it comes to the legal research, when it comes to shaping your argument, being in academia or if I come back to my legal practice, it will also help me. So, I've learned a lot when it comes to the issues of methodology.

In spite of this appreciation, they continue, "that is the kind of thing scholars do. So, I am wearing different hats. I can wear that hat as a scholar, an exile scholar, but I am more comfortable not wearing any hat at all.'

Scholar 1 made similar connections with regard to not being able to practice law in Europe. As a lawyer trained in a very different legal system with different understanding of law, Scholar 1 is still struggling with the concept of law. They understand why there are so many restrictions on practising law for those trained in different legal systems; yet, they connect with Scholar 3 in how this fact has limited their career choices. Notwithstanding their complaints about barriers to legal practice for exiled or refugee lawyers, Scholar 1 recalls that what displacement has offered them is removing barriers to their thinking:

Here, in Europe, I am allowed to think, to think for myself, to think on my own. This is something I'm not used to. I had so many questions as a law student back in my home country, but it was not free enough or not safe enough to ask those questions in the classes.

Scholar 1 continues:

The sense of censorship is so embedded in you that it makes a glass wall for your thoughts. Even in the free world, we are still living inside the glass of censorship, especially coming from a legal system that is very dogmatic and positivist and makes law students accept the law as it is.

Similar to other interviewees, human rights law is the field of law in which Scholar 1 finds their genuine scholarly interest. As they said, with their background and values, they could not be a black letter lawyer, 
[a]nd now, this human right has become so much part of me that even if today I go back for any reason, I don't think I would give up on that. You know the idea of working for human rights, in the field of human rights, for the betterment of the society and the system. I would not give up on that.

Similarly, Scholar 2, for whom exile and leaving home meant losing access to their research field and data, recognises a strong link between their scholarly identity and the issues at stake in their home country. Scholar 2 states,

I am working on Turkey again, but in a different way, which is also something of the biggest impact on me. I lost my field site. Big time. And so, I must, of course, rethink what I can do from where I am, what kind of data I can still collect if I want to work on Turkey.

Scholar 2 acknowledges, however, that the academic career has become less important for them since leaving their home country:

But I also saw at that time I started caring less about my academic position, because I am also seeing people are sacrificing so much already, they lost their jobs, people do whatever they can find, working in construction. I was lucky I was already out, and I could stay wherever I am and then try to be rooted a little bit more. So at least I am quite lucky, I know that.

Scholar 4, who focused extensively on the paradoxes of their academic career in the country of refuge, referred to both emotional and practical aspects of being a refugee, but recognised that these could be also rooted in the situation in the country of origin, and in a general structure of neoliberal academia. First, the scholarly identity of Scholar 4 seems to be undergirded by uncertainty and ambiguity about the law and being a lawyer, both in the country of origin and in the country of refuge. They tried to work as lawyer in their home country, they even passed the bar exam and practiced for a year, but they were not able to continue because of corruption and the climate at the local courts. In addition, after the Arab uprisings started, Scholar 4 and their colleagues at the universities were forbidden to talk about human rights. They remember that, with a group of friends, they tried to think about how they, as lawyers, could talk about the crimes committed in Syria and not get arrested, and how they could help students who were arrested.

After fleeing to Europe, Scholar 4 was happy that they could finally come back to what they loved (research), but they were also shocked by their inability to speak the language of the country of refuge, coupled with the fact that the situation in their home country affected their academic career significantly. We quote Scholar 4 extensively because they illustrate the scope of problems displaced scholars need to deal with, including the lack of language skills, inability to focus on work because of worrying about the fate of their families and friends, and the difficulty of competing with other academics: 
Yeah, getting back to what you like to do, but you feel you are not - how to say, I don't speak [the language]. If you don't speak [the language], and you are a lawyer, you couldn't ... [uh] ... compete at all. And the second problem was that my head was not really - I could not focus. I must learn the language. I must overcome what I hear every day about my family in Syria; so, I have my mother and my brother and my sister and even not having my family there, I still think about my country. I don't want to work where I feel I couldn't do it. I am working very slowly. Most of the time, I attend [the language] courses. And, this is another problem that I don't progress a lot in [the language] courses, because I don't do enough for it. And, I don't progress enough in my work, because it is research, only research, of course, I couldn't teach. I've spent, let's say, eight years of my life, since the war started, doing nothing, just living the, let's say trying to overcome the obstacles of being from a country, which is at war. Eight years is too much. Because in eight years you could publish many books, you could - not a lot, but two books, one book, ten articles, no, let us say, four articles. I couldn't do that. This is a problem, of course, I shouldn't compare, but at the same time, I should think about my future, where is it I'm going. Everybody - I mean my [boss] is encouraging me to stay in law. But, for me, I don't see myself anymore here in law.

In response to being asked, why they do not see themselves pursuing law despite having a position in academia with a relatively good working condition, Scholar 4 said that they still found it somewhat difficult to adapt:

They are trying to give us the conditions. Like to put a tree, to plant a tree in a different, to put a tree in that is not in this climate and to do everything and trying make it grow but really, this tree is not growing. The tree either is dying or trying to survive, but not really having the fruit that you would like to see and eat.

Scholar 4 stresses that the condition for academic work, or any work for that matter, is the mental wellbeing:

First of all, are you really feeling normal? Are you sleeping well? Are you thinking in a positive way and not negative? Can you separate your problems from the problems of people in the area you are coming from?

As they mention, these obstacles affect not only themselves but also others, including their spouse, who is also a scholar, 'we have to think about different issues, we forget about when that issue is ourselves.'

To be sure, these experiences could directly affect one's research project. While three out of four interviewed scholars, particularly those, who had started their academic careers 'in exile,' had the opportunity to focus on their own research topic, for Scholar 4, doing so has been very difficult. Scholar 4 has had this opportunity, but recognised the loss of time due to not being 
able to work anymore, first in Syria, and then in the country of refuge. For the reason that their lack of language skills prevented them from being fully involved in the scholarly community in the host state, they concentrated in their current research on following and commenting on the Syrian conflict. However, as they claimed, this felt like a waste of their expertise. Therefore, they are considering changing career and giving up on academia.

When it comes to scholarly identity, Scholar 4 feels more like that of a refugee than a scholar does. Scholar 4 stopped being a scholar once they left Syria. As they say,

I couldn't be scholar here anymore although I am trying. But the refuge started and everything is done to me because I am a refugee. [...] I feel like a refugee more than I feel a scholar. I do not feel I am a normal person; I am a refugee actually.

The accounts in this section point again to the precarity of displacement linked with the politics of migration and refugee protection, which play an important role in the dissolution of old identities and the creation of new ones, such as 'refugee identity. ${ }^{50}$ Often refugee identity prevails over the scholarly, especially when structural supports and labels such as 'Scholars at Risk' highlights the individual's displacement more than their scholarly work. Despite the multiple critiques and the increasing precarity of academic knowledge, western academia has provided a way for many displaced scholars to valorise their labour and to obtain a position from which they could voice their concerns and be listened to. ${ }^{51}$

\section{Human rights, justice, and the need to act}

The need to act to counter the observed and experienced human rights violations is a common thread in the lives of both the historical figures and the interviewed scholars. In many cases, this is a response to their own experiences of suddenly turning from a scholar or a lawyer into a criminal or an outlaw. Edgar Bodenheimer, who became a law professor in Salt Lake City and later in Davis, CA, USA, considered his position as 'a lawyer disbarred by a "law", [to be] both absurd and illegal.' This strongly affected the development of his theory of jurisprudence, based on natural law principles. ${ }^{52}$

For this reason, scholars have often engaged besides their intellectual and scholarly work, in political activism linked with subjects beyond their main areas of research. Therefore, their identity is shaped not only through their scholarly work, but also through linking it with efforts to bring about changes. As Franz Neumann, who became a professor of political science and law at Columbia University in the US, said:

The intellectual is (or should be) the consciousness of the society in the prevailing time of history. His task is to measure how much (or little) society practises liberty. In a sense, the intellectual is frowned upon, because the role of the consciousness is rarely comfortable, especially in politics. ${ }^{53}$ 
Similarly, as Scholar 1 explains, 'here, the question of identity comes to light. Establishing identity, getting connected to who I am or who I want to be.' On the one hand, the need to act is often linked with 'the guilt of not being able to do much.' The interviewed scholars (for instance, Scholar 2) mentioned that they often felt guilty about leaving their home countries and not being able to make any change there.' This point is visible in some research on 'migrant emotions.' ${ }^{54}$

On the other hand, some scholars are more hopeful, and, in their work, they mainly focus on developing solutions for the time when the situation changes at home. They want to be ready. As Scholar 3 explains, "even though we are in a troubled situation and things are not going as they should, who knows, maybe things will improve at home.' They are hoping to go back home to make changes. They display a strong sense of obligation towards their homes, especially towards politics.

In addition, while the interviewed scholars feel the urgency to be involved, they cannot comprehend the lack of response to the need to act in the country of refuge. As Scholar 4 notices, 'I find strange here in this country that you could talk about what you want, in a peaceful way. But nobody talks.' When asked why they think so, they answer:

Because they are busy. They are busy. Busy, busy, busy. People are really getting out in this country from the morning and getting back home in the evening. They are tired. They want to sleep. Wake up; go to work like a machine. When you have a little time to socialise, you don't want to socialise, you want to relax. And, this is the plan of politics. Makes you busy, busy, busy not to think, that they couldn't object to you. You know there are problems, but you don't have time to organise the - let's say a group of people to say we don't want that. That is a job of people who don't have a job.

Scholar 4 expressed some difficulties in understanding that people have the freedom to protest and organise and to influence their conditions of life, but they do not: 'but when you have the chance, you don't do it. We didn't have the chance and we did it and we were killed.'

These accounts are a sharp critique of contemporary academia and liberal democracy more broadly. At the same time, they highlight the need for community building and a sense of solidarity 'in order for a new form of intellectual subjectivity to arise out of imposed precarity. ${ }^{55}$

\section{Discussion}

The accounts given by the scholars here point to the crucial place of emotions, experiences, and broader scholarly positionality in their research. This not only concerns the content of their academic work, but, more importantly, the overall ability to work, to build or maintain a scholarly identity, and to create new forms of solidarity and community. Feeling included in various 
aspects of life seems to be crucial to creating sound conditions for scientific work, with a stable legal status that guarantees security, and knowledge of the language. The interviewees also stress the significance of feelings of selfefficacy and the importance of one's actions for society, in particular in one's home country. In contrast, the feeling that one's position is based on humanitarian rather than professional considerations has often been problematic. As Hannah Arendt wrote in 1943, '[i]f we are saved, we feel humiliated, and if we are helped, we feel degraded. ${ }^{56}$

In addition, the interviewees feel disadvantaged by the time wasted and their inability to compete with scholars who did not have to experience exile and a lack of academic freedom. These feelings clash with understanding their own secure position and the gratitude for the help they received. As Asli Vatansever highlights:

Whether the experience of exile ends up affecting the person in a paralyzing or empowering way, very much depends on a "de-privatization of misery". The encounter with precariousness needs to be dissociated from the highly individualised connotations of exile and conceived as a common denominator with other forms of insecurity as experienced by different segments of the reserve army of labor. ${ }^{57}$

For us the authors, perhaps the key finding of the interviews is the importance of the emotional aspect of displacement and scholarly work. In this sense, our study contributes to a growing body of academic work on migrant emotions and academic emotions, in particular, emotions in legal academia. Despite growing recognition of the important role of emotions within various aspects of legal education, research on this topic remains scarce. In legal profession, 'thinking as a lawyer' has traditionally epitomised an approach without any emotions to legal problems or questions. ${ }^{58}$ However, the existing research points to the key role of emotions, which are intertwined with some cognitive functions such as reasoning and rationality, and hence are very important not only in legal practice, but in legal research. ${ }^{59}$

What has emerged from some of the interviews is, on the one hand, the need or often difficulty to cope with the need to compete, but, on the other hand, the inability to compete due to one's own experiences (which tap into existing discussions on wellbeing in contemporary academia, with its increased emphasis on performance and research productivity). As scholars of emotions in legal academia point out, one could notice a decrease in positive emotions (love of one's subject) and an increase in negative emotions such as stress and anxiety related to the increased focus on measurable output and performance. ${ }^{60}$

To conclude, this study clearly shows the emotional labour of academia in conjunction with the personal experiences that could have a significant impact on the scholarly life. None of these could be taken away from discussions on experiences of exile in scientific work. At the same time, the experiences of displaced academics need to be situated within general political discussions on 


\section{4}

migrant and refugee management and precarity in general. There are a lot to be learned from the experiences of displaced academics who are well situated to pose a critique of contemporary societies. New forms of identities and solidarities are needed that are rooted in shared vulnerability.

\section{Acknowledgments}

The authors express their gratitude to those who gave their time to be interviewed. Special thanks go also to Iida Silfverhuth for her tremendous help with sources in German. This work is part of the Academy of Finland funded Centre of Excellence in Law, Identity and the European Narratives (funding decision numbers 312431 and 336678).

\section{Notes}

1 Arnold Brecht, Letter to Anette Bushman, June 12, 1938. Arnold Brecht papers, The German and Jewish Intellectual Émigré Collections, SUNY Albany.

2 Livholts and Tamboukou, 2015, 121.

3 See, for instance, Fermi, 1968; Heilbut, 1997; Söllner, 1996a; Söllner, 1996b; Ash and Söllner, 1996; Coser, 1984; Krohn, 1993; Greenberg, 1987.

4 Tuori, 2020; Konuk, 2005; Camurri, 2014; Rösch, 2014; Berger and De Baets, 2016.

5 Konuk, 2005, 32; Burke, 2016, 39; Vatansever, 2020.

6 Tuori, 2020.

7 Jay, 1996, 215.

8 von Lingen, 2020.

9 von Lingen, 2020.

10 Vatansever, 2020; Özdemir, Mutluer, and Özyürek, 2019.

11 Fermi, 1968, 79.

12 Graham, 2002.

13 Ash and Söllner, 1996; Rösch, 2014.

14 In order to protect the identity of the interviewed scholars, we anonymised all the interviews. The country of origin is revealed only in case of countries with a big number of refugees. The country of current residence is not revealed in any case. We did not include information on the gender of the respondents although we are aware that the experience of refuge and being a scholar at risk seems to differ between male and female academics. In addition, we did not report nor reflect on other individual factors or personal attributions affecting the scholars' perspective.

15 See, for instance, Söllner, 1996b; Ash and Söllner, 1996; Konuk, 2005; Tuori, 2020.

16 Neumann, 1961, 20.

17 Neumann, 1961, 20.

18 Söllner, $1996 \mathrm{a}, 84$.

19 Vatansever, 2020, 148.

20 Vatansever, 2020, 148.

21 Butler, 2006, 31.

22 Söllner, 1996a, 146-147. (Translation from German by Ida Silfverhuth.)

23 Tuori, 2020, 65.

24 Tuori, 2020, 75. 
25 Tuori, 2020, 75.

26 Söllner, 1996a, 86.

27 Söllner, 1996a, 92.

28 Livholts and Tamboukou, 2015, 40.

29 Livholts and Tamboukou, 2015, 119.

30 Livholts and Tamboukou, 2015, 67.

31 Remarks typed by Prof. Spalek for SUNY Albany project. John Herz papers, The German and Jewish Intellectual Émigré Collections, SUNY Albany.

32 Livholts and Tamboukou, 2015, 100-101.

33 Livholts and Tamboukou, 2015, 54.

34 Livholts and Tamboukou, 2015, 128.

35 Kmak, 2019.

36 Vatansever, 2020.

37 Butler, 2006.

38 Boccagni and Baldassar, 2015, 73-74.

39 Ahmed, 2004, 25, 39.

40 Vatansever, 2020, 148.

41 Seear, Bliss, Galowitz, and Klein, 2019.

42 Stevens, 2018, 283.

43 Boccagni and Baldassar, 2015.

44 Gozdecka and Kmak, 2018; Fiddian-Qasmiyeh, 2020; Anthias, 2020.

45 Vatansever, 2020; Özdemir et al., 2019.

46 Anthias, 2020.

47 Vatansever, 2020.

48 Friedlander, 2019.

49 Arnold Brecht, Letter to Anette Bushman, June 12, 1938. Arnold Brecht papers, The German and Jewish Intellectual Émigré Collections, SUNY Albany.

50 Kothari, 2020.

51 Many thanks to ElSayed Elsahemy for this point.

52 Bodenheimer, 2016, 29.

53 Luthardt and Söllner, 1989, 101.

54 Boccagni and Baldassar, 2015.

55 Vatansever, 2020, 137.

56 Arendt, 2007, 268

57 Vatansever, 2020, 8.

58 Seear et al., 2019, 1.

59 Seear et al., 2019, 1.

60 Jones, 2018, 450, 475.

\section{References}

Ahmed, Sara. 2004. "Collective Feelings: Or, the Impressions Left by Others." Theory, Culture \& Society 21, no. 2: 25-42.

Anthias, Floya. 2020. Translocational Belongings: Intersectional Dilemmas and Social Inequalities. Oxford and New York: Routledge.

Arendt, Hannah. 2007. "We Refugees." In The Jewish Writings, edited by Hannah Arendt, Ron H. Feldman, and Jerome Kohn, 264-274. New York: Schocken Books. Ash, Mitchell G., and Alfons Söllner. 1996. Forced Migration and Scientific Change: Émigré German-Speaking Scientists and Scholars after 1933. Cambridge: Cambridge University Press. 
Berger, Stefan, and Antoon De Baets. 2016. "Reflections on Exile Historiography." Storia della Storiografia - History of Historiography 2016, no. 1: 11-26.

Boccagni, Paolo, and Loretta Baldassar. 2015. "Emotions on the Move: Mapping the Emergent Field of Emotion and Migration." Emotion, Space and Society 16: 73-80.

Bodenheimer, Rosemary. 2016. Edgar and Brigitte: A German Jewish Passager to America. Tuscaloosa: University of Alabama Press.

Burke, Peter. 2016. "Silver Lining: On Some Intellectual Benefits of Exile." Storia Della Storiografia, Storiografia - History of Historiography 69, no. 1: 39-48.

Butler, Judith. 2006. Precarious Life: The Powers of Mourning and Violence. London: Verso.

Camurri, Renato. 2014. "The Exile Experience Reconsidered: A Comparative Perspective in European Cultural Migration during the Interwar Period." Transatlantica. Revue d'études Américaines. American Studies Journal 1. doi:10.4000/ transatlantica.6920.

Coser, Lewis A. 1984. Refugee Scholars in America: Their Impact and Their Experiences. New Haven: Yale University Press.

Fermi, Laura. 1968. Illustrious Immigrants: The Intellectual Migration From Europe 1930-1941. Chicago: The University of Chicago Press.

Fiddian-Qasmiyeh, Elena. 2020. Refuge in a Moving World: Tracing Refugee and Migrant Journeys across Disciplines. London: UCL Press.

Friedlander, Judith. 2019. A Light in Dark Times: The New School for Social Research and Its University in Exile. New York: Columbia University Press.

Gozdecka, Dorota A., and Magdalena Kmak. 2018. "Law and the Other." No Foundations: Interdisciplinary Journal of Law and Justice 15: i-ix.

Graham, Kyle. 2002. "The Refugee Jurist and American Law Schools, 1933-1941." American Journal of Comparative Law 50, no. 4: 777-818.

Greenberg, Karen J. 1987. The Mentor Within: The German Refugee Scholars of the Nazi Period and Their American Context. New Haven and London: Yale University.

Heilbut, Anthony. 1997. Exiled in Paradise: German Refugee Artists and Intellectuals in America from the 1930s to the Present. Berkeley, Los Angeles, and London: University of California Press.

Jay, Martin. 1996. The Dialectical Imagination: A History of the Frankfurt School and the Institute of Social Research, 1923-50. Berkeley: University of California Press.

Jones, Emma. 2018. "Transforming Legal Education through Emotions." Legal Studies. The Journal of the Society of Legal Scholars 38, no. 3: 450-479.

Kmak, Magdalena. 2019. "The Impact of Exile on Law and Legal Science 1934 1964." In Roman Law and The Idea of Europe, edited by Kaius Tuori, and Heta Björklund, 15-34. London: Bloomsbury.

Konuk, Kader. 2005. "Jewish-German Philologists in Turkish Exile: Leo Spitzer and Erich Auerbach." In Exile and Otherness: New Approaches to the Experience of the Nazi Refugees, edited by Alexander Stephan, 31-48. Bern: Peter Lang.

Kothari, Uma. 2020. "Colonial Imaginaries, Colonized Places." In The Routledge Handbook of Place, edited by Ares Kalandides, Uma Kothari, and Tim Edensor, 88-90. London: Routledge.

Krohn, Claus-Dieter. 1993. Intellectuals in Exile: Refugee Scholars and the New School for Social Research. Amherst: University of Massachusetts Press.

von Lingen, Kerstin. 2020. "Legal Flows: Contributions of Exiled Lawyers to the Concept of 'Crimes Against Humanity' During the Second World War." Modern Intellectual History 17, no. 2: 507-525. 
Livholts, Mona, and Maria Tamboukou. 2015. Discourse and Narrative Methods. Thousand Oaks, CA: SAGE Publications Ltd.

Luthardt, Wolfgang, and Alfons Söllner. 1989. Verfassungsstaat, Souveränität, Pluralismus - Otto Kirchheimer Zum Gedächtnis. Oplade: Westdeutscher Verlag $\mathrm{GmbH}$.

Neumann, Franz L. 1961. "The Social Sciences.” In The Cultural Migration: The European Scholar in America, edited by Franz L. Neumann, Henri Peyre, Erwin Panofsky, Wolfgang Köhler, and Paul Tillich, 4-26. New York: A. S. Barnes.

Özdemir, Seçkin, Nil Mutluer, and Esra Özyürek. 2019. "Exile and Plurality in Neoliberal Times: Turkey's Academics for Peace." Public Culture 31, no. 2: 235-259.

Rösch, Felix. 2014. Émigré Scholars and the Genesis of International Relations a European Discipline in America? London: Palgrave Macmillan.

Seear, Kate, Lisa Bliss, Paula Galowitz, and Catherine F. Klein. 2019. "Exploring the Role of Emotions in Clinical Legal Education: Inquiry and Results from an International Workshop for Legal Educators.” The Law Teacher 53, no. 4: 79-98.

Söllner, Alfons. 1996a. Deutsche Politikwissenschaftler in Der Emigration. Studien Zu Ihrer Akkulturation Und Wirkungsgeschichte. Mit Einer Bibliographie. Wiesbaden: VS Verlag für Sozialwissenschaften.

Söllner, Alfons. 1996b. "From Public Law to Political Science? The Emigration of German Scholars after 1933 and Their Influence on the Transformation of a Discipline." In Forced Migration and Scientific Change: Émigré German-Speaking Scientists and Scholars after 1933, edited by Mitchell G. Ash, and Alfons Söllner, 246-272. Cambridge: Cambridge University Press.

Stevens, Tim. 2018. "Exeunt Omnes? Survival, Pessimism and Time in the Work of John H. Herz.” Millennium Journal of International Studies 46, no. 3: 283-302.

Tuori, Kaius. 2020. Empire of Law: Nazi Germany, Exile Scholars and the Battle for the Future of Europe. Cambridge: Cambridge University Press.

Vatansever, Asl1. 2020. At the Margins of Academia: Exile, Precariousness, and Subjectivity. Leiden. Brill. 


\title{
7 Refugee scholars then and now
}

\author{
Carol Bohmer
}

\section{Introduction}

There is a significant body of research about scholars who fled Europe in the 1930s and 1940s. Less has been written, however, about scholars at risk of persecution in the current period. In many ways the factors leading to the need for flight by scholars are similar: chaos caused by civil war and unrest, persecution of those who speak out against a ruling regime and those from persecuted minorities. There are also, however, many differences in those scholars who have sought safe haven away from their conflict torn homelands then and now. This chapter will describe the situation of both groups of refugee scholars and will conclude that current refugee scholars are subject to a perfect storm of difficult conditions for both academics and immigrants, which creates a uniquely precarious situation for them. Academics generally are currently suffering the effects of years of neoliberal changes to the system, in which their jobs are in constant jeopardy, and in which many of them are part of the gig economy, without job security or benefit. ${ }^{1}$ Whilst refugee scholars are affected by these changes, they also suffer from the widespread tightening of immigration controls, which can seriously limit their ability to remain in their country of refuge. In my interviews I spoke to scholars who are having a very tough time finding a permanent job in their host country, as well as those who move from one short-term appointment to another.

The chapter will also use the plight of scholars at risk to examine the ways in which the law and policy of asylum have changed in the years since the passage of the Convention Relating to the Status of Refugees passed in 1951. This Convention, and the Protocol which expanded it in 1967, was passed in reaction to the horrors of World War Two, after the flight of those scholars who left in the 1930s and 1940s. Even though refugee scholars fit readily into the definition of the Convention, its current application makes it an inappropriate tool to benefit them.

\section{The Interviewees}

In the chapter, I use in-depth interviews with refugee scholars mostly in the UK, but also in the US and Europe as a basis for analysis of the issue. I conducted interviews during 2019 with a total of 16 refugee scholars, four in the

DOI: $10.4324 / 9781003092421-10$ 
US, eight in the UK, three in Europe and one in South Africa. ${ }^{2}$ I constructed my sample through personal contacts from my pro bono work with refugees and asylum seekers, both in the US and the UK, and through contacts with colleagues. ${ }^{3}$ The sample is, of course, not representative; such a sample would not be possible. Finding refugee scholars to interview was not easy; many refugees are reluctant to talk about their past. Assessing representativeness is also difficult because there are no general statistics about outcomes for refugee scholars, as those organisations who work with them do not keep such figures. The majority of the interviews were conducted in person, the rest on the phone, and were based on a few specific questions ${ }^{4}$ which I used to open the conversation rather than requiring answers to them all. Most of the interviewees were willing for me to use their real names; two people were not, and in those cases, I changed their names and identifying details to protect them.

\section{Refugee scholars then and now: an overview}

To begin with, it is important to clarify what I mean by the term refugee scholar. The term refugee can be a legal one, as defined in the 1951 Convention on the Status of Refugees, Article 1A(2), as someone who has a, well-founded fear of being persecuted for reasons of race, religion, nationality, membership of a particular social group or political opinion, is outside the country of his nationality and is unable or, owing to such fear, is unwilling to avail himself of the protection of that country."

Refugee is also used more broadly to mean someone who feels they have to leave their native country. There are other terms, for example, exile and émigré, which appear to be synonyms for the second definition, and the term used by CARA (Council for Assisting Refugee Academics, which works to provide academic appointments in the UK), "scholar at risk." The American counterpart of CARA, Scholars Rescue Fund, calls them "threatened and displaced scholars." The distinctions matter, because whether or not one fits into the legal definition of refugee may be important when it comes to acquiring legal status in the country to which the scholar has fled. In this chapter, I consider those that I interviewed to be refugees, though, as we shall see later in the chapter, most of them have never had that legal status officially recognised. The status of refugee is also relevant to the scholar's self-definition, which varies considerably from scholar to scholar. Here I use the word in both the legal sense and the broader sense, depending on the context. Whatever it is called, this status is usually psychologically difficult for the scholars who fled; it is rarely something that can be left behind, but is rather a central part of the person's psyche for an extended period. "What it means to be a refugee cannot be described in the simple terms of finding a job and adjusting to foreign customs. It is a way of being, constantly lingering between arrival and departure."5

\section{Scholars then and now}

The experiences of those who fled then and those who flee now are both similar and different. They were similar in that refugee scholars suffered from 
prejudice (antisemitism then; anti-Islam sentiments now) as well as suffering from a similar sense of disruption and insecurity engendered by their flight. The situation was, however, different in several ways. First the scholars then were more likely to be senior members of the profession, and therefore known to their potential hosts. ${ }^{6}$ Thus, they had a somewhat easier time both getting out and integrating into the academic community. They also arrived at a time when academic institutions were expanding rather than contracting, as is the case now. ${ }^{7}$ The focus of those working to bring scholars out is somewhat different as well. Current refugee scholars are more likely to be recent graduates or to have interrupted their studies as a result of the persecution in their home countries. The universities in the host country are therefore more concerned with helping the scholars finish that education, rather than accepting senior scholars who could add lustre to the university. ${ }^{8}$

Because many of the scholars who fled in the 1930s and 1940s were established scholars, with international reputations, they already had contacts with colleagues; some were sponsored by US and British academics. The focus on the work of those who were most successful may, however, paint an overly rosy picture of their experiences, hiding the fact that for many of them, exile meant permanent insecurity and marginalisation, just as it does today. ${ }^{9}$

Nowadays refugee academics are more likely to come from places where their universities are less well known, and the scholars are not in a position to enhance the reputation of potential host institutions. Some of them are PhD students and postdoctoral researchers, rather than established academics. Also, the academic environment was very different in the 1930s and 1940s; then university education was expanding and those who were lucky enough to get full-time positions found welcoming universities with better facilities and libraries than they were used to, as well as more responsive students. ${ }^{10}$ Now scholars who flee do so at a time when many universities are undergoing major reductions in full-time, tenure track positions, and provide a much less welcoming environment, because tertiary education has become a business. As a result, there are far fewer opportunities available to current refugee scholars. This is not to say it was all easy for scholars who fled in the 1930s and 1940s; many of them had similarly difficult experiences as those of refugee scholars today. For example, some had trouble finding full-time jobs, and wandered from place to place. ${ }^{11}$ It is interesting that, despite prejudice which clearly existed toward the refugees,

By all accounts, this absorption of German and Jewish refugee scholars after 1933 into American institutions of higher learning despite an antisemitic and anti-German atmosphere was of a durable nature: by 1947, 77 percent of scholars exiled in 1933 had obtained faculty positions. ${ }^{12}$

This may have been because most of those who found their way to the US were sponsored by other academics. Even for those who found positions, Lebow describes extensive antisemitism (compounded by anti-immigrant sentiments) which the Jewish scholars faced at US universities. ${ }^{13}$ 
There are now several organisations in different parts of Europe and the US, who work to bring scholars from countries of war or civil unrest, for humanitarian reasons. By contrast, Siegelberg describes US institutions during the 1930s and 1940s as having the goal of bringing out potential Nobel Prize winners, for the benefit of the host country. In Britain, "academics involved with CARA were motivated by humanitarian concerns and a commitment to academic freedom rather than the politics of national prestige."14

Some of the current interest in refugees and scholarship is focused on academic institutions finding ways to provide refugees with the education that their flight interrupted. ${ }^{15}$ Many refugees find it difficult to restart their education once they arrive in their host country. Language and financial problems, not knowing how the system works, can be challenging. So, universities are providing scholarships for refugee students, and organisations are finding other ways of assisting. Recently, for example, there was a conference in Edinburgh on long-term approaches of higher education to supporting refugees and atrisk scholars. ${ }^{16}$ One NGO, RefuAid, works with universities to offer advanced English training to refugees so they can study at UK universities. A German professor of finance has set up a website to help refugee academics find jobs. ${ }^{17}$

\section{Safe haven just for now or forever?}

One of the most difficult issues for refugee scholars (and indeed for all refugees) is when and whether it is possible to return home. The refugee scholars of the 1930s and 1940s were in the US for the duration of the war, though many of them never returned. After the war, almost all of the French who left Europe for the US went back to France, including the entire French contingent at the New School, but virtually none of the other refugee scholars returned..$^{18}$ Only a very few Germans in the US went back; one went back to Frankfurt to rebuild and democratise his university department, but the others, most of whom were Jewish, stayed in the US, perhaps out of an unwillingness to trust the post-war regime's attitudes to Jews. Some, however, like Hannah Arendt, refused for years to accept that their exile was permanent. ${ }^{19}$ Most of the scholars who went to the UK also stayed there.

Current refugee academics want to return home. Stephen Wordsworth, Director of CARA, says "Almost all our Fellows are clear that they want to return home, when they can. For example, a number of those who left Syria because they came under attack from extremists are now considering return, but many are still unsure about how they would be received, so are waiting a little longer to see how things develop." 20

As Wordsworth makes clear, many of the current refugee scholars are waiting for changes which would make it possible for them to return. Almost every refugee I have met over many years of working with them, cherishes the hope of returning to their country, in which the problems which caused them to leave have miraculously disappeared. Over the years, as they adjust to their new life that hope loses salience and becomes a dream, a fantasy, rather than a realistic possibility. The passage of time itself makes it more and more 
difficult to return, because they have been changed by their refugee status in the new country, both as a result of the passage of time and new experiences. When asked if he would go back, Weysi, a Kurdish academic, now a German citizen, said "After all I went through it would be difficult to live in Kurdistan." Firas, a Syrian doctor who has been away from Syria for some years, also responded negatively: "Never. Because of the social, religious and political oppression, I would be very tied [i.e. limited]."

Refugee scholars often have a particular need or desire to return to help the country they left. Magdalene, for example, wanted to go back to Cameroon to teach nursing in the university where she studied before leaving. However, with the passage of time, and the resulting natural integration that happens over time, it becomes less likely, though the yearning may continue. Since obtaining refugee status in the US, Magdalene has married another refugee, from a different country and now has an American child, so the chances she will return are slight. Afra (not her real name), who is from Syria, told me both that she wanted to go back and that she could not go back to Syria in the same sentence, illustrating the conflict and ambivalence of being a refugee scholar.

Other refugees have no wish to go back, except perhaps for short periods, to help rebuild the country and its institutions. Firas now thinks of himself as an American, though he did say he'd be glad to return temporarily after the war ended to help rebuild. After a number of years in the US, he thinks of himself as an immigrant, rather than a refugee, although, ironically, he is one of the relatively few scholars I interviewed who is applying for asylum.

Some refugee academics still cannot return, however much they may want to. Yonas an Eritrean, who left a number of years ago, first to get a $\mathrm{PhD}$ in Sweden, then to study and work as an academic in the US, told me: "I could go back to Eritrea but the situation is unpredictable. If I went in I could go in with an ID card, I'd have to sign a paper to say I regret what I did. If they want, they can hold me."

For Mehmet, the situation is also impossible: "They wouldn't hire me in Turkey, I am probably still on the blacklist."

How painful this is for the exiled scholars varies, too, from Firas who doesn't seem at all concerned about it to Magdalene who has agonised about it. The pain for many refugees may be exacerbated by having had to leave their families behind; to the extent that other family members got out, this pain is mitigated somewhat. Taleen is now a postdoc in California; her entire family has left Iraq, either for Europe or the US (one sister lives nearby), which has helped her in adjusting to exile. The refugees who fled in the 1930s and 40s also suffered great anxiety about the fate of their families in Europe. ${ }^{21}$

After the war, the issue of return was clearer. Refugee scholars who had fled Europe in the 1930s had the choice about whether to return to their homelands or whether to stay permanently in the host country. Because many of them had permanent jobs, the choice to stay or leave was real. This choice is more complicated for refugee scholars now because of the very different nature of the visa regimes in host countries, as well as greater limits on academic jobs. In addition, the conflicts that caused some academics to flee have 
no clear ending, as did World War II, making the timing of a decision to return more fraught.

\section{The post-award trajectory of refugee scholars: temporary or permanent solution?}

It is difficult to ascertain what happens to those refugee scholars who are supported by the various agencies for a short term (usually one or two years) after their fellowship has finished. The organisations generally expect that the scholar will have developed their career and their contacts to enable them to find a job. While these organisations are happy to provide statistics about the number of scholars they assist, they do not collect information about what happens to them after the fellowship ends. ${ }^{22}$ CARA's website, for example, provides a number of profiles of the successful scholars, who have found jobs or won awards, but it is impossible to determine what percentage this represents of all those who are helped. Some of my interviewees were having difficulty finding work, and others moved from one short-term appointment to another. It is difficult to know in the absence of data how representative they are.

CARA views its mission as primarily getting people who are persecuted out of the country, as has been the case since its founding in the 1930s. As the head of the organisation said: "It is now still a rescue mission. They help people who contact them." 23 It provides a bolt hole until the academics can go home, but the problem is that for some of them that prospect is years away, if it exists at all. "We don't deal so much with 'refugee scholars' these days, if by that you mean people seeking permanent refuge, but Cara is one of the global leaders in providing temporary refuge for academics needing urgently to escape, and to find somewhere safe to continue their work until they can eventually go home again." 24

In some ways, these programs are problematic; they provide safe haven for people fleeing, but only for a short period. Then they are on their own either to return home or find a job here. Given that jobs are very hard to find, the fear of having to go back to the same situation they fled is ever present. As one author points out: "the scholars most likely to receive support are not necessarily those who are at greatest risk. Those who receive the fellowships tend to be scholars who have been educated in North American and European universities and have published extensively in the English language, or in French or German, in high-ranking journals." 25

The issue is whether welcoming refugee academics is a temporary solution so they can hide out until things improve at home, or whether it is to find a permanent home away from a country where the situation is not likely to change for a long time. It mirrors a fundamental question about the nature of asylum, as temporary or permanent, which asylum law and policy in host countries struggles with. Different receiving host countries have different approaches to this issue.

Obtaining asylum may not be a permanent solution for some refugee scholars, because many host states initially award asylum status for a 
temporary period only, which is usually made permanent after a period of years. ${ }^{26}$ Until recently, the UK routinely gave Indefinite Leave to Remain (ILR) after five years, but nowadays it is no longer automatic. ${ }^{27}$ The US is unusual in giving the successful asylum permanent residence one year after granting asylum.

In addition to the practical issues of survival and visa problems, the psychological implications of this temporary situation are profound for refugee scholars. Many of them suffer from Post Traumatic Stress Disorder (PTSD) from their experiences of persecution in their home countries before fleeing. Megan Berthold, a psychologist with many years of treating refugees, says: "Some academics who are targeted for persecution are able to secure short term visas to enable them to leave their unsafe environments and work in Universities abroad. While this affords them temporary relief and safety, the sense of safety feels precarious for many. They remain in a state of insecurity about the future, living in fear that they may have to return to their home country where their life and security may be in danger. Psychologically, such temporary status is much harder than if they were able to obtain asylum or another longer term or permanent legal status. Living under the stress associated with temporary status may also take a toll on their physical health."28

Many refugee scholars feel the pain of this temporary state. For example, Leila, from Azerbaijan, described her situation this way: "I am a nomad, moving all the time from one place to another, sometimes I have no money, so I housesit, petsit. I need a place to store things." Naif also uses the word nomad to describe this temporary life: "As for me, I still live in Austria, continuing with my work and life with academic nomadism as the main mode of being and working, as it were."

\section{Am I a refugee?: self-definitions}

There is a range of ways in which refugee scholars identify themselves. Kmak and Farzamfar discuss this for scholars exiled from Nazi Germany in the 1930s and 1940s, as well as for current refugee scholars. Some refugee academics see themselves as refugees first, while others emphasise their identity as academics. ${ }^{29}$ When I asked Weysi about his history as a refugee, he said immediately that he was not a refugee, not anymore; now he was a German citizen. Prosper, a human rights lawyer from Zimbabwe, defines himself as a refugee, even though he has a visa as an academic. However, he chose not to apply for asylum despite his self-perception as a refugee. "It is taking too long to get asylum, the process takes many years, and in the meantime, you can't leave, go to international conferences."

How long a refugee keeps their identity as a refugee is another important factor in the post-flight adjustment of refugees. In my experience, most refugees are anxious to put their past behind them and see themselves as something more than "only" a refugee. But the new identity is influenced by their experiences in the host country, and often contains elements of being a refugee. As Weysi said: "I am a refugee/activist and also an academic, I combine 
all three approaches." Firas said that he felt like an immigrant, but he also added "I feel a refugee by proxy because both of my siblings were able to get a visa to visit me, they decided to stay in the US and apply for asylum."

For some refugee academics, however, it is very hard to let go of the injustice that forced them to flee. It may be easier to put their past behind them if their academic work is unrelated to their experiences, so physical scientists are in an easier position than social scientists. Mohamed, from Egypt, whose field is maritime navigation, has difficulty letting go of the past. He had a huge lawsuit, which has lasted six years, against the university which fired him without merit, for political reasons. He is now torn between continuing to fight the authorities from abroad to get compensation and continuing his academic work in the UK. Unlike many other refugee scholars, Mohamed was not brought out by an NGO, but came on his own and obtained asylum in the UK. He has no current academic affiliation and very few contacts so starting again is very difficult. Before he can even begin to get back to research he would have to find an academic "home."

Connected to one's self-definition as a refugee or something else, are the perceptions of those around the scholars. Several of those I interviewed reported that their colleagues were ignorant of their history, or made them feel like an outsider. Mehmet said: "I'm finding it difficult to explain to people who I am." Because he feels uncomfortable with his colleagues, he spends most of his time in another city with his wife. Syrian Hassan (not his real name) was completely ignored by his colleagues for the whole time he was in their department. Similarly, Svensson discusses the implications of issues of ambivalence and belonging in the group of refugee scholars he interviewed. ${ }^{30}$

\section{The substance of scholarship: then and now}

The relationship between an academic's scholarship and their experiences as a refugee range from no connection to one in which one's experiences form the basis of one's research. For the scientists that I interviewed, there is usually no connection between their work and the fact that they fled their homeland. They see themselves as scientists who happen to be refugees, rather than "refugee scholars." Firas, who, as mentioned above, devoted his life to getting out of Syria, is now an academic doctor and even though he is in the process of applying for asylum, his refugee status has nothing to do with his work.

For those social scientists who work on the geographical area they left, the problem is a particular one: they may be both scholars and activists. Some of them complain that they are not taken seriously as academics, but are assumed to be nothing more than spokespeople for the cause that led them to flee. Naif said: "You are, as a Kurdish academic, you are perceived as being biased, politically engaged. I think this is very unfair, and in some cases, almost racist prejudice. I am dedicated to the same issues and also a very good academic."

Some refugee academics have been more successful in using their past for the benefit of their current work. Eric's scholarship focuses on diplomacy, state sovereignty, and the state of refugees, and he uses his personal 
experience as a refugee, especially the non-personhood of the refugee and the recognition of obligations. Ironically, he uses his connections with the members of the government in his home country, Burundi, to provide them with advice about policy issues.

Weysi's work is directly related to his status as a Kurdish refugee. As he says in an article he published on the subject:

My experiences, which are rooted both in my homeland and in Germany, have now become the field. I place my experience in relation to those of the Kurdish refugees I have interviewed, as an object of study. These memories of suffering transgress space and time in my life and constantly come up in my dreams, during conversations with other refugees, and in my social interactions. ${ }^{31}$

Weysi discusses the issue of academic objectivity in the context of his special position as a refugee scholar researching the area in which he has significant personal experience:

While objectivity in research should typically be valued, I argue that through bringing in my own position as a refugee researcher, I can contribute to a deeper understanding of the importance of self-reflectivity in field research and also bring a critical perspective to established discourse on the integration of recently-arrived refugees. ${ }^{32}$

For some, being a refugee may be an unwelcome constraint. Vatansever points out: "in accordance with the entrenched common practice to confine Non-Western scholars to regional studies, the Peace Academics in European exile are persistently expected to give talks, interviews, and lectures and do research on Turkey exclusively - regardless of their actual disciplines and research interests." 33

The case of Weysi illustrates the various ways in which one's refugee experience colors one's scholarship. Lebow describes a number of refugees of the 1930s whose work was generally informed by their background and as a result their scholarship benefited from their earlier experiences. ${ }^{34}$

Some refugee scholars continue to work in the area they worked on before leaving, but with varying degrees of difficulty. Afra, for example, is an economist who worked on issues in Syria and the Middle East. Her exile status constrains the work she would like to do. She said:

It is not easy to work, because I'd like to be able to work in Syria, couldn't do data in Syria. It is not easy to get funds for the Middle East, they are interested in funding Africa. I am working on my previous work, nothing new until now.

Mehmet's work is less constrained by being outside his country which is the focus of his research: 
I am still working on political economic issues in Turkey. I can do it from here. The 2001 crisis in Turkey led to the Justice and Development Party, Erdogan. ... I work with data, with theories, statistics. I am now working on Sovereign Wealth funds, interviews with officials would be good, but the system isn't very transparent anyway.

For Naif, there is no change in his scholarship: "There is no shift/change in my academic focus. I was working before my suspension on the same topics. I have been working on modern history, the constitution of Turkey, Ottoman/ Kurdistan-modern history, political parties."

Some scholars, by contrast, are forced to change the work they do as a result of their exile. In Zimbabwe, Prosper was a human rights lawyer. Now he is an academic in the Netherlands working on "corruption and human rights, connecting the two. My situation forced me to do something different. Sometimes I get frustrated, I gravitated to academics by default. I can't practice." His work is still clearly influenced by his experiences in his home country, which gave him a perspective and the experience to be able to undertake his current research.

\section{The limits of asylum}

The status of refugee was enshrined into law after World War II in the 1951 Convention Relating to the Status of Refugees. The need for protection came from recognition of the failure of countries to offer safe haven from the Holocaust. For those scholars fleeing in the 1930s and 1940s there was no official status of refugee; those who obtained visas would have received ordinary visas, because of the sponsorship of other scholars, or their universities. Özdemir et al. point out the difference between then and now:

Where the majority of exiled academics during the 1930s and 1940s were left stateless ... today's exiled scholars from Turkey often do not seek asylum in their host society and instead obtain work permits via temporary fellowships or grants. These scholars in exile do face a high risk of becoming stateless or stuck in their host country because their passports have been cancelled by the Turkish state. ${ }^{35}$

In theory, refugee scholars who have been persecuted by their governments for their work or their political opinions are perfect candidates for asylum. In practice asylum isn't much use to the current scholars trying to flee, for reasons I shall discuss below.

Asylum has its origins in international criminal law. ${ }^{36}$ It was initially intended to protect fugitives from extradition by their country of origin, when the reason for the extradition was determined to be unjust, i.e. persecution. In a world of open borders, this was the only reason a person would need the protection of asylum. Nowadays, asylum is considered to serve both a humanitarian purpose and a political one, viewing persecution as one kind 
of harm which causes someone to flee. Many scholars have recently suggested that the system is no longer fit for purpose, because so many refugees are fleeing climate change and general violence for which the Convention is inappropriate.$^{37}$ Price argues that it is the refocus from purely political concerns toward humanitarian relief which muddies the waters and makes less clear the original, true purpose of asylum..$^{38}$

Asylum law and policy has changed dramatically over the last several decades, as a result of both the refocus toward a human rights approach and also the events which precipitated the flight of large numbers of refugees to the global north. ${ }^{39}$ The breakup of the former Yugoslavia led to the flight of hundreds of thousands westwards. The fall of most communist regimes also made it possible for thousands to leave countries where exit had previously been blocked. The plight of the millions of refugees fleeing the war in Syrian and other repressive countries (e.g. Eritrea) is still being dealt with by the EU. These events have put the issue of asylum on the public agenda and led to a variety of mechanisms by governments to stem the flow of asylum seekers. ${ }^{40}$ The underlying theme of these restrictions in granting asylum is the view that asylum was never intended to be a way of shielding vast numbers of people from the problems of civil war and repressive governments. Instead it is an individual legal decision on the merits of the claim by someone who has managed to reach safety. The traditional concept of asylum was that it was a moral responsibility of liberal democracies to provide safety to those fleeing persecution and to make a judgment about the unethical behavior of the original country. ${ }^{41}$ However, nowadays, the public in those countries which have received large numbers of asylum seekers are not concerned about moral responsibility but instead about being overwhelmed by this influx as well as by the perceived security risks such arrivals present delineate several narratives about refugees in the recent crisis in Europe, one of which is the refugee as security threat. ${ }^{42}$ Racism plays its part in the current perception of refugees, as does compassion fatigue. Many of the current asylum seekers come from Africa, or from the war in Syria which has been going on long enough that people have run out of compassion for their plight, especially for those who are different and therefore hard to identify with.

Governments have responded to this change in attitude to asylum seekers by putting in place a number of restrictions to limit both the arrival of asylum seekers and their chance of being granted asylum. ${ }^{43}$ The efforts of the EU to cut off the routes to Europe by Syrians and others seeking asylum are well known. There are also a number of bilateral agreements designed to return asylum seekers either to their homelands or to third countries. The US has recently been returning asylum seekers to Mexico to await a hearing, making it much harder for them to mount a credible claim. When someone has been able to make an asylum claim, there are extensive delays in both the UK and the US, leaving the asylum seeker in limbo, unable to travel and unable, in the UK, to work. Hearing officers and judges both in the US and UK are pressed to deny as many claims as possible, generating what has become known as a "culture of disbelief." In this culture, scholars argue, 
applicants are presumed to be lying in their claims, with little effort on the part of the authorities to listen objectively to the substance of the claim. ${ }^{44}$

The refugee scholars who are the subject of this chapter are affected by the current asylum situation. Those who are brought to the UK by CARA are strongly discouraged from applying for asylum. Stephen Wordsworth argues that universities who sponsor academics would rather not have them claim asylum as it takes too long, though it may also be that they are concerned about the future of the program, if the Home Office sees short-term visas as a way of getting into the country to apply for asylum.$^{45}$ For that reason, short-term visas are used in the UK and also the US. It is certainly true that applying for asylum is an increasingly drawn-out process in both countries, often taking years before asylum is granted. In the UK, an asylum applicant is not permitted to work, whilst in the US the applicant can work after several months have elapsed from the date of the application. In both countries, the applicant has to remain in the country while the applications wends its way through the system.

As mentioned above, the real problems arise after the short-term academic position and its short-term visa have finished. Stephen Wordsworth, director of CARA, said: "There is the hope that they can go home after the time they have here. Finding a permanent job is an issue." ${ }^{46}$ This is a nice hope, but I personally have never met anyone who could go home after the expiration of their short-term, usually two-year, visa. For example, the Syrians who make up a significant proportion of those being helped by organisations such as CARA cannot go home now. Hassan, a Syrian who claimed asylum after he had been in the UK, was very clear that he could not go back: "Assad is consolidating his power but one still can't go back." When Hassan first came to the UK, he said he was discouraged by CARA from claiming asylum. When he decided he would have to claim asylum anyway, because he had no other option, the Home Office asked him why he didn't claim asylum when he first arrived, with the implication that his was not therefore a genuine claim. More than a year later, his asylum claim is still working its way slowly through the system. Meanwhile, he cannot work, nor can his wife, so he is living on the minuscule amount paid to him by the UK government, and suffering severe psychological distress. He can't look for a job outside the UK, because the Home Office has his passport and he is afraid of trying to get another one from the Syrian Embassy.

Whilst Hassan has no choice other than to apply for asylum to avoid going back to Syria, other scholars are luckier, because they have other options. Mehmet, for example, is married to a British citizen, which, at least in theory, makes his visa situation much easier. But even having the opportunity to apply for a spouse visa can limit his options: "once you apply for a spouse visa, you get $2 \frac{1}{2}$ years twice; what if I find a job in Canada? My wife's family, their health is deteriorating, so she might want to stay (in the UK)."

Leila was also lucky; she applied successfully for a Tier 1 visa (exceptional talent), which is a very difficult visa to obtain. She got very strong letters from colleagues, in support. "I didn't take it seriously. The Tier 1 visa is called the Leonardo da Vinci visa." 
Some scholars, like Leila, don't want to view themselves as asylum seekers: "it was as if I was defeated by the government, psychologically it was very difficult to accept." For others, it works the other way. Magdalene came to the US as a Fulbright scholar to get a PhD in nursing, with the goal of teaching nursing at a university. The lawyer who represented her was convinced she would get a visa in this capacity, because of a major shortage of nursing professors. Magdalene wouldn't hear of it because she needed to have her persecution in the Cameroon recognised, which she believed would come with a grant of asylum.

It is ironic that, despite the fact that refugee scholars easily fit into the asylum criteria, in practice current asylum law and policy doesn't work for them. They are forced to find another visa if they want to stay in the US or UK after the expiration of their short-term visa. If that is not possible, as is the case for Hassan, refugee scholars pay a huge professional and psychological price for having to apply for asylum.

\section{Precarity in employment and immigration: the perfect storm}

The term "precariat" has been used recently by scholars examining the results of globalisation and neoliberalism. According to this view, a class of precarious workers has replaced the traditional working class. This new class is characterised by insecurity and low pay for labour. Standing describes a variety of routes into the precariat, which includes part-time workers, temporary workers, unpaid or low-paid interns, independent contractors, and day labourers. ${ }^{47}$ All these categories are characterised by job insecurity, poor work conditions and few, if any, job protections. The term gig economy has come to represent the economic model of precarious work.

The academy has not been immune from this move towards precarious work. ${ }^{48}$ The direct cause of the increase in precarious work in academe has been the significant reduction in public spending for the support of universities, despite a significant increase in the numbers of students who are involved in tertiary education. "Between 1990 and 2010, state investment per student dropped by 26 percent, even as costs per student increased." 49

Kezar and her colleagues and others document the huge shift away from tenured and tenure track appointments to fixed-term contracts and low-paid part-time work.

Non-tenure track faculty members, now 70 per cent of the faculty within US higher education, average pay of $\$ 22,400$ for teaching eight courses, making less than most fast food workers and often with less job security and benefits than fast-food workers. ${ }^{50}$

The US is not alone in treating academics this way. A recent report on the status of academic employees in the UK include such statistics as: "Around $70 \%$ of the 49,000 researchers in the sector remain on fixed-term contracts, with many more living precariously on contracts which are nominally openended but which build in redundancy dates." ${ }^{51}$ 
Precarious employment has a variety of effects: psychological, practical and social. A recent survey by the UK University and College Union found, for example, that " $71 \%$ of respondents reported that they believed their mental health had been damaged by working on insecure contracts, while $43 \%$ reported that they believed their working conditions had damaged their physical health." 52

For refugee scholars, the implications of this movement toward precarious work has a particularly deleterious effect because it combines with insecure immigration status. We have seen the ways in which the UK and US system of immigration affects refugee academics' sense of insecurity and temporariness. Research indicates that recent migrants in general are more likely than others to be in temporary work and that official figures are likely to be an underestimate. ${ }^{53}$ As a researcher who works on the role of immigration in precarity puts it: "Precariousness can be created by putting people in a position of temporariness and status anxiety that makes it difficult for them to plan ahead. Through immigration controls, the state plays a direct role in this uncertainty." 54

In reality, many refugee scholars are not even able to take on precarious work, which is short-term in nature, on fixed contracts of hourly work, because they do not have the appropriate visa to do so. The exceptions are those who obtain asylum or, like Mehmet, who could have a visa through his wife.

The precarity of academic employment has a major effect on the post-fellowship trajectory of refugee scholars. This means that refugee scholars are competing with many thousands of academics for that shrinking percentage of jobs which are full-time, tenure track. The university employer needs to obtain a visa for the refugee scholar, and some universities would rather not undertake all the paperwork and expense involved, especially if there is another candidate for whom such effort is not necessary. Refugee academics are negatively affected by the relative shortage of such jobs as well as constrained by their immigrant status. Some refugee scholars who have the skills to do so, have simply given up trying to obtain work in academe and moved into other work; one refugee scholar I spoke to had become an accountant. Mohamed has gone into the importing business. Zizi, an Egyptian academic, who has a PhD in logistical supply and chain management, has been looking for any kind of job, including working at Starbucks.

Refugee scholars have to deal with the precarious nature of their jobs, like many young academics nowadays, flitting from one short-term job to the next (as long as their visa allows it). No sooner do they get one of these positions than they are looking for the next one, which is a job in itself. Looking for another position takes up a lot of time, and is stressful, especially for those still recovering from the persecution from which they fled. Also:

the displaced academics did not only lose their jobs and forfeit all rights to work in their home country, but the sudden and disruptive experience of exile also stripped them of their existing networks and professional seniority to a considerable extent. ${ }^{55}$ 
Some of the problems faced by refugee scholars finding employment after their short-term academic fellowships are less stark for those scholars who leave their countries of origin as students and who are educated in the host nations, because they may have more contacts to help them.

Refugee scholars are looking for employment with the added problem of visa precarity, in which they are constantly waiting for a decision on a visa, which may take a very long time. Or they are having to make immigration decisions which are tied to job options; for example, if someone applies for asylum, they cannot travel, and cannot therefore take another position in a different country without killing their chances for asylum in the host country.

Refugee scholars also have the additional problem of finding the time to work that results in publication, so they can be competitive on the job market with those who do not have such time constraints. Leila said:

They look at your publications, sitting back home I don't have a career like people here do. Back home, the foundations don't support research, so I write (on my own time). I worked 12 hours a day just for subsistence. It's a luxury to write academic articles.

This is the perfect storm. Refugee academics suffer all the problems of young, precarious academics, and also all the problems of those in visa insecurity. In both cases, the state has set the situation up to maximise the precarity. With less and less funding available to universities, more and more jobs are short-term, casual work, which affects those refugee scholars seeking work. The state has also set up an immigration system which is complicated, unfriendly and full of delay, requiring the gathering together of an array of suitable documents to prove whatever the authorities are looking for. Such a system exacerbates the feelings of precarity in those searching for stability. This affects refugee academics, who are even less able than other migrants to tolerate this psychological disruption, given their history of persecution and likely resultant PTSD.

The situation for refugee scholars of the 1930s and 1940s was easier in some ways. They arrived at a time when universities were expanding, rather than contracting as they are now. The initial visa was difficult to obtain, but more likely to be permanent, rather than the short-term visas often held by current refugee scholars. As mentioned above, they were more likely to be known quantities, with an international reputation, coming from recognised institutions, which would have made it a bit easier for them to obtain permanent academic positions. Current refugee academics have none of these advantages.

\section{Appendix}

Questions to ask Refugee Academics

1) Details of journey. Include questions about how they managed documentation. Did they have a visa, fellowship, etc. Did contacts with UK 
or other refuge country put them in danger? Did they use third-party contacts - for example get someone else to go to the consulate?

2) Details of education at home and in host country. How did their home education prepared them/or didn't, for what they do now?

3) What is the effect, if any, of their refugee status on their academic work?

4) How do they view themselves: As an academic first or a refugee first? How do (or don't) the two categories overlap?

5) Do they face a lack of understanding from their colleagues?

6) Do they plan to go back?

7) If so, how do they imagine their research? And do they have some particular purpose or goal they want to achieve in their homeland?

\section{Notes}

1 See e.g. Kezar et al., 2019; Petersen, 2020.

2 Quotes are from 14 of the interviewees.

3 See Bohmer and Shuman, 2007, 2018.

4 See Appendix.

5 Pachter, 1969-1970.

6 Lässig, 2017.

7 Lässig, 2017, 789.

8 Lässig, 2017, 783.

9 Tuori, in this volume.

10 Lebow, 2011, 549.

11 Lebow, 2011; Tuori, in this volume.

12 Özdemir, Mutluer, and Ozyürek, 2019, 240.

13 Lebow, 2011, 550-1; Pries, 2017.

14 Siegelberg, 2012, 286.

15 Wordsworth, 2019a.

16 Extending the Welcome: Long-term Approaches to Supporting Refugees and At-risk Scholars in Higher Education. 7-9 March 2019, University of Edinburgh.

17 Palca, 2019.

18 Lebow, 2011.

19 Lebow, 2011, 552.

20 Wordsworth, 2019a.

21 Lebow, 2011, 546.

22 See CARA Annual Report, 2018-19, 3.

23 Wordsworth, 2019a.

24 Wordsworth, 2019a.

25 Özdemir et al., 2019, 245.

26 Euronews, 2015.

27 UK Immigration Rules, s 339R, 2020.

28 Berthold, 2019.

29 Kmak and Farzamfar, in this volume.

30 Svensson, in this volume.

31 Dag, 2020, 63.

32 Dag, 2020, 63.

33 Vatansever, 2020.

34 Lebow, 2011. 


\section{Carol Bohmer}

35 Özdemir et al., 2019, 243.

36 Price, 2009.

37 Hathaway, 2018; Betts, 2013; McAdam, 2014.

38 Price, 2009.

39 Hathaway and Foster, 2014.

40 See Bergholm \& Toivanen in this volume for more on this situation.

41 Gibney, 2004.

42 Blitz, 2017; Bohmer and Shuman, 2018; Bergholm and Toivanen, in this volume.

43 Price, 2009.

44 See Bohmer and Shuman, 2018; Griffiths, 2012.

45 Wordsworth, 2019a.

46 Wordsworth, 2019b.

47 Standing, 2011.

48 Kezar et al., 2019; Vatansever, 2020.

49 Petersen, 2020.

50 Kezar et al., 2019, 1.

51 University and College Union, 2019.

52 University and College Union, 2019, 3.

53 Jayaweera and Anderson, 2008.

54 Anderson, 2013, 91.

55 Vatansever, 2020, 56.

\section{References}

Anderson, Bridget. 2013. Us and Them?: The Dangerous Politics of Immigration Control. Oxford: Oxford University Press.

Berthold, Megan. 2019. Personal Email Communication, December 17, 2019.

Betts, Alexander. 2013. Survival Migration: Failed Governance and the Crisis of Displacement. Ithaca and London: Cornell University Press.

Blitz, Brad. 2017. "Another Story: What Public Opinion Data Tell Us About Refugee and Humanitarian Policy." Journal on Migration and Human Security 5, no. 2: 379-400.

Bohmer, Carol, and Amy Shuman. 2007. Rejecting Refugees: Political Asylum in the 21 st Century. New York: Routledge.

Bohmer, Carol, and Amy Shuman. 2018. Political Asylum Deceptions: The Culture of Suspicion. London: Palgrave Macmillan.

CARA Annual Report. 2018-19. https://www.cara.ngo/cara-2018-19-annual-report/

Dag, Veysi. 2020. "Reflective Practice and the Contribution of Refugee-Researchers to Critical Understandings of the Refugee Integration Process." Oxford Monitor of Forced Migration 8, no. 2 (January): 62-67. Available at https://www.oxforcedmigration.com/post/reflective-practice-and-the-contribution-of-refugee-researchers.

Euronews. 2015. "Which Europeans Offer the Most Benefits to Migrants?” Euronews, September16,2015.https://www.euronews.com/2015/09/16/which-european-countriesoffer-the-most-social-benefits-to-migrants.

Gibney, Matthew J. 2004. The Ethics and Politics of Asylum. Cambridge: Cambridge University Press.

Griffiths, Melanie. 2012. "Vile Liars, and Truth distorters: Truth, Trust and the Asylum System.” Anthropology Today 28, no. 5: 8-12.

Hathaway, James C. 2018. "The Global Cop-Out on Refugees.” International Journal of Refugee Law 30, no. 4: 591-604. doi: 10.1093/ijrl/eey062. 
Hathaway, James C., and Michelle Foster. 2014. The Law of Refugee Status. Cambridge: Cambridge University Press.

Jayaweera, Hiranthi, and Bridget Anderson. 2008. "Migrant Workers and Vulnerable Employment: A Review of Existing Data." Centre of Migration Policy and Society (COMPAS). Report for the TUC Commission on Vulnerable Employment.

Kezar, Adrianna, et al. 2019. The Gig Academy: Mapping Labor in the Neoliberal University. Baltimore: Johns Hopkins University Press.

Lässig, Simone. 2017. "Strategies and Mechanisms of Scholar Rescue: The Intellectual Migration of the 1930s Reconsidered." Social Research 84, no. 4 (Winter): 769-807.

Lebow, Richard Ned. 2011. "German Jews and American Realism.” Constellations 18, no. 4: 545-566.

McAdam, Jane. 2014. “Conceptualizing ‘Crisis Migration’: A Theoretical Perspective.” In Humanitarian Crises and Migration: Causes, Consequences and Responses, edited by Susan F. Martin, Sanjula Weerasinghe, and Abbie Taylor, 28-49. London and New York: Routledge.

Özdemir, Seçkin Sertdemir, Nil Mutluer, and Esra Ozyürek. 2019. "Exile and Plurality in Neoliberal Times: Turkey's Academics for Peace." Public Culture 31, no. 2: 235-259.

Pachter, Henry. 1969-1970. “On Being an Exile.” Salamagundi 10-111 (Fall, Winter): $12-51$.

Palca, Joe. 2019. "While Others Saw Refugees, This German Professor Saw Human Potential." All Things Considered. NPR, February 9, 2017. https://www.npr.org/sections/goatsandsoda/2017/02/09/513700808/while-others-saw-refugees-thisgerman-professor-saw-human-potential.

Petersen, Charles. 2020. "Serfs of Academe.” New York Review of Books, March 12, 2020.

Price, Matthew E. 2009. Rethinking Asylum: History, Purpose and Limits. New York and Cambridge: Cambridge University Press.

Pries, Ludger. 2017. "Scientists as Forced Migrants and Refugees: What Can we Learn From the 1930s and 2010s?" Social Research 84, no. 4: 857-872.

Siegelberg, Mira L. 2012. "Scholarly Exiles.” History Workshop Journal 74 (Autumn): 283-288.

Standing, Guy. 2011. The Precariat: The New Dangerous Class. London: Bloomsbury Academic.

UK Immigration Rules, s 339R (accessed October 10, 2020). https://www.gov.uk/ guidance/immigration-rules/immigration-rules-part-11-asylum.

University and College Union. 2019. Counting the Costs of Casualisation of Higher Education. Key findings of a survey conducted by the University and College Union. Available at https://www.ucu.org.uk/media/10336/Counting-the-costs-of-casualisationin-higher-education-Jun-19/pdf/ucu_casualisation_in_HE_survey_report_Jun19.pdf.

Vatansever, Asl1. 2020. At the Margins of Academia: Exile, Precariousness, and Subjectivity. Leiden: Brill.

Wordsworth, Stephen. 2019a. Personal Email Communication, March 22, 2019.

Wordsworth, Stephen. 2019b. Lecture given at Pembroke College, Cambridge, UK, November 13, 2019. 


\title{
8 Beyond authoritarianism \\ Migration, uncertainty and a sense of belonging among public intellectuals
}

\author{
Christian Franklin Svensson
}

\section{Introduction}

Scholars, writers and artists hosted in Denmark, Finland, Norway and Sweden deal with uncertainty in a number of ways when living in exile from the regimes in their home countries. Globally, authoritarian governments are now in the majority, encompassing 92 countries and $54 \%$ of all human beings. ${ }^{1}$ However, as social movements and civil society activity throughout the world have shown, human mobility and demands for liberation seem also to be increasing, because citizens such as these interlocutors do not identify with repressive values.

Analyses of social arenas can potentially provide learning from new trends to gain an insight into what may happen in the future beyond current social structures and set boundaries. ${ }^{2}$ I wish to attempt to understand these individuals, who from their exiled position strive to create belonging while struggling for human rights. A prudent question to ask when encountering social challenge is: how do people deal with uncertainty ${ }^{33}$ I interpret this as an exploration of the interlocutors' navigations, imaginings and values in a perspective where the past, present and future are connected to create a sense of belonging, and in this case, preferably also societal change.

The interlocutors voice concern over lack of freedom of expression, while enjoying comparative security in their host countries. In this position of delegitimizing and acknowledging the fallibility of authority, topics of resistance and integrity are prevalent. When hegemony and injustice are challenged to create alternative cultural narratives and identities, at some point individuals may cross a line, from where it is not easy to return, as we see among interlocutors who have faced the consequence and fled their countries. On the other hand, they are attempting to co-create the world they want to live in, which prompts reflections on migration and community. "Another world is possible" is the attitude, where cultural resourcefulness is a celebration of imaginings of change.

A shared feature is an imagination of the world as dynamic and multicultural as opposed to the values of the regimes in their home-states, and they navigate within these pluralist spaces of identifications beyond finite social categorizations. When these interlocutors encounter new cultural and

DOI: $10.4324 / 9781003092421-11$ 
professional arenas, they identify with being at one and the same time the stranger and global residents. In addition, continually delegitimizing the home-state regimes in itself presents a significant sense of identity. They hold these complex transnational positions as a cultural necessity and as a reaction to authoritarianism. ${ }^{4}$

This chapter will begin by contextualizing the interlocutors' position and that of the regimes in their home countries. I then reflect on the methodical design of fieldwork. The next sections deal with challenges when encountering new cultural spheres in the host country, which provides not only physical security, but also uncertainty and lack of a sense of belonging when they are not fully accepted for a variety of reasons. They compensate for this by identifying with a sense of a global community comprising like-minded individuals as a need for meaningful inclusion. Finally, the interlocutors are framed as actors capable of delegitimizing the homogenous and hierarchical values of the regimes. The physical departure from their home countries transforms them from being private actors to political ones: ideally, if they publically withdraw their support, the regimes will cease to govern, because they will no longer represent legitimate power.

Because of their circumstances of being threatened by "disappearance", execution, torture and "political re-education", all the interlocutors' names are pseudonyms, and context-specific mention of their country of origin and each host institution has been removed.

\section{Context - the interlocutors and authoritarianism}

The interlocutors are hosted in the Nordic countries of Finland, Sweden, Norway and Denmark, and they are all affiliated with the facilitating organizations of Scholars at Risk (SAR), Scholar Rescue Fund (SRF) and the International Cities of Refuge Network (ICORN). Professionally, they are scholars, artists, writers and journalists, but often they occupy two or more categories at the same time: "I am a doctor [PhD], but I write a lot for independent media and free NGOs", says Lub from a country in the Middle East. The issue of categorization relates to concerns about how to view displacement and related concepts such as migration, refugee and exile, which risk labelling actors in terms of absolute roles, thereby imposing certain expectations on them, ${ }^{5}$ for instance victim/hero qualities. Specifically, the interlocutors wish to be seen neither as unwilling heroes nor as forced migrants, but rather as free agents, as Kim, a journalist from an East Asian country, explicates: "I do this work because I need to - for the people and for my family at home." She adds pragmatically, "also because this is all I know what to do."

Even though the interlocutors express great affection for their home countries, and a strong desire to return, when or if the authoritarian powers disappear, their identities are largely constituted by navigating beyond nation-state borders -those of both the host country and the home country. A few of the interlocutors have received permanent residency in one of the Nordic countries, but most live in precarity, not knowing where to go after their stay with 
the host institution. For Aaron, an associate professor, his needs are simple; he says that "the truth is that the main need is to get a job. A job that will help me reconnect with my family and life".

They have an awareness of insecurity as a basic feature, because they are unable to return unless the political climate changes or if they retract their critique. The latter is not an option, as most likely it is equivalent to lifelong persecution of themselves, friends and family, in addition to deprivation of a working life within their respective professional field. Several also express that they experience frustration when they think of those who have stayed in their home countries, either because they subscribe to the regimes' values, or simply because they have no possibility of leaving.

Uncertainty forms an integral part of their social arenas, ${ }^{6}$ which is a central theme when analysing authoritarianism and its discontents. ${ }^{7}$ Uncertainty entails plural connotations of ambivalence, unrest, indecision and confusion as a human condition. ${ }^{8}$ As a way of managing this, the interlocutors express a diversity of identifications ${ }^{9}$ entailing fluid strategies for social self-realization and societal emancipation. Their activities are constantly changing and being challenged, which allows them to navigate in flux rather than being directed by solidified notions of social arenas.

It will be redundant here to attempt to typologize each of the regimes, but some recurring characters are nevertheless identifiable. In each country, a single leader or a small group wield power with poorly defined boundaries, ${ }^{10}$ but with some predominant traits: limited political pluralism, repression of opponents and informal executive power. ${ }^{11}$ The regimes listen only to elements compatible with their own objectives, ${ }^{12}$ which enables the governments to thrive in a nativist call for nation-state homogenization ${ }^{13}$ to legitimize power concentration. These traits have the direct consequence of non-acceptance of the interlocutors' so-called "dissident" views with the potential subsequent decline of egalitarianism and human rights. ${ }^{14}$

\section{Methodical reflections}

A sense of belonging, community and commitment is the starting point for the interlocutors' conceptions of their current situation, ${ }^{15}$ and the methodical focus is on their everyday experiences and structural challenges to attempt to gain an insight into what lies behind their navigations and identifications, and how these are expressed. ${ }^{16}$

The Nordics are culturally slightly different one from another, and the fieldwork has focused on social arenas rather than geographical locations as a multi-sited empirical field. ${ }^{17}$ As a field that consists of shared social struggles, ${ }^{18}$ the interlocutors are linked by their professional relations and a cultural like-mindedness. Typically, they know each other from global networks, their home country or the host country, which methodically has facilitated connection to additional informants in a snowball effect. ${ }^{19}$

A combination of methodical approaches has, I believe, contributed to insights into perceptions of everyday practices, imaginings and social conditions. 
Twenty-five interlocutors were formally interviewed in addition to 10 coordinators affiliated with host institutions, the public sector, ICORN and SAR. Participatory observation and informal conversation provided insights into cultural views and social organization. ${ }^{20}$ I took part in numerous professional, cultural and social events as a prerequisite for interpreting the interlocutors' practices and identifications. Additionally, textual analysis and policy studies of media and governmental publications were conducted.

When doing fieldwork among one's own cultures, it will always remain a matter of doubt whether social norms and codes can ever be comprehended by the researcher, let alone the reader. ${ }^{21}$ In one sense, I have done fieldwork in my own familiar settings, as I am myself both from the Nordics and a scholar. On the other hand, I am not personally being persecuted by a regime. Moreover, fieldwork has been replete with novel sounds, working methods and language, and I have often been oblivious to cultural expressions of artists, writers and scholars from fields other than my own. This position of being "the other" 22 has then not merely been a geographical issue; rather, it has bestowed a fundamental awareness of non-knowledge of the social spaces being studied.

\section{Uncertainty when being hosted - "flexibility and a recognition of challenges is crucial"}

In their respective host country, the interlocutors have the opportunity to assert themselves beyond the confines of the regimes' politics; but for many, a sense of being different is prevalent as they experience non-inclusion in different forms.

They are much concerned with the nature of arrival and residence, which often presents a difficult and dilemma-filled topic. Several feel lonely and miss having relatives and close friends in their everyday lives. This correspondingly touches on their attitudes as to what one, as an invitee, ought to contribute with, which sometimes stands in stark contrast to the level of activity on which they are invited to participate. Furthermore, creating professional networks can be difficult and resource-consuming, which discourages some from seeking new contacts.

They are at times considered unwanted migrants despite having been invited to the host country. Murat speaks of a related situation: together with his programme coordinator from the university, he went to an office in the local municipality shortly after having just arrived in the country. While waiting on a bench, a heavily-built man approaches them and begins ranting his racist views. After the initial shock, his coordinator level-headedly tells the stranger of Murat's reason for being in the country. Murat reflects on the situation in his own words:

Suddenly this guy pops up, and afterwards she [the coordinator] comes over and apologizes to me. I said 'don't worry, it's fine'. She then told him that I am a professor who has come here to do research. And then he is suddenly extremely apologetic. His reaction is really interesting because you see the class aspect. 
While Murat is telling his story, he recollects with surprise his own detachment during the situation, but is perplexed by the apparent social legitimacy of the man's actions, not least because it takes place in a public setting. When recounting his experience, however, he is especially upset that in the end he is treated differently and better than other perceived immigrants, just because he is a scholar employed at the university.

An issue of non-inclusion is also present for Kasimir, a visual artist. Despite having lived in the host country with his wife and children for several years, he is exasperated when he reflects on the missing sense of community and ethical responsibility in the country: "It's an injustice to all. You might think or mean that we come from another country, and that you don't have these [authoritarian] issues, but you may have it yourself one day."

Aaron similarly reflects on distrust, both at his host university and outside, and that it is difficult to change people's perceptions. When I ask him about what can be done to make his life easier, he mentions as a strategy that in some instances it is better not to mention an affiliation with the facilitating organization, which in his case is Scholars at Risk. His experience is that this association can generate prejudice along the lines of not deserving to be an academic peer because of a perceived lack of professional abilities:

Well, I am very thankful to them [the host institution] for their support. It's great. But I have been thinking about being a supposed scholar at risk. The viewpoint of some is that you are not qualified enough to be in this position, which of course is completely false; of course. Because of this particular programme, there is this kind of thinking and misconception among employees.

Social imagining and mobilization can lead to a better life, but the danger is ever-present of turning desirable ideal into tragic reality. Aaron's experiences represent a theme among scholars relating to lack of a sense of belonging, even though they have the same academic titles as their local counterparts; some scholars even hold degrees from the global top-10 ranked institutions.

Social identifications mirror individual and collective dimensions of everyday practice among the interlocutors. "Identity is understood as a stronghold of security, even though the search for identity is often marked by insecurity and uncertainty", ${ }^{23}$ and their identities are unfortunately often expressed as a sense of difference, uncertainty and a lack of opportunity to participate in social, professional and cultural activities.

In this perspective, the interlocutors are a stranger in host countries. Drawing on Simmel, ${ }^{24}$ Bauman ${ }^{25}$ views the stranger as someone who is bodily present but mentally remote in the eyes of the cultural majority. The stranger is endured insofar as there is sufficient social distance. When this is not the case, however, then there is a constant and real possibility of "othering" 26 and rejection. On an optimistic note, this suggests the possibility for the stranger to become emotionally detached, and to view the majority culture from afar, but uncertainty and distrust will nevertheless ensue, because the stranger will 
then be regarded with scepticism as someone who by choice is either an insider or an outsider. Furthermore, many interlocutors feel that they are not contributing to society satisfactorily because they are not included in the local community. Özdemir, Mutluer and Özyurek ${ }^{27}$ identify similar findings, which they frame as states of exposure to a form of condescending humanitarianism, where individuals are not a part of everyday scholarly and collegial work.

All interlocutors, whether scholars, artists or writers, are assigned to a contact person, who is supposed to take heed of their well-being and to facilitate inclusive networks. A specific effort includes mentoring programmes with peers at the host institutions from the intent that it will proliferate connections with professional arenas and the labour market. Frequently, however, it seems that coordinators and mentors do not understand what their work should consist of, and therefore do not comprehend what type of knowledge and advancement is needed. Jay - a visual artist and an intermediary for other artists - mentions this problem related to a former colleague:

This particular guest felt mismatched. It's a very critical and important aspect of artist protection. A lot of cities, you know, God bless them, are interested in being part of programmes where they can assist artists, writers, journalists at risk and all of that. But at the end of the day, some end up doing a hatchet job, because they don't understand the artist; like when any random city is picked to host them.

Jay feels that there must be a greater focus on interlocutors' individual needs, and it is important to help interlocutors coordinate activities because it can be difficult to keep track of opportunities and relevant networks in new social settings. If this does not happen, their professional development is significantly hindered, she elaborates:

When it comes to the people that deal directly with the artists, they should be well-versed in understanding their issues and be sensitive to their needs, and so on. I think it's more the middle level than the managers; they are more important than the people at the top. I used to attend a lot of board meetings, and I really mixed and talked with coordinators in different cities, and I did see a bit of disconnection in some cases. There was particularly one, who felt she was completely mismatched in the city, because they couldn't cater to the kind of art that she performs.

Kasimir likewise reflects on the need for continuous training, supplied both from the host institution and from the public sector in each country:

There is a need to educate all stakeholders involved in the free cities [ICORN]; also the people in the migration office and other state institutions. Some applaud freedom of expression and speech, and they will do everything to help, but other cities don't know enough about it. They 
don't care enough to want to help. So maybe we should find a way to bring everybody's knowledge base to the same level, so that we can all understand that this is about injustice done to an actual person from an actual country.

As inclusion and collaboration are difficult for some host institutions to manage, the facilitating organizations like SAR and ICORN play an important role in preventing uncertainty, says Kasimir. It is crucial that coherent projects are generated, he adds. They can make use of their vast global network and expertise to allocate resources and address potentials locally, "because a recognition of challenges and flexibility is crucial to the programme", Jika, a journalist, reflects. She feels that for initiatives like the ICORN programme to succeed, it is necessary for them to facilitate adequate social mobilization: "These activities can be fashioned in a synergy between the desires of myself and the host community. The alternative is intense feelings of uncertainty." Considering that she and her colleagues are invited to the host country because of being personally threatened - and to a lesser degree because of their professional skills - Jika is astonished that there is not more emphasis on support and training to help succeed in future endeavours, whether in the host country or globally.

\section{Uncertain futures - "you get a recommendation, but it's not enough"}

All the interlocutors express pronounced pleasure in their work, and also a desire to progress in their respective field. For most of them, sufficient financial resources are available to participate in conferences, exhibitions, workshops and similar events. In these settings, they exchange experience and gain new knowledge from peers across the world, and attending is perceived as a necessity, closely linked to a professional future and community. The desire for relevant employment, and frequently a permanent position, presents a drive to participate in activities and social contexts, but in order to carry out their work properly, most of the interlocutors are challenged by not attaining enough future-oriented professional skills.

The interlocutors' social imagination is an expression of how they view themselves and their future in relation to others in social arenas, and to what extent their needs are fulfilled. ${ }^{28}$ Emmary expresses that she finds herself in a constant state of uncertainty because she is not able to get an appointment, either with an international organization or with her current host university. On one of the occasions when I spoke with her, she was particularly pessimistic about the future, expressing with some exasperation that now she is just waiting to see if her colleagues can do anything for her:

After a maximum of two years, you will be under stress again. I don't know where to go, especially if I cannot return to [home country]. And this is the big problem, really, that is facing all the scholars. As a scientist, I have done a lot of things during my trips around the world. Like at the 
University of Oxford where I also met people who deal with the same problems. So where should we go? You get a recommendation, but it's not enough.

Emmary appreciates the title of associate professor, and she feels that SAR have supported her considerably, but she is in her second yearly extension with no assurance of anything permanent.

Some countries' policy of only hosting for a limited space of time is tricky because, like Emmary, the interlocutors have no idea of their future circumstances beyond their present institutions of affiliation. Other findings emphasise this uncertain future as a recurring topic in similar programmes: “(..$)$ there are uncertainties around the sustainability of such temporary arrangements for the future of the artists' work and life conditions". ${ }^{29}$ Because of this stressful factor, Emmary says that she is not able to concentrate on doing her work properly, which creates a "catch-22 situation" that further puts her future career at risk.

Aaron, who is employed at another university, shares Emmary's bleak view of his prospects:

In reality, I need more time to get papers published and to achieve more academic landmarks. That would lead to the improvement of my $\mathrm{CV}$ in order to get a job. So I would suggest that we think of policies and strategies to handle these kinds of challenges that will lead to people feeling really secure.

Related challenges are found among "non-Western" research assistants based in the "global North", as they are almost entirely dependent on a significant international publication list, which can be strenuous work to achieve without formal training and peer guidance. ${ }^{30}$

Apart from the obvious hazards in the future of returning to the home country or having to apply for asylum within the regular state refugee systems, a profound uncertainty is at play, namely the consequence of downplaying, deleting and self-censoring one's work, as Jay reflects:

After one or two years a lot of the artists involved find themselves almost pushed to a point of self-censorship, because they know that: I have this temporary platform now, from where I can create awareness, but I am only guaranteed shelter for a limited time and then my situation worsens'. I find that many artists shrink during that period, because they don't want to draw attention to themselves, fearing that if they do, it will mean nothing at all anyway. They also become afraid that they can never go home.

For Jay, this is one of the worst reactions among his peers, because it is equal to quenching "the free spirit", which means that the regimes have won with no opportunity to change the future, so she feels. 
A consequence of uncertainty about the future can be suffering on a number of levels. ${ }^{31}$ Referring to Braidotti's becoming nomadic, ${ }^{32}$ Vatansever ${ }^{33}$ discusses social uncertainty in relation to reactions to precarity and nonbelonging. If the interlocutors' identifications are linked to uncertainty in the host country and institution, and if they do not imagine their future as being a part of these, then they will instead consolidate a feeling of nomadism and a sense of belonging among global communities.

\section{Belonging with a global community - "I immerse myself in the culture"}

The interlocutors' views of grand themes such as ethnicity, politics and gender are pointedly opposed to the regimes, which, in turn, plays a role in their navigation as it associates them with a sense of global belonging instead. They exist in a significant state of uncertainty, both because the possibilities of remaining in the host country are extremely limited if permanent residency is not granted, and because returning home will entail severe retribution and intensified curbs on freedom of expression. They wish to work and contribute to society locally, but when unable to find a job within their field, they are forced to move around globally depending on where opportunities occur, being trapped in an indeterminate state of nomadic struggle for survival.

This sense of community, combined with a higher raison d'être and a selfimage of autonomy, constructs imaginings of professional and social arenas, as Jay puts it:

Now, as always, I enjoy the company of other artists and writers. I know that they play a big role in my development. When I lived in [home country], you know, I met with artists, people in theatre, people in film and photography. I immerse myself in the culture and the knowledge. That's something I crave still. It's not something I have been able to replicate since I moved to Europe. So yes, I do feel that community.

When speaking with Jay at a contemporary art fair, Aaron joins the conversation and continues this train of thought:

I have this happiness when I feel that I belong to a larger community. It will give you the trust and respect you deserve as a person, mentally and professionally. As I said, I have made good friends with many colleagues around the world, and with students as well.

The interlocutors have their fair share of challenges, but due to both their skills and opinions, they experience a level of social security in the wider global community, not least when or if they are invited to a country to be able to continue their work. This sense of community is determined by their current needs and desires, and created from collective values and attitudes. ${ }^{34}$

To gain a picture of the mechanisms of their belonging, not only choice, but also chance must be taken into account, as Kasimir reflects: 
There is a whole group of global people like us. And of course there are a lot who don't share the same situation. We are writers and artists. We are fortunate, because we do not have nothing, so you are in a special situation, because you have all these capitals that are different.

Continuous socio-geographical mobility plays a substantial role for Kasimir alongside a well-developed sense of social indignation. As his present international success shows, his views and navigations are shaped from transcultural identifications, as someone who is willing to move around globally depending on where openings occur. He is quite aware of being connected to a larger network, and of the value of being able to make use of global opportunities, which presents him and colleagues with the potential privileged position of being part of a transnational elite.

A community is, of course, an essentialist and ideal-type construction, but whether one regards these global communities as imagined or not, ${ }^{35}$ the fact that they offer the interlocutors the opportunity to orientate themselves elsewhere than locally should not be underestimated. As autonomous actors, ${ }^{36}$ they are influenced by a sense of community with like-minded individuals, and therefore not delimited by the regimes in their home countries.

Apart from an awareness of the potential of their professional skills, their identifications are largely based on an appreciation of difference from the regimes. Factors such as ethnicity, nationality and language then become less prevalent for them when associating beyond a nation-state ${ }^{37}$ - both in their host and home country - and as such they are in constant flux. Their navigation and sense of global belonging is fashioned from a response to a contemporary, uncertain world of continual migrant movement ${ }^{38}$ whilst being a part of something other than nation-state hierarchies in a "(...) continual questioning from below of any attempt to establish order from above". 39

Though they seem doomed to become part of the global migration stream in predominantly precarious settings ${ }^{40}$ these particular global nomads may nevertheless be able to achieve social becoming, constructed from their cultural integrity and professional and intellectual opportunities to escape and potentially delegitimize the regimes.

\section{Delegitimizing authoritarianism - between uncertainty and a sense of belonging}

The emergence of authoritarianism can be construed as a failure of social, political and economic events. ${ }^{41}$ The United Nations addresses this predicament related to civil and political rights:

Everyone shall have the right to freedom of expression. This right shall include freedom to seek, receive and impart information and ideas of all kinds, regardless of frontiers; either orally, in writing or in print, in the form of art, or through any other media of choice. ${ }^{42}$ 
Based on experiences in their home countries, the interlocutors are well aware of unjust and oppressive mechanisms, and the need for a decent future for "the people", as Edward expresses it. Their alienation from the regimes is generated from a longing for social interaction and civil dialogue. When discussing these topics during a focus group conversation, Edward expounds on a related dialectic relation:

The people are what make a nation. Whether a government is despised or trusted, there can never be legitimate governance if there is no social intelligence among the citizens. It goes both ways: a good government needs the voice of the people, and the people must feel represented by any government. To make my country free again, this is one of the things I am fighting for.

Edward distrusts hierarchical governance in any form, he affirms. Though he lives in a state of uncertainty, where authorities can be trusted only so far, ${ }^{43}$ from his conviction that non-hierarchical societal bonds are based on mutual agreement, he may succeed in delegitimizing the regime in his home country to enable more egalitarian social arenas.

Without such imagination, it would not be possible to perceive the necessity for change. ${ }^{44}$ Mary Douglas ${ }^{45}$ refers to Bourdieu's concept of illusio as a belief that social struggles are worth fighting. Imagination, then, can form the foundations for both personal and societal change and resilience. ${ }^{46}$ Among the interlocutors, the illusion is that security and liberation can be achieved, and that an initial step in this process is to delegitimize the social order of the regimes.

What is feasible is closely linked to such imaginings, but because emancipatory alternatives most likely do not occur by themselves, ${ }^{47}$ social change also depends on conscious strategies. Processes of change and social emancipation are complex, but the potential for delegitimizing authoritarianism is inexhaustible. ${ }^{48}$ The interlocutors engage the media, fellow citizens and stakeholders by using a variegated repertoire of methods ranging from satire, theatre, and civil disobedience to public speaking and academic writing. In other words, they are "working microscopically, cooperatively, complicitly, and massively at political change from below". ${ }^{49}$ A delegitimization of the regimes is then exercised by disrupting normative practices and discourses in order to produce new cultural values, from a firm belief that it is possible to build a society worth living in.

When authoritarian configurations of power are revealed, their socially alienated ways of organizing life are delegitimized by appearing foolish and irrelevant, as Graeber ${ }^{50}$ argues. This is the result of deliberate agency and rigid efforts from a position which he believes we can and should uphold to reinforce ambitious and dynamic co-existence based on principles of selforganization and mutual aid. He states two assumptions: that another world is possible where forms of dominance such as racism, religion, sexism and ethno-nationalism do not exist, and that most people would then be better 
off. The second assumption is that it is a part of human ethical behaviour to endure struggles to oppose authoritarian systems. Nikolas Rose ${ }^{51}$ similarly identifies such delegitimizing responsiveness as an elementary standard and condition of human interaction, which accentuates the interlocutors' desire for a future defined by human values, so as not to reproduce illegitimate power structures that are not representative of the people.

Through their endeavours, they struggle to form the basis for an existence where the aim is not to take power, but to create pluralist and heterogeneous communities - at first hand in their home countries, which is the view of Syed, an author from the western Maghreb:

For me it is not important who is in government. I don't want to be part of direct rule. It's only important for me that all people, regardless of political views and ethnicity, can be a part of their own country. This is why I keep on writing and expressing my opinions. If the government in my country will not change, they will become more and more non-valid in the eyes of my fellow citizens, and also the international community, I think.

For Syed and the other intellectuals, their imaginings are rooted in a deepseated social awareness, which prompts them to respond rather than merely being victims of social patterns. ${ }^{52}$

Taylor ${ }^{53}$ sees such responses as expression of autonomy, and as a proposition for freedom not only for the individual, but also for society as a whole. Ideally - from the interlocutors' point of view - in this state of interregnum, though new structures have not yet fully emerged, the regimes are losing their legitimacy, and the authoritarian structures, which once represented social and organizational dogma in the home countries, now seem inappropriate and antediluvian.

\section{Conclusion}

We cannot predict what the future has in store for the interlocutors - the public intellectuals - but we can gain some insight into their imaginings, activity and identifications. As Erik Olin Wright ${ }^{54}$ reminds us, it may be difficult to imagine future scenarios, but what one can do is to attempt to diagnose harmful social mechanisms in order to neutralize them as much as possible. Ethnographic fieldwork by means of interviews and observation combined with document analysis has revealed a number of themes related to a complex sense of belonging.

Social identifications are not definitive, but subjected to fluid imaginings, opinions and ideologies, ${ }^{55}$ and there is rarely a sharp distinction between categorizations. The interlocutors' activity and resilience are shaped by diversity, and their sense of belonging is based on flexibility from an approach that one is able to subscribe to a variety of values simultaneously. The past, the present and the future are interconnected dimensions that provide a background for them to navigate in social arenas based on their own desires and abilities. 
Navigating in a global arena entails their privileged panorama of having been invited to a host country, and being a part of a community with likeminded individuals in both formal and informal relationships. However, there is a danger of idealizing their opportunities, because they may be hampered by rootless points of identification without even being able to return to their home countries, on account of the persecution they will encounter. Nevertheless, returning home can be a necessary and only - if somewhat unwelcome - option if permanent residency in the host country cannot be granted, or if there is no possibility for employment locally or on a global scale.

Experience of loss of professional networks, the labour market and family and friends in both the country of origin and the host country are prevalent. On an individual, social and professional level, they are dependent on support and meticulous attainment of career-oriented qualifications. In this respect, according to the interlocutors, attending events such as conferences and exhibitions is essential, and among the facilitating organizations and the host institutions, more emphasis should be placed on collaborating with each other and with the interlocutors.

A foundational mechanism for social change to take place from an awareness of oppressive conditions forms the circumstances for imaginings to transform into action. In this perspective, social change is the result of human experience and desire, for which the interlocutors are willing to risk their existence and careers in their home countries. Ideally, they are able to take advantage of their diversity of identifications and experience to develop cultural agency and social resilience. They seem to be able to navigate in these states of uncertainty, not least because of imaginings of belonging among a global community, which aligns them with a larger, constantly fluctuating world, beyond both the localism of their host countries and the authoritarian regimes in their home countries. From such an anticipative understanding, these intellectuals' navigations and activities may prove to create egalitarian conditions and novel social structures beyond the nation-state.

\section{Notes}

1 Lührmann et al., 2020.

2 Hannerz, 2016.

3 Douglas, 1987.

4 Eriksen, 2016; Benhabib, 2018; Özdemir, Mutluer, and Özyürek, 2019; SetonWatson, 2019.

5 Vatansever, 2020.

6 Bauman, 1990; Jacobsen, 2013.

7 Giddens and Pierson, 1998.

8 Cooper and Pratten, 2014.

9 Turner, 1974; Bauman, 1990; Kierans and Bell, 2017; Svensson, 2020.

10 Lührmann et al., 2020.

11 Linz, 2000.

12 Geddes, Wright, and Frantz, 2018, 137-140; Whyatt and Reitov, 2019.

13 Schmitt, 1988; Bauman, 1990. 
14 Gramsci, 1999.

15 Jackson, 1996.

16 Hastrup, 2018.

17 Marcus, 2011.

18 Bourdieu, 2016.

19 Svensson, 2017.

20 Hastrup, 2018.

21 Hannerz, 2016.

22 Comaroff and Comaroff, 2019.

23 Droogers, 2010, 148.

24 Simmel, 1971.

25 Bauman, 1990.

26 Kmak, 2018.

27 Özdemir et al., 2019.

28 Taylor, 2003.

29 Whyatt, 2018, 218.

30 Carney, 2017; Friedlander, 2019; Sukarieh and Tannock, 2019.

31 Bauman, 1990; Svensson, 2020.

32 Braidotti, 2011.

33 Vatansever, 2020.

34 Taylor, 1989; Mulhall and Swift, 1996; Svensson and Nielsen, 2020.

35 Anderson, 2006.

36 Durkheim, 1893.

37 Shafer, 1972; Rösch, 2014; Hansen, 2016.

38 Nail, 2015.

39 Critchley, 2008, 88.

40 Vatansever, 2020.

41 Arendt, 2004; Sen, 2007.

42 United Nations, 1976.

43 Giddens and Pierson, 1998.

44 Wenger-Trayner and Wenger-Trayner, 2020.

45 Douglas, 2001.

46 Svensson and Nielsen, 2020.

47 Wright, 2016.

48 Fassin, 2017; Sousa Santos, 2017; Cooper-Cunningham, 2019.

49 Scott, 2012, 16.

50 Graeber, 2020.

51 Rose, 2000.

52 Jenkins, 2014.

53 Taylor, 1989.

54 Wright, 2016.

55 Jenkins, 2014; Eriksen, 2016.

\section{Bibliography}

Anderson, Benedict. 2006. Imagined Communities: Reflections on the Origin and Spread of Nationalism. London: Verso Books.

Arendt, Hannah. 2004. The Origins of Totalitarianism. New York: Schocken Books.

Bauman, Zygmunt. 1990. "Modernity and Ambivalence." Theory, Culture \& Society 7: 143-169. 
Benhabib, Seyla. 2018. Exile, Statelessness, and Migration: Playing Chess with History from Hannah Arendt to Isaiah Berlin. Princeton: Princeton University Press.

Bourdieu, Pierre. 2016. La Distinction: Critique Sociale du Jugement. Paris: Minuit.

Braidotti, Rosi. 2011. Nomadic Theory: The Portable Rosi Braidotti. New York: Columbia University Press.

Carney, Stephen. 2017. "Geographies of Knowledge in Comparative Education or, How to Silence that Which Disturbs!” I Problemi della Pedagogia 63, no. 1: 171-189.

Comaroff, Jean, and John Comaroff. 2019. Ethnography and the Historical Imagination. London: Routledge.

Cooper, Elizabeth, and David Pratten. 2014. Ethnographies of Uncertainty from Africa. London: Palgrave Macmillan.

Cooper-Cunningham, Dean. 2019. "Drawing Fear of Difference: Race, Gender, and National Identity in Ms. Marvel Comics." Millennium: Journal of International Studies 48, no. 2: 165-197. doi:10.1177/0305829819889133.

Critchley, Simon. 2008. Infinitely Demanding: Ethics of Commitment, Politics of Resistance. London: Verso.

Douglas, Mary. 1987. How Institutions Think. London: Routledge \& Kegan Paul.

Douglas, Mary. 2001. "Dealing with Uncertainty.” Ethical Perspectives 8, no. 3: 145-155. doi:10.2143/EP.8.3.583185.

Droogers, André. 2010. "Religion, Identity and Security among Pomeranian Lutheran Migrants in Espírito Santo, Brazil (1880-2005)." In A World of Insecurity: Anthropological Perspectives on Human Security, edited by Thomas H. Eriksen, Ellen Bal, and Oscar Salemink, 148-181. London: Pluto Press.

Durkheim, Emile. 1893. The Division of Labour in Society. New York: The Free Press. Eriksen, Thomas Hylland. 2016. "Introduction: The Art of Belonging in an Overheated World." In Identity Destabilised, edited by Thomas H. Eriksen, and Elisabeth Schober, 1-19. London: Pluto.

Fassin, Didier. 2017. "The Endurance of Critique." Anthropological Theory 17, no. 1: 4-29.

Friedlander, Judith. 2019. A Light in Dark Times. The New School for Social Research and Its University in Exile. New York: Columbia University Press.

Geddes, Barbara, Joseph Wright, and Erica Frantz. 2018. How Dictatorships Work. Cambridge: Cambridge University Press.

Giddens, Anthony, and Christopher Pierson. 1998. Conversations with Anthony Giddens: Making Sense of Modernity. Stanford: Stanford University Press.

Graeber, David. 2020. "Policy for the Future of Work." In Work in the Future, edited by Robert Skidelsky, and Nan Craig, 157-173. Cham: Springer International Publishing.

Gramsci, Antonio. 1999. Selections from the Prison Notebooks, edited and translated by Quentin Hoare, and Geoffrey Nowell Smith. London: Electric Book Company.

Hannerz, Ulf. 2016. Writing Future Worlds: An Anthropologist Explores Global Scenarios. Cham: Springer.

Hansen, Lene. 2016. "Discourse Analysis, Post-Structuralism, and Foreign Policy." In Foreign Policy: Theories, Actors, Cases, edited by Steve Smith, Amelia Hadfield, and Tim Dunne, 95-110. Oxford: Oxford University Press.

Hastrup, Kirsten. 2018. "Collaborative Moments: Expanding the Anthropological Field through Cross-Disciplinary Practice.” Ethnos. Journal of Anthropology 83, no. 2: 316-334.

Jackson, Michael. 1996. Things as They Are: New Directions in Phenomenological Anthropology. Georgetown: University Press. 
Jacobsen, Michael Hviid. 2013. "From Modern Utopia to Liquid Modern AntiUtopia?” Indigo: Humanities Magazine for Young People 8: 24-49.

Jenkins, Richard. 2014. Social Identity. New York: Routledge.

Kierans, Ciara, and Kirsten Bell. 2017. "Cultivating Ambivalence: Some Methodological Considerations for Anthropology." Hau: Journal of Ethnographic Theory 7, no. 2: 23-44.

Kmak, Magdalena. 2018. "Crimmigration and Othering in the Finnish Law and Practice of Immigration Detention." No Foundations 15: 1-22.

Linz, Juan J. 2000. Totalitarian and Authoritarian Regimes. Boulder: Lynne Rienner Publishers.

Lührmann, Anna, Seraphine Maerz, Sandra Grahn, Nazifa Alizada, Lisa Gastaldi, Sebastian Hellmeier, Garry Hindle, and Staffan Lindberg. 2020. Autocratization Surges - Resistance Grows. Democracy Report 2020. Gothenburg: Varieties of Democracy Institute.

Marcus, George E. 2011. "Multi-sited Ethnography: Five or Six Things I Know About it Now." In Multi-Sited Ethnography. Problems and Possibilities in the Translocation of Research Methods, edited by Simon Coleman, and Pauline von Hellermann, 24-40. London: Routledge.

Mulhall, Stephen, and Adam Swift. 1996. Liberals and Communitarians. Oxford: Blackwell.

Nail, Thomas. 2015. The Figure of the Migrant. Stanford: Stanford University Press.

Özdemir, Seçkin S., Nil Mutluer, and Esra Özyürek. 2019. "Exile and Plurality in Neoliberal Times: Turkey's Academics for Peace.” Public Culture 31, no. 2: 235-259.

Rösch, Felix. 2014. Émigré Scholars and the Genesis of International Relations. Houndmills: Palgrave Macmillan.

Rose, Nikolas. 2000. "Community, Citizenship, and the Third Way." American Behavioral Scientist 43, no. 9: 1395-1411.

Schmitt, Carl. 1988. The Crisis of Parliamentary Democracy. Cambridge: MIT Press.

Scott, James C. 2012. Two Cheers for Anarchism Six Easy Pieces on Autonomy, Dignity, and Meaningful Work and Play. Princeton: Princeton University Press.

Sen, Amartya. 2007. "Global Inequality and Human Security." In Globalization and Politics in India, edited by Baldev Raj Nayar, 117-132. Oxford: Oxford University Press.

Seton-Watson, Hugh. 2019. Nations and States: An Enquiry into The Origins of Nations and the Politics of Nationalism. London: Routledge.

Shafer, Boyd C. 1972. Faces of Nationalism: New Realities and Old Myths. New York: Harcourt Brace.

Simmel, Georg. 1971. "The Stranger." In On Individuality and Social Forms: Selected Writings, edited by D. N. Levine, 143-149. London: University of Chicago Press.

Sousa Santos, Boaventura de. 2017. A Non-Occidentalist West?: Learned Ignorance and Ecology of Knowledge. Towards a Just Curriculum Theory. London: Routledge.

Sukarieh, Mayssoun, and Stuart Tannock. 2019. "Subcontracting Academia: Alienation, Exploitation and Disillusionment in the UK Overseas Syrian Refugee Research Industry." Antipode 51, no. 2: 664-686.

Svensson, Christian Franklin. 2017. "Ethnographic Methodology: Fieldwork Among Vulnerable Informants." Sage Research Methods. London: SAGE Publications. doi:10.4135/9781526419637

Svensson, Christian Franklin. 2020. "The Trickster of Exiled Intellectuals: Arcane Opposition to Injustice.” Anthropological Notebooks. Special issue: Anthropology of protest against the perceived injustice 26, no. 1: 111-128. 


\section{2}

Christian Franklin Svensson

Svensson, Christian Franklin, and Vibeke Bak Nielsen. 2020. "Community Work as Opposition: Tensions and Potentials in a Formalistic Welfare Context." Journal of Comparative Social Work. Special issue: Diversity and Tensions 15, no. 2: 33-55.

Taylor, Charles. 1989. Sources of the Self: The Making of Modern Identity. Cambridge: Polity Press.

Taylor, Charles. 2003. Modern Social Imaginaries. Durham: Duke University Press.

Turner, Victor W. 1974. "Liminal to Liminoid, in Play, Flow and Ritual: An Essay in Comparative Symbology.” Rice University Studies 60, no. 3: 53-92.

United Nations. 1976. International Covenant on Civil and Political Rights. Geneva: United Nations. https://www.ohchr.org/en/professionalinterest/pages/ccpr.aspx.

Vatansever, Asl1. 2020. At the Margins of Academia: Exile, Precariousness, and Subjectivity. Leiden: Brill.

Wenger-Trayner, Etienne, and Beverly Wenger-Trayner. 2020. Learning to Make a Difference: Value Creation in Social Learning Spaces. Cambridge: Cambridge University Press.

Whyatt, Sara. 2018. "Promoting the Freedom to Imagine and Create." In Reshaping Cultural Policies, edited by United Nations Educational, Scientific and Cultural Organization. 208-225. Paris: UNESCO.

Whyatt, Sara, and Ole Reitov. 2019. Protecting and Promoting Artistic Freedom. Hildesheim: UNESCO.

Wright, Erik Olin. 2016. Class, Crisis and the State. London: Verso Books. 


\section{Part III \\ Silencing and Gatekeeping Knowledges}


$\Rightarrow$ Taylor \& Francis

Taylor \& Francis Group

http://taylorandfrancis.com 


\title{
9 The silenced majority \\ Academic refugees and the vicissitudes of readaptation
}

\author{
Kaius Tuori
}

\section{Introduction}

In the expanding corpus of literature on scholarship and exile that has been published since the 1960s, there is a distinct bias towards success stories about exiles from Nazi Germany who arrived in the United States (US). Within intellectual history, these success stories follow a similar dramatic arch. In these narratives, a brilliant young scholar in one of the finest universities in Germany ends up persecuted by Nazis and flees to Britain or the US. There, they face further hardship, before their talent and perseverance prevail and they become even greater stars than before. They find a home in some of the best research universities in the US, attracting brilliant students and founding important schools of thought. Their career paths follow a U-shaped trajectory, where early promise is followed by a low point, the exile experience, finally leading to the apotheosis or redemption that success brings. In all of these narratives, the success of the protagonist is shown as unlikely and in contrast to the many others who either die in the war or in the camps or are left in obscurity. Such success stories abound even in the generally nuanced works such as Martin Jay's influential Permanent Exiles, about the German scholarly exiles in the US, or more recent massive compilations such as Zimmermann's and Beatson's Jurists Uprooted on lawyers exiled in Britain. ${ }^{1}$ Few have been talked about as much as the philosophers, social scientists and theorists of the German left, from the Frankfurt School to Hannah Arendt. Seyla Benhabib's excellent recent book Exile, Statelessness and Migration brings this issue to the fore: these were a group of very exceptional people whose names now have immediate recognition in the sciences, arts, literature and culture in general. Within this literature, the suicide of Walter Benjamin is frequently brought up, acting as a kind of martyrdom of the cultured. ${ }^{2}$

This narrative of success is important and hugely influential in the artistic, scientific and political development on both sides of the Atlantic. However, the question that is very rarely asked is: what about the others? What happened to those who were not able to learn the language, whose ideas did not generate interest in their adopted countries, whose persona was not up to the challenges? Who are the lost ones, the forgotten ones? ${ }^{3}$ 
The purpose of this chapter is to explore the vast majority of exiled scholars, those for whom the conventional standards of academic success were not fulfilled or were delayed. It seeks to unearth some of the cases of people whose scholarly career could be illustrated not with a $U$ (professional success at home followed by hardship and gradual return to success in exile) but an L (professional success followed by continuing hardship in exile), whose new career never took off, the people who did not fit into the model of the success story. While I must emphasize and reemphasize that there was no magic formula, no sine qua non of exile success, there were some traits and circumstances which made people susceptible to continued marginalization. At the same time, I want to emphasize that in no way am I suggesting that these people were failures or failed. Academia is now as it was then a pyramid scam, one in which chance and serendipity are as important as personal talent or initiative. A particular prejudice in the previous literature is to see those who left academia or concentrated on teaching as failures, neglecting the fact that their lives may have been as fulfilling and inspiring or even more so. ${ }^{4}$

The chapter explores mainly cases from the large group of refugees that left Nazi Germany after the Nazi takeover in 1933. This group included a sizable representation of academics, resulting from the dismissal of roughly one-third of German professors and the targeting of leftist and liberal writers and artists. Most of the exiles were of Jewish heritage. I use the term Jewish heritage because many were not religiously observant or who were considered Jewish by the peculiar Nazi criteria of blood purity, even though they observed some other faith. While this group is atypical in comparison to many other groups of refugees and exiles, they too were targets of hate suspicion, marginalization, racism and anti-Semitism while in exile. This focus on Jewish exiles who went to the UK and the US is typical of the works on exile scholarship, mainly for two reasons: first, that the number of scholars heading there was much larger than elsewhere, and second, that, especially in America, the resources and academic networks that were on offer were far greater. Further, while respect for the quality of German scholarship was universal, in American universities there were good chances of gaining a permanent position. ${ }^{5}$

Earlier literature on exiled scholars is not inconsiderable, but within it there are distinct groups. The first wave of studies emerged from direct contact with the exiles themselves, published in part as their memoirs or those of their students or family. These works focused on the exiles' experiences themselves or the impact that they had abroad. The second wave of scholarship could be described as the tallying of the exile, the making of comprehensive catalogues of who was who, and who went where. The third wave, which is only now being researched and published, seeks to focus on the impact of exile and the exile experience as a kind of knowledge production. ${ }^{6}$

The theoretical tools employed here are part of a discussion on trauma, coping and cultural adaptation. Studies on scholarly exile have been notorious in that they suffered from a theory deficit. In one of the rare exceptions to this deficit, Renato Camurri has noted how the earlier studies had an emphasis on two features, the acculturation paradigm and the impact paradigm, 
regarding the impact European scholars had on British and American culture. What these studies ignored was the change in the approaches of the migrants, exiles and refugees to their own position, regarding their country of origin, the place where they ended up and where they hoped to move, and the difficult definitional work that it involved regarding issues of belonging and becoming. ${ }^{7}$ Using this observation as a starting point, I seek to investigate what the "failed" exile scholar tells us of the expectations and attitudes directed towards and felt by the exiles. Harlem discusses the notion of the losing of the past self because of exile, resulting in a dissociative state. ${ }^{8}$

The notion of failure and being unsuccessful permeates scholarship, but most often as offhand remarks and general statements about loss of status and marginalization. This was the case in Heilbut's classic study from 1983: "As they moved to other countries, refugees found no market for their specialties. Lawyers became butlers, journalists became tailors, chemists became baby nurses." Of medical scholars, Weindling says that "It is all too easy to overlook the socially marginal: Certain academics came as domestic servants or gardeners, and pursued careers in fringe industrial laboratories or in general practice." 10 The notion of failure has even been added to whole fields of scholarship which failed to make an impact in the US. ${ }^{11}$ This dichotomy of success and failure equally perpetuates the notions of marketability as a sign of value and the individualization of the larger issue of precarity, a theme that links the historical and the contemporary approaches. ${ }^{12}$

What this chapter is emphatically not about is the speculative psychology of the individual. What we have are the writings of exiles themselves, their colleagues and family; based on those, we can make deductions about their condition and feelings as they are stated. The emphasis here is on the attitudes, skills and connections that an individual has or acquires and how she or he makes use of those. My examples are to a large degree cases that have come up during my studies on exiled lawyers and legal scholars, but I have attempted to include people from other fields as well. Perhaps because academic refugees were white and mostly ${ }^{13}$ from the socioeconomically privileged echelons, racism and anti-Semitism do not feature strongly in the narratives of exile, or that after the terrifying experiences in Germany, casual microaggressions and exclusions were normalized. Both in Britain and the US, anti-Semitism and anti-German attitudes were common, leading to feelings of alienation especially outside of academic surroundings. Many German refugees such as Franz Neumann even considered American racism and prejudice as being worse than that in Germany. ${ }^{14}$

Within the studies on refugee scholars, there has been much variation regarding terminology. Words such as refugee, exile, displaced, emigrant, migrant or émigré each come with connotation and background assumptions. As Camurri has noted, most studies ignore these basic issues that make the multifaceted field so problematic. These range from the conditions of the detachment and the trauma of escape to the political context, often regarding totalitarianism. It also includes the internal dynamics of exiled groups and their social spaces and the ways that certain symbols are reproduced and 
even how the experience plays out in creative expression. Finally, Camurri raises the issue of the inevitability of the successful ending in these narratives. A similar point is raised by Fleck, who notes that while "success can be reported and summarized relatively easily, this is not so for the opposite". ${ }^{15}$

What I am attempting in the following is to explore how these issues contributed to the adaptation or mis-adaptation of refugees and migrants. What I am hoping to present is the distinction between structural issues and individual coping strategies, demonstrating how the precariousness of the exiled academic both now and then is foremost a structural issue. The great unstated conclusion of all the success stories is the need for a miracle. This tendency of writing about miracles, exceptions, coincidences and kind acts of strangers masks the inherent structural cruelty of the exile's condition. Unless one was an exception, with expertise in a field that was in demand, with a suitable personality and language skills and connections, the exile was essentially doomed to a life of poverty, loneliness and hardship. ${ }^{16}$

\section{No help from friends}

A recurring feature of the success stories of exile is the presence of helpers and aids. These were individuals and organizations who helped both in the act of escape and transfer from the country of origin to the country of refuge. I have written much about these in my recent book, but it bears repeating how much these singular connections made a difference. For instance, professors of Roman law Fritz Schulz (1879-1957) and Fritz Pringsheim (18821967) were both quite old when they escaped from Germany, but they were carried along with a veritable network of former associates, students, editors and colleagues, who would organize housing, funding, publishing opportunities and other aid. Both these older men were given an incredible amount of help, which made it possible for them to continue their work. ${ }^{17}$ In both cases, it is possible to count five or six dedicated people, some of whom were in good positions such as professors at Oxford and worked tirelessly to help those in need.

What if no such friends are around or can be found? In the aforementioned cases, they were famous professors with wide international networks. What if you had no connections? If you were bad at making friends?

In individual cases it is quite hard to evaluate what the specific reasons for the loss of status were that one experienced, but many of the instances are quite dramatic. Austrian museum director and numismatist Alphons Barb (1901-1979) fled to Britain but was unable to gain academic work. He was interned on the Isle of Man, and upon release he worked at a factory in Leeds. ${ }^{18}$ Legal scholar Wilhelm Dickmann had to start his working career in America employed as a bouncer at cheap establishments. ${ }^{19}$ Microbiologist and mycologist Richard Klein (1892-1978) worked as a gardener before getting work as a microbiologist. ${ }^{20}$ There were equally positive turns in which individuals whose fortunes were down were aided by a chance occurrence. For instance, legal scholar Julius Fackenheim (1884-1970) had followed his 
son to Aberdeen but, having failed to find other employment, had been stocking shelves at a store. There, he encountered the principal of the university who provided him with a part-time job teaching comparative law. ${ }^{21}$

The turn to manual labour was not necessarily a result of lack of connections, but it could equally be a choice. Author Carl Zuckmayer (1896-1977) was frustrated by what he describes as the superficiality of American culture; after attempting to find a place in Hollywood, he purchased a farm in Vermont, before returning to Germany after the war. ${ }^{22}$ Even without knowledge of land prices, it is safe to assume that this was not an option open for the indigent.

There were, of course, numerous charitable institutions which sought to aid displaced scholars, from the British Society for the Protection of Science and Learning and the US Emergency Committee in Aid of Displaced Foreign Scholars to others. However, even their resources were stretched thin and it is obvious from the correspondence of the era that such help was frequently concentrated on the more fitting candidates, those who had adapted better to their new surroundings. Thus, Pringsheim managed to frustrate his helpers by his haughty attitude, which angered neighbours and officials alike. Consequently, his quarantine on the Isle of Man lasted much longer. ${ }^{23}$

A completely different category of failed support relates to those whose work permits and official documents never materialized. Lawyer Ernst Isay (1880-1943) fled from Germany to Brazil, but never gained a work permit there. However, he was invited to give lectures, meaning that had he lived longer, things might have improved..$^{24}$ Law professor Franz Haymann (18741947) fled to Britain, but was not allowed to work there. ${ }^{25}$ At the time of emigration, both were old.

In general, to a large degree, the notions of fitting in were dependent on the support one could rely upon. People who would use their contacts for your benefit, who would vouch for you and recommend you, were the ones who mattered. Many other things, such as need for a specific skill or the possibility to obtain permits and official qualifications, mattered a great deal, but within those boundaries the help from friends appears to be pre-eminent.

\section{Did not learn the language}

One of the key issues of adaptability is the willingness and the skill to learn new languages. For German and other European exiles in Britain and the US this posed a barrier for entry into academic society, from integration into circles or researchers, gaining employment or places of study or even being understood. This sense of understanding did not limit itself to language but extended to being identified as part of the same scholarly community. While there were exceptional circumstances, such as the German-speaking academic community that formed in New York or some specific laboratories, in general one needed to learn English. Thus, it comes as little surprise that so many of the successful migrants, such as medieval historian Ernst Kantorowicz, already had contacts and knew the language due to prior stays in England. This was possibly the reason such elderly legal exiles such as Schulz or 
Pringsheim were able to gain positions. Both had visited Britain before and published in British journals and, in the case of Schulz, even the Oxford University Press. In the same way younger scholars who migrated and entered American or British universities needed to know at least the basics to study. Thus, scholars such as Franz Neumann or David Daube would have the advantage that they simply had to learn to write good English. ${ }^{26}$

For those to whom learning languages was difficult or who did not have the networks or support, lack of language skills was not only a threshold but also a drawback that sabotaged a promising career. Philosopher Ernst Cassirer (1874-1945) ended up at Oxford, but found lecturing in English hard and tiresome. Having left Germany at an advanced age, Cassirer did not publish much during his time in England. ${ }^{27}$

One factor in learning languages was age, as ability to learn languages generally decreases with age. For example, pedagogue and philosopher Richard Honigswald (1875-1947) did not adapt to the American way of scientific thinking and did not learn English. The result was invisibility:

He was unable to speak and write English nor to accommodate himself to another type of scientific thinking in the United States. Therefore, his work in exile was produced exclusively for the German context, and he remained unpublished and unnoticed in American pedagogical circles. ${ }^{28}$

Camurri has noted that language is one of the key cultural resources of the individual and it defines the difficult relationship between the country and culture of origin and the adopted country. Here, Arendt's famous dictum about the mother tongue as a kind of surrogate motherland, the locus of surrogate belonging, is particularly apt. Language is tied in with the notion of national identity and its transformation in exile, and Camurri raises the problematic division used by Laurent Jeanpierre about the three types of exiles: the first is the patriot who defends his national identity, the permanent exile loses it, and the cosmopolitan acquires a twin sense of belonging. There, the patriots tended to return while the others would stay. ${ }^{29}$ Even though this tripartition may appear to be coarse and unanalytical, it raises an important point and in fact it is possible to a certain degree to distinguish people based on their approaches to language.

Legal scholar Gerhard Leibholz (1901-1982) was a good example of the issues relating to language and culture being compounded. He left Germany late and typical of exiles in Britain, he was unable to get a job, partly due to his poor language skills. Leibholz was also suspected of having Nazi sympathies, perhaps due to his vocal defence of German culture. ${ }^{30}$ In a similar way, Pringsheim was unpopular at Oxford because of his German patriotism, which manifested not only in a haughty sense of superiority, but also a habit of singing German songs loudly with his five sons with the windows open. ${ }^{31}$

Language skills were vital for academics to gain employment and to be understood. While some could have emigrated to the US and stayed in places with high immigrant populations where language learning was not as important, 
working in higher education became virtually impossible unless a modicum of language skill could be acquired. This meant that age differences became crucial.

\section{Did not adapt to life there}

In the literature on exiles, adaptation and assimilation are concepts that are strongly interlinked, but not coterminous. As is true now, learning the language, acclimatization to local conditions and getting to know people, acquiring an education and gaining employment were all crucial in the way that exiled scholars began to feel like home or at least did not immediately seek to return. However, the notions of becoming inherent in the language of assimilation are often seen as alternatives of choice to the diasporic long-term communities, making reading the exile narratives written often by local students problematic.

Even in adaptability, age was a factor. Old people with a senior position at home were liable to have difficulties, if only due to the status difference between what they had been accustomed to, and what they had on offer. Thus, cases such as that of Albert Einstein, who received a generous position in the US were utmost rarities. One of the famous German comparative lawyers Ernst Rabel (1874-1955) escaped to the US, but never gained a standing that would have been anything close to what he had enjoyed in Germany. As a result, he returned after the war. ${ }^{32}$ Hans Kelsen, the drafter of the Austrian constitution and still one of the more famous legal theorists in the world, found that his fame served him little in the US, where his type of legal positivism was little known and appreciated. He would eventually manage to gain a position at Berkeley, but only in the political science department. ${ }^{33}$

Gaining academic employment has always been difficult, but there were considerable differences between both fields and countries. As exile Erwin Panofski wrote in his outline of the birth of art history in the US, many German art historians were actively recruited to America. On the other hand, those who arrived with little expertise that would have been in demand, had a tougher time finding a job. A case in point is the numerous experts in German or even Roman law who were unable to find gainful employment in the US. The difference in countries is quite stark. Söllner has estimated that most of the people $(85 \%)$ he has studied were eventually appointed to professorships in the US, while only one-fifth of those who stayed in Britain did. ${ }^{34}$

While younger scholars were more adaptable and could more easily retrain, this did not mean that it would have been easy as funding was scarce. Ernst Levy (1881-1968) was ousted from his position at the height of his career. He had already sent his daughter Brigitte and her husband Edgar Bodenheimer to the US, where they had studied law at Columbia. Due to help from law professor and Germanophile Karl Llewellyn, they would venture to the West and gain positions, Levy at the law school in Seattle. However, even in their cases, the positive outcome was long and tenuous and the result of a strong family connection and plenty of assistance. Kirchheimer 
settled in the US and Levy considered a return to Germany but never did, perhaps due to the insistence of his family. ${ }^{35}$ Legal papyrologist Hans Julius Wolff (1902-1983) was an example of one's fate if no such support was forthcoming. Wolff was very talented in the extremely specialized field of legal papyrology, the study of ancient papyrus documents mostly found in the Egyptian desert. He was Jewish and sought to escape Germany after 1933. The NGO Notgemeinschaft deutscher Wissenschaftler im Ausland arranged for a job and he left in 1935 to work at the University of Panama. After a few years in Panama, in 1939 he moved to the US, where he worked and studied at several universities in the Midwestern states from Wisconsin to Tennessee. He published some works in English and gained a permanent position as a law librarian at the University of Tennessee. He returned to Germany for a position as professor in $1955 .{ }^{36}$

Even in the UK, those who had entered a university and studied, perhaps doing another doctorate or a professional degree, were considerably more likely to gain employment and friends due to the connections that their studying provided. This was in no way a given. For example, commercial law scholar Clive M. Schmitthoff (1903-1990) enrolled to study at the London School of Economics. However, Schmitthoff and his future wife Ilse "had led a very lonely existence at the LSE, apparently making friends with absolutely no one." ${ }^{37}$ In their case, this isolation proved to be temporary, and Schmitthoff eventually served for five years in the British army and later had a successful legal career. His former teacher in Germany, Martin Wolff (1872-1953), had a much more difficult experience, suffering from the hostile atmosphere in Britain. Like many other older scholars, he felt isolated at Oxford. This is a recurring theme in these biographies; it appeared that even people who had known each other before in Germany did not interact much socially in Britain. Wolff gained little recognition at Oxford; he was allowed to give only one lecture during his whole time there and he was not given any kind of permanent position. ${ }^{38}$

The issue of return is one of the clearest division points with regards to what has been described as adaptation and assimilation. In the descriptions of Italian refugees, they were often said to be almost model emigrants. They demonstrated a clear willingness to assimilate, evidenced by the fact that they collaborated with American institutions and participated in political affairs. They also had a low rate of return after the war ended and produced only a limited number of memoirs. ${ }^{39}$ From this ideal case, we may produce a mirror image, that of the worst-case scenario, the migrant who is aloof and indifferent to what is happening in their adopted country and eschews civil society and contacts. They also return at the earliest possible moment to their country of origin. The writing of memoirs is perhaps the most surprising issue of them all.

The issue of memoirs and adaptability is interesting in the sense that Edgcomb reports about the dozens of German professors in the US who were sent to teach in the traditionally black colleges. She notes that unfortunately none of them described their experience in memoirs. ${ }^{40}$ What for her 
was an unfortunate lack of material may thus have been a positive sign that even though the cultural differences between Germany and the American South were considerable, the German academics never found the time to publish memoirs as their energies were devoted to the present.

One of the few people to write memoirs about their period in exile was legal historian Guido Kisch (1889-1985), who left Germany in 1935 and arrived in New York. He spent a long time searching for any position there, but returned to Germany after the war. His extensive memoirs chronicle his time in exile and the highlights of his desperate search for an academic livelihood. ${ }^{41}$

A special case among exiles relates to those who ended up somewhere other than the UK or the US. There was a considerable influx of scholars who went to Turkey, lured there by a promise of a slew of new jobs. Many of them returned to Germany after the war. The tendency of return was also noticeable among exiles who went to other countries. ${ }^{42}$

The issues of assimilation, adaptation and memoirs hide numerous unstated issues, from the idea that to return or not return was primarily an issue of assimilation rather than the opportunity or willingness to return, be it for financial or psychological opportunities. The writing of memoirs also contains an issue of class, since the publication of memoirs tends to be an activity of leisure, requiring a certain degree of financial security to undertake.

There is a widespread tendency in field-specific studies to say that only their field was badly adaptable to life abroad. This is particularly true with regards to lawyers, but also in other fields. In some cases, the whole field of the humanities is presented as underachieving and willing to return to Germany. ${ }^{43}$

Fitting in and finding a place was a constant challenge, but when successful it brought a new conundrum, that of whether to return. The notion of assimilation and the idea of permanent stay were something that cannot really be discussed as a success issue. For most, the idea of exile was construed as a temporary reprieve, followed by a return home. This was also the idea supported by the British authorities. After the war, some exiles had been away for 12 years and had built new lives abroad. While some of the older exiles such as Schulz and Pringsheim did return, their children opted to stay. For Jewish refugees, the notion of resurgent anti-Semitism did not encourage return.

\section{Victims of sexism and patriarchy}

A completely different issue was the position of women with academic training. Despite the considerable obstacles they faced, women were able to have an academic career in Germany. In exile, numerous external issues, ranging from employment options to the limitations faced by women in academia, prevented female scholars from continuing their careers. For example, pharmacist Emmy Zwillinger was initially gained a permit for household work, before getting an academic job in $1939 .{ }^{44}$ Psychiatrist Nelly Wolffheim (18791965) was not able to get an academic job due to both language difficulties and adaptation. She worked as a model at an art school and sold handmade toys, continuing a scientific career only after the war. ${ }^{45}$ 


\section{Kaius Tuori}

While all refugee scholars suffered from a loss of status and livelihood and struggled to find work that would have matched their qualifications, the situation was especially difficult for female scholars, who in Britain were often able to get only permits to do domestic work. ${ }^{46}$ Even in the US, women were often the first to get a job, albeit often in domestic work. Heilbut notes that often the women were younger and quicker to learn languages, allowing them to integrate into the society better. However, women with doctoral degrees sought primarily to find a job even if it was non-academic, in order to support their families, while men might sought jobs that would allow them to maintain their academic status. This would lead to situations in which a female medical doctor would support her husband's job search by getting a job peeling potatoes. Quack describes how the role of women in exile followed certain patterns in which they would be instrumental in arranging emigration, getting documents and making travel arrangements. In America, perhaps due to the more patriarchal social arrangements, they would revert to either being stay-at-home mothers or non-academic jobs. Sometimes this was also prompted by the fact that universities simply did not hire women to be professors. ${ }^{47}$

This meant that there were numerous forms of structural sexism, from attitudes about family roles to the place of women in the workplace, which made it difficult for women to continue their scholarly career. These were issues that were independent of the people themselves and often beyond their control. Still, it becomes apparent in many of the narratives that women were conditioned to retreat to maintain the domestic sphere at the expense of their own careers. For example, Brigitte Bodenheimer's own career was sidelined after law school by the needs of her father, Ernst Levy and husband Edgar Bodenheimer, whose academic ambitions were seen as primary. ${ }^{48}$

\section{The depressed and the troubled}

The last section of this chapter is also the most dramatic. Many of the scholarly exiles suffered from trauma and mental health issues. This was not uncommon even in the success stories. Schulz was seriously depressed, and his escape was possible only because of the energetic action of his wife Martha. ${ }^{49}$

In other instances, refugee scholars lived a troubled and tragic life in exile. German child psychiatrist Bruno Bettelheim (1903-1990) went to the US, where he gained success as an expert on the psychology of concentration camps, writing many famous articles on the subject. His career was derailed by accusations of multifarious wrongdoing, from plagiarism to fraud. He later committed suicide. ${ }^{50}$

Suicide was already a common response to repression and violence in Germany. This legacy continued in exile. Historian Hedwig Hintze (1884 1942) left Germany in 1939, but stayed in the Netherlands, waiting for a position to open. She was hired as an assistant professor at the New York New School of Social Research in 1941 but failed to get out of Europe. When deportations to camps in the East began in 1942, Hintze committed suicide. ${ }^{51}$ 
Social psychologist Gustav Ichheiser's whole family was killed in the Holocaust. He escaped to Switzerland and from there to London and the US. Despite working in numerous institutions, he found it impossible to obtain a permanent position. He even sought a position as a janitor at the University of Chicago to be able to stay. He fell into poverty and was institutionalized in the 1950s due to mental health problems. He died in hospital in 1969 in a suspected suicide. ${ }^{52}$

There are numerous other instances of suicide. Hungarian computer scientist Klára Dán von Neumann (1911-1963) migrated with her husband to the US and had a successful career, but drowned herself in $1963 .{ }^{53}$ Historian Edgar Zilsel (1891-1944) went to the US via Britain, gaining a Rockefeller Fellowship. He appeared to be working and publishing, even gaining a job at Mills College, before committing suicide. ${ }^{54}$ Socio-legal scholar Georg Rusche committed suicide in London in $1950 . .^{55}$

In all these cases, the impact of the trauma of exile is difficult to estimate. What the fundamental reasons were for such drastic measures as suicide is hard to evaluate and when the time difference between a trauma and suicide is several decades, that is even harder. Nevertheless, exile caused enormous mental health issues, many compounding with the other factors to complicate the difficult tasks of finding a new life.

\section{Conclusions}

In this chapter, I have sought to illuminate some of the challenges faced by exiled scholars through the examples of the people who did not make it to the list of the success stories generally recounted in the literature. Familiar factors, from personal flexibility to contacts and language skills, each contributed to people having encountered difficulties in their time in exile/emigration. What appears from these individual cases is a clear picture of the different hurdles which lie ahead for the academic exiles. While none of them were issues that would have led to someone having to abandon their academic career, they could become that when compounded with other factors. Thus, even though someone like Pringsheim was a difficult person, old and a German nationalist to boot, he had still his loyal friends and supporters and his skills, both language skills and academic prowess. At the same time, one should not be judgmental in saying that all moves away from the academic path were failures. For instance, professor of ancient history Richard Lacqueur (1881-1959) spent 12 years in the US working in odd jobs such as packing in a book store. ${ }^{56}$ We may perhaps be allowed to say that this may not have been a turn for the better for him. On the other hand, whether Arnold Ehrhardt's (1903-1965) turn to studying theology after a career in Roman and civil law was a result of working through traumas of exile is possible, but it certainly cannot be considered a failure. ${ }^{57}$

One of the unstated assumptions of the scholarship on refugee academics is precisely the division between success and failure and ascribing it to either chance or personal qualities. Just as the individual does not make history, 
neither are the stories of success or failure free from the structural realities that lie behind them. Behind those stories of chance encounters and helpful strangers are innumerable connections and facts that shape the probabilities of them taking place, from the language skills that make them possible or the sense of human similarity that encourages someone to make a connection in the first place. Just like the current language, which ascribes laziness or other personal qualities as reasons for marginalization and poverty among immigrants, the pre-eminence of the character and chance with regards to success is a screen and a sham. Connections, language skills, suitability and demand are all features influenced by structural issues, from racism to economic and educational deprivation. As was mentioned in the introduction to this volume, émigré scholars were evaluated and ranked according to their suitability and chance of success, predetermining some for success, others for obscurity. Individual qualities do matter, but they matter only within the structural and societal context.

This notion of structural marginalization is something that connects the historical and the contemporary worlds of the scholars at risk. In both cases, the refugee scholars enter the world of academic precarity in a structural position of downward mobility, as described by Vatansever. They are the flotsam and jetsam of forced migration, the reserve force of the academic labour market. ${ }^{58}$ What the lionization of the few "success stories" does is to enforce a model in which fate of the individual is seen as his or her fault, as the equivalent of the moral choice of poverty.

\section{Acknowledgments}

The author would like to thank the editors and the other collaborators in this project for their insightful comments and suggestions. He also acknowledges a debt of gratitude to Ms Iida Karjalainen and Mr Paul Behne for their invaluable assistance in the collection of material and the final editing of this work. The work has been funded by Academy of Finland-funded Centre of Excellence in Law, Identity and the European Narratives Subproject 1, funding decision numbers 312154 and 336676.

\section{Notes}

1 Jay 1985; Beatson and Zimmerman 2004; Benhabib 2018.

2 Benhabib 2018, 2: “[...] refugees whose names now read like a 'Who's Who' of intellectual

Europe: Hannah Arendt, Andr. Breton, Marc Chagall, Marcel Duchamp, Max Ernst, Siegfried Kracauer, Alma Maria Mahler Gropius Werfel, and others”.

3 Of those who vanish, usually just a casual remark is left, for instance Lehmann and Sheehan 1991, 2-3: "Many other refugees worked in smaller schools, where they carried heavy teaching obligations and had few opportunities for research. And of course, those who suffered most from emigration do not appear in this book: Unable to find an academic job, they simply drop from our view."

4 Referencing silence(s) is quite difficult, in its stead one may refer to the recurring statements below about having to leave academia or ending their scientific career. 
5 Ash and Söllner 1996, 10, 12. See also the chapter of Söllner in this volume.

6 Fermi 1968; Heilbut 1983; Greenberg 1978; Lehmann and Sheehan 1991; Ash and Söllner 1996; Rösch 2014; Jay 1985; Bahr 2007; Kettler 2011; Söllner 2019; the theme issue Writing History in Exile in Storia della Storiografia 69 (2016); Crawford et al. 2017; Benhabib 2018; Friedlander 2018. On legal scholars, see Beatson and Zimmerman 2004; see also Kmak 2019; Graham 2002; Lutter et al. 1993; Breunung and Walther 2012.

7 Camurri 2014.

8 Harlem 2010, 460-474.

9 Heilbut 1983, 28. This marginalization was equally a side product of the very strict immigration laws in Britain. They restricted entry and gave access based on labour shortages in specific fields, such as gardeners and housekeepers. A notorious example of marginalization was the tendency of medical associations in countries such as Britain or Sweden to demand restrictions for Jewish doctors who were seen as competition.

10 Weindling 1996, 86-88.

11 Steinmetz 2010, 1-27.

12 See the chapters by Ali Ali and Carol Bohmer in this volume.

13 Both popular and institutionalized racism were amply present in both British and American academia, with various quotas and hiring bans against Jewish academics.

14 Heilbut 1983, 50; Grenville 2019, 56 et passim.

15 Camurri 2014, 3-4, and Fleck 1996, 219.

16 See also the chapter by Carol Bohmer in this volume.

17 Tuori 2019. Most of these helpers, such as Kenneth Sisam, Francis de Zulueta or F. A. Mann, appear to have been motivated by nothing more than simple kindness and humanity.

18 Crawford et al. 2017, 11.

19 Stiefel and Mecklenburg, 1991, 4.

20 Weindling 1996, 86, footnote 1.

21 Stein 2004, 741 and appendix 772. See also Abrams 2009, 30-32, 194. His son Emil Fackenheim wrote his obituary, Fackenheim 2003.

22 Heilbut 1983, 54.

23 Tuori 2019, 38-39.

24 Breunung and Walther 2012, 577.

25 Breunung and Walther 2012, 576-7.

26 Tuori 2019.

27 Whitaker 2019, 343-345, 350.

28 Tenorth and Horn 1996, 164.

29 Camurri 2014, 5.

30 Wiegandt 2004, 536-581

31 Honoré 2004.

32 Stiefel and Mecklenburg 1991, 54, 56.

33 On Kelsen's exile, see Telman 2016 and Dreier 1993, 705-732.

34 Panofsky 1954, 7-27 and Söllner 1996, 254.

35 Kunkel 1969, 86; Tuori 2020, 78-79.

36 Epstein 1991, 125; Tuori 2020, 80.

37 Adams 2004, 368.

38 Dannermann 2004, 443-461.

39 Camurri 2014, 5. 
40 Edgcomb 1993.

41 Kisch 1975.

42 On the return rates of exiles, see Krauss 2001.

43 Tenorth and Horn 1996, 163-165: "Humanists' (Geisteswissenschaftler), particularly in the the field of education in its German variant, seem to have been confronted with greater problems abroad than natural scientists because of their distinctive way of thinking. For this reason, it may be that they felt more inclined to find their way back to Germany."

44 Fischer 1996, 86, footnote 1.

45 Grenville 2019, 57-58, see also https://jwa.org/encyclopedia/article/wolffheim-nelly.

46 Elsner 2017, 54.

47 Heilbut 1983, 69; Quack 1991, 102-108: "In their lives we can observe a development which proved fundamentally different from their former lives in Germany, namely a trend toward nonacademic occupations: from attorney to social worker, from teacher or doctor to nurse, from university-educated housewife to bakery worker, secretary, or masseuse."

48 Bodenheimer 2016.

49 Ernst 2004, 105-203, at 140.

50 Sutton 1996, 675; Heilbut 1983, 209-211.

51 Kater 1991, 92-93.

52 Rudmin 1987, 165-80.

53 Ulam et al. 1969, 235-269.

54 Fleck 1996, 216, see also footnote 52.

55 Melossi 1980, 51-63.

56 Epstein 1991, 120.

57 Breunung and Walther 2012, 576.

58 Vatansever 2020, 8: “[...] this study attempts to de-romanticize the concept of 'exile' by revealing the structural precarity underneath the glamorized presentation of the displaced academic labor force as quixotic 'freedom fighters'."

\section{Bibliography}

Abrams, Nathan. 2009. Caledonian Jews: A Study of Seven Small Communities in Scotland. Jefferson, NC: McFarland.

Adams, John. 2004. "Clive M. Schmitthoff." In Jurists Uprooted. German-Speaking Emigré Lawyers in Twentieth-Century Britain, edited by Jack Beatson, and Reinhard Zimmermann, 367-380. New York and Oxford: Oxford University Press.

Ash, Mitchell G., and Alfons Söllner, eds. 1996. Forced Migration and Scientific Change: Émigré German-Speaking Scientists and Scholars after 1933. Cambridge: Cambridge University Press.

Bahr, Ehrhard. 2007. Weimar on the Pacific: German Exile Culture in Los Angeles and the Crisis of Modernism. Berkeley: University of California Press.

Beatson, Jack, and Reinhard Zimmerman, eds. 2004. Jurists Uprooted. GermanSpeaking Emigré Lawyers in Twentieth-Century Britain. New York and Oxford: Oxford University Press.

Benhabib, Seyla. 2018. Exile, Statelessness and Migration. Playing Chess with History from Hannah Arendt to Isaiah Berlin. Lawrenceville: Princeton University Press.

Bodenheimer, Rosemarie. 2016. Edgar and Brigitte: A German Jewish Passage to America. Tuscaloosa: University of Alabama Press. 
Breunung, Leonie, and Manfred Walther. 2012. Die Emigration deutscher Rechtswissenschaftler ab 1933, Ein bio-bibliographisches Handbuch. Band 1, Westeuropäische Staaten, Türkei, PalästinalIsrael, lateinamerikanische Staaten, Südafrikanische Union. Göttingen: De Gruyter.

Camurri, Renato. 2014. "The Exile Experience Reconsidered: a Comparative Perspective in European Cultural Migration during the Interwar Period." Transatlantica 1: 1-17. doi:10.4000/transatlantica.6920

Crawford, Sally, Katharina Ulmschneider, and Jás Elsner, eds. 2017. The Ark of Civilization. Refugee Scholars and Oxford University, 1930-1945. Oxford: Oxford University Press.

Dannermann, Gerhard. 2004. "Martin Wolff (1872-1953)." In Jurists Uprooted. German-Speaking Emigré Lawyers in Twentieth-Century Britain, edited by Jack Beatson, and Reinhard Zimmermann, 443-461. New York and Oxford: Oxford University Press.

Dreier, Horst. 1993. "Hans Kelsen (1881-1973). "Jurist des Jahrhunderts?" In Deutsche Juristen Jüdischer Herkunft, edited by Helmut Heinrichs, Hans-Harald Franzki, Klaus Schmalz, and Michael Stolleis, 705-732. Munich: Beck.

Edgcomb, Gabrielle Simon. 1993. From Swastika to Jim Crow: Refugee Scholars at Black Colleges. Malabar, FL: Krieger Publishing Company.

Elsner, Jás. 2017. "Pfeiffer, Fraenkel and Refugee Scholarship in Oxford during and after the Second World War." In The Ark of Civilization. Refugee Scholars and Oxford University, 1930-1945, edited by Sally Crawford, Katharina Ulmschneider, and Jás Elsner, 25-49. Oxford: Oxford University Press.

Epstein, Catherine. 1991. "Schicksalsgeschichte: Refugee Historians in the United States." In An Interrupted Past. German-Speaking Refugee Historians in the United States after 1933, edited by Hartmut Lehmann, and James J. Sheehan, 116-135. Cambridge: Cambridge University Press.

Ernst, Wolfgang. 2004. "Fritz Schulz (1879-1957).” In Jurists Uprooted. GermanSpeaking Emigré Lawyers in Twentieth-Century Britain, edited by Jack Beatson, and Reinhard Zimmermann, 105-203. New York and Oxford: Oxford University Press.

Fackenheim, Emil. 2003. "Addressing Great Philosophical Questions for the Jewish People.” The Guardian, October 10, 2003. https://www.theguardian.com/news/2003/ oct/10/guardianobituaries.

Fermi, Laura. 1968. Illustrious Immigrants: The Intellectual Migration from Europe 1930-1941. Chicago: University of Chicago Press.

Fischer, Klaus. 1996. "Identification of Emigration-Induced Scientific Change." In Forced Migration and Scientific Change. Émigré German-Speaking Scientists and Scholars after 1933, edited by Mitchell G. Ash, and Alfons Söllner, 23-47. Cambridge: Cambridge University Press.

Fleck, Christian. 1996. "Emigration of Social Scientists' Schools from Austria." In Forced Migration and Scientific Change. Émigré German-Speaking Scientists and Scholars after 1933, edited by Mitchell G. Ash, and Alfons Söllner, 198-223. Cambridge: Cambridge University Press.

Friedlander, Judith. 2018. A Light in Dark Times: The New School for Social Research and Its University in Exile. New York: Columbia University Press.

Graham, Kyle. 2002. "The Refugee Jurist and American Law Schools, 1933-1941." American Journal of Comparative Law 50, no. 4: 777-818. doi:10.1093/ajc1/50.4.777.

Greenberg, Karen J. 1978. The Mentor Within: The German Refugee Scholars of the Nazi Period and Their American Context. Unpublished Ph.D. diss., Yale University. 
Grenville, Anthony. 2019. “Academic Refugees in Wartime Oxford.” In Ark of Civilization. Refugee Scholars and Oxford University, 1930-1945, edited by Sally Crawford, Katharina Ulmschneider, and Jaś Elsner, 50-61. Oxford: Oxford University Press.

Harlem, Andrew. 2010. "Exile as a Dissociative State: When a Self is 'Lost in Transit'." Psychoanalytic Psychology 27, no. 4: 460-474. doi:10.1037/a0020755.

Heilbut, Anthony. 1983. Exiled in Paradise. German Refugee Artists and Intellectuals in America from the 1930's to the Present. Boston: Beacon Press.

Honoré, Tony. 2004. "Fritz Pringsheim (1882-1967).” In Jurists Uprooted. GermanSpeaking Emigré Lawyers in Twentieth-Century Britain, edited by Jack Beatson, and Reinhard Zimmermann, 205-232. New York and Oxford: Oxford University Press.

Jay, Martin. 1985. Permanent Exiles: Essays On the Intellectual Migration From Germany to America. New York: Columbia University Press.

Kater, Michael. 1991. "Refugee Historians in America: Pre-emigration Germany to 1939." In An Interrupted Past. German-Speaking Refugee Historians in the United States after 1933, edited by Harmut Lehmann, and James J. Sheehan, 73-93. Cambridge: Cambridge University Press.

Kettler, David. 2011. The Liquidation of Exile: Studies in the Intellectual Emigration of the 1930s. London and New York: Anthem Press.

Kisch, Guido. 1975. Die Lebensweg eines Rechtshistorikers. Sigmaringen: Thorbecke.

Kmak, Magdalena. 2019. "The Impact of Exile on Law and Legal Science 1934-64." In Roman Law and the Idea of Europe, edited by Kaius Tuori, and Heta Björklund, 15-34. London: Bloomsbury.

Krauss, Marita. 2001. Heimkehr in ein fremdes Land. Geschichte der Remigration nach 1945. Munich: C. H. Beck Verlag.

Kunkel, Wolfgang. 1969. "Ernst Levy zum Gedächtnis.” Zeitschrift der SavignyStiftung für Rechtsgeschichte: Romanistische Abteilung 86, no. 1: xiii-xxxii.

Lehmann, Hartmut, and James J. Sheehan, eds. 1991. An Interrupted Past: Germanspeaking Refugee Historians in the United States after 1933. Cambridge: Cambridge University Press.

Lutter, Marcus, Ernst C. Stiefel, and Michael H. Hoeflich, eds. 1993. Der Einfluß deutscher Emigranten auf die Rechtsentwicklung in den USA und in Deutschland. Vorträge und Referate des Bonner Symposions im September 1991. Tübingen: Mohr Siebeck.

Melossi, Dario. 1980. "Georg Rusche: A Biographical Essay." Crime and Social Justice 14: 51-63.

Panofsky, Erwin. 1954. "Three Decades of Art History in the United States: Impressions of a Transplanted European.” College Art Journal 14, no. 1: 7-27.

Quack, Sibylle. 1991. "Everyday Life and Emigration: The Role of Women.” In $A n$ Interrupted Past. German-Speaking Refugee Historians in the United States after 1933, edited by Harmut Lehmann, and James J. Sheehan, 102-108. Cambridge: Cambridge University Press.

Rösch, Felix. 2014. Émigré Scholars and the Genesis of International Relations: A European Discipline in America? London: Palgrave Macmillan.

Rudmin, Floyd. 1987. "Gustav Ichheiser in the History of Social Psychology: An Early Phenomenology of Social Attribution." British Journal of Social Psychology 26, no. 2: $165-180$.

Söllner, Alfons. 1996. "From Public Law To Political Science? The Emigration of German Scholars after 1933 and Their Influence on the Transformation of a Discipline." In Forced Migration and Scientific Change: Émigré German-Speaking Scientists and Scholars after 1933, edited by Mitchell G. Ash, and Alfons Söllner, 246-272. Cambridge: Cambridge University Press. 
Söllner, Alfons. 2019. Political Scholar Zur Intellektuellengeschichte des 20. Jahrhunderts. Hamburg: CEP Europäische Verlagsgsanstalt.

Stein, Peter. 2004. "Émigré Legal Scholars in Britain - Personal Recollections." In Jurists Uprooted. German-Speaking Emigré Lawyers in Twentieth-Century Britain, edited by Jack Beatson, and Reinhard Zimmermann, 739-742. New York and Oxford: Oxford University Press.

Steinmetz, George. 2010. "Ideas in Exile: Refugees from Nazi Germany and the Failure to Transplant Historical Sociology into the United States." International Journal of Politics, Culture, and Society 23, no. 1: 1-27. 10.1007/S10767-009-9062-Z.

Stiefel, Ernst, and Frank Mecklenburg. 1991. Deutsche Juristen im amerikanischen Exil: (1933-1950). Tübingen: Mohr.

Sutton, Nina. 1996. Bettelheim: A Life and a Legacy. New York: Basic Books cop.

Telman, Jeremy, ed. 2016. Hans Kelsen in America - Selective Affinities and the Mysteries of Academic Influence. Berlin: Springer Verlag.

Tenorth, Heinz-Elmar, and Klaus Horn. 1996. "Impact of Emigration on German Pedagogy." In Forced Migration and Scientific Change: Émigré German-Speaking Scientists and Scholars after 1933, edited by Mitchell G. Ash, and Alfons Söllner, 156-172. Cambridge: Cambridge University Press.

Tuori, Kaius. 2019. "Exiled Romanists between Traditions: Pringsheim, Schulz and Daube." In Roman Law and the Idea of Europe, edited by Kaius Tuori, and Heta Björklund, 35-52. London: Bloomsbury.

Tuori, Kaius. 2020. Empire of Law: Nazi Germany, Exile Scholars and the Battle for the Future of Europe. Cambridge: Cambridge University Press.

Ulam, S., H. W. Kuhn, A. W. Tucker, and Claude E. Shannon. 1969. "John von Neumann, 1903-1957." In Intellectual Migration: Europe and America, 1930-1960, edited by Donald Fleming, and Bernard Bailyn, 235-268. Cambridge, MA: Harvard University Press.

Vatansever, Asl1. 2020. At the Margins of Academia: Exile, Precariousness, and Subjectivity. Leiden and Boston: Brill.

Weindling, Paul. 1996. "The Impact of German Medical Scientists on British Medicine: A Case Study of Oxford, 1933-45." In Forced Migration and Scientific Change: Émigré German-Speaking Scientists and Scholars after 1933, edited by Mitchell G. Ash, and Alfons Söllner, 86-114. Cambridge: Cambridge University Press.

Whitaker, Graham. 2019. "Philosophy in Exile: The Contrasting Experiences of Ernst Cassirer and Raymond Klibansky in Oxford." In The Ark of Civilization: Refugee Scholars and Oxford University, 1930-1945, edited by Sally Crawford, Katharina Ulmschneider, and Jás Elsner, 341-358. Oxford: Oxford University Press.

Wiegandt, Manfred. 2004. "Gerhard Leibholz (1901-1982)." In Jurists Uprooted: German-Speaking Emigré Lawyers in Twentieth-Century Britain, edited by Jack Beatson, and Reinhard Zimmermann, 536-581. New York and Oxford: Oxford University Press. 


\title{
10 Reframing the subject \\ Affective knowledge in the urgency of refuge
}

\author{
Ali Ali
}

\section{Introduction}

In this text, I discuss how the exiled subject's sense and embodiment of precariousness, make it, or fail to make it, into the frames of noteworthy/grievable knowledge - official policy-making and academic registers of knowledge. I centre exile subjects' work with notions of (in)significance, (un)viability and (un) voiceability of their grievances and matters of affective concern, whether to the reproduction of othering/exclusion or to problematizing these. My main concern here is the narratives that circulate in the lives of queer exiles in Finland, and how these could halt referencing, voicing, let alone politicizing their plight and grievances. Affective knowledge risks being eclipsed, or cut out of the frame, in terms of academic and policy-making concerns. In referencing my fieldwork and the work of others, I am trying to do some of the justice due to that knowledge.

Pascucci and Hassouneh show what could happen to affective knowledge in the experience of refugees employed by international aid organizations; refugee subjectivity is often reduced to an instance of technical mediation between humanitarian and aid organizations and those in need. ${ }^{1}$ Understandably, humanitarian and aid workers who themselves have been subject to humanitarian crises, revisit traumas and grievances in the course of their work. They balance that with the composure required for performing their job. This work involves "intense emotional work [that sometimes requires] physical presence in an often dangerous, uncomfortable 'field'."' This first-hand (trauma-related) knowledge, and affective proximity to the loss of fellow nationals makes the refugee/traumatized humanitarian worker familiar both with the situation and with the needs of those targeted by humanitarian work. ${ }^{3}$ This experiential knowledge is, according to the authors, "emotional, [e]mbodied [and] disqualified.", which is reflected in the salary and security enjoyed: "The tasks assigned to refugee workers are often the most labour intensive and least prestigious." 4

In the following reference to my own fieldwork, I also tackle such knowledge: embodied and affectual (two aspects why this knowledge is being disqualified). But more specifically, I dwell on (1) the subject's sense of grief and grievability of their embodied/affective knowledge, (2) and how that informs the terms of making claims in the field of queer refugeehood. My question is

DOI: $10.4324 / 9781003092421-14$ 
how (if at all) matters of loss and grief in the lived experience pass their audition into collective, communal and official visibility in the negotiation of rights and claims-making. Beyond discussing how matters of grief and grievance could be silenced or eclipsed, I tackle how that erasure itself goes ungrieved, and, most importantly, what it takes, and gives, to reframe it (and reframe the knowledge about it) as grievable. This text tackles losses experienced in exile; loss of home, hope and sense of belonging and/or the imaginability of any or all of these. Most specifically, it centres on the collective aspects of that loss. The aim is to question notions of grief seen as a private matter compartmentalized and individualized in discrete subjectivities, in the hope of rethinking collective terms in which we view and (mis)recognize, condone or normalize loss and grief as a side story to the functioning of an otherwise just and sound collectivity, sociality and politics.

\section{A field-ful of loss and grief}

Narratives and embodiments of grief and grievances come up occasionally in the intimacy of ethnographic fieldwork. Traditionally, ethnography values and requires: "a deeper immersion in others' worlds in order to grasp what they experience as meaningful and important [, and experience] the ordinary routines and conditions under which people conduct their lives[.]"5 In their text on exiled scholars (this book), Kmak and Farzamfar show that grief, resentment and grievance are recurrent themes in the experience of exile; the sense of impossibility of returning to one's country of departure evokes a sense of irrevocable loss. The following discussion on narratives of loss touches upon the (imagin)ability of returning "home". But it also tackles what "home" denotes in terms of belonging/community, settlement and security. This is a question of the imaginability of home in exile. And how that (imagin/dis/-)ability, and its affective structure, is experienced and deployed in home-making.

I will speak about how (during my fieldwork) matters of loss of "home", belonging, settlement and/or imaginability of these, are approached. The main field I write from/about is a self-proclaimed LGBTQI+ non-governmental organization, where I chose to initiate my relationship with the fieldwork and the "subjects" of research. I choose the word initiate, to point out that a shared life with other participants ${ }^{6}$ (and the field) went beyond the premises of that organization. Therefore, this text is informed by other fields (or extensions of the initial field): the national Pride and other events, and even planned and accidental walks and talks with other participants.

At the organization, employees and volunteers (who were Finnish or persons with a state-recognized residence permit), asylum seekers and state-recognized refugees met occasionally. Nationality and state recognition was a decisive factor. This meant not only an official permit to settle, work and volunteer. Recognition of the right to settlement also entailed the sense of peace and mooring necessary to imagine social functionality.

The organization was committed to assisting LGBTQI+ asylum seekers in the painstaking bureaucracy of asylum seeking. In addition, it hosted regular 
gatherings, discussions and art- and culture-related activities focused on issues of sexuality and asylum. On my first meeting with the "gate-keeper" of my fieldwork (a Finnish citizen employed as a community worker at the organization), she told me that some people I was going to meet and speak to were "in very bad shape" - people who had been "in the asylum process for years". This, according to her, required that I should be in a "stable [financial and legal/documented] situation". Otherwise, she said, I would not be able to stand the cases. What she said made me uneasy: another reminder of the contingency of my work, research and life on state recognition, which is premised on the duration of my working contract with the university. However, I appreciated how she recognized what state recognition meant to us all, and how she made sure that one is aware of what constantly troubles most of the participants' minds. Beyond this and that, she recognized the role of the state in our capacity to deploy our work/ volunteering/research and life in the very intimacy of each other.

Later, I would notice that state recognition would even affect who is present at meetings. Participants whose asylum claim has been recognized were in less need of the (bureaucratic and emotional) support of the organization and the sense of community it created. Inversely, a negative decision issued by the state, or complications in the process of asylum application, could overwhelm a participant and make them too grief-stricken to show up. Being grief-stricken can curb or paralyze one's sociality. But there is another aspect of the story: the privatization of grief: the participants' very (un)imaginability of their plight and grief as a collectively urgent and emergent matter of concern, namely, more than a side note to the functioning of the organization, or - in a broader sense - to society and the state in Finland/Europe (and modern democracy imagined as such).

\section{A note on grief}

My use of the notions of "grief" and "mourning" is not secondary (metaphorical) to the loss of a loved person. It foregrounds the affective gravity and loss that may accompany the state of exile. This branches into several senses of loss: loss of home, language, or trust in liveability in the very places one pinned one's sense of safety on; and, as importantly, loss of trust in the safety narratives that were once too promising not to (wholeheartedly) invest in (and therefore venture into exile).

Grief, in Thomas Attig's words, requires "mak[ing] sense of [a] new reality and find[ing] meaning in life". ${ }^{7}$ Asylum seekers persist/live through protracted loss and a tenuous process of (sometimes) recurrent losses and rejections and (re-)appeals to the court and state authorities. Making sense of that reality seems to require remarkable mourning capacities, not only towards state assurances of protection, but also towards the very sense of entitlement and (belonging) that is lost to narratives of criminalization and othering. It is the grief of ditched hope (in finding peace and protection from one's trouble) raised to the power of being condemned as trouble (and cause of grief) itself. Ironically, the gravity of the situation of people in exile, especially for those 
denied state recognition, rather than being the premises and momentum for socio-political change that recognizes their vulnerability, is often politicized and administered to their further disfavour and discredit. As Kmak (2020) argues, the same approach that "produces" undocumented migrants, forces them to travel, work and live illegally, which, in turn, produces the very narratives of "unassimilable difference" assuming inherent inability to adhere to national norms and values. ${ }^{8}$

Attig foregrounds the point of choice and active grieving. For him, bereavement can be choiceless, but grieving is active and puts one before a wide array of choices. Reconfiguring life under loss involves creating alternatives for survival that one never imagined before, and never could have. This overwhelming array of choices, according to Attig, might be a reason why one chooses to settle on longing for who (or what) we have lost, rather than opting for the "unsettling alternative of facing an overwhelming array of choices." This array of choices might destabilize what it means to be oneself and how to make sense of that self within grievable circumstances. For Butler, grief is overwhelming because of the self dis-/re-orientation it entails:

When we lose certain people, or when we are dispossessed from a place, or a community, [we] not only mourn the loss, but [we] become inscrutable to [ourselves]. On one level, I think I have lost "you" only to discover that "I" have gone missing as well. ${ }^{10}$

In what follows, I will discuss how stories and embodiments of grief were present in participants' lives. But beyond that, I discuss how loss, grief and grievance make or fail to make a noteworthy apparition into media and political registers, and what this entails in terms of narratives of selfhood and collectivity.

\section{Meeting the subjects}

I will start with Sami, who was one of the participants favoured by the state. His right to reside in Finland was recognized four years before our first encounter. He looked/acted confused when he knew that I was researching and writing about queer migrants in exile. "What exactly are you expecting to find out?" He asked. I answered: "How people change when they are in exile". Sami said that he had been in Finland for four years and he had never changed. He had always had the same "way of thinking". I asked him, trying to tease out nuances in his argument, "but don't you change your clothes?" He said that he had always dressed in black, "even back in Iraq".

Ridiculing change does not reflect denial of change per se, but of its research significance. Sami knew that changes happen in exile. He himself, a few minutes after his comment about (non-)change, asked me to translate English words he could no longer remember the equivalent of in Arabic. He said that he "stutter[s] when speaking to [his] mother" because he had "lost touch with Arabic". 
Sami worked for a business that, he said, "makes bargains in thousands and millions of euros". Then he added, "it matters a great deal at which angle the window shades are open, and how the furniture, the glasses and the drinks are set and organized". For him, "these trivial details could affect big things". In such intricate matters, "you are speaking in thousands and millions of euros here", he repeated. I did not disagree. To the contrary, in this text, I want to invoke how trivialized things count; that Sami's forgetting some Arabic words, having always dressed in black and having had (or rather having claimed to have had) "the same way of thinking" counted, even though, or especially because, he presented these as side stories; to how other details mattered in mass trade.

Comments on change and its (in)significance came up occasionally in the field. At a Christmas dinner at the organization, I had a conversation with Mani, an old participant whom I met at the beginning of my research, and who introduced me to the group and the gatekeepers. I asked why he would not show up more often at the meetings. It was only at that event that I had seen Mani at the organization. In fact, it was thanks to him, and his previous involvement and familiarity with the group, that I managed to find my way into the organization as a participant and researcher.

Mani answered in a cynical, but solemn manner: "believe me, nothing changes here". He presented that thinking as an insider's knowledge, from his long experience and involvement. His very long experience was what made the comment more alarming. The change that Mani seemed to mean was the change in the legal status of the participants. Non-change meant a protracted state of limbo and uncertain hope in recognised/legalised status on the part of undocumented participants. Most of these, as mentioned before, frequented meetings in their state of alienation from the country and society during their first months after arrival or after years of protracted legal limbo and depleted hopes of settlement. The latter needed community and consolation when rejection of their asylum claim curbed most other alternatives, or imaginations of them. Participants whose status was legalized (as in the case of Mani) tended to appear less often, mostly due to their engagement in other projects (work and study) that their legalized status opened up for them.

I will disagree with Mani: that nothing seemed to change in the registers of state recognition necessitated more presence and more talk about what changes in the affective registers of those who were involved: Why and how this façade of non-change overshadowed change and turbulence in their lives.

At another instance, the issue of change and its significance came up again with Sana (back then a new participant who had just arrived in Finland). She asked, "What do you expect to find here?", pointing her hands scornfully around the room where we meet weekly. She said she could not understand how my "participation in the art therapy session at the organization would be of any research interest". I said I wanted to know how "people survive their insecurity and sense of alienation in exile". Sana looked more puzzled and cynical than she had been before my answer, "You escaped insecurity and alienation! What insecurity and what alienation are you speaking about here? 
You'd better go and commit suicide if you feel insecure here!" Sana's short stay in the country might have been a factor in how mindful she was of issues of alienation. She might not have recognized yet that suicide and self-hurt was a possible, even recurrent, theme in the narratives and bodies of many participants. But there is more to this story.

Sana "admit[ted] how serious" it was that Jamil and Gabi, two other participants, had been recurrently rejected as asylum seekers and had been undocumented for five years. However, what seemed to make the issue of less academic significance for her was that they were "not dying of hunger", and nor were they "homeless". Sana said that their sense of insecurity was because they "look[ed] at the empty half of the glass". Then she switched from her Iraqi dialect to Syrian (my dialect) and articulated another expression: "hnne 'am ynakdu 'ala halon", meaning "It is because of their own ill-temper/pessimism/ self-victimization [that they make it harder for themselves to cope with the situation]." As if she would capture the situation by pointing out linguistic tropes that I was more familiar with; as if familiarity and normativity were to refute the existence of a problem rather than they themselves being the problem.

In fact, Sana herself was not in an easy situation. Having to speak and think about the issue must have been strenuous when she was waiting for a decision from the Finnish authorities on her asylum claim. Sana herself insisted that she could "not afford not to be strong" - and if she felt disempowered or insecure in Finland "ahsanli ruh antaher", "I am better off committing suicide". (Another expression that is normalized in everyday Arabic meaning: one's life would stop making sense; death would make more sense.) And with that, Sana repeated her allocation of the problem to individual responsibility rather than structural emergencies; an individualized trauma in an otherwise well-functioning totality.

I want to challenge this normative individualization of trauma and grief: privatizing grief into a tacit side story to the inertia of politics and social structure. Grief, according to Judith Butler, can be made into a "resource for politics". It is not "privatizing", "depoliticizing" or "return[ing] us to a solitary situation", but "furnishes a sense of political community [...] by bringing to the fore the relational ties that have implications for theorizing fundamental dependency and ethical responsibility". ${ }^{11}$

Sami's, Mani's and Sana's narratives privatized exile-related grief and denied its research-deservability as a collective or political emergency. I want to bring to the fore that these narratives circulated in the very premises where our meetings took place, that is, within the very community that Sana and other asylum seekers always referred to as "a family". That community/family was premised on honouring the participants' issues of asylum mundanity and affectuality. But that erasure was set against another common narrative that confines the problem to the subjectivities of asylum seekers. This manifested in Sana's statement, directed to Gabi and Jamil at the end of the conversation: "you must have done something wrong! You must have made a mistake in your applications[.] Otherwise, why all this delay in getting a residence permit?" 


\section{"Fake cases"}

Speaking of the wrongs committed by those wronged/disfavoured by the authorities, rather than valuing their capacity to cope, is common in official and mundane narratives of asylum. Deniz Akin argues that queer asylum seekers strategically narrate their sexuality as a "loud and proud sexual identity[,] readable [as] worthy of protection". In that, the seeker not only invests in the narrative to qualify for protection, but transcends that into "policing sexualities" and deeming certain asylum seekers as fake. ${ }^{12}$

What I experienced in the field was that official rejection of an asylum claim was deemed a "fake case" (discrediting a rejected seeker) by fellow seekers. At this point, it is crucial to mention that the authorities' rejection of applicants' claims is often premised on the person's assessed ability to live their (homo) sexuality discreetly. And that assessment, in itself, could enact a serious disregard of the seeker's need for protection. Paradoxically, a negative state decision was viewed by most fellow participants as a condemnation and discredit to the disfavoured/rejected asylum seeker. This thwarted the need further, and tightened the space for grievability for the disfavoured. It also led to tacit and reciprocated stigmatization - that was often "confided" to me and "real" asylum seekers. This made several participants apprehensive and uncomfortable in each other's presence, as indeed happened within the "safe space" that the organization and the participants claimed, or were supposed, to create.

Those "rejected" were often abbreviated in narratives of (un)deservability and rivalry that verged on hostility to "fake cases". The subject/story of exile/ asylum was narrated as a plea to the government being unjustly unfairly misused and depleted by some (the undeserving), and only therefore unjust to others. As Koçak highlights, in matters of claims for resettlement to the UNHCR authorities in Turkey, "fake LGBT refugees" are seen as abusing a "scarce resource" of "golden cases". In that, Koçak argues:

Queer refugees are asked to turn their complicated experiences of political, social and economic displacement into coherent stories of "wellfounded fear" of strictly political persecution as a result of their sexuality and gender identities. ${ }^{13}$

This makes the right to protection - a collective matter of concern grieved, sought and premised on its very collectivity: human rights - into a scarce resource that needs to be bargained for. This not only privatizes grief and precludes its political momentum. It also turns grief into a source of shame and stigma in the very milieus where that grief is most likely to be empathized with, that is, among fellow exiles tackling the same political and social disenfranchisement.

\section{"Son of tribes"}

I discussed above how narratives of unassimilable difference, othering and stigmatization invade the mundane encounters of the disfavoured (read as 
fake and fraudulent). With this tightening of recognition (even to the grievability of non-recognition), the grief and grievance of that seeker starts to assume the coordinates of their bodies and/or their national and cultural belongings. There seemed to be a recurrent and self-evident, therefore undwelled-upon, vilification of "countries of origin" in the field (of LGBT/ queer asylum) in Finland. At a Helsinki Pride debate (2019), a participant from an "Arab country" was asked "What challenges have asylum seekers faced in their own peer groups?" He replied that the question answered itself and then added with a cynical, but conclusive and defeatist tone, "the bleak sides of our culture". The speaker used "our culture" and "Arab culture" interchangeably. In that, "our culture" was crammed into a dismissive remark to span tens of nation-states, and who knows how many cultures. This is ironic, knowing that finding safe and just terms to share a "home" (a place of shared intimacy) with someone is not an easy matter, no matter what the culture is, let alone in an asylum camp, where one does not usually have a say in choosing one's intimates, or fellow inmates.

As the debate continued, a speaker from "another Arab country" spoke (also on behalf of many, if not most or all other Arabs) about how proving one's sexual identity is difficult when "Western standards are different". The paradox, according to him, was that "gender sensitivity is something made for white Europeans with a good education". He added that intercultural differences make it harder for asylum seekers to speak "the language of the authorities", and prove their claim of sexual identity. It is necessary to disclose that "the language of authorities" disfavours asylum seekers who, in their negotiation for asylum, are read as unworthy of (or not in need of) protection. Still, speaking of unbridgeable differences, and allocating "gender sensitivity" according to that difference (short of evoking the shared responsibility and ability on the part of those on both sides of the gap/difference to bridge that gap), echoes that injury and essentialises the boundaries.

In such milieus, arguments weighted with stiff notions of culture seem to have become axiomized. Jungar and Peltonen mention a statement made at Turku Pride, "[T]hese people come from a different culture. They are taught to hide their sexuality, the culture of honour is so strong there." The statement was voiced as supportive of disfavoured (rejected) asylum seekers; as calling attention to issues of culture and their impact on the ability to narrate one's sexuality. ${ }^{14}$ Interestingly, the claim was made at a Pride event: I suggest that "honour" in hiding one's sexuality and "pride" in flaunting it, imply similarity rather than difference between cultures.

Beyond the experience of exile and asylum, notions of culture were at play in the early formation of so-called Arab nationalism. Arab nationalism accompanied the cultural change that happened in the late 19th-early 20th century, referred to in contemporary literature and school curricula as 'Asr al-Nahdah "age of ascendence/resurrection" but translated into English as 'Renaissance', referencing or echoing an authentic European Renaissance. That nationalism was premised on colonizing narratives that seized the intimate and sexual. Massad argues: 
The new renaissance of Arab knowledge production involved an increased acquaintance with European Orientalist thought and the construction of the Arab within it. [The] Arab nationalist project informed by European notions of progress and modernization and a Victorian sexual ethic [required colonial concepts like] thaqafah (culture), inhilal (degeneration), inhitat (decadence or degradation), taqaddum (progress), ta'akhkhur (backwardness), jins (sex), and shudhudh (deviance), among others. [T] he use of European notions on which to base these efforts at excavating Arab-Islamic national heritage did not seem contradictory or problematic to our authors. ${ }^{15}$

The (Arab) nationalist project required excavation of a national heritage. That heritage, when reassembled and introduced by nationalist and nationalist intellectuals, would follow Victorian/colonial norms of decency and sexual mores that accompanied modernization. This back then (ironically) required censoring literature on same-sex love, which inspired agents of cultural production of the period to omit these accounts. ${ }^{16}$ These acts of omission were neither mourned nor seen as losses. Norms of authentication were themselves alienating and shaming, defining what is perversion or fake to a monolithic authenticity. Authentication required shedding reference to same-sex love, a theme that was not uncommon in medieval and pre-colonial Arabic-speaking literature. ${ }^{17}$ Arguably, these references could (have) be(en) precious to people who need(ed) to find solace and mooring in their "authentic" heritage or culture, so to speak. Instead, many Arab queers after centuries of Victorian morality-inspired censorship might have (had) to find mooring and authenticity only in the "loud and proud" rainbow identity; the only (or rather the loudest) one. Therefore, I chose to use the term queer in my study.

This means that "culture" can be partly shaped by ungrieved omissions of what used to be culture: the erasure or overshadowing of the non-heteronormative self from the national. Massad sees that what is being universalized in the encounter (or what he calls collusion) between Western human rights groups/organizations and diasporic members is not only a "Eurocentric culture", but a "culture that has important class attributes and therefore serious consequences for those unfit to defend themselves". ${ }^{18}$

Recurrent recourse to notions of "our/their culture" for an argument necessitates further consideration of their embodiment by the people of a given "culture". Many participants, in my study, often expressed or shared a sense of incapacity to negotiate with the authorities due to taking cultural difference for granted; i.e. as a final/central, rather than transitory argument, in the plea for rights and protection. One's culture/origin, in some instances, was a condemnatory aspect that asylum seekers bore the brunt of and shame for, rather than an issue to be worked through by different parties in enacting a world where the right to protection matters, no matter what. "I am a son of tribes - I do not know how to speak with judges." said Ido, with an air of panic, a few weeks before the court hearing regarding his appeal against the state's rejection of his asylum claim. He added anxiously, "I do 
not have the education for that." I asked Ido if speaking about waiting in permanent anxiety for recognition of his need to stay in Finland (and fear of being deported back to Iraq) required education. Ido did not even seem to dwell on my comment. He insisted that the main issue was to convince the judge that he was "gay". He added that he was told that vulgar language was not an option at the court. Details like these are quite likely to be serious matters of concern to Ido (and others). "Culture" was a stigma they seemed to carry everywhere: to the weekly meetings at the organization, to Pride events, to the court and to the bone; their subjectivity almost reduced to that stigma. This seemed to deplete the seekers' morale and their imagination of political possibilities beyond othering/exclusion.

Ido had a considerable (and mournful) sense of apprehension towards (and alienation from) the authorities whose protection he sought, and to whom he had to confide intimate issues and embodiments. Along with that process, he had to keep composure and decency, and bear responsibility for his "lack" of education, as if the right to protection is premised on the applicant's (cultural and academic) credentials.

Ido's statements reminded me of another case: A mother of a queer asylum seeker once asked me how to reply if she were asked how she reacted when she knew about her daughter's sexuality. The mother and the daughter applied for asylum based on threats to both in their place of origin. "I cannot say I was shocked. Can I?" she asked, sceptically. The question sounded more of a resentful confession than something she could have voiced during the interview with/interrogation by state officials. I (and arguably the officials who were going to interview the mother) would find the story (the child's homosexuality) more credible with the mother's shock: a shock from learning something intimate about one's child that one had never managed to know before; shock from long-lasting unknowability rather than (only) homophobia. The issue was to prove her child's homosexuality as a "real case". Other matters of grievance to the mother, even though necessary to credit the "realness" of the case, were unthinkable, especially if it is drilled into us that denouncing "our culture" is all that matters in one's plea for protection and rights.

If the credibility of asylum claims matters, it also matters how some sought protection from authorities and state officials towards whom they felt resentment and a deep sense of alienation. This meant alienation from those to whom one exposes one's utmost and innermost intimacy, while at the same time feeling a great deal of apprehension - it resonates of (self-inflicted) harassment, unwelcome but imposed/necessary/urgent intrusion into one's intimacy. Malene Jacobsen sees that, for refugees in Denmark, this intrusion happened through integration policies and the biopolitics involved. In some cases, these policies suspended the right to family reunification (therefore keeping family members apart). The intrusion also involved living with the rhetoric of Danish state media and national TV (followed by several of Jacobsen's interviewees) rich in talk, news and debates on whether and how to limit the number of "refugees". ${ }^{19}$ That intrusion experienced in an intimate encounter with the state (representatives), for Jacobsen's interviewees, merited the name of harb 
nafsia. The term can be roughly translated into "psychological war" but has more connotation of nafs (spirit, self and psyche), which makes it an attack on one's self, spirit and morale. That is something intimate, personal and aimed at a specific person. Interestingly, the term harb nafsia was also used by one of the participants in my research also to denote a deliberate effort on the part of the state to "break the morale of the refugee and make them give up". "They want us to kill ourselves", the three-time rejected asylum seeker (and survivor of a suicide attempt) pointed out in one of our conversations. Jacobsen's argument is to "challenge the idealized notion of [country of] refuge as a space beyond war and violence, [where] spaces of war and refuge stretch and fold into one another". I want to build on that and argue how this intimacy of refuge/war is lived in paradoxical terms; where the refugee or the seeker's grievances and losses, rather than bing acknowledged and empathised, are suppressed, muffled, even sometimes reduced to shame and underservability.

Understandably, there is even more intimacy between the seeker and the state authorities in LGBT/queer claims (matters of sex(uality)). But - as Jacobsen argues - the issue goes beyond instances of interrogation and discrediting. That is, even in cases where the seeker is recognised and their status legalised, the very idea of integration (as assimilation) reflects a "history of locating the 'problem' of refugees within the bodies and minds of the refugees themselves". ${ }^{20}$ Here, the paradox is, as Jacobsen argues, how geopolitical conditions that produced a mass displacement in the first place, confine that war in the minds and bodies of refugees. How is it that bodies have to withstand injury and the grievance with composure, even the very injury that necessitated the appeal for protection in the first place? That precarity, grief, and sense of loss seem to become a side story to the "real case" even in the intimate lives of exiles.

\section{Negotiating an authentic self in othering terms}

The issue of "undocumented", "rejected" and "fake" cases transcends technical and categorical disenfranchisement, to the construction of an undeserving subject/selfhood set against a monolithic/hegemonic authenticity. It is a creation of a fake/undeserving identity, and, to use Butler's terms, an "abjection", where the "the real [rather than being an essential identity] is the permanent structure that differentiates [between the abject and the recognized] [i]n relation to the temporal location of th[e] loss [the rejection]" ${ }^{21}$

Building on that, I see another important issue at play in "abjection": the issue of how to narrate that loss, and how to make sense (or preferably nonsense) of authentication that is conditioned on the alienation of one's subjectivity and embodied narratives (of one's reality).

Yasin, a five-year undocumented asylum seeker, spoke of his imagination of Europe before his experience in Finland, and how his view of Europe changed. "In our imagination [before exile], Finland did not wrong anybody. And here we realized that Finland does not wrong its own people". I asked Yasin, "what about you?" He answered, frustrated, "I am not one of Finland's 
people!" Part of his frustration was that his statement was clear enough, and he was clearly not a Finnish citizen, which made my question sound more of an irrelevant teaser. But it was a teaser of another kind, of a kind that Yasin might or might have not recognized. What does Yasin's situation say about Finland and its people? What about the excluded Yasin? And even if Yasin recognized this sense of the question, it could have been a reason why he replied in a frustrated/exasperated manner. My question plays on the sense of loss that Yasin had to deal with. Grieving exclusion from an idealized community entails grieving the loss of that very ideal along with the mooring, settlement and understanding of selfhood and alterity (otherness) (the other with whom one is enthralled).

For Yasin the loss was partly justified by the fact that his arrival and seeking asylum coincided with "happenings in the world", the emergence of the Islamic State and increasing stigma against Arabs and Muslims. Yasin's comments about Finland not wronging its own people was juxtaposed with, and almost if not fully explained by, the increased stigma of Arabs and Muslims. This, according to him, led the Finnish authorities to take stricter measures that affected his case. Here the loss is a loss of the self, a self with recognition and acknowledgement of the loss of the object. Sometimes it seems better, in Butler's terms "to be enthralled with what is impoverished or abusive than not to be enthralled at all and so to lose the condition of one's being and becoming". 22

In Yasin's case, grieving seems to necessitate repudiation of an enthrallment that sustained the imagination of how he made sense of his life and self. That imagination and enthrallment was once, and arguably is still, so significant that Yasin abandoned his country of departure to live in a limbo between the spectre of the idealized and the nightmare of deportation. It seems scary to come to terms with the now-swaggering certainty of that ideal. It can even be risky.

When grieving is feared, when it is not recognized or acknowledged, Butler argues:

our fears can give rise to the impulse to resolve it quickly, to banish it in the name of an action invested with the power to restore the loss or return the world to a former order, or to reinvigorate a fantasy that the world formerly was orderly. ${ }^{23}$

That desire to restore former order, and a "fantasy of the world formerly orderly", manifested itself in short-circuiting the problem in the (national) self. Is it risky to think of loss in different terms? That is the loss of world politics where identity (or origin) does not oust people from entitlement and disappoint their hopes in belonging and security; the loss of a circumstance/ world where security/safety/peace is unconditional, not conditioned on one's belonging and identity.

Does fear of tackling this massive issue of world politics lead us to uphold a fantasy that the world had been orderly and was even becoming more orderly with intensification of that orderliness? Saifo, a three-time rejected 
asylum seeker, critiqued Migri (the Finnish migration and asylum bureaucracy) for not investing in a "technology" that discovers who is a liar ("fake case"), as if technological progress could have solved the problem, rather than rethinking/resenting the terms on which that progress is premised.

\section{Reworking choice and collectivity into the frame of grief/grieving}

What norms does that progress rest upon - norms that seem to make progress proportional to its exclusion of the othered? What transcends the self and the other are the norms of recognition on which the self and the other are fundamentally dependent. ${ }^{24}$ Voicing grievability is an act of active grieving. It changes the sense of one's reality and orientation to one's world and collective/communal conditions, and the norms and terms on which that reality rests. As Monica Varsanyi shows, in the US context, acts of claims-making (what I call acts of collective mobilization of resentment/grievance/grief) by undocumented migrants, created "alternate [also in Varsanyi's terms, urban] models of belonging". ${ }^{25}$ This recalls what Nordling et al. call "spaces 'in between' [created by] encounters between citizens and non-citizens" (in the case of undocumented migrants in Sweden). ${ }^{26}$ Grieving was embodied and voiced from the "very limited social space" available in the case of irregularity. That space was tightened by lack of legal status, the threat of deportation and increased surveillance. ${ }^{27}$ This is a tightened space impacted by recurrent and spiralling loss: disenfranchisement from citizenship and inflicting further injury (stigma) that upholds that exclusion.

"[S]paces in between" and "alternate modes of belonging", formed by collective acts of grieving, led, in the case of undocumented migrants in Sweden, to "an increase in the application of the concept of irregular migrants (papperslösa) in reports and social policies[,] media and parliamentary protocols". ${ }^{28}$ This was crucial in the Swedish context, where, as Sager argues, "[visibility and identity politics are] central for the distribution of welfare services and rights" ${ }^{29}$ A crucial point in these momentous acts of public grieving is that violence, injury and "crisis" were not confined to a subject or identity. This evokes Butler's statement: "The act of violence enacts the social structure, and the social structure exceeds each of the acts of violence by which it is manifested and reproduced." ${ }^{30}$ Sager makes an empirical point of that, by reframing the issue of clandestineness in Sweden as an issue that touches upon the very state of Sweden and the meaning of citizenship:

Instead of asking only 'what can we learn about the situations of asylum seekers?' I want to add the question 'what can we say about the state of things in the Swedish welfare state if we start out from the experiences of asylum seekers in Sweden?'31

Sager also argues that citizenship is not static, and the othered figure of the asylum seeker is at the heart of negotiations for recognition and rights. Citizenship is a manifestation of norms that shape understandings of a sense of belonging and entitlement. And these norms are being constantly negotiated. 
[C]itizenship is always differentiated and unfinished, and the differentiations and categorisations entailed in migration control have consequences in the lives and positions of not only migrants but also permanent residents and formal citizens. Parallel to this, the tension between visibility and invisibility is not only limited to irregular migrants but also at work in the positions of racialised groups in general, including citizens. ${ }^{32}$

This blurs the boundary between matters of asylum concerns and matters of citizenship and reframes the othered as constitutive of the realm of the self. Sager shows that issues of citizenship do not stop at boundaries but involve different actors in serious issues that define what it is to be a citizen and what citizenship means in a state like Sweden.

Magalhães and Sumari ${ }^{33}$ argue that specific categorizations (like nationalities) have come to be seen as essential lines of division that "ran[k] above all other individual and collective subjectivities". These categories created tropes of strangers and strangeness that drowned out similarities and commonalities. Perhaps the hope is to re-centre the dimensions of a basic sameness by exposing the limitation of notions of nationality. In that concern, Paul Gilroy suggests that

We need to consider whether the scale upon which sameness and difference are calculated might be altered productively so that the strangeness of strangers goes out of focus and other dimensions of a basic sameness can be acknowledged and made significant. ${ }^{34}$

\section{Conclusion}

This text is akin to an act of grieving for refugee knowledges and grievances, including my own, that may risk going extinct if it were not for acts and mentions of grieving and grievability by participants, friends, fellow-exiles, authors and others, many of whom I referenced in this text. In this, I am inspired by Thom van Dooren's notion that writing about grief, grievability and mourning, can in itself be an act of mourning that challenges notions of exceptionalism: "[M]ourning undoes any pretense toward exceptionalism, instead drawing us into an awareness of [c]ontinuities and connectivities that make life possible for everyone." ${ }^{35}$ Van Dooren suggests that what should be mourned is lack of mourning itself. Perhaps, mourning breaks the vicious and unending cycle of rivalry for specialness. As Trinh Min-ha puts it, one is soothed with soporific specialness ${ }^{36}$ when privilege and a sense of specialness "easily creates a distance - if not a division - between I-who-have-made-it [the real/authentic] and You-who-cannot-make-it [the fake]." ${ }^{37}$ I suggest mourning as embracing the stigma: whether in grief or pride/honour, that the subject and the knowledge survives the political loss. It is grieving the loss of a world in which we can deal with loss, rather than leaving the issue for the private sphere and the private sector. That is, by politicising, rather than by privatising and compartmentalising grief in categories and bodies. Political 
work should be healing, as Silvia Federici argues: "Being able to politicize our pain, turn it into a source of knowledge, into something that connects us to other people - all of this has a healing power." 38

It is a matter of survival, and fitness - so to speak- to be able to politicize our pain and stigma and transform them into a source of strength and knowledge. Sylvia Wynter suggests that "human" is "meta-Darwinially [h]ybrid being, both bios and logos", 39 biologically evolving but entangled with the myth that biology is embedded in: "simultaneously storytelling and biological being".$^{40}$ In that sense, there could be possibilities of a more survivable story/ narrative: living one's agony and grief in a more survivable manner.

\section{Acknowledgments}

This work is part of the Academy of Finland-funded Centre of Excellence in Law, Identity and the European Narratives (funding decision numbers 312431 and 336678).

\section{Notes}

1 Pascucci and Hassouneh, in this volume.

2 Pascucci and Hassouneh, in this volume.

3 Pascucci and Hassouneh, in this volume.

4 Pascucci and Hassouneh, in this volume.

5 Emerson, Fretz, and Shaw, 2011, 3.

6 I will use "subject" and "participant" interchangeably, to do justice to my experience as a participant(-observer) in the field.

7 Attig, 2011, 47.

8 Kmak, 2020.

9 Attig, 2011, 53.

10 Butler, 2003.

11 Butler, 2003.

12 Akin, 2017.

13 Koçak, 2020.

14 Peltonen and Jungar, 2018, 62.

15 Massad, 2007, 53.

16 Massad, 2007.

17 El-Rouayheb, 2005.

18 Massad, 2007, 39.

19 Jacobsen, Forthcoming.

20 Jacobsen, Forthcoming.

21 Butler, 2011 [1993], 154.

22 Butler, 2004, 45.

23 Butler, 2003.

24 Butler, 2004.

25 Varsanyi, 2006.

26 Nordling, Sager, and Söderman, 2017.

27 Sager, 2018.

28 Sager, 2018. 
29 Sager, 2018.

30 Butler, 2020.

31 Sager, 2011, 19.

32 Sager, 2018.

33 Magalhães and Sumari, in this volume.

34 Gilroy, 2004, 3.

35 van Dooren, 2014, 126.

36 Minh-ha, 1989, 88.

37 Minh-ha, 1989, 86.

38 Federici, 2018, 126.

39 Wynter, 2015, 16-17.

40 Wynter, 2015, 29.

\section{References}

Akin, Deniz. 2017. "Queer Asylum Seekers: Translating Sexuality in Norway.” Journal of Ethnic and Migration Studies 43, no. 3: 458-474.

Attig, Thomas. 2011. How We Grieve: Relearning the World. Rev. ed. Oxford: Oxford University Press.

Butler, Judith. 2003. "Violence, Mourning, Politics." Studies in Gender and Sexuality 4, no. 1: 9-37.

Butler, Judith. 2004. Precarious Life. London: Verso.

Butler, Judith. 2011. Bodies that Matter. 2nd ed. New York: Routledge.

Butler, Judith. 2020. "Judith Butler on Rethinking Vulnerability, Violence, Resistance." Verso (blog), March 6, 2020. Accessed December 4, 2020. https://www.versobooks. com/blogs/4583-judith-butler-on-rethinking-vulnerability-violence-resistance.

El-Rouayheb, Khaled. 2005. Before Homosexuality in the Arabic-Islamic World, 1500-1800. Chicago: Chicago University Press.

Emerson, Robert, Rachel Fretz, and Linda Shaw. 2011. Writing Ethnographic Fieldnotes. 2nd ed. Chicago and London: The University of Chicago Press.

Federici, Silvia. 2018. Re-enchanting the World: Feminism and the Politics of the Commons. Oakland: PM Press.

Gilroy, Paul. 2004. After Empire: Melancholia or Convivial Culture. Oxfordshire: Routledge. Jacobsen, Malene. Forthcoming. "Wars in Refuge: Locating Syrians' Intimate Knowledges of Violence across Time and Space." Political Geography. doi: 10.1016/j.polgeo.2021.102488

Kmak, Magdalena. 2020. "The Right to have Rights of Undocumented Migrants: Inadequacy and Rigidity of Legal Categories of Migrants and Minorities in International Law of Human Rights." The International Journal of Human Rights 24, no. 8: 1201-1217.

Koçak, Mert. 2020. "Who is 'Queerer' and Deserves Resettlement?: Queer Asylum Seekers and Their Deservingness of Refugee Status in Turkey." Middle East Critique 29, no. 1: 29-46.

Massad, Joseph A. 2007. Desiring Arabs. Chicago and London: The University of Chicago Press.

Minh-Ha, Trinh T. 1989. Woman, Native, Other, Writing Postcoloniality and Feminism. Bloomington and Indianapolis: Indiana University Press.

Nordling, Vanna, Maja Sager, and Emma Söderman. 2017. "From Citizenship to Mobile Commons: Reflections on the Local Struggles of Undocumented Migrants in the City of Malmö, Sweden." Citizenship Studies 21, no. 6: 710-726. 
Peltonen, Salla, and Anna Katarina Jungar. 2018. "The Ascendency of Whiteness: On Understanding Racialized Queerness in LGBTIQ Refugee Work.” In Activism, Research and Pedagogical Praxis: Transnational and Intersectional Perspectives on Gender, Sex, and Race, edited by Tamara Shefer, Jeff Hearn, Kopano Ratele, and Floretta Boonzaier, 57-74. New York: Routledge.

Sager, Maja. 2011. "Everyday Clandestinity." PhD diss., Lund University.

Sager, Maja. 2018. "Struggles Around Representation and In/Visibility in Everyday Migrant Irregularity in Sweden." Nordic Journal of Migration Research 8, no. 3: $175-182$.

van Dooren, Thom. 2014. Flight Ways, Life and Loss at the Edge of Extinction. New York: Columbia University Press.

Varsanyi, Monica. 2006. "Interrogating "Urban Citizenship” vis-à-vis Undocumented Migration.” Citizenship Studies 10, no. 2: 229-249.

Wynter, Sylvia. 2015. "Unparalleled Catastrophe for Our Species?: Or, to Give Humanness a Different Future: Conversations." In On Being Human as Praxis?, edited by Katherine McKittrick, 9-89. Durham and London: Duke University Press. 


\title{
11 Nursing trauma, harvesting data Refugee knowledge and refugee labour in the international humanitarian regime
}

\author{
Nadine Hassouneh and Elisa Pascucci
}

\section{Introduction}

In 2019, in Northern Jordan, in villages not far from the Syrian border that had offered refuge to displaced Syrians for over eight years, a major European humanitarian organization was running an outreach medical programme targeting vulnerable groups. These encompassed pregnant and breastfeeding women, children under five years of age, the elderly, and people with chronic diseases. The community workers in charge of locating and reaching out to beneficiaries included a significant number of Syrian refugees. Unsurprisingly given the nature of the tasks assigned to them, many were women. One of them described the work as follows:

Our work was in the field, we would search for pregnant women, elderly people, and children, we have to work between 9 AM and 3 PM. We were not allowed to leave before $3 \mathrm{PM}$. We were located via GPS from nine till three and not allowed to move elsewhere. [...] We would give pregnant women barcodes, and there was no way of giving a barcode if we were not at the right place, at the pregnant women's homes. We used to take their information, their data, due date, rent, transportation - data collection, then they would receive some help, whether they gave birth naturally or through a C-section. Families with children under five years of age also received some help. Both Jordanians and Syrians - Jordanians without health insurance - would receive 130 Jordanian dinars [...] We had to conduct four visits to four houses every day. We had to search for four pregnant ladies every day, we had to knock on doors.

These words alert us to the fraught data politics of contemporary international aid, whose functioning depends on its ability to collect, store, and circulate information on vulnerable populations. ${ }^{1}$ However, they also pose a radical challenge to the commonly held view of humanitarian aid as provided by wealthy donors and altruistic expatriates from the richest parts of the world, with refugees in the "Global South" on the passive receiving end. People like the Syrian community worker quoted above are part of the large workforce of development and humanitarian organizations, $90 \%$ of which is 
estimated to be composed by people recruited locally - and often precariously or informally - in countries of intervention. ${ }^{2}$ This workforce includes people with a refugee background serving international institutions as researchers, translators, social and community workers, IT technicians, project managers, logisticians, social entrepreneurs, cooks, and cleaners - to name but a few of the forms of labour that sustain the international humanitarian regime. These workers' knowledge of local geographies, languages, social norms, and living conditions is essential for humanitarian aid to be delivered, and indeed for international donors to reach their aid targets. ${ }^{3}$ As the quote above shows, their labour is central to the production of knowledge about the populations that are governed by humanitarian apparatuses.

Refugees' own contributions to international relief efforts have been essential since the early twentieth century. ${ }^{4}$ Yet they are rarely included in accounts of humanitarianism as "care for distant others" following a North-South trajectory. In this chapter we detail the forms of knowledge and labour that people with a refugee background bring to what are known as refugee and humanitarian regimes, namely the assemblages of international laws, institutions, and apparatuses that are tasked with providing protection and assistance to refugees. While rhetorically built upon "Western legal-normative conceptualizations of hospitality" 5 and humanitarian care for vulnerable lives, such apparatuses, we argue, are reproduced by the embodied and localized knowledges of refugees.

Empirically, we focus on data collection, analysis, and logistics tasks performed by displaced Syrian aid workers for international humanitarian organizations and research agencies running medical and psychosocial projects in Jordan. We also offer examples of care and reproductive work performed by Syrian refugees, such as cleaners and psychosocial support group volunteers, for refugee and local communities alike. Highlighting the disregarded cultural and emotional performances such work requires, we move the discussion in this volume beyond academic intellectual production and its historically elitist social politics. In this regard, our aims are in line with those expressed in other chapters, particularly those that foreground and expand the Foucauldian notion of "subjugated knowledge". ${ }^{6}$ Inspired by recent work that has explored the racial politics of humanitarianism, ${ }^{7}$ we foreground the role of the racialization and localization of labour, and of care and embodiment, in keeping these knowledges disregarded.

Our chapter is based on field research on labour in the humanitarian and development sectors carried out in 2016-2019 (Pascucci) and 2019-2020 (Hassouneh and Pascucci). More specifically, it draws on semi-structured interviews with Syrian aid workers conducted in Jordan (in person), Turkey and the UK (remotely) in 2019-2020. Recorded and transcribed in English, this material has been collected mostly in Arabic, and translated by one of the authors (Hassouneh), an Arabic native speaker. In this research, we draw from our previous academic work on the geographies of refugee protection and humanitarian aid (Pascucci) and displacement and diasporas (Hassouneh), as well as on years of professional experience as an analyst and 
consultant in international non-governmental organizations (NGOs), with a focus on the Syrian conflict (Hassouneh).

In the following pages, we start from a review of critical approaches to humanitarianism, aimed at debunking Eurocentric assumptions of "aid to distant others in need", and go through some historical examples of refugee involvement in relief provision since the early 20th century. We then outline our approach to refugees' roles as workers in humanitarian organizations, foregrounding racialization, knowledge, and labour. Subsequently, we analyse interview material on research and data gathering and care work performed by Syrian refugees in Jordan for international NGOs. In conclusion, we reflect on the relation between inequality, justice, and humanitarianism as a form of government of knowledge and care relations in the "Global South".

\section{Beyond helping distant strangers: humanitarianism and refugee knowledges}

Humanitarianism is defined as the ideals and apparatuses that emerged in the twentieth century to alleviate suffering in times of disaster and distress. ${ }^{8}$ As Adia Benton writes, it "is both a set of life-saving interventions and an underlying ethos for action, in which politically neutral - but empathic and compassionate - individuals risk their own lives to save the lives of distant others in distress": 9 conventionally, the narrative is that "professional humanitarians reach out to the vulnerable in times of crisis, and to those who are often marginalized from official mechanisms of justice and remedies for their suffering". Benton ${ }^{10}$ sees coloniality, racialization, and distance from beneficiaries - real and imagined - as constitutive of humanitarian efforts. Similarly, Krista Maxwell ${ }^{11}$ shows how humanitarian imaginaries and practices of relief targeting indigenous population were constitutive of settler colonial regimes in North America. Michael Barnett's ${ }^{12}$ genealogical work also exposes how the history of humanitarianism is tied to that of empire. Barnett and Stein ${ }^{13}$ suggest that the expansion of international aid and assistance in the early and mid-twentieth century mirrored the gradual consolidation of welfare states in the "Global North". This foregrounds humanitarianism as a precarious, arbitrary form of social protection reserved for non-white bodies in the colonized world. ${ }^{14}$

Barnett ${ }^{15}$ considers being "directed at those in other lands" as a defining feature of modern aid. Scholars of biopolitics approach humanitarianism as a technology for the government of vulnerable populations that is essential for "the maintenance of modern (read Western) liberal sovereignty alongside and through the securing of life". ${ }^{16}$ Although based on a more expansive and multi-scalar geographical imaginary, these definitions also maintain that "all humanitarian work contains within it issues of distance". ${ }^{17}$ Drawing on the work of Ilana Feldman and Miriam Ticktin ${ }^{18}$ on the denied selfhood of recipients of humanitarian aid, Polly Pallister-Wilkins ${ }^{19}$ argues that the growing professionalization and managerialism of the sector in the last few decades "historically marks the shift from charitable giving 'at home' to more 
expansive attempts at saving distant strangers": she goes on to state that "the universalised ideals underpinning humanitarian sentiment [necessitate] distance, it requires that the humanitarian subject remains other, as a victim with needs rather than a person with full subjecthood".

These abstract universalized ideals, and their constitutive "distance", are increasingly being challenged in both humanitarian practice and scholarship. Many have argued for the need to be attentive not only to what aid does, but also to how it does it, and through whose labour. ${ }^{20}$ On the ground, the reality of aid provision is made of precarious labour, militarized logistics, fortified architectures, and unequal infrastructures. ${ }^{21}$ Moreover, politicized, activist engagements in relief efforts, ${ }^{22}$ the emergence of alternative geographies of refuge beyond the "Global North" and its legal frameworks, ${ }^{23}$ and the role of southern and refugee actors in the humanitarian arena $^{24}$ are questioning the boundaries of aid, politics, and life with growing urgency. In her work on encounters between established communities of Palestinian refugees in Lebanon and Syrian newcomers, Elena Fiddian-Qasmiyeh ${ }^{25}$ argues that "refugee-led initiatives developed in response to existing and new refugee situations directly challenge widely held (although equally widely contested) assumptions that refugees are passive victims in need of care from outsiders".

These phenomena tend to be conceptualized as external to institutionalized aid actors, rooted in community hospitality (and its discontents), and making up for the failures and voids of an often-dysfunctional international humanitarian regime. In a slight departure from these important bodies of work, we argue here for the relevance of refugee agency and knowledges not only in alternative forms of aid and relief, but also in the functioning and reproduction of established humanitarian apparatuses. In other words, rather than looking at refugee humanitarianism as alternative to the domain of institutional aid, we theorize refugee knowledge and labour as a constitutive, if unacknowledged, element in the modern international humanitarian order. Through their sustained reliance on precarious labour, humanitarianism and refugee aid mimic and intersect with other knowledge production enterprises. In particular, recent research highlights the "increasing interdependence" of the academic and humanitarian aid sectors. ${ }^{26}$

\section{"A (hidden) story of self-help"}

Our argument is rooted in important historical analyses that have shed light on how relief agencies have employed displaced people since what we may term the "pre-history" of the modern refugee regime. ${ }^{27}$ Commenting on the League of Nations' efforts to assist Russian refugees at the end of the World War One, led by the Norwegian polar explorer Fridtjof Nansen, Peter Gatrel1 ${ }^{28}$ highlights how "with no funds at his disposal and only a tiny office" Nansen's agency could hardly provide services and papers to refugees directly. Nansen thus ended up employing displaced Russians as clerks in local branches. "Assisting Russian refugees", Gatrel129 concludes, "became a story of self-help". After the World War Two, the United Nations Relief and 
Works Agency (UNRWA), tasked with providing assistance and relief to Palestinian refugees after the mass displacement of 1948, was employing refugees in its own bureaucracies and services already in its early stages. As Ghada Talhami ${ }^{30}$ has shown, "UNRWA's early large-scale plans for the employment of displaced Palestinians served a primarily political purpose, namely the integration of Palestinians into neighboring countries". ${ }^{31}$ Despite enormous financial and political constraints and widespread contestation by Palestinian communities, UNRWA continued to be a source of employment for refugees until Donald Trump's administration cut its funding in 2018, which left hundreds of workers struggling for livelihoods and pensions. ${ }^{32}$

Through twists, turns, political opportunities, and some recent neoliberal refashioning, the hidden story of humanitarianism as refugee self-help continued through the foundation of the United Nations High Commissioner for Refugees (UNHCR) - the agency that constitutes the institutional pillar of the international refugee and humanitarian regimes - and, with it, well into the twenty-first century. In today's policy domains, refugee self-help is often theorized as community-based governance, "localization agendas" and the economic and social "self-reliance" of refugee communities. ${ }^{33}$ These are seen as "win-win solutions' that put refugees to work in ways that maximise their contribution to host country development" merging "humanitarian and development goals". ${ }^{34}$ Refugees thus become the entrepreneurial protagonists of the social assistance provided to their communities through an increasingly privatized and outsourced aid model. ${ }^{35}$

\section{From universalized ideals to racialized inequalities}

Agendas aimed at transferring responsibilities to local actors and involving refugee communities in implementing humanitarian interventions create opportunities for many. The less explored side to this story of self-help is that of the local and refugee aid workers precariously employed by international aid agencies. Despite the localization and participation rhetoric, humanitarian and development interventions are still mostly funded and planned by a small number of powerful international non-governmental, corporate, and state organizations. ${ }^{36}$ Local and refugee workers are routinely deskilled and confined to low-status, labour-intensive jobs, in which they report to expatriate managers concerned with targets that often have little or no relation to local contexts. ${ }^{37}$ Their conditions in the aid sector have been compared to that of labour in other service industries in poor countries, subject to "'race-to-the-bottom' work arrangements (that) deal indignities to low-paid, highly anxious project-based workers doing repetitive and numbing work for clients in the global North". ${ }^{38}$

Research that has looked into issues of race in refugee aid, and humanitarianism more broadly, can reveal the dynamics and genealogies of this global inequality. ${ }^{39}$ This work has foregrounded race as a social condition that both precedes and frames "the humanitarian encounter", ${ }^{40}$ and critiqued the resilience of the "white saviour complex" and the exploitation of nonwhite bodies in the visual and discursive tropes of contemporary aid. ${ }^{41}$ Lewis 
Turner ${ }^{42}$ has examined the profoundly racialized entrepreneurship and resilience frameworks through which "Levantine" Syrian refugees are constructed as industrious workers, as opposed to the backwardness and passivity attributed to black African displaced people - a phenomenon he describes as "humanitarian anti-blackness" ${ }^{43}$ Bringing together discussions of race and labour, Turner ${ }^{44}$ has exposed the exploitation and inequalities behind framing Syrian refugees' work as a developmental opportunity for host countries, and the relentless promotion of their capacity for self-help within communities and camps. Inspired by these critiques, in the following two sections we examine interview material that shed light on the relation between humanitarianism and racialized labour.

\section{Refugee care and emotional work}

According to the International Labour Organization (ILO), working Syrian refugees in the Irbid governorate in Northern Jordan "took up a large percentage of craft professions as well as sales and services professions inside the host communities". ${ }^{45}$ While they tend to reproduce the cliché of the industrious Levantine refugee so aptly critiqued by Turner ${ }^{46}$ however, ILO reports capture a challenging economic reality. Even after Syrians were able to receive work permits through the so-called "Jordan Compact" of 2016, and despite the genuine integration efforts promoted by staff in many local Jordanian municipalities, informal work prevails, while the public sector remains the main employer for local Jordanians. Patterns of gendered, classed, and racialized employment continue to relegate a large number of Syrian men to sectors like construction and agriculture, where conditions are often the harshest. In this landscape, women often find employment through aid organization programmes recruiting care and psychosocial workers.

When we visited the governorate in early 2020 , as the so-called reconciliation process in Syria advanced and international donor policies towards refugees started to focus more on return, such employment opportunities were becoming scarce. Many major international NGOs had left the area, withdrawing social and financial assistance and essential medical services. Among our Syrian interlocutors, a middle-aged trained nurse recalled the time spent working for UN agencies and a major international NGO. She could not keep her first, demanding full-time job because of health problems. Next, she volunteered for a period, when she was promised formal employment that did not materialize because of the organization's lack of funding. After a short contract as an interviewer-data gatherer, the UN offered her an employment opportunity, conditional upon her availability to move to Amman, the capital, to take a six-week training course. This precarious work trajectory reflects those of many low-status local and refugee aid workers. While going through it, the nurse - who was energetic, skilled, and in dire need of work to support her large family, including adult children and grandchildren - did not shy away from other job opportunities. She worked for two months for the local Jordanian municipality, in a programme co-funded by the ILO, as a 
cleaner in public gardens and parks - one of the many examples of refugees serving local communities through essential, yet underpaid work in the service sector. In order to get that job as cleaner, she often hid her qualifications and degrees. "If people asked me whether I have a degree", she commented, "I would say no. Degrees are of no importance". Her husband and daughter also had no source of income apart from a few occasional jobs at the time of our encounter; like the nurse, they all believed that your connections (wasta in Arabic) get you jobs, whether in international NGOs or in the Jordanian local administration.

Beyond formal qualifications and personal networks, refugee aid workers bring something far more crucial to the humanitarian programmes that employ their labour: intense emotional work and physical presence in an often-dangerous, uncomfortable "field". Expatriate professionals - particularly, but not exclusively, white people from the "Global North" - are often unable to effectively access that field, because of insurance restrictions, lack of language skills, or their own racist prejudices. ${ }^{47}$ Refugee workers, in contrast, know local languages and social norms. This knowledge is essential to the aid machine and keeps these workers in a subaltern position through precarious contracts and "local" salary conditions, often significantly worse than those of expatriate workers. ${ }^{48}$ Yet refugee workers' capacity to be proximate to beneficiaries bridges the gaps between policy and practice, transforming international humanitarianism from a universal idea into actual assistance. For NGOs, international agencies, and donors, refugee and local labour is the only way to reach their targets and carry out their mandate. ${ }^{49}$ For workers from a refugee background, especially women, it is often the only available employment opportunity, limited in time, precarious, and badly paid. In some cases, like that of the Syrian aid worker quoted in the introduction to this chapter, it involves walking across large camps and towns, under the summer sun and through the desert dust, to identify or visit beneficiaries at home. The emotional involvement can also be draining and retraumatizing. Recalling her time spent doing psychosocial work, employed by international NGOs, the Syrian nurse described her renewed exposure to trauma as follows:

Imagine that you are trying to help people in something that you yourself suffer from. Imagine hiding your tears in front of people who are telling you about their losses, which are minimal compared to yours, or with similar losses and fears as yours. I know what they will answer, because I suffer from the same issues. I don't tell them that I am Syrian, to create or maintain a distance. However if I had to, I would say that I am Syrian, but I always hope that people do not end up asking me this question.

These words point to fatigue and exhaustion, but also to a knowledge that is emotional and thus unspoken, embodied, and therefore disqualified. The involvement of refugees as care workers in the international aid and development sector relies on this affective and emotional involvement, as well as on 
individualization and flexibility. ${ }^{50}$ Blurred boundaries between work and the private sphere, it has been argued, characterize humanitarian work across the divide between expatriates and locals. ${ }^{51}$ Yet for refugee workers, personal involvement runs deeper. It exploits moral commitment to one's community, often subsuming emerging political subjectivities into the dull discipline of paid work. In the following passage, another Syrian aid worker, a woman in her twenties, details her motivations for taking up first volunteer and then paid jobs in the refugee aid sector.

When the Arab spring started and arrived in Syria, it felt that our identities as Syrians were restored. Before that, I did not have any meaning in my life or a cause to focus on, but when the Syrian cause started it gave us a goal and identity. I was suddenly proud to be Syrian, seeing people seeking freedom made us proud. [...] I discovered all these local Syrian organizations that work on documentation and accountability and human rights. All the survivors and refugees are asking for justice and accountability.

In this case, personal involvement was not limited to care and emotional work and embodied knowledge. It mobilized the worker's identification as Syrian and her condition as a politicized refugee or exile. Aid and development have been discussed as "anti-politics machines" for at least three decades. ${ }^{52}$ Thus, this trajectory from political awakening to paid work in NGOs is all but surprising. There is much to explore in these experiences of global inequality and alienation. Rather than being erased, refugee workers' political subjectivities and knowledges are recast in these encounters with humanitarian apparatuses. ${ }^{53}$ Far from being a prerogative of intellectual elites, germinal reflection on the condition of exile characterizes the experience of refugees across social divides. ${ }^{54}$ However, the knowledges and knowledge work of refugees with limited access to financial resources and safe international mobility are silenced through exploitative patterns that reproduce racialized inequalities. Before landing a job with satisfactory conditions in an international NGO, a few of our interviewees, all university degree holders, went through experiences that they describe as exploitative and alienating. These were in research projects linked to humanitarian programmes, funded through large international schemes and managed primarily by European academic institutions. In the following section, we go through the intricacies of these refugees' work at the intersection of research and humanitarianism.

\section{Refugee knowledges and the humanitarian-research continuum}

I started working closely with the refugees, with the people in need, with kids, I worked with them for three years and a couple of months. [...] I was planning everything in Jordan, collecting data, doing surveys for the places where we were going to do our humanitarian missions. So [the 
US-based humanitarian organization] came twice a year, for a week-long mission, doing surgeries, treatments, dental clinics, medicine for children and women, general medicine. So I was gathering volunteers and planning and organizing, or getting permissions. I was working in Amman, collecting data, and organized everything before the mission started.

At the time of our encounter, the Syrian man quoted above, an engineering student in his twenties, was working for a relatively small international NGO founded by Syrian expatriates and registered in the UK. We met him in his office, in Amman, where he recalled for us how his career in the humanitarian sector started. It was several years earlier, when he was helping to coordinate the twice-yearly missions of a US-based medical charity. As his words show, such missions, however short and focused, required lengthy preparation in the form of collecting data on the target population. The data were collected by young Syrian refugees with good networks and knowledge of English, like him. Without their work, mostly offered on a volunteer basis, the missions of US-based medics among Syrians in Jordan would have been impossible.

Humanitarianism functions through specific ways of knowing, categorizing, triaging, and socially sorting vulnerable populations, as scholarship has explored in detail..$^{55}$ Professionalization of aid work, stricter insurance requirements for expatriate staff, and extensive reliance on global positioning systems (GPS), biometrics, and other information technologies for remote management make the sector increasingly reliant on data collection and processing. ${ }^{56}$ Much has been written on digital humanitarianism and the knowledges upon which it is founded. Duffield ${ }^{57}$ has theorized this "datafication" of aid as an erasure of the experiences of immersion, linguistic and cultural competency, and capacity to analyse local socio-political dynamics that earlier eras of the international NGO movement had promoted. Here we argue that, rather than erased, these local knowledges have been outsourced, femininized, racialized, and relegated to tasks performed by locally-recruited staff. While they are as essential as ever, today they are disqualified and made invisible. The labour of aid workers with a refugee background, we show, is the backbone of data collection processes and field research tasks that are central to humanitarian programming and donors' policymaking.

Humanitarianism and academic research have much in common, not least because international humanitarian organizations promote and fund research, including academic research. Academic and humanitarian projects also tend to share the same environments, infrastructures, access techniques, and local workforce "in the field" ${ }^{58}$ In the research domain, especially in anthropology and other social sciences, the exploitation of local assistants has a long history. ${ }^{59}$ Today, the number of players on the research field in the "Global South" is much larger, and highly diverse. Biomedical, public health, psychological, engineering, and economics researchers, too, regularly visit refugee camps and settlements. They work with or alongside humanitarian organizations, and employ local staff, including refugees, to collect data. The conditions in which this work is carried out are mostly 
precarious and unequal. ${ }^{60}$ While hyper-mobility is central to career-making in both the aid industry and neoliberal academia, production of knowledge about refugees in both sectors relies on research labour that is kept subordinate through the reproduction of immobility (or constrained mobility) of local assistants and data workers. Many of those we met when conducting research for this chapter referred to their limited access to mobility rights through passports and visas - as a crucial determinant in their precarious working conditions, as well as in their relational construction as racialized subjects. ${ }^{61}$

One of the Syrian university degree holders introduced above shared with us memories of assisting a research project at the interface of the medical, psychological, and social sciences. For it, workers were briefly trained to collect biological samples from refugees, and then sent out to camps to fill in trauma-evaluation questionnaires with refugee youth and children.

We had this questionnaire, so we were asking youth and children about what traumatic events they went through. Because I did not have experience about that, I did not know what impact that would have on me and on them. It was very stressful, especially this questionnaire part. The data sampling was normal, but the questionnaire was very stressful. As data collectors, we were not helping them as humanitarian workers, we were not giving support, we were just collecting data and then let them go without any further support. [...] I think the main impact on me was that I was just listening and recording their stories. I felt like I was exploiting them, I wasn't able to give them anything. That was the most painful. At a psychological level I was very impacted by all the stories, especially the youth and the children we were interviewing, I felt helpless, we could not help them in any way, also after interviewing many mothers, I was alone listening to this, and working alone on this, I think I had secondary trauma.

Like those of many other research assistants recruited to collect data in what Sukarieh and Tannock ${ }^{62}$ have called "the Syrian refugee research industry", this account highlights that for both research subjects and interviewers, this data collection process is labour-intensive and emotionally draining. To be sure, there are differences between extractive data gathering for an academic research project, like the one which involved obtaining biological samples, and surveying populations planned with the purpose of delivering assistance. However, similarities abound. In both cases, the work could simply not be done without refugee assistants. Yet in both instances, the refugee work is precarious in its contractual and insurance conditions, and often remains unacknowledged. For the person interviewed above, this lack of recognition manifested itself in lack of authorship and acknowledgement in the final, published product of the research process - a form of exploitation which is anything but rare, and a division of labour which, across the researchhumanitarian continuum, reproduces colonial relations. ${ }^{63}$ 


\section{Conclusions}

Throughout its history, humanitarianism has been a key way through which modern Europe has come to know, categorize, and extract resources from its colonial others, including refugees. Today, "white saviourism" and the humanitarian gaze are still central to the political self-definition of European and "Global North" legacy powers and their citizen-subjects. ${ }^{64}$ Through them, humanitarianism remains a space where the disqualification and exploitation of refugee knowledges is reproduced and normalized. From its early origins in the relief efforts after the First World War to its late modern neoliberal turns in which subcontracting, privatization, and the "responsibilization" of beneficiaries are ascendant, humanitarian discourse has both appropriated and obscured refugee communities' embodied, caring knowledges and capacities for "self-help" ${ }^{65}$

In this chapter, we have invited you to look at humanitarian aid as a global phenomenon founded on the labour and knowledges of refugees themselves. Refugee aid workers are central to all the stages of humanitarian intervention, from exploratory surveying and preliminary planning to data collection for monitoring and evaluation. Syrian social workers and volunteers nurse the traumas of Syrian refugees. Syrian women working under GPS surveillance identify and classify the vulnerabilities of other Syrian women and their children. Syrian scientific degree holders collect biological samples from refugees in the camps, for research projects funded by European agencies and benefiting mostly European scientists.

Along these internationalized "research supply chains", 66 the tasks assigned to refugee workers are often the most labour-intensive and least prestigious. They require knowledge that is constructed as local and embodied, remains unrecognized, and is underpaid, if not totally unpaid. As emerges from our interviews, there is often no other discernible reason, beyond their being Syrians and being in a refugee condition, for the inequities to which these workers are subjected. In sharp contrast with the transnational mobility that characterizes expatriate aid workers from the "Global North", the immobilization of Syrians through restrictive migration regimes and their construction as workers with local expertise are central to this process of racialization.

Reproducing a division of labour that follows colonial lines, mainstream humanitarian organizations manage knowledge and knowledge production in ways that uphold, rather than question, global racialized inequalities. These divisions and inequalities often go unnoticed, even in critical scholarly literature on humanitarian aid, due to our failure to attend to race and labour as a social dimension that shapes the humanitarian encounter. ${ }^{67}$ The narratives examined in this chapter underscore the relevance of new scholarship that has started to dissect the racialized tropes reproduced by neoliberal aid through its paradigms of refugee self-reliance, entrepreneurship, developmentalism, and community aid. It is essential that this attentiveness to race and labour is applied to social studies of knowledge production, within and 
beyond academia, including those that involve migrants and refugees. The dynamics we have examined here point to the consolidation of global "data value chains", characterized by racialized divisions of labour. ${ }^{68}$ As other contributors to this volume show, "increased competitiveness, pressure by donors and funders to produce 'value for money', and an impetus for original empirical data which requires extensive labour", which are shared by the academic and humanitarian aid sectors, compound these racialized divisions. ${ }^{69}$

For many refugees, employment in humanitarian organizations sustain their family livelihoods, and even bring new skills and knowledges. For the most part, our interviewees did not demand different work in different sectors. Rather, they expected better working conditions, decent compensation and salaries, and to have their hard work in sustaining their communities acknowledged and respected. Similarly, research workers with a refugee background employed in academic contexts need to be empowered "in contractual negotiation and in data stewardship, sharing, and protection". ${ }^{70} \mathrm{Far}$ from being silenced by the inequities they are exposed to, these workers' subjectivities call for a re-evaluation of humanitarianism as liberal government of knowledge, care relations, and social reproduction. This requires a commitment to decolonizing the production of knowledge on refugees, starting with acknowledgment of the essential role their labour plays in humanitarian, care, and knowledge economies.

\section{Acknowledgments}

We wholeheartedly acknowledge and thank Umm Odai, Bana, Umm Ayham, Umm Aya, Umm Nasha'at, Umm Muhammad, Ahmad, Abu Ahmad, Abu Aline, Abu Haidar, and Bilal for all that they generously shared with us. Your contributions were vital to this chapter.

نود أن نقدم خالص شكرنا وتقديرنا لأم عدي وبانا وأم أيهم وأم آية وأم نشأت وأم محمد وأحمد وأبو أحمد وأبو ألين وأبو حيدر

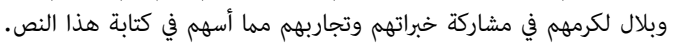

This work has been supported by the Academy of Finland funded Centre of Excellence in Law, Identity and the European Narratives (funding decision numbers 312431 and 336678).

\section{Notes}

1 Duffield, 2018; Lemberg-Pedersen and Haioty, 2020.

2 Ong and Combinido, 2018; Egeland, Harmer, and Stoddard, 2011; Pascucci, 2019.

3 Ward, 2020.

4 Easton-Calabria, 2015; Gatrell, 2017; Fiddian-Qasmiyeh, 2019.

5 Cole, 2020, 1.

6 Rajaram, in this volume.

7 Benton, 2016a; Turner, 2019.

8 Barnett, 2011.

9 Benton, 2016b, 189.

10 Benton, 2016a; Benton, $2016 \mathrm{~b}$. 
11 Maxwell, 2017.

12 Barnett, 2011.

13 Barnett and Stein, 2012.

14 Duffield, 2018; on the colonial and racial origins of the welfare state see also Bhambra and Holmwood, 2017.

15 Barnett, 2011, 21.

16 Pallister-Wilkins, 2018, 3; see also Vernon, 2014.

17 Pallister-Wilkins, 2018, 7.

18 Feldman and Ticktin, 2012.

19 Pallister-Wilkins, 2018, 7.

20 Smirl, 2008.

21 Lopez, Bhungalia, and Newhouse, 2015; Pascucci, 2017; Pascucci, 2019; Smirl, 2008; Ziadah, 2019.

22 Pascucci and Jumbert, 2021; Rozakou, 2017; Vandevoordt, 2019.

23 Cole, 2020.

24 Fiddian-Qasmiyeh, 2016; Fiddian-Qasmiyeh, 2018; Fiddian-Qasmiyeh and Qasmiyeh, 2017; Malkin, 2015; Richey et al., 2021.

25 Fiddian-Qasmiyeh, 2016, 1.

26 Marchais, Bazuzi, and Lameke, 2020, 373; Pascucci, 2017.

27 Easton-Calabria, 2015.

28 Gatrell, 2017, 1.

29 Gatrell, 2017, 1.

30 Talhami, 2003.

31 Talhami, 2003, 139.

32 Fiddian-Qasmiyeh, 2019; see also Farah, 2010.

33 Lenner, 2019.

34 Lenner, 2019, 1.

35 Fiddian-Qasmiyeh, 2019; Turner, 2019.

36 Ong and Combinido, 2018; Fiddian-Qasmiyeh, 2019.

37 Ong and Combinido, 2018; Pascucci, 2019; Ward, 2020.

38 Ong and Combinido, 2018, 90.

39 Benton, 2016a; Benton, 2016b; Ong and Combinido, 2018; Richey, 2016; Turner, 2019.

40 Benton, 2016a, 190.

41 Richey, 2016.

42 Turner, 2019.

43 Turner, 2019, 145.

44 Turner, 2019.

45 ILO, 2016, 29.

46 Turner, 2019.

47 Turner, 2019.

48 Pascucci, 2019.

49 Ward, 2020.

50 Ong and Combinido, 2018; Malkin, 2015.

51 Fechter, 2012.

52 Ferguson, 1990.

53 Kallio, Häkli, and Pascucci, 2019.

54 See the Introduction to this volume.

55 Kallio et al., 2019 and Pallister-Wilkins, 2018 among others.

56 Duffield, 2018; Lemberg-Pedersen and Haioty, 2020.

57 Duffield, 2018. 


\section{Nadine Hassouneh and Elisa Pascucci}

58 Pascucci, 2017.

59 Sukarieh and Tannock, 2019.

60 Sibai et al., 2019; Sukarieh and Tannock, 2019.

61 See Carpio, 2019.

62 Sukarieh and Tannock, 2019.

63 Sukarieh and Tannock, 2019.

64 Richey, 2016.

65 Gatrell, 2017.

66 Desai and Tapscott, 2015.

67 Benton, 2016a; Benton, 2016b; Turner, 2019.

68 Marchais et al., 2020.

69 Marchais et al., 2020.

70 Sibai et al., 2019, 1599.

\section{References}

Barnett, Michael. 2011. Empire of Humanity: A History of Humanitarianism. Ithaca: Cornell University Press.

Barnett, Michael, and Janice Stein. 2012. "Introduction: The Secularization and Sanctification of Humanitarianism." In Sacred Aid: Faith and Humanitarianism, edited by Michael Barnett, and Janice Stein, 3-36. Oxford: Oxford University Press.

Benton, Adia. 2016a. "African Expatriates and Race in the Anthropology of Humanitarianism." Critical African Studies 8, no. 3: 266-277.

Benton, Adia. 2016b. "Risky Business: Race, Nonequivalence and the Humanitarian Politics of Life." Visual Anthropology 29, no. 2: 187-203.

Bhambra, Gurminder K., and John Holmwood. 2017. "Colonialism, Postcolonialism and the Liberal Welfare State." New Political Economy 23, no. 5: 574-587.

Carpio, Genevieve. 2019. Collisions at the Crossroads: How Place and Mobility Make Race. Oakland: University of California Press.

Cole, Georgia. 2020. "Pluralising Geographies of Refuge." Progress in Human Geography 45, no. 1: 88-110.

Desai, Deval, and Rebecca Tapscott. 2015. "Tomayto Tomahto: The Research Supply Chain and the Ethics of Knowledge Production." Humanity Journal. Accessed March7,2021.http://humanityjournal.org/blog/tomayto-tomahto-the-research-supplychain-and-the-ethics-of-knowledge-production/.

Duffield, Mark. 2018. Post-Humanitarianism: Governing Precarity in the Digital World. Cambridge: Polity Press.

Easton-Calabria, Evan. 2015. "From Bottom-up to Top-down: The "Pre-history" of Refugee Livelihoods Assistance from 1919-1979.” Journal of Refugee Studies 23, no. 3: 412-436.

Egeland, Jan, Adele Harmer, and Abby Stoddard. 2011. To Stay and Deliver: Good Practice for Humanitarians in Complex Security Environments. New York: Policy Development and Studies Bureau, UN Office for the Coordination of Humanitarian Affairs (UNOCHA). Accessed May 2020. https://www.unocha.org/sites/dms/ Documents/Stay_and_Deliver.pdf.

Farah, Randa. 2010. "UNRWA: Through the Eyes of its Refugee Employees." Refugee Survey Quarterly 28, no. 2-3: 389-411.

Fechter, Anne-Meike. 2012. "The Personal and the Professional: Aid Workers' Relationships and Values in the Development Process." Third World Quarterly 33, no. 8: 1387-1404. 
Feldman, Ilana, and Miriam Ticktin. 2012. In the Name of Humanity: The Government of Threat and Care. Durham, NC: Duke University Press.

Ferguson, James. 1990. The Anti-Politics Machine: “Development," Depoliticization and Bureaucratic Power in Lesotho. Cambridge: Cambridge University Press.

Fiddian-Qasmiyeh, Elena. 2016. "Refugee-Refugee Relations in Contexts of Overlapping Displacement." International Journal of Urban and Regional Research "The Urban Refugee 'Crisis': Reflections on Cities, Citizenship, and the Displaced" web issue, Accessed September 2016. https://www.ijurr.org/spotlight-on/the-urbanrefugee-crisis-reflections-on-cities-citizenship-and-the-displaced/ refugee-refugee-relations-in-contexts-of-overlapping-displacement/.

Fiddian-Qasmiyeh, Elena. 2018. "Southern-Led Responses to Displacement: Modes of South-South Cooperation?" In Handbook of South-South Relations, edited by Elena Fiddian-Qasmiyeh, and Patricia Daley, 239-255. Oxford: Routledge.

Fiddian-Qasmiyeh, Elena. 2019. "The Changing Faces of UNRWA: From the Global to the Local." Journal of Humanitarian Affairs 1, no. 1: 28-41.

Fiddian-Qasmiyeh, Elena, and Yousif M. Qasmiyeh. 2017. "Refugee Neighbours \& Hostipitality. Exploring The Complexities of Refugee-refugee Humanitarianism." The Critique. Accessed May 2020. http://www.thecritique.com/articles/ refugee-neighbours-hostipitality-2/.

Gatrell, Peter. 2017. "The Nansen Passport: The Innovative Response to the Refugee Crisis that Followed the Russian Revolution." The Conversation. Accessed May 2020.https://theconversation.com/the-nansen-passport-the-innovative-response-tothe-refugee-crisis-that-followed-the-russian-revolution-85487/.

ILO. 2016. Local Economic Development Strategy for Irbid Governorate. Beirut: International Labour Organization (ILO) Regional Office. Accessed May 2020. https:/www.ilo.org/wcmsp5/groups/public/---arabstates/---ro-beirut/documents/ publication/wcms_456503.pdf/.

Kallio, Kirsi Pauliina, Jouni Häkli, and Elisa Pascucci. 2019. "Refugeeness as Political Subjectivity: Experiencing the Humanitarian Border." Environment and Planning C: Politics and Space 37, no. 7: 1258-1276.

Lemberg-Pedersen, Martin, and Eman Haioty. 2020. "Re-assembling the Surveillable Refugee Body in the Era of Data-Craving." Citizenship Studies 24, no. 5: 607-624.

Lenner, Katharina. 2019. "A World of Self-Reliant Refugees? Reflections on World Refugee Day". University of Bath CDS blog. Accessed May 2020. http://blogs.bath. ac.uk/cds/2019/06/20/a-world-of-self-reliant-refugees-reflections-on-world-refugee-day/.

Lopez, Patricia J., Lisa Bhungalia, and Léonie S. Newhouse. 2015. "Introduction: Geographies of Humanitarian Violence." Environment and Planning A: Economy and Space 47: 2232-2239.

Malkin, Noga. 2015. "My Brother's Keeper: The Double Experience of Refugee AidWorkers." Journal of Peacebuilding and Development 10, no. 3: 46-59.

Marchais, Gauthier, Paulin Bazuzi, and Aimable Amani Lameke. 2020. "The Data is Gold, and We are the Gold-Diggers': Whiteness, Race and Contemporary Academic Research in Eastern DRC." Critical African Studies 12, no. 3: 372-394.

Maxwell, Krista. 2017. "Settler Humanitarianism: Healing the Indigenous ChildVictim." Comparative Studies in Society and History 59, no. 4: 974-1007.

Ong, Jonathan Corpus, and Pamela Combinido. 2018. "Local Aid Workers in the Digital Humanitarian Project: Between 'Second Class Citizens' and 'Entrepreneurial Survivors'." Critical Asian Studies 50, no. 1: 86-102.

Pallister-Wilkins, Polly. 2018. "Hotspots and the Geographies of Humanitarianism." Environment and Planning D: Society and Space 38, no. 6: 991-1008. 


\section{Nadine Hassouneh and Elisa Pascucci}

Pascucci, Elisa. 2017. "The Humanitarian Infrastructure and the Question of OverResearch: Reflections on Fieldwork in the Middle Eastern Refugee Crises 20112015." Area 49, no. 2: 249-255.

Pascucci, Elisa. 2019. "The Local Labour Building the International Community: Precarious Work within Humanitarian Spaces." Environment and Planning A: Economy and Space 51, no. 3: 743-760.

Pascucci, Elisa, and Maria Gabrielsen Jumbert. 2021. "Introduction: Citizen Humanitarianism at European Borders." In Citizen Humanitarianism at European Borders, edited by Maria Gabrielsen Jumbert, and Elisa Pascucci, 1-14. Oxon: Routledge.

Richey, Lisa Ann. 2016. “"Tinder Humanitarians": The Moral Panic Around Representations of Old Relationships in the Media." Javnost: The Public 23, no. 4: 398-414.

Richey, Lisa Ann, Line Engbo Gissel, Opportuna L. Kweka, Pernille Bærendtsen, Peter Kragelund, Herbert Qambalo Hambati, and Asubisye Mwamfupe. 2021. "South-South Humanitarianism: The Case of Covid-organics in Tanzania." World Development 141: 105375. doi:10.1016/j.worlddev.2020.105375/.

Rozakou, Katerina. 2017. "Solidarity \#Humanitarianism: The Blurred Boundaries of Humanitarianism in Greece." Etnofoor 29, no. 2: 99-104.

Sibai, Abla M., Anthony Rizk, Adam P. Coutts, Ghinwa Monzer, Adel Daoud, Richard Sullivan, Bayard Roberts, Lokman I. Meho, Fouad M. Fouad, and Jocelyn DeJong. 2019. "North-South Inequities in Research Collaboration in Humanitarian and Conflict Context." The Lancet 394: 1597-1600.

Smirl, Lisa. 2008. "Building the Other, Constructing Ourselves: Spatial Dimensions of International Humanitarian Response." International Political Sociology 2: 236-253.

Sukarieh, Mayssoun, and Stuart Tannock. 2019. "Subcontracting Academia: Alienation, Exploitation and Disillusionment in the UK Overseas Syrian Refugee Research Industry." Antipode 51, no. 2: 664-680.

Talhami, Ghada Hashem. 2003. Palestinian Refugees: Pawns to Political Actors. New York: Nova Science Publisher, Inc.

Turner, Lewis. 2019. “"\#Refugees can be Entrepreneurs Too': Humanitarianism, Race and the Marketing of Syrian Refugees." Review of International Studies 46, no. 1: 137-155.

Vandevoordt, Robin. 2019. "Subversive Humanitarianism: Rethinking Refugee Solidarity through Grass-Roots Initiatives." Refugee Survey Quarterly 38, no. 3: 245-265.

Vernon, James. 2014. Distant Strangers: How Britain Became Modern. Berkeley: University of California Press.

Ward, Patricia. "Capitalising on 'Local Knowledge': The Labour Practices behind Successful Aid Projects - The Case of Jordan." Current Sociology, February 2020. DOI: $10.1177 / 0011392120905342 /$.

Ziadah, Rafeef. 2019. "Circulating Power: Humanitarian Logistics, Militarism and the United Arab Emirates.” Antipode 51, no. 5: 1684-1702. 


\section{Index}

abjection 192

academic: career 5, 6, 22, 110, 114, 116-117, 119-120, 173; culture 3, 95, 109; emotions 114, 123; research 3, 96-97, 207; Western academia 110,121

Academics for Peace 3-5, 8, 136 access to rights 116 acculturation 99, 104, 166 activist 19, 71, 77, 117, 134-135, 202

Adorno, Theodor W. 94, 96

Adra Prison 70

aid workers 12, 182, 200, 203-205, 207, 209

Aleppo Central Prison 70

alienation 156, 167, 186-187, 190-192, 206

al-Khalil, Samira 71

Amnesty International 77

antifascism see fascism

anti-Islamism see Islamism

antisemitism 97-98, 110, 130, 166-167, 173

Arab nationalism 189-190

Arabic 54, 70-73, 81, 185-187, 190, 200, 205; see also culture

Arendt, Hannah 1, 4, 95, 100, 109, $112-113,131,165,170$

artists 105, 146-147, 149, 151, 153-155, 166

assimilation 99, 171-173, 192

asylum 4-5, 11, 26, 54, 56-60, 62-63, 102, 105-106, 110, 128-129, 132-135,

137-142, 153, 183-184, 186-195;

claims 57, 138-139, 184, 186-188, 190-191; seekers 11, 54, 57-59, 62-63, 129, 138, 140, 183-184, 187-190, 192, 194; see also crisis authoritarianism 5, 10-11, 72, 94, $146-148,150,155-158$
Baladna al-Rahib see Our Terrible Country

Barb, Alphons 168

belonging 9, 10-11, 20, 29-32, 38, 63, $114,135,146-148,150,154-155$, 157-158, 167, 170, 183-184, 189, 193-194; alternative models of 194

Bendix, Reinhard 9, 112

Benjamin, Walter 102, 165

Bergsträsser, Arnold 95

Bettelheim, Bruno 174

biography $4-5,9,71,95,97,99-100$, $110,112-114,172$

biopolitics 191, 201

Bleierne Zeit 94

Bloch, Ernst 95

Bodenheimer, Brigitte 5, 112, 171, 174; Edgar 5, 112, 121, 171, 174

border(s) 3, 20-21, 26-29, 32, 53, 57, 60, $62,105,137,147$; cross- 28

Bourdieu, Pierre 54-55, 63, 156

Braidotti, Rosi 10, 154

Brandt, Willy 97

Brecht, Arnold 100, 117

British Society for the Protection of Science and Learning 169

camps: concentration 174; death 104; internment 104; refugee/migrant 29, 57, 59-60, 63, 79, 207-209

capitalism 6, 20, 27, 39-40, 42-47, 49

Cassirer, Ernst 170

Central European University's Open Learning Initiative 48

Chota Nagpore (Chotanagpur) 43, 46

citizenship 9, 26-27, 39, 48, 62, 194-195

civil society $57,146,172$

class 29-31, 39, 47-48, 103, 118, 140, $149,173,190,204$ 
Cold War 55, 94

collective $30,44,57,114,182,184$; action 72 ; biographies 100 ; commitment 94; dimension 150; emergency 187; grieving 11; learning 106; matter of concern 188; memory 93, 106; mobilization 194; narrative 29; practices 30; resistance 10; subjectivity 20,195 ; values/attitudes 154 ; work 97

Colonial India 8, 42-43

colonial(ism) $8,31,38-40,42-46$, 49-50, $58,75,190,201,208-209$; de- 2; post- 28, 39; settler 201

coloniality 40, 201, 208-209; of power $38-40,42$

communism 3, 70, 78, 95-97, 103, 138 community $1,8-9,22,38,40-42,47-50$, $97,99,101,103,116,121-122,130$, 146-148, 150-152, 154-155, 157-158, 169, 183-187, 193, 199-200, 203, 206, 209

Congress for the Defence of Culture see Kongress zur Verteidigung der Kultur Convention Relating to the Status of Refugees 128, 137

cosmopolitanism 9, 28-29, 97, 170

Council for Assisting Refugee

Academics CARA 129, 131, 133, 139

Council of Europe 49, 54, 56, 61

criminalization 184

crisis $54-57,82,137,194,201$; asylum 105; of border control 56; of/in Europe 56, 138; of the European asylum system 56 ; humanitarian 56 , 182 ; identity 115 ; migration/refugee $8,26,40,53,56,60$; talk 57

critical theory 55-56

cultural: inferiority 42 ; others 47 culture $3,20,40,42-43,78,103-104$, $149,154,165,170,184,189-190$; academic 3, 94, 109; American 169; Arab 189; authentic 190; of disbelief 138; emigration 96; émigré 100; European 42; German 170; hegemonic 43; history of 99; of knowledge 98 ; legal 3, 109; majority 150; our/their 189-191; political 3, 93-94, 100; racialised 50; of the West

Germany 96; Western 3 curricula 48, 189

Daube, David 170 death-worlds 76 deportation 60, 75, 103, 174, 193-194 depression 174

Deutsche Forschungsgemeinschaft 97, 101

Deutsche Volksfront 103

diaspora 3, 7, 28, 30, 200

Dickmann, Wilhelm 168

dictatorship 71, 73, 76, 93, 95

discrimination 61,116

displacement $1-5,7,9,70-71,75,79-81$, $83,109-112,114,116-118,121,123$, $147,188,192,200,203$

doctoral: degree/doctorate 22, 117, 172, 174; post- 130; student 10

Dublin Regulation 58

Duhem, Pierre 23

East Germany see German Democratic Republic

economic migrant see migrant

education 2-3, 6, 8, 11, 20, 39-40, 47-49, $61,102,109-110,123,130-131,140$, 143, 147, 171, 176, 186, 191

Ehrhardt, Arnold 175

Einstein, Albert 97, 171

embodiment 10, 30, 80, 182-183, 185, 190-191, 200

emigrant 94, 102-103, 167, 172

emigration and émigré culture see culture

èmigrés 2-4, 93-101, 110-111, 129, 167, 176

Enjailment 70, 77-80, 83

essentialist 2, 27, 31, 55, 80, 155, 189

ethnicity $27,30-31,47,154-155,157$

ethnography 28, 183

Europe 2-4, 8-9, 11, 39-40, 47, 53-56, $61,63,105,117-119,128-129$, 131-132, 138, 184, 194, 209; economy 62; Eurocentrism 7-8, 11, 17, 40, 56, 71, 190, 201; Europeanisation 60; European qualifications 49, 61; institutions 53-55; integration infrastructure 47; legal culture 3, 109; media 56, 58-59, 61; policymaking 54-56, 58, 207; way of life 60

European Agenda on Migration 62

European Commission 40, 57-58, 60-61

European Qualifications Passport for Refugees 61

European Union (EU) 8, 41, 47, 54-55, 57-58, 60-62, 105-106; age-dependency ratio 62; EU Skills Profile Tool 61; EU-Turkey deal 57; Justice and Home Affairs 60; presidency 60 
exile 1-7, 9-12, 26, 42, 70-83, 93-105, 109-112, 114-120, 123, 129-132, 134, 136-137, 141, 146-147, 165-171, 173-175, 182-189, 192, 195, 206; conditions of $79-80,110,112,116$; distinguished 117; experience of 3 , 4-5, 73, 80, 97, 109-111, 112, 114, $123,165-166,183$, 189; home in 183 ; intellectual 2, 117; studies 2-4, 93, 97-98, 102-103, 109

exilement 4, 70, 72-75, 77, 80, 83; exilification 70, 77-80, 83; exiling authority 70, 73-74, 81; exiling political structure $11,73-74,82-83$

experience 1-5, 10, 25, 29, 31, 39-46, 49-50, 53, 55, 59, 61, 63, 70-71, 73, 75-82, 93, 97, 105, 109-116, 120-124, 129-130, 132, 134-137, 141, 148-150, $152,154,156,158,165-168,172$, 182-183, 186, 188-189, 191-192, 194, 200, 206-208; of displacement 2, 4, 109-110, 112, 114; lived 29, 183 externalization $48,50,60$

Fackenheim, Julius 168

fascism 3, 96, 114; anti- 95; Austro- 26; Linksfaschismus 96; see also national socialism

Fasheh, Munir 4

feminization 59, 207

Flechtheim, Ossip K. 95

Fluchtziel Paris 103

forced: disappearance 70-71, 73, 75, 77; see also migration

Foucault, Michel 10, 40-41, 43, 47

Fraenkel, Ernst 95-96

France 24, 102-104, 131

Frankfurt School see The Institute for Social Research

Freedom of expression 146, 151, 154-155

Freire, Paolo 39, 49

Frontex 57

Fulbright 140

gender 29-31, 48, 59, 104, 116, 130, 154, 188-189

German popular front see Deutsche Volksfront

German Research Foundation see Deutsche Forschungsgemeinschaft

Germany 4, 11, 24, 81, 93-98, 100-101, 105, 109, 112-113, 117, 134, 136, 165-174; Democratic Republic (GDR) 95, 97, 101; Federal Republic
94, 96, 98, 100; Nazi 3, 6, 11, 105, 109, 112-113, 134, 165-166; post-war 93; see also Weimar Republic

Gesellschaft für Exilforschung 98 gig economy 129,140

global 2-4, 7-8, 10, 20, 22, 28, 54, 56, $60,63,70,82,104,110,133,146-148$, $150,152,154-155,158,203,206-207$, 209-210; globalization 28-29, 32, 140; Global North 138, 153 , 201-203, 205, 209; Global South 199, 201, 207

governmental 47-49, 56, 76, 149

grief 115, 182-185, 187-189, 192, 194-196

grievability 11, 182, 188-189, 194-195

Gurkhas 46

Habermas, Jürgen 96, 99

Hama massacre 76

Hamadeh, Nazem 71

Hamadeh, Wael 71

Hamish 81

Haraway, Donna 30

harb nafsīa 192

Haymann, Franz 169

hegemony 9 , 38-40, 41, 43, 46, 49-50, $81,146,192$

Herz, John 9, 113-114

Heym, Stefan 95

higher education $2-3,8,11,20,39-40$, $47-48,61,131,140,171$; access to $47-48$

Hintze, Hedwig 174

histoire croisée 104

historical: consciousness 4, 93, 96, 99; experience 40-43, 45-46, 49-50

historicization 105

history of ideas 96, 99, 102

holocaust 93-95, 99-101, 104, 137, 175

home $2-3,5,7,9-10,70,73,77-83,97$, $100,105,111,115,119,122,128$, 131-133, 135, 136, 138-139, 142-143, 146-147, 153-154, 158, 165-166, 171, 173-174, 183-184, 187, 189, 199, 201, 205

home country $4-5,11,78,110,115-119$, 122-123, 130, 134, 136-137, 141, 146-148, 152, 154-158

homophobia 191

Honigswald, Richard 170

Horkheimer, Max 95

hotspot approach 57

human mobility see mobility 
human rights 4-5, 57-58, 110, 114-115, 117-119, 121, 134, 137-138, 146, 148, $188,190,206$

humanitarian(ism) 81, 151, 200-207, 209-210; anti-blackness 204; arena 202; digital humanitarianism (datafication of aid) 207; gaze 209; intervention 203, 209; organizations 7, 60, 199-201, 207, 209, 210; protection 60; racial politics of 200; regimes 7, 12, 199-200, 202-203; work 7, 77, 182, 201, 206, 208

hyper-mobility see mobility

Ichheiser, Gustav 175

'illegal' migration see migration

Illusio 156

immobilization 53, 208-209

inequality $7,28,39,48,50,201$, 203-204, 206, 209

Inland Emigration Bill 43

insecurity $48,61,123,130,134,140-142$, 148, 150, 186-187; see also security

Institut für Zeitgeschichte 97

The Institute for Social Research 96, $110,112,165$

integration 22, 26, 47, 55, 61, 99, 102, $105,111,130,132,136,169,191-192$, 203-204

intellectual history 19, 21, 165

intellectuals see scholars

International Biographical Dictionary of Central European Émigrés 99

International Cities of Refuge Network (ICORN) 11, 147

International Labour Organization (ILO) 204

intersectionality 29-30, 116

irregular migration see migration

Isay, Ernst 169

The Islamic State of Iraq and the Levant (ISIS) 71

Islamism 72; anti- 130

Jahrbuch für Exilforschung 98

Jalpaiguri 43-44, 46

Jay, Martin 96, 165

Jordan 79, 199-201, 207

Jordan Compact 204

justice 4-5, 63, 110, 114, 121, 183, 201, 206

Kaiser Wilhelm 45-46

Kantorowicz: Alfred 95; Ernst 169

Kelsen, Hans 25, 171
Kirchheimer, Otto 5, 94, 171

Kisch, Guido 173

Klein, Richard 168

Knowledge Centre for Migration and Demography (KCMD) 58

knowledge(s): affective 12, 182; alternative 1, 41; alternative ways of knowing 39,41 ; communities of 30 ; cultural 53; dominant 40-41; economy 210; embodied 206; experiential 182; government of 201; grievable 10, 12; localized 200; mobile 1; objective 26; precarious 2; refugee $2,7,11-12,40,42,49,53-55$, 58, 61-63, 195, 199, 202, 206, 209; situated 30; sociological 23; sociology of 96; state or state-centric 40; subjugated 41, 200; transfer 104; work 7, 206

Kongress zur Verteidigung der Kultur 103

König, René 94

Krohn, Claus-Dieter 102

Kuczynski, Jürgen 95

Kuhn, Thomas 104

Kurdistan 132, 137

Labour: colonial, migrant 39, 42-45, 48-49; disposable 39, 44, 47; racialized 204; surplus 44; see also refugee

Lacqueur, Richard 175

language 2, 6, 20-21, 47, 53-54, 57, 58, $79,81,111,116,119-121,123,131$, $133,149,155,165,168-171$, 173-176, 184, 189, 191, 200, 205; skills 53-54, 121, 168, 170, 175-176, 205

League of Nations 202

legal: status 116, 123, 129, 134, 186, 194; see also scholars

Leibholz, Gerhard 170

Levy, Ernst 171-172, 174

Libya 57

Llewellyn, Karl 171

London School of Economics 172

longue durée 101

loss 74, 97, 99, 111, 120, 158, 167-168, 174, 182-185, 190, 192-195, 205; see also grief

Löwenstein, Karl 94

Löwenthal, Richard 95-96

Maghreb 106, 167

Malta Declaration 60

Manhattan Project 99 
Mann, Thomas 97

Mannheim, Karl 25

Marcuse, Herbert 96

marginalization $6,12,42,47-48,70,72$, $75,83,130,166-167,176$; social and economic 47

Martins, Hermínio 21

Mayer, Hans 95

media $2,40,54-59,61,147,149$, $155-156,185,191,194$

Mediterranean 57, 60, 106

mental health 141, 174-175

methodology(ical) 3, 11, 22, 32, 96, 100-101, 104; Eurocentrism 7-8, 11; innovation 99; nationalism 11, 19-22, 24, 26-29, 31-32, 71; pluralism 101; transnationalism 28

Middle East 72, 80, 82, 106, 136, 147 migrant: economic 53; emotions 114 , 122; workers $39,43-44,48-50$; see also labour

migrantization 27

migration: forced 99, 176; 'illegal' 60; irregular 57, 105, 194-195; securitization of 29; studies 19, 22, 28, 31-32, 111,116

Mit dem Gesicht nach Deutschland 97

Mitscherlich, Alexander 94

mobile: methods 28; subjectivity 9; see also knowledge

mobility 1-3, 7, 27, 28, 30, 38, 40, 43-44, 56, 80, 146, 155, 176, 206, 208-209; human $38,40,146$; hyper 208 ; rights 208; transnational 209

modernity 20-21, 28, 38, 44, 46, 72

Morgenthau, Hans J. 100

Mourning 184-185, 190-191, 195

Munich Institute of Contemporary History see Institut für Zeitgeschichte

Nansen, Fridtjof 202

narratives $2,5,7-8,11,20,29,38-40$, $42-46,48,50,53-63,70,76,109$, $112-114,138,146,165,167-168$, $171,174,182-185,187-189,192$, 196, 201, 209; culturalist 46; indigenous 42; of loss 183; on refugees 53 ; subaltern 38 national identity $27,29,105,170$ national socialism 97, 99; see also fascism nationalism 79, 100, 156, 189; ideological 20; new 100; post 22, 26; see also national identity; national socialism; nationality; nation-state nationality 9, 26, 29, 129, 155, 183, 195 nation-state 8, 19-22, 24, 26-29, 31-32, $28,147-148,155,158,189$

necropolitics 73

neoliberal 5-7, 44, 116, 119, 128, 140, 203, 208-209; academia 5, 6, 119, 208

Neumann, Franz L. 100, 111-113, 121, 167,170

New Pact on Migration and Asylum 58

New School for Social Research 99

New Skills Agenda for Europe 61

Nietzsche, Friedrich 93, 105

Nolte, Ernst 99

Nomadic(sm) 9-10, 111, 134, 154-155

non-governmental organization 183, 201

normalization $38,56,99,105,167,183$, 187, 209

North America 6, 133, 201; see also United States of America

Notgemeinschaft deutscher Wissenschaftler im Ausland 172

oblivion $70,73,75-77$

Oraons 43-46

Orientalist (Orientalism) 43-44, 190

other 78, 149, 182-183, 193-195, 200-202, 209; othering 116, 150, 182, 184, 188, 191-192

Our Terrible Country 72, 77

Palestine 4, 82, 202-203

Palmyra or Sednaya military prisons 79

Panofski, Erwin 171

Paris (myth of) 102-104

pedagogy 48-49, 76

permanent position $152,166,172,175$

persecution 3, 6, 102, 110, 116-117, 128, $130,134,137-138,140-142,148,158$, 188

Pew Research Center 60

politicide 74

politics of eternity 70, 73, 75, 83

Popper, Karl 104

positionality $31,113-114,122$

postcolonialism 28, 39 see colonialism posttraumatic stress disorder (PTSD) 134

precarity 1, 2, 4-7, 9-10, 12, 62, 110, $114,121-123,124,140-142,147,154$, 167-168, 176, 182, 192

Pringsheim, Fritz 168-170, 173, 175

Protective association of German writers see Schutzverband deutscher Schriftsteller

Protocol Relating to the Status of Refugees 128

public intellectual 11, 70, 146, 157 
Rabel, Ernst 171

Race 46, 50, 129, 203-204, 209

racial politics of humanitarianism see humanitarianism

racialization 7, 27, 50, 195, 200-201, 203-204, 206-210

racism $61-62,73,138,156,166-167,176$

rape $70,73,75-77$

RefuAid 131

refugee: agency 202; experience 41, 49, 136; identity 121; Jews/Jewish 103-104, 130-131; labour 12, 199; LGBTQI+/queer 182-183, 188; refugee as problem 50,55 ; refugeeness 41-42; scholar 5, 11-12, 112, 128-137, 139-142, 167, 174, 176; scholarship 2, 11-12, 19, 91; studies 8, 19, 26-27, 32; unknown 58; vulnerable 53; see also scholar(s); workers 182, 203, 205-206, 209

religion $26,47,129,156$

remigration 94, 101-102

residual histories 46

resistance $7,10,78,95,146$

retraumatization 205

Rockefeller Foundation 6

Roman law 3, 109, 112, 168, 171

Rusche, Georg 175

safe haven 128, 131, 133, 137

Said, Edward 2, 4, 10

Saleh, Yassin al-Haj 4, 11, 70-83

Schmitthoff, Clive M. 172

scholar(s) 1-6, 9, 11, 19, 21-22, 24-25, $27,31,45,70-72,93,97-98,103$, $105,110,112-113,115-124$, $128-130,133-138,140-142$, 147-148, 150-152, 165-167, 169-171, 173-174, 176; displaced $1-8,11,110-113,169$; émigré 176; exiled 3, 6, 11-12, 109-111, 114, 132, 137, 165-167, 171, 175; female 173-174; German-Jewish 3, 109, 112 , 175 ; identity $5,11,91,110,114$, 116-117, 119, 121-122; knowledge 11; legacy 93-94; legal 109-113, 114, 116, 167-168, 170, 172, 175; (e)migration 22, 32, 97, 99, 114; nomadic 10; non-Western 136; precarious (precarity of) 6-7; refugee 5-7, 11-12, 111, 128-142, 167, 174, 176; at Risk (SAR) 3, 7, 11, 147; Scholar Rescue Fund (SRF) 129, 147; Turkish 6; visiting 6-7; vulnerable 11; Western 1 scholarship 2-4, 6-7, 10-12, 19, 21-22, 47, 101, 109, 111-113, 117, 131, 135-137, 165-167, 175, 202, 207, 209

Schulz, Fritz 112, 168-170, 173-174

Schutzverband deutscher Schriftsteller 103

sectarianism 71-73, 83

security $60,81,123,128,134,140$, 146-147, 150, 156, 173, 182-183, 193; border 53; Council 81; discourse 60; in- $48,61,123,130,134,140-142$, 148, 150, 186-187; internal 59;

national 59; place of 62 ; question 59; risk(s) 40, 138; social 27, 154; threat 41, 55, 60-61, 138; see also insecurity securitization 59,81 ; discourse 60 ; of migration 29

self-reflectivity 136

sexual identity 184, 188-189, 191

Silbermann, Alphons 94

situatedness 5, 8, 31, 116

Smith, Anthony D. 22

space(s): in between 194; of exception 75

Staatswissenschaft 94

stable concepts $38,41,43,46,49-50$

state-nation-community $8,38,40-42$, $47-50$

state recognition 183-186

stigmatization 95,188

Strategic Committee for Immigration, Frontiers and Asylum (SCIFA) 60

Strauss, Herbert A. 98

Strauss, Leo 101

structural: marginalization 176; sexism 174

subaltern: others 8, 39-40; position 205 subjugation 42

suicide 114, 165, 174-175, 187, 192

super-diversity 62

suspended life 79

Syria 4, 12, 70-83, 119-121, 131-132, 135-136, 138-139, 187, 199-202, 204-209; Assadist Syrian state 75; Syrian Communist Party 71; Syrian Muslim Brotherhood 76; Syrian refugee research industry 208; Syrian Revolution 70-71, 73-74, 82-83

Tadmor prison 70

temporariness 141

terrorism 60-61

Thana Bhagat movement 46

Tillich, Paul 4, 112

transdisciplinarity 104

translocations 30 
transnationalism 20, 26-28, 30, 32, 54, $62,147,155,209$; transnational citizenship 26; transnational mobility; see also mobility

trauma 12, 166-167, 174-175, 182, 187, 199, 205, 208-209; see also posttraumatic stress disorder; retraumatization

travaux préparatoires 54

Turkey 3, 5-6, 8, 57, 71, 79-82, 119, 132, 136-137, 173, 188, 200

UK University and College Union 141

UN Refugee Convention 58

unassimilable difference 185,188

uncertainty $10-11,77,80,115,119,141$, $146-150,152-156,158$

United Nations 81, 155

United Nations High Commissioner for Refugees (UNHCR) 11, 188, 203

United Nations Relief and Works Agency (UNRWA) 203

United States of America 3-4, 24, 26, $82,94,96,102,165,170$

university $2,6-7,22,39,47-48,50$, 94-95, 101, 110-111, 116-117, 121, 130-132, 135, 140-141, 149-150, 152-153, 169-171, 172, 175, 184, 206, 208; in Exile 6

US Emergency Committee in Aid of Displaced Foreign Scholars 169 value-derogation 42

Voegelin, Eric 19, 21-27, 95

von der Leyen, Ursula 60

von Neumann, Klára Dán 175

Vormeier, Barbara 102

vulnerable objects 55; see also scholar(s), refugees

Weber, Max 24-25

Weimar Republic 102

Weiss, Peter 101

West Germany see Federal Republic

white saviourism 203, 209

Wiggershaus, Rolf 96

Williams, Raymond 40-41, 43, 46-47, 49

Willkommenskultur 105

Wirtschaftswunder 95

Wissenschaftsemigration 98

Wolff, Hans Julius 172

Wolff, Martin 172

Wolffheim, Nelly 173

Writers 103, 146-147, 149, 151, 154-155, 166

Zamindari 45-46

Zeitouneh, Razan 71

Zentrum für Antisemitismusforschung 98

Zilsel, Edgar 175

Zuckmayer, Carl 169

Zwillinger, Emmy 173 